\title{
DINÂMICA DA COBERTURA PEDOLÓGICA DE UMA ÁREA CRATÔNICA DO SUL DE MINAS GERAIS
}

\author{
ALEXANDRE CHRISTÓFARO SILVA
}

Tese apresentada à Escola Superior de Agricultura "Luiz de Queiróz", Universidade de São Paulo, para a obtenção do Título de Doutor em Agronomia, Área de Concentração: Solos e Nutrição de Plantas.

PIRACICABA

Estado de São Paulo - Brasil

Novembro - 1997 
Silva, Alexandre Christófaro

Dinâmica da cobertura pedológica de uma área cratônica do Sul de Minas Gerais / Alexandre Christófaro Silva. - - Piracicaba, 1997.

191p. : il.

Tese (doutorado) - - Escola Superior de Agricultura Luíz de Queiróz, 1997. Bibliografia.

1.Formação do Solo 2. Latossolo húmico 3. Morfologia do solo 4. Pedologia 5. Relação solo-paisagem. I. Tíulo

CDD 631.44 


\title{
DINÂMICA DA COBERTURA PEDOLÓGICA DE UMA ÁREA CRATÔNICA DO SUL DE MINAS GERAIS
}

\author{
ALEXANDRE CHRISTÓFARO SILVA
}

Engenheiro Agrônomo

Orientador: Prof. Dr. PABLO VIDAL TORRADO

Tese apresentada à Escola Superior de Agricultura "Luíz de Queiróz", Universidade de São Paulo, para a obtenção do Título de Doutor em Agronomia, Área de Concentração:

Solos e Nutrição de Plantas.

PIRACICABA

Estado de São Paulo - Brasil

Novembro - 1997 


\section{DINÂMICA DA COBERTURA PEDOLÓGICA DE UMA ÁREA CRATÔNICA DO SUL DE MINAS GERAIS}

ALEXANDRE CHRISTÓFARO SILVA

Aprovada em:

Comissão julgadora:

Prof. Dr. Arary Marconi

ESALQ/USP

Prof. Dr. Pablo Vidal Torrado

ESALQ/USP

Prof. Dr. Celso Augusto Clemente

ESALQ/USP

Prof. Dr. Felipe Macias

USC/Santiago de Compostela-Espanha

Prof. Dr. Antônio José Ranalli Nardy UNESP/Rio Claro

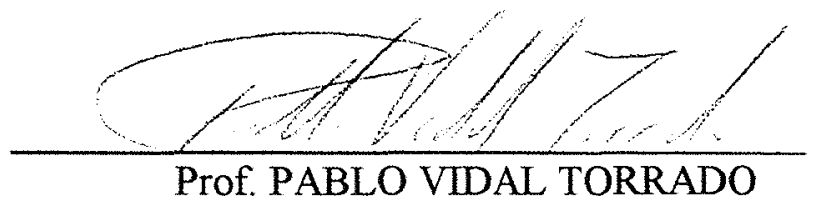

Orientador 
DEDICATÓRIA

À minha mulher Rosana, aos meus filhos Túlio e Bárbara e às montanhas de Minas Gerais, dedico 


\section{AGRADECIMENTOS}

À Coordenadoria de Aperfeiçoamento de Pessoal de Nível Superior (CAPES), através do Programa de Incentivo a Capacitação de Docentes e Técnicos (PICDT), pela concessão de bolsa de estudos.

À Escola Superior de Agricultura "Luíz de Queiróz", da Universidade de São Paulo, pela oportunidade de cursar um doutorado de excelente nível.

À Universidade de Alfenas (UNIFENAS), em especial ao Pró-Reitor Hudson Carvalho Bianchini, pela liberação e pelo apoio dado para a realização deste curso.

À Fundação de Apoio a Pesquisa do Estado de Minas Gerais (FAPEMIG), pelo financiamento do projeto do qual derivou esta tese.

Ao Prof. Dr. Pablo Vidal Torrado, grande orientador e amigo, o alicerce amplo e irrestrito deste trabalho.

Ao Prof. Dr. Allaouá Saadi, pelo apoio dado nos trabalhos de campo e de escritório e pelas imprescindíveis informações dadas como co-orientador voluntário.

À geóloga M. Sc. Marcilene dos Santos, pelo apoio dado na confeç̧ão do mapa estrutural da área deste estudo.

Aos estagiários Yara Maria de Ávila e Fabiano Andrei Bender da Cruz, pelo auxilio em diversas etapas desta pesquisa.

Ao Prof. Edson Antônio Velano, Reitor da UNIFENAS, e ao Diretor da Gráfica Atenas Nilo Alexandre Fonseca, pela impressão desta tese.

Por fim, um agradecimento especial ao Técnico em Laboratório e Tecnólogo em Processamento de Dados Luíz Roberto de Paiva, um grande amigo, cuja atuação em todas as etapas deste trabalho foi fundamental para alcançar este resultado final. 


\section{SUMÁRIO}

Página

LISTA DE FIGURAS............................................................................ ix

LISTA DE TABELAS .......................................................................... xiv

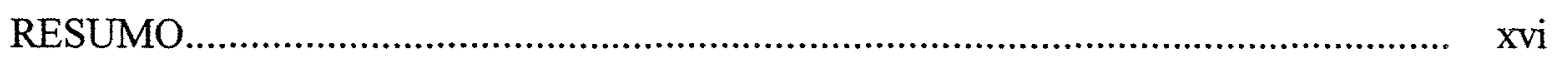

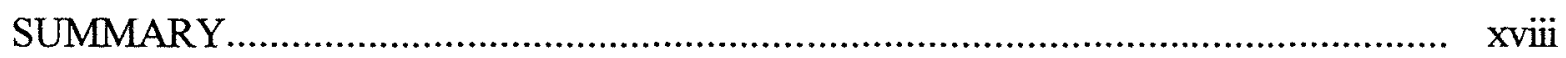

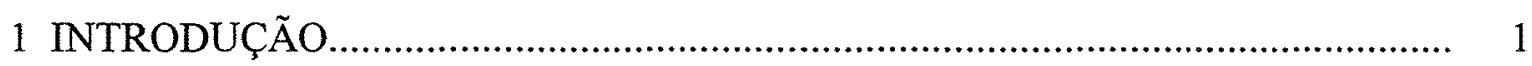

2 REVISÃO DE LITERATURA ................................................................. 4

2.1 A necessidade de abordagem multidisciplinar em estudos de relações entre solos e

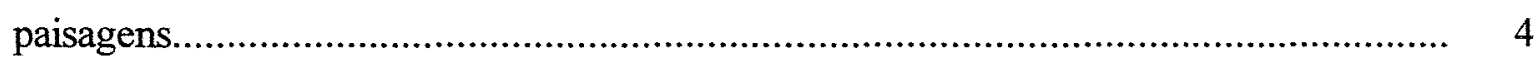

2.2 Modelos de evolução do relevo............................................................. 7

2.3 Considerações a respeito da geologia do Sul de Minas Gerais.......................... 14

2.4 Evolução do relevo no Sul de Minas Gerais................................................. 16

2.5 Crátons, faixas móveis e falhas geológicas.................................................. 23

2.6 Influência da neotectônica na evolução da paisagem....................................... 26

2.7 Questões de pedogênese em áreas cratônicas do Pré-Cambriano.......................... 30

2.7.1 Gênese de latossolos......................................................................... 30

2.7.2 Latossolos Húmicos.......................................................................... 36

2.7.3 Latossolos em relevo movimentado.................................................... 39

2.7.4 Ação da fauna do solo na gênese de latossolos.......................................... 41

2.7.5 Gênese dos podzólicos............................................................................ 44

2.7.6 Transição entre solos com Bw para solos com Bt...................................... 46

2.7.7 Linhas de pedra ("stone lines") e descontinuidades litológicas.......................... 46 


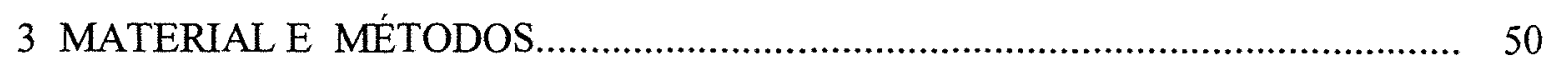

3.1 Caracterização do meio fisico....................................................................... $\quad 50$

3.1.1 Localização...................................................................................... $\quad 50$

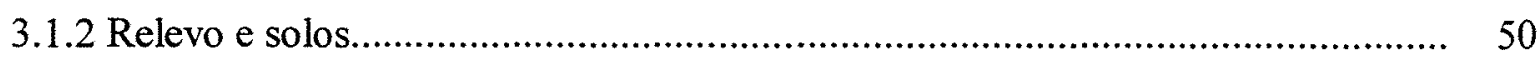

3.1.3 Vegetação e clima.......................................................................................... 53

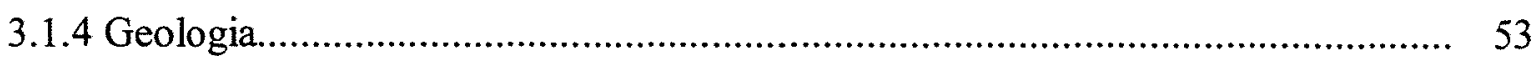

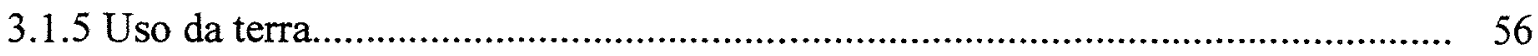

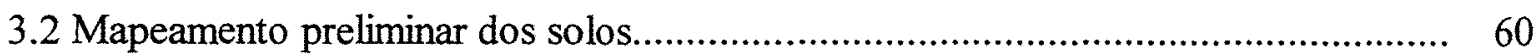

3.3 Mapeamento geomorfológico e identificação das feições tectônicas........................ 60

3.4 Mapeamento geológico..................................................................................... 62

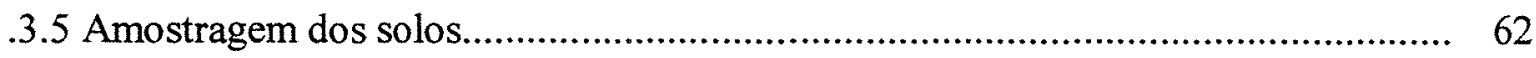

3.6 Morfologia dos solos (Pedografia) …............................................................ 62

3.7 Identificação de solos originados a partir de diferentes materiais e de descontinuidades litológicas em profundidade............................................................ 63

3.8 Análise das amostras de terra......................................................................... 64

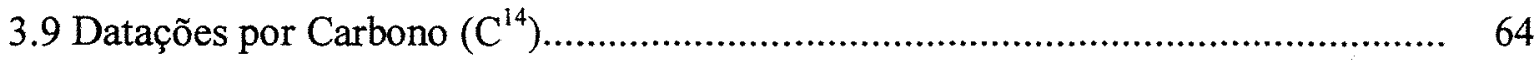

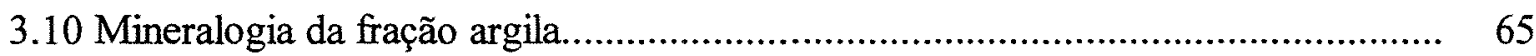

3.11 Mapeamento semi-detalhado dos solos........................................................ 65

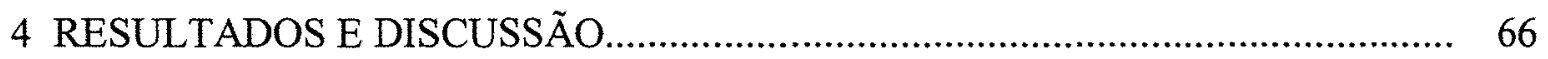

4.1 Quadro estrutural e tectônico regional............................................................... 66

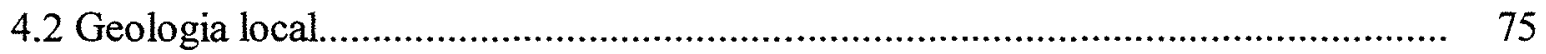

4.3 Geomorfologia e evolução do relevo............................................................ 80

4.3.1 Descrição do relevo regional............................................................................. $\quad 80$

4.3.2 Modelo de evolução do relevo.................................................................. 82

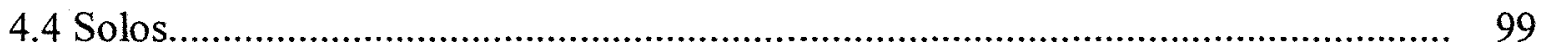

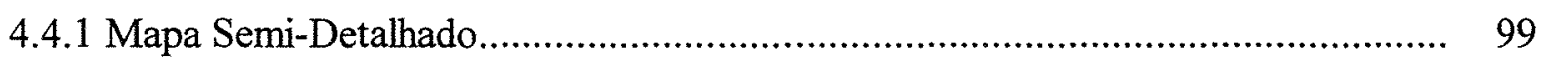

4.4.2 Morfologia dos solos (Pedografia) ............................................................. 102

4.4.2.1 Sistema Morfopedológico I (SMI) ......................................................... 102

4.4.2.2 Sistema Morfopedológico II (SMII) _........................................................ 134

4.5 Gênese do horizonte A húmico....................................................................... 148 
4.6 Evolução cronológica da paisagem e dos solos................................................... 161

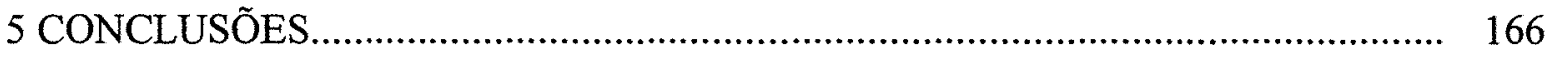

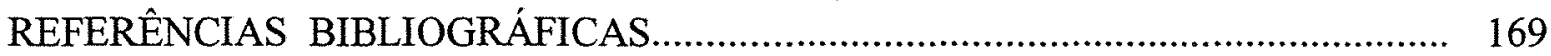

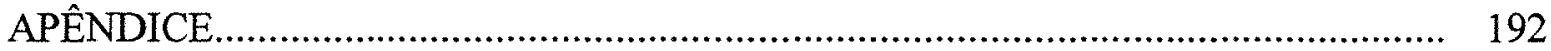




\section{LISTA DE FIGURAS}

Página

1 Principais modelos de evolução do relevo: a) Davis: decréscimo progressivo do relevo. b) Penck: reposição sucessiva do processo erosivo. c e d) King: recuo paralelo de vertentes, sendo em c) com escarpa e em d) sem escarpa. e) Ruhe: recuo de vertentes em fase gradacional com maior retirada de material nas partes mais altas. f) Hack: equilibrio dinâmico da paisagem sem alteração da forma do relevo. Fonte: Vidal Torrado (1994)

2 Representação de uma área localizada no escudo cristalino do sudeste do Brasil antes e depois de mudanças climáticas envolvendo clima úmido (fases I e III ) e clima semi árido (fase II). Adaptado de Lepsch et al. (1986)

3 Localização da área dos estudos.

4 Bloco diagrama da área estudada. (A) Vista frontal. (B) Vista lateral. Área representada pelo Sistema Morfopedológico I. (2) Área representada pelo Sistema Morfopedológico II

5 Sistema Morfopedológico I (SMI) .......................................................... 54

6 Sistema Morfopedológico II (SMII) ............................................................ 55

7 Representação esquemática da Cunha de Guaxupé......................................... 57

8 Tectônica transcorrente no Sul de Minas Gerais.......................................... 58 
9 Cristas de orientação circular na região dos estudos....................................... 59

10 Vista parcial do Sistema Morfopedológico I. Cafezais e pastagens dominam a paisagem. Detalhe: escarpa na parte central da imagem

11 Sistema MorfopedológicoII observado a partir do Sistema MorfopedológicoI. Áreas utilizadas com pastagens, cafezais e culturas anuais.

12 Zonas sismogênicas do Sul de Minas Gerais.

13 Sequência de falhas no regolito de um Latossolo Vermelho-Escuro, exposto nos dois lados de um corte de estrada da MG-179. Escala de 1:450

14 Espelho de falha a) no saprolito e b) no solum de Latossolo Vermelho Escuro. 70

15 Fotomicrografia do horizonte $\mathrm{AB}$ de $\mathrm{P} 1$. Poros fissurais orientados preferencialmente na direção SE-NW. Aumento de 28x.

16 Fotomicrografia do espelho de falha em saprolito. a) luz polarizada; b) luz incidente. Detalhe de um drag na parte central da imagem. Aumento de $28 \mathrm{x}$

17 Distribuição estatística das areias no espelho de falha e no material adjacente. 73

18 Vista parcial do sopé trapezoidal no front de SMI....................................... 75

19 Mapa geológico obtido por fotointerpretação................................................... 76

20 Mapa geológico da área estudada............................................................. 77

21 Mapa geomorfológico da área estudada....................................................... 81

22 Linha de pedras de origem residual no SMI. Setas indicam o grau de filiação e a orientação dos fragmentos de gnaisse ferruginizado.......................................

23 Teores de Tỉ e Fe de P1 (A), P2 (B), P3 (C), relação Ti/Zr do horizonte Bw de P1, P2 e P3 (D) e variação da relação Ti/Zr em SMI (E) 
24 Fotomicrografia do horizonte $\mathrm{Bw}$ de $\mathrm{P} 3$, mostrando adensamento do plasma em Latossolo Vermelho Amarelo Húmico caulinítico-gibbsítico. Aumento de $28 \mathrm{x}$

25 Esquema simplificado do transporte a curta distância do regolito, na encosta SW do SMI, a partir do Mioceno Médio

26 Esquema simplificado da formação de topos com latossolo húmico no SMII, a partir do Plioceno

27 Teores de Ti e Fe (A); teores de $\mathrm{Zr}$ (B) e relação Ti/Zr (C) dos solos de SMII.

28 Distribuição estatística das areias nos horizontes $\mathrm{A}$ e Bw dos solos que formam a cobertura pedológica de SMII, desde o topo até a várzea................ 96

29 Vista parcial do A)anfiteatro suspenso e B) Depressão semi-fechada.

30 Mapa pedológico Semi-Detalhado da área estudada

31 Esquema dos diferentes tipos de agregados que ocorrem nos latossolos da área estudada

32 Fotomicrografia do horizonte Ap de P1. Trama grânica-granóidica. Aumento de $28 x$

33 Fotomicrografia do horizonte A2 de P1. Adensamento do plasma próximo as paredes dos biopedotúbulos com poros fissurais na direção SE-NW. Aumento de $28 x$

34 Fotomicrografia do horizonte Bw2 de Extra 64. Trama grânica granóidica e porfirítica. Aumento de $28 \mathrm{x}$

35 Arranjo dos biopedotúbulos e cor dos horizontes do perfil P2 (Latossolo Vermelho Amarelo Húmico)

36 Fotomicrografia do horizonte Ap de P2. Trama grânica. Aumento de $28 \mathrm{x}$ 
37 Fotomicrografia do horizonte $\mathrm{Bw}$ de P2. Trama grânica-granóidica e porfiritica.Aumento de $28 \mathrm{x}$.

38 Fotomicrografia sob luz polarizada do horizonte Ap de P4. Aumento de $28 \mathrm{x}$.

39 Fotomicrografia do horizonte Bw de $\mathrm{P} 4$. Canal parcialmente preenchido com plasma descolorido e coprólitos. Aumento de 28x.

40 Fotomicrografia da transição $\mathrm{A} / \mathrm{AB}$ de $\mathrm{P} 6$. Trama porfirítica. Aumento de $28 \mathrm{x}$

41 Fotomicrografia do horizonte Bt de P6. Ferriargilãs nas paredes da cavidade, argilãs entre os agregados e descolorimento do plasma. Aumento de $28 \mathrm{x}$

42 Fotomicrografia do horizonte $\mathrm{Bt} 2$ de P6. Trama granóidica. Aumento de $28 \mathrm{x}$

43 Fotomicrografia do horizonte Ap de P7. Trama porfirítica. Aumento de $28 \mathrm{x}$

44 Fotomicrografia sob luz polarizada da transição BA/Bt em P7. Predomínio de cutãs de iluviação. Aumento de $28 x$

45 Detalhe dos cutãs de iluviação ( argilãs e ferriargilãs ) nas paredes de uma cavidade na transição BAlBt. Aumento de 104x.

46 Fotomicrografia do horizonte Bt1 de P7. Trama granóidica. Aumento de 28x..

47 Fotomicrografia do horizonte Ap de P9. Trama granóidica. Aumento de 28x...

48 Teores de Ti, Fe e Zr em P9 (A), P10 (B) e relação Ti/Zr em P9, P10 e P12 (C)

49 Fotomicrografia do horizonte Bw de P10. Trama grânica-granóidica. Aumento de $28 \mathrm{x}$ 
50 Detalhe do carvão se decompondo no horizonte Ap de P9. As partes brunadas do plasma contrastam com as cores dominantes. Aumento de $208 x$.

51 Fotomicrografia do horizonte Ap de P11. Trama porfirítica. Aumento de 28x..

52 Fotomicrografia do horizonte $\mathrm{Bw}$ de P11. Trama granóidica. Aumento de $28 \mathrm{x}$

53 Fotomicrografia do horizonte Bw de P12. Trama granóidica e porfirítica. Aumento de $28 \mathrm{x}$

54 Distribuição da matéria orgânica com a profundidade dos perfis da encosta SW de SMI

55 Distribuição da matéria orgânica com a profundidade dos perfis: A) encosta NE de SMI; B) de SMII.

56 Perfil de distribuição de carvão com a profundidade em Latossolo Húmico de SMI (P3) e de SMII (P10).

57 Fotomicrografia do horizonte Ap de P10. Trama granóidica e porfirítica. Presença de agregados vermelhos e arredondados. Aumento de $28 \mathrm{x}$.

58 Fotomicrografia do horizonte Bwl do perfil Extra 64. Agregados que preechem os biopedotúbulos apresentam cores brunadas. Aumento de $28 \mathrm{x}$

59 Fotomicrografia do horizonte A2 de P2 sob luz incidente (A) e sob luz polarizada (B). Microagregado de $2 \mathrm{~mm}$ de diâmetro se fragmentando em outros menores. Aumento de $28 \mathrm{x}$

60 Decomposição do carvão no horizonte $\mathrm{AB}$ de $\mathrm{P} 2$, originando material plásmico de coloração brunada ou bruno avermelhada. Aumento de $208 x$ 
61 Fotomicrografia do horizonte $\mathrm{AB}$ de $\mathrm{P} 2$. Cores avermelhadas aparecem na periferia de fragmentos de carvão (A) e se intensificam sob luz polarizada (B).

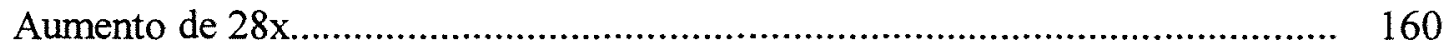

62 Fotomicrografia do horizonte $\mathrm{Bw}$ de P12. Raíz em decomposição com cores avermelhadas, brunadas e pretas. Aumento de 208x......................................... 161

63 Sequência de evolução do relevo ao longo do tempo geológico......................... 163 


\section{LISTA DE TABELAS}

Página

1 Resultados das análises granulométricas, da capacidade de troca de cátions (CTC), da soma de bases (S), da saturação por bases (V) e saturação por alumínio (m) das amostras coletadas no espelho da falha geológica e no saprolito ao lado da falha.

2 Resultados da análise granulométrica e do teor de $\mathrm{Fe}$ total e Ti total dos diferentes saprolitos encontrados no SMI

3 Datação do carvão do solo, coletado a diferentes profundidades em dois perfis de Latossolo Húmico, pelo método do $\mathrm{C}^{14}$ 


\title{
DINÂMICA DA COBERTURA PEDOLÓGICA DE UMA ÁREA CRATÔNICA DO SUL DE MINAS GERAIS
}

\author{
Autor: ALEXANDRE CHRISTÓFARO SILVA \\ Orientador: Prof. PABLO VIDAL TORRADO
}

\section{RESUMO}

Em uma área de 5.750ha situada no segmento central do Sul de Minas Gerais, entre os municípios de Machado e Alfenas realizou-se um estudo integrando-se informações de caráter geológico, geomorfológico e pedológico, com o intuito de interpretar a pedogênese e a distribuição dos solos na paisagem. Enfatizou-se a influência da tectônica na formação do relevo e na distribuição dos solos, a gênese dos latossolos húmicos, a origem do horizonte microgranular e do $\mathrm{B}$ textural, a formação de linha de pedras e a distribuição de solos com horizonte $\mathrm{Bw}$ ao longo das vertentes. Mapeou-se a geologia, a geomorfologia (identificando-se as feições tectônicas) e os solos. Dois sistemas morfopedológicos (SMI e SMII) foram escolhidos para o detalhamento dos estudos, por serem representativos dos dois principais compartimentos geomorfopedológicos da região: a superficie dissecada de topografia montanhosa e a superficie rebaixada de patamares colinosos. Análise estrutural, estudos analíticos (químicos, mineralógicos, fisicos e datação por $\mathrm{C}^{14}$ ), morfológicos e micromorfológicos foram realizados nestes sistemas. A gênese e a distribuição dos solos na paisagem do SMI foram grandemente influenciadas pela ação da tectônica ressurgente. A reativação 
de falhas provocou o basculamento de blocos, induzindo os movimentos de massa e o reafeiçoamento do relevo. Feições geomorfológicas e espelhos de falha estão entre as evidências desta reativação. Topos com afloramentos de rochas félsicas, soleiras, anfiteatros suspensos e escarpas foram identificados como marcas do controle estrutural na conformação da paisagem do SMI. A erosão hídrica é o principal processo responsável pelo esculpimento do relevo em SMII. O aumento do teor de areia da posição de topo para o sopé, a discrepante distribuição de areias entre os solos do topo e os de meia-encosta e sopé e a relação entre cores dos horizontes dos solos nas diferentes posições da encosta estão entre os parâmetros que evidenciam o transporte hídrico. A origem residual da linha de pedras foi demonstrada pela sua forma de ocorrência, pela distribuição, pela pobre seleção e pelo elevada relação de filiação entre os fragmentos de gnaisse ferruginizado. A origem dos microagregados dos latossolos foi atribuída a 4 processos: zoogênese, geoquímica, estruturação e complexação. Os microagregados zoogenéticos são ovais, escuros e brilhantes, apresentam esqueleto interno triado e são os mais abundantes. Os microagregados de origem geoquímica podem ter sido formados pela desferrificação parcial resultante da transformação de goethita em hematita. A estruturação e a complexação têm menor função na microagregação. $O$ horizonte húmico foi formado pela melanização e mantido pelas ligações humus-argila estáveis. A adição, a transformação e a translocação de materiais no perfil do solo pela ação da fauna do solo (constatada pelo aumento da idade do carvão com profundidade) provoca o escurescimento dos microagregados e o espessamento do horizonte húmico. A decomposição do carvão também contribui para a melanização do horizonte húmico. Os latossolos húmicos foram considerados paleossolos e se constituíram em um elo fundamental para o entendimento da dinâmica da paisagem. $O$ estabelecimento do modelo de evolução da paisagem só foi possível integrando-se informações de caráter geológico, geomorfológico e pedológico. 


\title{
DYNAMICS OF A PEDOLOGICAL CONVERING OF A CRATONIC AREA IN THE SOUTH OF MINAS GERAIS
}

\author{
Author: ALEXANDRE CHRISTÓFARO SILVA \\ Adviser: Prof. PABLO VIDAL TORRADO
}

\section{SUMMARY}

A geological, geomorphological and pedological study was carried out in a 5,750 ha. area situated in the central segment of South Minas Gerais, between the cities of Machado and Alfenas, with the pourpose of explaining the pedogenesis and distribuition of soils in the landscape. Enfasis were giving for influence of tectonics on reilief formation and soil distribuition, genesis of humic oxisol, origin of microgranular and argilic horizon, formation of the stone line, and distribuition of soils with horizon $\mathrm{Bw}$ along the slopes. The geology, geomorphology (identifying the tectonic shaping), and the soils were mapped. Two morphopedological systems (MSI and MSII) were chosen for the particulars of the study, for being representative of the two main geomorphopedological compartments of the region: the dissected surface of mountainous topography and the lowered surface of hilly plateaus. The structural analysis, and analytical (chemical, mineralogical, physical, and $\mathrm{C}^{14}$ dating), morphological and micromorphological studies were performed in these systems. The genesis and distribuition of soils in MSI landscap were largely influenced by the action of the 
resurgent tectonics. The reactivation of faults caused the tipping of blocks, inducing mass movements and relief reshaping. Geomorphological shapings and fault mirrors are among the evidences of this reactivation. Tops with outcropping of felsic rocks, sills, suspended amphiteaters, and scarps were identified as marks of the structural control and the conformation of the MSI landscap. Hidric erosion, is the main process responsible for shaping of the rielef in MSII. The increase in sand contents from top of foot, the discrepant distribution of sands between the soils of the top and those of half-hillside and foot, and the relation between colors of soils horizons at different positions of the hillside are parameters with confirm hidric transport. The residual origin fo the stone line was demonstrated by its form of occurrence, distribution poor selection and high filiation relationship between the fragments of ferrugineous gneiss. The origin of the microaggregates of the oxisols was attributed to four processes: zoogenesis, geochemistry, estructuration and complexation. Ovoid, dark and shining, the zoogentic microagregates exhibt a triad internal eskeleton and are the most abundant. The microagregates of geochemical origin may have been formed by the partial deferrification resulting from the transformation of goethite into hematite. Structuration and complexation havee less function in microagregation. The humic horizon was formed by melanization kepty by stable humus-clay bonds. The addition, transformation and translocation of materials in the soil profile by the action of the fauna provokes the darkening of the microaggregates and the thickening of the humic horizon. The decomposition of charcoal also contributes to the melanization of the humic horizon. The humic oxisol were considered palaeosoils and were a fundamental link for the understanding of the landscap dynamics. The estabilishment of the landscape evolution model was possible only by integration geological, geomorphological and pedological information. 


\section{INTRODUÇÃO}

As regiões cratônicas dos trópicos são caracterizadas pela ausência de eventos de sedimentação de grande intensidade. Os processos que moldaram estas paisagens estão fundamentados nas taxas de intemperismolerosão, estabelecendo uma estreita ligação entre o regolito $\mathrm{e}$ a rocha subjacente. A compreensão da dinâmica destas paisagens passa por uma abordagem hoolística, envolvendo a ação integrada de processos geológicos, geomorfológicos e pedogenéticos.

A maior parte dos estudos sobre morfogênese e pedogênese é oriunda de regiões temperadas ou frias, onde as condições climáticas do passado recente e atuais são antagônicas às do ambiente tropical e influenciam decisivamente no estabelecimento da vegetação e na atividade biológica. Também a geologia superficial é na maior parte das vezes, bem distinta. Assim, pesquisas relacionadas com morfogênese e pedogênese nos trópicos devem enfatizar as condições tropicais, para ampliar os conhecimentos sobre a as paisagens e os solos desta crucial região do globo terrestre.

A evolução da paisagem nos trópicos e mais particularmente no Brasil Sudeste é um tema muito polêmico, encontrando-se na literatura modelos muito divergentes. Alguns dos principais modelos de evolução geomórfica foram elaborados nas décadas de 60 e 70, com destaque para os que contemplam a alternância de climas semi-áridos e úmidos ocorrida no Quaternário, em regiões ocupadas por antigas superfícies de aplainamento do Terciário, provocando o recuo de encostas e a formação de pedimentos nos períodos secos e dissecação e intemperismo nos períodos úmidos. Modelos de dinâmica de paisagens contemplando a ação da tectônica ressurgente também começam a ser elaborados para regiões cratônicas da faixa intertropical. A energia gerada pela reativação de falhas no Terciário e mesmo no Quaternário ativaria os movimentos de 
massa, provocando o reafeiçoamento de antigas superfícies de aplainamento. A presença de vestígios destas antigas superficies em diferentes altitudes (com topografia diferenciada), em regiões cratônicas, pode contribuir para a elucidação dos processos relacionados com a formação do relevo atual e com a distribuição dos solos na paisagem.

O segmento central do Sul de Minas Gerais pertence a um cráton muito antigo e apresenta feições geomorfológicas e distribuição espacial de solos intimamente relacionadas, proporcionando informações para estudos dos processos que atuaram na evolução das paisagens e na gênese dos solos. A necessidade de aprofundamento nos estudos sobre formação destas paisagens e de seus solos é preemente, pois existem muitas lacunas no conhecimento e as tentativas de preenchê-las não raramente são divergentes. Questões como a gênese dos latossolos e, em especial, a ocorrência de latossolos húmicos em distintos compartimentos geomorfológicos, onde as altitudes são diferentes e a topografia muda de plana a suave ondulada para fortemente ondulada devem ser investigadas, devido a estreitas relações entre estes solos e superfícies do Terciário.

Em um dos compartimentos geomorfológicos desta região, o predomínio de latossolos em todas as posições da encosta diverge dos sistemas onde ocorre a transição lateral do horizonte $\mathrm{B}$ latossólico para $\mathrm{B}$ textural ( $\mathrm{Bw}$ para $\mathrm{Bt}$ ) encosta abaixo, situação frequente no Brasil Sudeste.

A complexa distribuição dos solos nos compartimentos geomorfológicos mais movimentados é difícil de ser explicada, especialmente pelos modelos de evolução de paisagens ativados apenas por mudanças climáticas. Talvez esta complexidade pedológica pudesse ser melhor compreendida ao levar-se em consideração as evidências de uma tectônica ressurgente na região, com o posterior reafeiçoamento do relevo.

Esta situação é corrente e marcante na paisagem sulmineira, notadamente na região de Alfenas, mas poucos são os trabalhos encontrados na literatura relacionados com a evolução destas paisagens e a pedogênese.

Estudos que correlacionam solos e suas posições na paisagem, em conjunto com atributos do relevo e do material de origem, são fundamentais para a compreensão da gênese e distribuição dos solos. Desta forma, integrando-se informações de caráter 
geomorfológico, geológico e pedológico, objetiva-se, neste trabalho, interpretar a pedogênese em conjunto com a evolução da paisagem de uma área representativa de grande parte do Sul de Minas Gerais, pertencente aos municípios de Alfenas e Machado, nas proximidades do rio Machado, situada na transição entre uma superficie dissecada de topografia montanhosa e uma superficie rebaixada de patamares colinosos, cuja litologia é composta principalmente por gnaisses, migmatitos e charnoquitos. Ênfase especial será dada ao estudo dos latossolos húmicos, à influência da tectônica na formação da paisagem e na distribuição dos solos, à distribuição dos solos com horizonte $\mathrm{Bw}$ ao longo das vertentes, à gênese das linhas de pedras e à origem do horizonte microgranular e do B textural. 


\section{2- REVISÃO DE LITERATURA}

\section{1 - A necessidade de abordagem multidisciplinar em estudos de relações entre solos e paisagens.}

Nas últimas décadas, diversos pesquisadores têm se dedicado a estudos integrados de diferentes áreas das ciências da Terra, como a geologia superficial, a geomorfologia e a pedologia, para compreender a dinâmica e a distribuição dos solos na paisagem. Os principais interessados nesta integração são os geomorfólogos e os pedólogos, pois os primeiros complementam o estudo da forma da paisagem com aspectos inerentes à pedogênese e os últimos utilizam a compreensão da evolução da paisagem e dos processos que nela atuaram para resolver questões de pedogênese.

A problemática integrada dos aspectos fundamentais dos ambientes e das paisagens implica na abordagem e discussão da estrutura geológica, da evolução climática regional (atual e pretérita), bem como da análise dos principais eventos que conduziram à organização morfológica do relevo. São igualmente importantes os aspectos pedológicos e biogeográficos. Em síntese, a compreensão da estrutura e origem das paisagens necessita de abordagem interdisciplinar objetiva, considerando seu desenvolvimento no espaço e no tempo (Bigarella et al., 1994).

Diversos autores como Daniels e Hammer (1992), Gerrard (1992) e Gerrard (1993), se referem a esta integração como " Soil Geomorphology ", que significa relações entre pedologia, geomorfologia, geologia superficial e hidrologia. Os primeiros textos publicados sobre este assunto (Ruhe, 1975; Birkeland, 1974 e 1984) procuram estabelecer relações entre solos, seus materiais de origem e as superficies geomórficas 
que ocupam. Esta linha foi seguida no Brasil por Lepsch et al. (1975, 1977a e 1977b ), Vidal Torrado et al. (1989 e 1994), Curi et al. (1990) e Cooper (1996).

Para Hall (1983), a geomorfologia influencia grandemente os processos que direcionam a distribuição dos solos na paisagem e, por consequência, os processos pedológicos devem ser considerados como parte integrante da evolução da paisagem. A geologia superficial e a geomorfologia atuam grandemente sobre a hidrologia local, que por sua vez influencia a pedogênese e a distribuição dos solos (Daniels e Hammer, 1992). Daniels et al. (1971), expõe que trabalhos geomorfológicos são de máxima utilidade para os pedólogos quando são utilizados para reconstruir a história do local de trabalho, quando novas questões sobre morfologia e gênese dos solos surgirão.

Com a evolução dos estudos e desenvolvimento de tecnologias mais precisas para datações, elevou-se sobremaneira o número de informações detalhadas sobre mudanças climáticas no passado, flutuações no nível do mar, variações nos movimentos dos continentes e neotectônica, que indicam que estas condições mudaram muito durante o Quaternário (1,5 milhões de anos atrás) e muito mais, se considerarmos os 65 milhões de anos do Terciário (Gerrard, 1993).

Para este mesmo autor a evolução da paisagem é episódica, ou seja, provém da alternância de períodos relativamente longos de estabilidade geomorfológica com períodos curtos de instabilidade. Nos períodos de instabilidade ocorre, com maior intensidade, o reafeiçoamento do relevo, ativado principalmente pelo clima ( Bigarella et al., 1965a e 1965b; Bigarella \& Mouzinho, 1965; Ab"Saber, 1966; Penteado, 1968; Lepsch, 1975, 1977a, 1977b; Carmo et al., 1984; Lichte, 1990 e 1991; Vidal-Torrado \& Lepsch, 1993; Vidal Torrado, 1989 e 1994; Cooper,1996) ou notadamente pela tectônica (Almeida, 1980 e 1981; Hasui \& Almeida, 1978; Wernick et al., 1981; Hasui, 1985, 1990 e 1990a ; Saadi, 1990a, 1990b e 1991; Mioto,1984 e 1990).

Muitos dos autores citados no parágrafo anterior contemplam estas duas formas de energização do relevo, mas dão ênfase a uma delas. As feições da paisagem enfocadas neste trabalho sugerem a ação de ambos os fenômenos . O predomínio de um deles é dado pelas condições locais. 
Pedólogos poderão prever com boa margem de acerto a distribuição dos solos em paisagens não a eles familiares se abordarem o problema observando a geologia superficial e a geomorfologia e não estudando perfis isoladamente. As relações entre a hidrologia e a topografia de uma vertente sobre a gênese de seus solos só pode ser estabelecida reconhecendo a influência da geologia superficial e geomorfologia sobre os solos (Daniels \& Hammer, 1992).

Para prever o comportamento do solo o pedólogo deve interpretar a possível história da evolução da paisagem na qual o mesmo está inserido, estando em condições de interpretar e decifrar muitas coisas que podem ser desde aquelas eminentemente óbvias até um determinado comportamento estranho e anômalo (Daniels et al., 1971). Para Guerra \& Cunha (1995), estimular a cooperação interdisciplinar é fundamental para aprimorar e fazer avançar o conhecimento na interpretação dos processos e formas de relevo.

Pesquisadores como Daniels (1988), Bick \& Tandarich (1989) e Jacob \& Nordt (1991), em cartas ao editor do periódico Soil Science Society of America Journal, destacam a importância de trabalhos de campo que integrem a pedologia com outras áreas do meio fisico, para o entendimento das relações entre solos e paisagens.

Estudos sobre a dinâmica de paisagens deve englobar todos os segmentos que as compõe e não apenas um deles isoladamente.

Geologia estrutural, geomorfologia, pedologia e fitogeografia, cada uma delas estuda fenômenos cujas durações são desiguais, se constituindo, assim, em quadro para o desenvolvimento dos fenômenos de menor duração. Deste modo, para maior eficácia, os estudos devem ser conduzidos na ordem desta taxonomia temporal. O geomorfólogo só pode trabalhar em boas condições quando o quadro estrutural é conhecido. O pedólogo não pode dar sua medida se o quadro geomorfológico não é conhecido. O fitogeógrafo, por seu turno, deve dispor de dados pedológicos antes de começar sua pesquisas. Mas, as relações são dialéticas. Inversamente, a pesquisa numa disciplina de ordem taxonômica inferior fornece dados precisos que podem renovar e alterar certos resultados da disciplina de ordem superior (Tricart, 1968). 


\section{2 - Modelos de Evolução de Relevo}

Durante o decorrer do tempo geológico, a paisagem da Terra mudou radicalmente muitas vezes, influenciada por mudanças climáticas, tectonismo e vulcanismo; sendo normalmente controlada pela estrutura geológica. Porém, muito pouco da superficie da terra é mais antiga que o Terciário (cerca de 65 milhões de anos atrás) e a maior parte não é mais antiga que o Pleistoceno, ou seja, tem menos que 1,5 milhões de anos (Daniels \& Hammer, 1992). Mas, provavelmente, as áreas intertropicais apresentam maiores extensões de superficies terciárias, pois não estiveram sujeitas a ação de geleiras durante este período.

Várias hipóteses têm sido lançadas para explicar a evolução da forma da paisagem até atingir as extensas superficies de aplainamento atuais, que são consideradas pela maioria dos autores como estágio mais avançado da evolução do relevo. Os trabalhos clássicos tomam como base a ação dominante da erosão para explicar a evolução da forma das vertentes. Os principais são os trabalhos de Davis, Penck, King, (Young, 1972), Hack citado por Daniels e Hammer (1992), e de Ruhe (Ruhe et al., 1967); fundamentados na observação dos processos erosivos atuais (" O presente é a chave do passado").

Os modelos mais antigos, de Davis e Penck, foram elaborados utilizando-se metodologia semelhante, ou seja, ambos fizeram viagens para observação de várias paisagens da Terra para depois explicar a origem da forma das vertentes através de métodos dedutivos.

Pelo modelo de Davis (ciclo geográfico), a paisagem se rebaixaria conjuntamente partindo de um estágio inicial onde ocorre a elevação do nível de base com consequente incisão da paisagem pelos cursos d'água, formando taludes íngremes. As encostas recuariam através da diminuição gradativa de sua declividade, independente de sua forma inicial, originando um perfil convexo no topo e côncavo na base. A medida que o ciclo evolui, a topografia é amenizada e a área torna-se uma sucessão de colinas 
rebaixadas separadas por um vale aluvial de largura considerável, constituindo uma peneplanicie, Christofoletti (1980). Para Davis a paisagem evolui ciclicamente e as vertentes são aplainadas de cima para baixo (Figura 1a), de forma que não existiriam paisagens ou superficies remanescentes de outros ciclos (Daniels e Hammer, 1992), e seria necessária grande estabilidade tectônica.

O modelo de Penck (King, 1963; Young, 1972; Christofoletti, 1980), contempla um estágio inicial com encostas íngremes, que vão sendo erodidas em suas partes mais altas e declivosas e o material vai sendo depositado em sua base, originando uma superficie de aplainamento formada de baixo para cima (Figura 1b). Para Daniels e Hammer (1992), estas idéias de Penck evidenciam que superficies reliquiais podem permanecer na paisagem antes de serem removidas de baixo para cima.

Lester C. King viajou por vários países nas décadas de 50 e 60 , o que o possibilitou formar uma visão eclética dos outros modelos de evolução da forma da paisagem. Nos anos 60 este pesquisador elaborou um trabalho (King, 1963), no qual descreve a evolução do relevo por recuo paralelo das vertentes, originando pedimentos que com o passar do tempo se extendem por áreas cada vez mais amplas, dando à paisagem um aspecto multicôncavo, pois as concavidades dos pedimentos provenientes de várias direções acabam por se unir, originando os pediplanos ou pediplanícies (Christofoletti, 1980). De acordo com este modelo, todos os segmentos da vertentes sofrem erosão, mas os segmentos de maior declive (escarpa) mantêm o ângulo; o comprimento dos demais segmentos mantêm-se uniformes, com excessão da parte côncava do perfil, que aumenta de tamanho gradativamente, dando lugar a um recuo paralelo de vertentes (Figura 1c e 1d) ( Young, 1972; Young e Young, 1974). Quando esteve no Brasil, King interpretou a evolução da paisagem utilizando os conceitos de Davis e Penck e identificou cinco superfícies de aplainamento no Planalto Atlântico do Sudeste, citadas aqui em ordem cronológica decrescente: Gondwana, Pós-Gondwana, Sul Americana, Paraguaçu e Velhas (King, 1956). A descrição da peneplanação que dá origem a "Superficie Sul Americana" tem base davisiana e a pediplanação é explicada a partir dos conceitos de Penck. 
O modelo de Ruhe (Ruhe et al., 1967), também considera o recuo de vertentes, porém de forma não paralela, divergindo das idéias de Penck e King. Por este modelo, a parte superior da vertentes perde mais material do que a área mais próxima ao canal de drenagem, que vai sendo depositado nas adjacências deste, elevando gradativamente a concavidade do perfil (Figura le). Por outro lado, Ruhe corrobora as idéias de Penck e King, pois também prevê a possível ocorrência de remanescentes de superfícies antigas. Vários autores (Ruhe et al., 1967; Daniels e Gamble, 1967; Daniels et al., 1970; Gile e Hawley, 1966; Gile, 1975a, 1975b), testaram este modelo em diferentes condições de clima e geologia superficial e encontraram bons resultados na interpretação das relações solo-paisagem.

Em 1960, John Hack, citado por Bigarella et al. (1965) e por Daniels e Hammer (1992), desenvolveu o modelo do equilibrio dinâmico, que descreve a evolução do relevo pelo rebaixamento uniforme de todos os elementos topográficos da paisagem, que mantêm sua forma original (Figura 1f). A taxa de rebaixamento variaria de acordo com a resistência do material subjacente. As formas e processos estariam num equilíbrio estável e seriam independentes do tempo em paisagens onde as forças exógenas e endógenas se equivalessem em intensidade. Porém, este modelo só pode ser validado na ausência total de tectonismo.

Resende (1982) usa a relação pedogênese/erosão para explicar a dinâmica da paisagem e o estágio de desenvolvimento dos solos. Quanto maior esta relação, mais estabilizada é a superficie e mais desenvolvido é o solo. Um modelo de evolução da paisagem baseado na intensidade dos processos pedogenéticos e nas perdas por erosão que ocorrem em cada uma das nove unidades hipotéticas de vertente foi proposto por Darlymple et al. (1968). Apesar deste modelo apresentar um padrão ideal para ser aplicado na compartimentação de uma vertente (Vidal Torrado, 1994), o mesmo tem recebido críticas por não levar em consideração a idade relativa das diferentes partes da paisagem; o que é considerado por Daniels \& Hammer (1992) de fundamental importância para o entendimento da distribuição e comportamento dos solos na mesma. 
a)

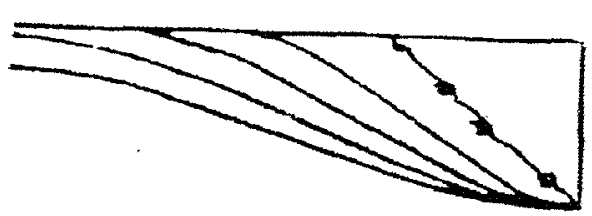

c)

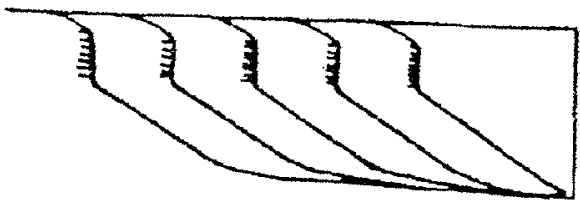

e)

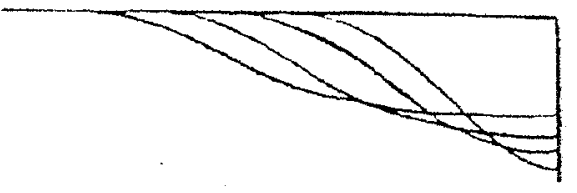

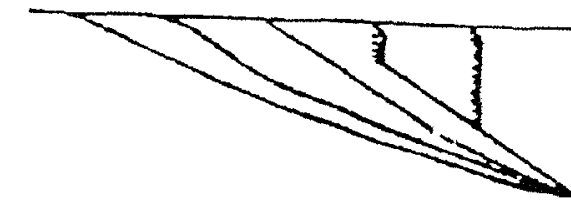

b)
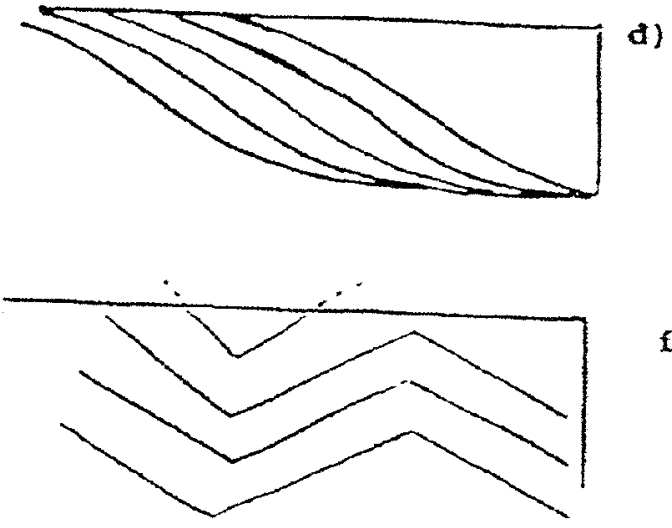

f:

Figura 1- Principais modelos de evolução do relevo: a) Davis: decréscimo progressivo do relevo. b) Penck: reposição sucessiva do processo erosivo. c e d) King: recuo paralelo de vertentes, sendo em c) com escarpa e em d) sem escarpa. e) Ruhe: recuo de vertentes em fase gradacional com maior retirada de material nas partes mais altas. f) Hack: equilibrio dinâmico da paisagem sem alteração da forma do relevo.

Fonte: Vidal Torrado (1994).

Após intensos trabalhos realizados no sudeste brasileiro e discussão dos modelos clássicos de evolução da paisagem, Bigarella et al. (1965a), concluem que a paisagem atual foi modelada pelas alternâncias climáticas ocorridas no Quartenário. Nos períodos de semi-aridez que correspondem aos glaciais quaternários, as vertentes recuaram por forte erosão formando pedimentos e seus depósitos correlativos. Nos períodos úmidos, correspondentes aos interglaciais, as rochas foram intemperizadas e os vales entalhados. Este modelo foi adotado por Vidal Torrado \& Lepsch (1993) no embasamento cristalino de Mococa(SP), área que apresenta características semelhantes em relação a área deste trabalho; por Penteado (1968) e Vidal Torrado (1994) na depressão periférica paulista; 
por Carmo et al. (1984) na região do Alto Paraiba(MG); por Curi (1983) Curi \& Franzmeier (1984) no Planalto Central(GO) e no Quadrilátero Ferrífero(MG); por Resende (1976) no triângulo mineiro; dentre outros.

Porém, de acordo com o modelo de Davis, a dissecação da paisagem ocorre em clima úmido, sem necessidade de fase seca. Outros pesquisadores também questionam a necessidade de fases secas no processo de dissecação da paisagem. Para eles a dissecação ocorre nas fases com excesso de umidade, quando movimentos de massa e erosão hídrica passam a atuar com maior intensidade e a cobertura vegetal mostra pouca eficiência na minimização destes processos.

Holmes (1955) citado por Penteado (1974) também explica evolução das vertentes por alternância climática. Quando o clima é úmido o rio escava verticalmente e as vertentes possuem perfis convexos. Quando o rio encontra uma camada mais resistente, para de cavar, começa a alargar, o vale e a vertente vai recuando, com sua base se tornando cada vez mais côncava. Com o estabelecimento de uma cobertura vegetal mais densa e a suavização dos declives descrita anteriormente, a relação pedogênese/erosão eleva-se, os solos se desenvolvem e a paisagem passa por um período de relativa estabilidade. Na transição de clima úmido para semi-árido, a vegetação declina e as chuvas intensas diminuem marcantemente a relação pedogênese/erosão. Desta forma as vertentes recuam de forma acelerada, suavizando os declives e provocando o surgimento de pedimentos espessos, onde pode ocorrer coalescência, originando extensos pediplanos. $O$ ciclo se reinicia com a retomada do clima úmido (figura 2).

Uma abordagem sobre a influência da tectônica na evolução do relevo é dada por Hasui (1990): "a morfogênese do território brasileiro decorreu dos processos tectônicos que incidiram após o Triássico e culminaram com a abertura do Atlântico e deriva dos continentes, envolvendo soerguimentos, horstes e grabens gerados por falhas, domos levantados por intrusões, formação de derrames vulcânicos, erosão e sedimentação".

Bigarella et al. (1994), incluem novos conceitos em seu trabalho e cita que os tipos de paisagens são derivados da interação entre tectônica, estrutura geológica, fatores climáticos e agentes geológicos. O relevo resulta do equilíbrio entre a meteorização da 
rocha e sua resistência aos processos morfoclimáticos. Na paisagem destacam-se áreas onde a estrutura geológica desempenha papel preponderante e outras, onde as ações morfoclimáticas predominam. No primeiro caso, a morfologia é essencialmente estrutural. Não resta a menor dúvida que o fator tectônico determina a energia do relevo, ligado principalmente aos movimentos epirogenéticos ou aos grandes falhamentos, arqueamentos e dobramentos. O efeito paisagístico dos dois conjuntos de processos várias em função do clima e da natureza das rochas.

Nas últimas décadas, vêm ganhando ênfase a ação da erosão geoquímica (definida por Tardy em 1990 como o processo que precede a erosão mecânica e que se refere a perda de matéria em profundidade), na evolução das formas de relevo. Nos caminhos preferenciais da água abaixo do solum, as fendas e fraturas das rochas, as reações químicas de oxi-redução ocorrem em maior intensidade, acarretando em desequilibrio químico nos minerais e consequente depleção de elementos.

Trabalhos desenvolvidos em áreas de arenitos por Pellerin e Queiroz Neto (1992) e por Filizola e Boulet (1993) sugerem uma grande contribuição de erosão geoquímica na evolução do relevo atual. Em áreas do embasamento cristalino,como a deste estudo, este tipo de erosão pode assumir grande importância no modelo de relevo, pois as rochas ocorrentes são formadas por minerais com resistência contrastante ao intemperismo.

Como foi visto anteriormente, existem vários modelos de evolução da forma de paisagem, alguns com enfoques bem contrastantes. Daniels \& Hammer (1992) suspeitam que as paisagens dentro de um determinado ambiente foram desenvolvidas por vários processos e que é um engano abraçar um único modelo. Para os mesmos devemos sempre testar nossas idéias e estarmos abertos por mudá-las quando novos dados e evidências surgirem. 

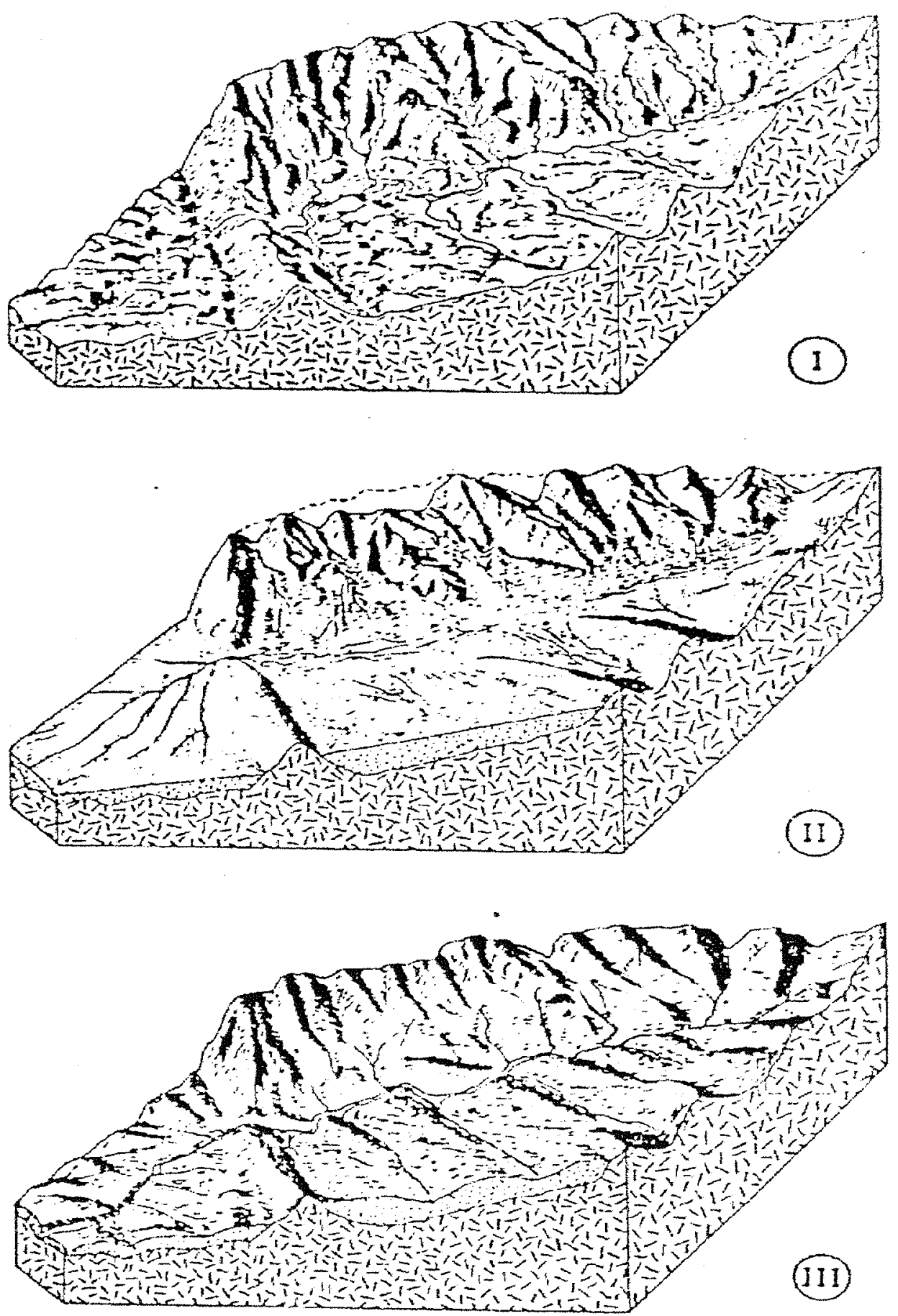

Figura 2 - Representação de uma área localizada no escudo cristalino do sudeste do Brasil antes e depois de mudanças climáticas envolvendo clima úmido (fases I e III ) e clima semi árido (Fase II). Adaptado de Lepsch et al. (1986). 


\section{3 - Considerações a respeito da Geologia do Sul de Minas Gerais}

O Sul de Minas Gerais é uma região com história geológica altamente complexa, de evolução policíclica e polifásica, que remonta desde o Arqueano até o Pré-Cambiano Superior/Eopaleozóico, caracterizada por eventos metamórficos, magmáticos, anatéticos/migmatíticos e deformacionais superpostos. Estes terrenos compreendem várias unidades lito-estruturais quer de infra-estrutura quer supracrustais (Artur, 1988).

Almeida (1980) explica que no Sul de Minas expõe-se o complexo gnaissicogranítico( datado de 2,6 bilhões de anos atrás) que serve de embasamento ao grupo Bambuí. É ao sul do imponente sistema de falhas da região de Nepomuceno-Carandaí (Schobbenhaus Filho, 1978), que aparecem extensivamente as rochas de alto grau metamórfico, distribuídas ao longo de uma faixa paralela à costa e outra que se dirige a NW, para a região de Alfenas-Varginha-Guaxupé. Esta última inclui gnaisses charnoquíticos e granulíticos polimetamórficos (Ebert, 1968: Oliveira, 1973; Oliveira \& Alves, 1974; Choudhuri et al., 1978). As datações disponíveis indicam idades transamazônicas (cerca de 2 bilhões de anos atrás) e brasilianas (cerca de 600 milhões de anos atrás) (Wernick et al., 1976; Oliveira, 1973).

As principais unidades lito-estratigráficas de infra-estrutura da área estudada (região de Alfenas, MG) são o Complexo Amparo e o Complexo Guaxupé, enquanto que a unidade litoestrutural supracrustal mais ocorrente é o Complexo Andrelândia (Artur, 1988). Radambrasil (1983) se refere ao Complexo Guaxupé como Complexo Varginha, Schobbenhaus et al. (1984) como Complexo Varginha-Guaxupé , Minas Gerais (1983) como sequência Varginha-Guaxupé e Fiori (1979) como Complexo Silvianópolis. Estas unidades limitam-se ao sul com o Complexo Poços de Caldas. A intrusão alcalina cretácico-terciária ocorrida neste complexo causou reflexos nas unidades lito-estratigráficas da região.

As rochas do Complexo Guaxupé seriam originalmente de idade arqueana, adquirindo estrutura foliada através de intenso cisalhamento durante o evento tectometamórfico denominado ciclo Transamazônico (cerca de 2 bilhões de anos atrás) 
(Artur, 1988; Radambrasil, 1983), pouco afetadas pela compressão do ciclo Brasiliano (Radambrasil, 1983) e que não sofreram rejuvenescimento por eventos pós-arqueanos (Artur, 1988). As principais rochas deste complexo são gnaisses granulíticos homogêneos e bandados, intercalados com granulitos básicos (charnoquitos), gnaissificados ou maciços, constituidos por quartzo, horblenda, hiperstênio, piroxênio, biotita e feldspato escuro (Minas Gerais, 1976; Schobbenhaus et al., 1984; Radambrasil, 1983; Artur, 1988). Os gnaisses foram datados em 950 milhões de anos por Hama (1979) e em 2,6 bilhões de anos por Almeida (1980). Os charnoquitos foram datados em 640 milhões de anos por Hama (1979).

O Complexo Amparo corresponde a uma unidade gnaissico-migmatitica resultante do retrabalhamento das associações litológicas do Complexo Guaxupé e Complexo Barbacena por fenômenos anatéticos durante o ciclo Transamazônico, acrescida de granitos variados ligados ao mesmo evento tectometamórfico, datados do proterozóico inferior, modificados ou não em eventos posteriores (Artur, 1988). Para Radambrasil (1983), este complexo faz parte da faixa de dobramento CanastraCarrancas-Amparo ( o que corresponde em parte ao "Araxaídes" de Ebert, 1956), possivelmente do Proterozóico inferior, retrabalhada com maior ou menor intensidade no ciclo Brasiliano de metamorfismo (cerca de 600 milhões de anos atrás). Suas rochas predominantes são migmatitos, gnaisses migmatizados, biotitas gnaisses e hornblendabiotita gnaisses (Minas Gerais, 1976 e 1983; Schobbenhaus et al., 1984; Radambrasil, 1983; Artur, 1988), originadas de sedimentos clastopsamíticos a pelíticos e clastoquímicos quase sempre impuros, associados a corpos básicos e ultrabásicos.

Hasui et al. (1990) expõe que zonas de cizalhamento de baixo ângulo tendem a se instalar em regiões de contato entre litologias ou graus metamórficos diferentes como, por exemplo, na zona de contato entre os complexos Guaxupé e Amparo.

O Complexo Andrelândia está representado basicamente por rochas metamórficas e metassedimentares variadas, com quantidades variadas de rochas metaígneas e com idades variando em torno de 600 milhões de anos, sendo grandemente influenciadas pelo ciclo Brasiliano (Radambrasil, 1983). Trata-se de uma unidade essencialmente supracrustal, do proterozóico médio (Artur, 1988). São constituídas por 
gnaisses, migmatitos, micaxistos aluminosos com frequentes lentes de quartzitos, anfibolitos; ortognaisses graníticos e granitóides (Minas Gerais, 1976 e 1983; Schobbenhaus et al., 1984; Radambrasil, 1983; Artur, 1988). As rochas deste complexo estão a cerca de $30 \mathrm{~km}$ da região enfocada neste estudo.

O Complexo de Poços de Caldas, com $800 \mathrm{Km}^{2}$ de área, constitui-se em uma das maiores intrusões alcalinas do mundo. Encontra-se encaixado entre granitos e gnaisses de idades pré-cambrianas , Ellert(1959). Para Bushee (1974) este vulcanismo é alcalino de natureza ultramáfico félsica, ocorrido entre 89 e 52 milhões de anos atrás. Amaral (1966) e Bushee (1974) dataram estas rochas em 80,9 a 52,9 milhões de anos atrás.

Este complexo é na verdade uma imensa caldeira (cratera de abatimento), formada a cerca de 60 milhões de anos atrás pelo colapso do edifício vulcânico, que perde apoio interno devido ao vazio resultante da saída do magma ou devido ao refluxo do magma que se assenta graças ao escape dos gases. Como consequência direta deste fenômeno, formam-se ao redor do edifício vulcânico e de sua câmara magmática, zonas de fraturamento e abatimento (Leinz e Amaral, 1985) que podem resultar num basculamento de blocos regional.

De acordo com Ellert (1959), a evolução geológica do Complexo de Poços de Caldas se processou através das seguintes fases: levantamentos, provavelmente escalonados por falhas, de blocos do embasamento após sedimentação do Arenito Botucatu de idade triássica; atividades vulcânicas com formação de tufos, brechas e lavas; subsidência da parte central; ascensão do magma nefelínico por fendas radiais e circulares; e formação do dique anelar.

\section{4 - Evolução do relevo no Sul de Minas Gerais}

O Sul de Minas Gerais situa-se no Planalto Leste, também chamado Planalto Atlântico do Sudeste, o qual esta integrado na acidentada porção do território brasileiro 
conhecida por Brasil Sudeste (Ab'Saber et al., 1958), definida por De Martonne (1953) como Brasil Tropical Atlântico. A grosso modo é constituído por um planalto variavelmente movimentado que regionalmente está compreendido no Peneplano do Alto Rio Grande ou Planalto do Sul de Minas, limitando-se a noroeste com o Planalto Central e a nordeste com a bacia do Alto São Francisco, a sudoeste com a bacia do Paraná e sudeste com com a Serra da Mantiqueira (Camargo et al., 1962).

Suas principais unidades geomorfológicas são o Planalto Dissecado do Sul de Minas e a Depressão do Rio Grande, que durante seu desenvolvimento isolou trechos do Planalto Dissecado (Minas Gerais, 1983). Estas unidades recebem denominações diferentes de outros autores e formam a região dos estudos.

Nesta região, os estudos de geomorfogênese que procuram ordenar as etapas da evolução do relevo, a natureza das formações superficiais, as constatações morfoclimáticas e suas consequências na organização do relevo são grandemente dificultados pela inexistência de depósitos antigos e a intensa atividade orogênica ocorrida a partir do Mesozóico dificultam a montagem do quadro geomorfológico antes do Terciário (Radambrasil, 1983).

De acordo com Radambrasil (1983), a região de Alfenas está compreendida no domínio do Escudo exposto, área com características morfoestruturais de estabilidade, apresentando exposição de rochas cristalinas integrantes de uma plataforma ou cráton, que resistiram a ações dos ciclos posteriores ao Arqueano. Encontra-se envolvida por faixas móveis consolidadas, sem ter sofrido ulteriores ações tectônicas de grande porte. Este domínio abrange áreas cujos aspectos geomorfológicos foram elaborados em diferentes litologias pré-cambrianas como os complexos Varginha e Amparo. Estas litologias sofreram deformações e deslocamentos, resultando em blocos de relevos alçados, posteriormente atingidos por estágios sucessivos de erosão, decorrentes de variações paleoclimáticas as quais, incidindo sobre as rochas cristalinas e metamórficas, produziram pacotes de alteração evoluidos tanto em profundidade como em extensão areal, modelados por dissecação homogênea e diferencial.

A região do Planalto de Poços de Caldas -Varginha compreende basicamente as áreas de ocorrência das litologias dos complexos Varginha e Amparo, migmatizadas e 
granitizadas no Ciclo Brasiliano, predominando gnaisses, migmatitos, granulitos e charnoquitos. Estas litologias foram perturbadas por intrusões alcalinas cretácicoterciárias exemplificadas no maciço de Poços de Caldas. Esta intrusão produziu reflexos em áreas próximas, como cristas de orientação circular. Vestígios de falhamentos e fraturas orientadas na direção SW-NE e SE-NW também denunciam as perturbações tectônicas que afetaram estas antigas estruturas do escudo (Radambrasil, 1983). Para King (1956) este maçiço testemunhou a fase de aplainamento correlacionada a "Superficie Sul Americana".

Este domínio foi dividido em duas regiões geomorfológicas: o Planalto CentroSul de Minas e o Planalto de Poços de Caldas-Varginha. Neste último foram identificadas duas unidades geomorfológicas: o Planalto de Poços de Caldas e o Planalto de Varginha (Radambrasil, 1983). No limite entre estas unidades está inserida a área deste estudos.

No Planalto de Varginha as altimetrias variam de $800 \mathrm{~m}$ nas margens da represa de Furnas a $1200 \mathrm{~m}$, em algumas cristas destacadas e toda a rede de drenagem pertence a bacia do Paraná. As litologias dominantes são arqueano-proterozóicas dos Complexos Varginha e Amparo (Radambrasil, 1983). Porém, Artur (1988) identificou nesta região rochas do Complexo Andrelândia.

O modelado do relevo é, predominantemente, de dissecação homogênea, com densidades finas a grosseiras e aprofundamento oscilando entre 38 e 115 metros. Configuram interflúvios de topos planos e vertentes de forma convexa.

As características úmidas atuais associadas às formações superficiais espessas, de textura argilosa ou areno-argilosa, auxiliam a atuação de erosão areolar com tendência a sulcamentos e voçorocamentos localizados. Tais processos são acelerados pela ação antrópica. Silva et al. (1993), encontraram 162 voçorocas em uma área adjacente de 618 $\mathrm{Km}^{2}$ e com topografia semelhante à região destes estudos. Os locais mais elevados são representados por algumas linhas de cumeada e formas de topos aguçados, (Radambrasil, 1983).

O Planalto de Varginha corresponde a área descrita por Camargo et al. (1962), como extensos interflúvios bastantes rebaixados e ligeiramente ondulados, formando uma sucessão de colinas tabuliformes amplas, cujos desnivelamentos locais não ultrapassam 40 
a 50 metros. No seu conjunto, as formas de relevo são muito suavizadas, que contrastam grandemente com o modelado mais movimentado de pequenos maciços montanhosos ilhados e áreas circunjacentes mais elevadas, para os quais gradam ou com os quais se defrontam.

Sua evolução Cenozóica é pouco documentada do ponto de vista da tectônica recente. Porém, no Terciário (ou final do Cretáceo) a intrusão alcalina em forma de anel de Poços de Caldas produziu reflexos em áreas próximas. Também do ponto de vista morfoclimático não é muito ampla a documentação sobre depósitos correlativos de períodos de erosão, mas pode-se inferir que os climas que elaboraram as superficies ocupadas por estes domínios foram bastantes severos e extensivos, pois transgrediram áreas pertencentes ao Escudo Exposto, atingindo o domínio dos remanescentes de cadeias dobradas, que foram niveladas na parte correspondente ao Planalto de Andrelândia, de litologia supra crustal (Radambrasil, 1983).

Camargo et al. (1962), procuraram explicar a evolução geomorfológica deste planalto intensamente dissecado por uma sequência de vários ciclos de erosão que originaram as formações fisiográficas atuais. Estes autores identificaram na área dos estudos duas superficies de erosão: a Superficie Dissecada de Topografia Montanhosa e Morros Residuais e a Superficie Rebaixada de Patamares Colinosos.

A Superficie Dissecada de Topografia Montanhosa se correlaciona com a Superficie Sul Americana do Terciário Inferior (King, 1956); com a Superficie Paleogênica de De Martonne (1953); com a Superficie Pós-Cretácea de Almeida (1959); com a Superficie DM2 (Dissecada média com aprofundamento de canais de 60 a 71 metros) do Planalto de Varginha, descrito por Radambrasil (1983) e com o Planalto Dissecado do Sul de Minas (Minas Gerais, 1983). Andrade (1979) trabalhando em área adjacente, correlacionou esta superfície com a Superficie Pós-Gondwana de King (1956).

De Martonne (1953) correlacionou os topos situados entre 1.000 e $1.100 \mathrm{~m}$ no sudeste do Brasil a uma paleo-superficie de aplainamento datada do Terciário Inferior, sendo que os situados logo abaixo seriam originados por um ciclo erosivo do Terciário Superior, relacionado à Superfície Velhas. 
A superficie Dissecada compreende extensas seções de topografia ondulada vigorosa que se dispõe escalonadas em cotas entre 900 e 1100 metros de altitude; corroborando as observações de Hasui (1990), para o qual esta superfície foi aplainada no Terciário e em seguida alçada até as altitudes atuais, sendo posteriormente dissecada. Apresentam configuração superficial bastante movimentada, do tipo mar de morros e pequenas serras ligeiramente sobre elevadas conformando sequência de elevações de topos arredondados ou quebrados, vertentes convexas ou convexo-côncavas com declives acentuados e pequenos vales de fundo côncavo quase sem terraços marginais (Camargo et al., 1962). Para Andrade (1979), está é uma superficie dissecada, bastante afetada pela ação da erosão diferencial, com influências estruturais e litológicas. Curi et al. (1990), trabalhando em área adjacente encontraram nesta superficie substrato composto por gnaisses graníticos ou quartzitos; relevo forte ondulado a montanhoso, topo convexo, encostas côncavas; solos litólicos e podzólicos associados a afloramentos de rochas.

Após a elaboração da Superfície Sul Americana, no Mioceno, ocorreu uma grande transgressão marinha na costa brasileira e cobertura da superfície por processos de sedimentação. Seguiu-se o soerguimento do continente e a elaboração de superficie mais recente (Magalhães Júnior, 1990).

A Superficie Rebaixada Patamares Colinosos se correlaciona com a Superficie Velhas do Terciário Superior (King, 1956), com a Superficie Neogênica de De Martonne (1953); com a Superficie DM1 (Dissecada média com aprofundamento de canais de 38 a $51 \mathrm{~m}$ ) do Planalto de Varginha, descrito por Radambrasil (1983) e com a Depressão do Rio Grande (Minas Gerais 1983). Para Andrade (1979) esta superficie se correlaciona com a Superfície Sul Americana de King (1956).

Constitui esta superficie extensas plataformas interfluviais bastante rebaixadas e levemente dissecadas, onde os desenvolvimentos locais não ultrapassam $50 \mathrm{~m}$, com uma generalizada concordância de níveis de topos aplainados a uma altitude dominante um pouco acima de 800 metros. É uma superficie senil, relativamente estabilizada e caracterizada por formas suaves (Camargo et al., 1962). Porém, em uma área do leste de Minas Gerais cujos clima, litologia e topografia assemelham-se aos do Sul de Minas, 
Lichte (1990 e 1991) datou os sedimentos superficiais (solo) através de termoluminescência e pelo método do Carbono-14, em 20.000 anos.

Segundo Camargo et al. (1962), como a superficie rebaixada se encontra relativamente estabilizada, a erosão é reduzida e, em decorrência, a taxa de pedogênese é alta, proporcionando intensa meteorização que progride gradualmente em profundidade. A profundidade do regolito, a ausência de afloramentos de rochas, o avançado estágio de transformação dos solos e as formas suavizadas do modelado topográfico são, dentre outros, os fatores citados para comprovar estabilização desta superficie. Porém, para Resende (1979) citado por Andrade (1979), a mesma não se encontra tão estabilizada. O regolito é profundo, mas é formado por um horizonte $\mathrm{C}$ profundo acompanhado de horizonte superficiais $\mathrm{A}$ e $\mathrm{B}$ pouco espessos, o que indica uma baixa relação pedogênese/erosão, decorrente de um processo erosivo mais acentuado. Também na região enfocada neste estudo, não é rara sua associação com afloramentos de rocha.

Curi et al. (1990), encontraram para esta superficie em área adjacente um embasamento rochoso formado por gnaisse granítico, relevo suave ondulado a ondulado com encostas convexas; latossolos com espessura do solum variando de 2 a 5 metros.

Nas décadas de 60 e 70 muitos estudos geomorfológicos ou pedogeomorfológicos baseados em modelos centrados nas alternâncias climáticas ocorridas durante o Quartenário no Brasil Sudeste foram realizados. Destacam-se os trabalhos Bigarella e sua equipe em Curitiba(PR), Ab'Saber e Queiroz Neto na USP e de Penteado e Christofoletti em Rio Claro (SP). A partir da década de 80 até os dias atuais pouco foi acrescido a estes trabalhos, talvez em função das muitas dúvidas e incertezas que o modelo apresenta e da dificil datação absoluta dos eventos quaternários (Vidal Torrado, 1994).

Para Bigarella et al., (1965b) a evolução das vertentes é consequência da mudanças climáticas ocorridas no Pleistoceno. Durante época de clima úmido (que correspondia aos períodos interglaciais do hemisfério norte) a paisagem era dissecada. Ao mesmo tempo era formado um manto de intemperismo pela decomposição química das rochas em profundidade e a denudação ocorria principalmente por movimentos de massa. Quando o clima mudava para semi-árido (principalmente na época de transição), que 
corresponde aos períodos glaciais do hemisfério norte, a paisagem se desenvolvia por morfogênese mecânica, degradação lateral e retração pararela das vertentes, levando a processos de pedimentação (figura 2). A sequência repetitiva de climas secos e úmidos é o mecanismo de gatilho para cada um destes grupos de processos (Resende, 1976).

Porém, Ross (1991), afirma que a intensa pedogeneização do ambiente tropical úmido tende a eliminar os testemunhos da alternância morfogenética provocada pela ação de climas semi-áridos ou úmidos, reduzindo as chances de uma boa interpretação dos paleoambientes e da gênese da paisagem. Por outro lado, Penteado (1968) argumenta que, como não houve ação de geleiras durante o Quaternário, as formas levemente convexas e a cobertura vegetal natural, hoje quase inteiramente modificada (a região em enfoque apresenta menos de $6 \%$ da cobertura vegetal natural, de acordo com Campos \& Landgraf, 1990), estariam sob influência do clima atual quente e úmido, que pela pouca expressão que esta fase teve na escala de tempo geológico, ainda não foi capaz disfarçar e/ou destruir todas as paleoformas.

Vidal Torrado (1994), cita que diversos autores estudaram o sudeste brasileiro e interpretaram a paisagem como resultado desta alternância climática global durante 0 quaternário, sendo que para cada fase glacial correspondeu um clima semi-árido no ambiente tropical. Os efeitos desta alternância climática, pressupondo-se que algumas das formas decorrentes permanecessem na paisagem como cicatrizes, tornaram mais complexo o entendimento das relações solo-paisagem, em comparação com as regiões de médias a altas latitudes devastadas pela ação arrasadora das geleiras.

Embora reconheça estas dificuldades para a interpretação da evolução da paisagem, Vidal Torrado (1994) verificou grande correlação de depósitos superficiais e das formas de relevo encontrados, com aqueles encontrados em outros estudos conduzidos no Brasil Sudeste, todos convergentes para a hipótese de evolução do relevo em função de alternâncias paleoclimáticas quaternárias. $\mathrm{O}$ autor destaca a similaridade de coberturas de topos, depósitos de encosta, níveis antigos e atuais de terraços e linhas de pedras encontrados por ele sobre rochas do Grupo Tubarão (Carbonífero-Permiano), em relação aos mesmos atributos da paisagem encontrados por Penteado (1968) sobre 
rochas do Grupo Passa Dois (Permiano). As áreas estudadas por estes dois pesquisadores se encontram na Depressão Periférica Paulista.

Topos planos elevados, terraços, colúvios, linhas de pedras, paleossolos e couraças de lateritas têm sido utilizados como indicadores para estabelecer relações entre glaciações e interglaciações e a evolução do modelado na América Tropical. (Ab'Saber, 1966; Bigarella et al., 1965a e 1965b; Bigarella \& Mousinho, 1965 ; Penteado, 1968; De Boer, 1972; Dias-Ferreira et al., 1975; Demattê \& Hollowaychuck, 1977; Lepsch, 1977a; Tyler et al., 1978; Queiroz Neto e Journaux, 1978; Meis, 1978; Melo e Ponçano, 1983; Curi, 1983; Radambrasil, 1983; Carmo et al., 1984; Vidal Torrado \& Lepsch, 1993; Vidal Torrado, 1994)

Turcq et al. (1987), Lichte (1990 e 1991) e Absy et al. (1991), contribuiram para um maior embasamento da idéia de alternâncias climáticas atravéz de datações com $\mathrm{C}^{14}$, termoluminescência e palinologia; porém com ênfase para o holoceno e final de pleistoceno.

\section{5 - Crátons, faixas móveis e falhas geológicas}

Crátons são áreas continentais estáveis constituídas por rochas metamórficas de alto grau e tendo faixas móveis desenvolvendo-se em sua periferia. Quando ocorre a exposição de rochas metamórficas ( gnaisses e ígneas magmáticas ), o relevo esculpido é geralmente suave e resultado da erosão seletiva ao longo das linhas de fraqueza, relacionadas com fraturas, juntas, dobras ou rochas débeis que formam depressões ou então rochas duras que tendem a originar áreas elevadas (Guerra \& Cunha, 1995).

Subrahmanyam (1978) observou que na Índia Peninsular, o limite entre dois crátons é caracterizado por ser constituído de rochas granulíticas e charnoquíticas ("greenstone belts"). Baseando-se em anomalias de gravidade este autor interpreta como contato por falha, separando a crosta mais densa e elevada do cinturão granulítico da crosta mais leve, dos crátons (rochas arqueanas de baixo a médio grau de metamorfismo). 
Schaefer (1996) afirma que superficies datando do Terciário, Cretáceo ou mais antigas, após o deslocamento por movimentos tectônicos, formam as áreas cratônicas do Brasil em cotas elevadas,antigas e estáveis. Então, muito do material dos solos de hoje, foram sujeitados a repetidos ciclos de pedogênese, atividade biológica, erosão e deposição, sobre variado regime climático, por longo período de tempo. Desta forma, poucos solos são somente o produto de processos pedogenéticos e bióticos que operam nos dias de hoje.

Faixas móveis são regiões crustais longas e estreitas que sofreram intensa atividade tectônica com a formação de rochas e deformação em larga escala, que produziram sistemas montanhosos já destruídos pela erosão . No Sul de Minas Gerais ocorreram o Ciclo Transamazônico (2.200 a 1.800 milhões de anos atrás) e o Ciclo Brasiliano (700 a 450 milhões de anos atrás). O material geológico destas faixas, hoje exposto em suas raizes, pode até formar relevos montanhosos posteriores sem nenhuma conotação com a orogênese, como, por exemplo, a reativação de antigas linhas de falhas (Guerra \& Cunha, 1995). A região destes estudos está localizada entre as faixas móveis da Mantiqueira (Cinturão Transcorrente Cássia-Barbacena) e do Planalto Central (Cinturão transcorrente Carandaí-Ouro Fino ), Almeida (1980).

Saadi (1990) define o Sul de Minas Gerais como área de contato entre a extremidade meridional do Cráton do São Francisco e unidades estruturais dos cinturões dobrados. Este mesmo autor expõe que as denominações destes cinturões assim como as concepções relativas à borda sul do cráton foram debatidas por Almeida (1981) e Wernick et al. (1981).

Regionalmente esta faixa é definida por Almeida, (1980) como cinturão móvel de Alfenas. Este se caracteriza pelo caráter lábil manifestado pelo menos desde o início do Proterozóico.

Estreitamente relacionadas a estas faixas ocorrem as falhas geológicas, definidas por Guerra \& Cunha (1995) como uma fratura na crosta terrestre com deslocamento relativo, perceptível entre os estados contíguos e ao longo do plano de fratura. Pode ser observado em escala micro (microfalhas) ou em escala macro (falhas regionais). Os principais tipos são falha normal (formada por forças de tração); falha de empurrão ou 
inversa (forças compressivas) e falha horizontal ou trancorrente (forças cizalhantes). As feições lineares do fraturamento da crosta são facilmente identificadas na superficie por meio de fotografias aéreas e imagens de satélite, muitas vezes promovendo variações bruscas da litologia que se refletem no relevo. Assim, dependendo da amplitude e idade do falhamento, a configuração do terreno será afetada em maior ou menor de grau, não obstante ser esta influência quase sempre indireta e provocada por processos erosivos na área afetada ou por fenômenos de reativação tectônica ao longo de antigas linhas de fratura.

Falhas são fraturas nas quais ocorre um deslocamento perceptível das partes, o que se dá ao longo de um plano de fratura. Podem-se originar por esforços de tração ou de compreensão (falhas tectônicas); ou ainda pelo desabamento provocado pela dissolução de rochas da sub superficie, por colápso nas proximidades de crateras vulcânicas ou pela acomodação de sedimentos plásticos (falhas atectônicas). Os planos de falhas são as superficies segundo as quais se dão os deslocamentos. Muitas vezes o atrito causado pelo movimento produz uma superficie lisa e polida (espelho de falha), que pode também mostrar estrias ou caneluras. Estas são provocadas pela fricção de grãos mais salientes (Leinz \& Amaral, 1985).

O Brasil se insere no cenário de uma placa litosférica em movimento para WNW, com movimentos epirogenéticos positivos e menos expressivamente, negativos. A atividade estrutural da movimentação da placa, se dá eminentemente por falhas cuja atividade é de caráter ressurgente, condicionada pelas zonas de cizalhamento e suturas ligadas à estruturação de primeira ordem, da antiga crosta no território. As falhas são predominantemente transcorrentes ou de empurrão, mas podem aparecer outros tipos de falhas, em função do ângulo entre as feições reativadas e as tensões ( Hasui et al. 1990a).

Escarpas de falha são geradas exclusivamente pela movimentação vertical e recente de blocos falhados, onde a declividade, formada sobre o bloco ascendente, coincide com o plano de falhamento. Em áreas tectonicamente ativas, a erosão na frente da escarpa formada pelo basculamento de blocos dá origem a vales estreitos e paralelos que podem proporcionar o aparecimento de feições triangulares nos interfluvios 
escarpados (Guerra \& Cunha, 1995). Feições como estas são comuns na área deste estudo.

O recuo da escarpa de falha pela erosão ou pela exumação de antigas linhas de falhas, onde uma nova escarpa é gerada não mais pelo deslocamento original, mas pela variação de resistência a meteorização das litologias adjacentes ao plano de falha, propicia o aparecimento de uma escarpa de linha de falha (Guerra \& Cunha, 1995).

Nas proximidades de Machado - MG, na Serra de Serrania, assinalam-se feições de relevos alongados de topos convexos, definindo interfluvios estreitos mas extensos, recobertos por coluvios. Também ocorrem escarpas reconhecidas como adaptadas a falhas ou escarpas de falhas, com feições de facetas trapezoidais nas bases. As escarpas de alguns morros mostram fissuras que aparentam o deslocamento de blocos, com elevação e/ou abatimento. Ocorrem feições tipo cristas que se destacam dos relevos mamelonares rebaixados, assim como ocorrências de matacões em áreas fechadas nos seus sopés (Radambrasil, 1983). Na área dos estudos foram identificadas estas feições.

Segundo Leinz \& Amaral (1985) montanhas ou elevações podem ser produzidas por falhamento, pela elevação de blocos em uma região baixa ou abatimento em áreas elevadas; ou ainda pode dar-se o levantamento geral dos blocos, um mais do que os outros, como também abaixamento irregular.

\section{6 -Influência da neotectônica na evolução da paisagem}

Trabalhos conduzidos no continente asiático (Gaoy et al.,1980; Michael et al., 1982; Lu , 1982; Liu et al.,1990; Amal et al.,1992; Kar, 1994), na América do Norte (Calvo, 1980; Sirkin et al., 1981; Retallak, 1983; Dubroeucq et al., 1992; Boun \& Kraus, 1993), na Europa ( Delgado Calvo Flores et al., 1982; Ergenzinger, 1988; FelixHenningsen, 1994) e na África (Becker, 1992; Alaily, 1993) destacam o papel da tectônica ressurgente na conformação da paisagem. 
No Brasil, Hasui \& Almeida (1978), Saadi (1990 e 1991), Schaefer (1996), Silva et al. (1997) e Marques Júnior et al. (1997) também dissertam sobre a influência da tectônica cenozóica no esculpimento do relevo.

A plataforma Sul Americana, consolidada pós o ciclo Brasiliano, começa a separar-se da placa Africana, no início do Jurássico. No Cretáceo, com a abertura do Oceano Atlântico, os movimentos tectônicos foram acentuados, decrescendo em intensidade até o Terciário (Mioto, 1990).

O ponto de partida da tectônica cenozóica seria a abertura do Atlântico Sul causando arqueamentos na costa do país. Após a distensão crustal a tectônica prosseguiu durante todo o Terciário e talvez Quaternário, caracterizando-se por várias pulsações e/ou variações de velocidade, sendo interrompida por períodos de relativa quiescência (Magalhães Júnior, 1990). A segunda fase tectônica, datada do Plio-Pleistoceno, teve caráter compressivo, sendo considerada fase intra placa (Hasui, 1990). O local preferencial para reativações mesocenozóicas foi o local onde desenvolveu-se a "Zona Rúptil Cássia-Barbacena" no Pré-Cambiano (Wernick et al., 1981).

Tectônica ressurgente é fenômeno denominado por Hills como manifestação tectônica intermitente de falhas em episódios separados por intervalos de quiescência (Hasui, 1990).

A abordagem da tectônica cenozóica tem, para Hasui e Almeida (1978), sua importância ligada aos marcantes reflexos de sua atuação na evolução morfodinâmica de uma área, já que o quadro geomorfológico reflete uma ação tectônica terciária seguida de um afeiçoamento no Quaternário.

Ribeiro e Saadi (1989) e Saadi (1991) descobriram falhamentos afetando sedimentos na região de São João Del Rei (MG), que demonstram o reativamento dos lineamentos pré-cambianos (como a Zona Rúptil Nova Resende-Barbacena) durante o Terciário Superior-Quaternário.

Schaefer (1996), expõe que latossolos e saprolitos têm sido intensivamente deslocados pela neotectônica Terciária/Quaternária, em áreas tectônicamente estáveis, como o Planalto de Viçosa. Isto também é particularmente observável em áreas afetadas pelos movimentos do último Terciário, ocorridos nas serras do Mar, da Mantiqueira e 
suas bordas, onde se localiza a região deste estudo. As principais evidências destes movimentos são a presença, nas linhas de falhas, de camadas de saprolito endurecidas, completamente estriadas e deformadas.

Silva et al. (1997) utilizaram aspectos pedogenéticos para entender, definir e identificar atividade tectônica atual/recente na região de Pirassununga (SP).

No Plioceno, a instabilidade tectônica afeta o conjunto da Plataforma Sul Americana como o indicam o espalhamento dos sedimentos da Formação Barreiras no Brasil e a reativação da compressão na Cordilheira dos Andes (Saadi, 1990a).

Hasui (1990) expõe que a influência de zonas de fraqueza crustal no desenvolvimento de processos e feições geológicas é reconhecida desde longa data. Ela vem merecendo atenção crescente por vir se revelando como fundamental para se entender o desenvolvimento de muitas feições geológicas no tempo e no espaço, inclusive das manifestações da neotectônica.

Durante o mapeamento sísmico do Sudeste do Brasil, Mioto (1990) observou que a ocorrência de sismos em regiões intraplaca tectônica (Plataforma Sul Americana, consolidada após o Ciclo Brasiliano) constitui uma das feições mais notáveis da atividade neotectônica, cujo entendimento é feito com elementos da geomorfogênese, fluxo geotérmico, descontinuidades geológicas, tensões intraplaca, dentre outros. Na região deste estudo é comum a ocorrência de sismos.

A zona transcorrente de Guaxupé (na qual está inserida a área deste estudo) definida como um grande bloco triangular com o vértice voltado para leste, apresenta esta forma devido a dois cinturões de transcorrência dúctil, estando o cinturão a norte (cinturão transcorrente de Campo do Meio) truncado por aquele a sul (cinturão transcorrente de Paraiba do Sul). O quadro regional desta estrutura pode ser vista pelo enfoque de um evento colísional oblíquo de grande expressão (Hasui et al., 1990a).

A zona tectônica de Campo do Meio (denominada por Wernick et al., 1981), que faz parte da Zona Rúptil Nova Resende-Barbacena, foi caracterizada como "área instável desde o Pré-Cambiano até o Terciário", com movimentação normal ou inversa das falhas principais (Saadi, 1990). 
A zona Rúptil Carandaí-Mogi Guaçu de Wernick et al. (1981) também chamada de cinturão de Cizalhamento Ouro Fino, é composta de várias falhas transcorrentes e inversas, com reativações envolvendo ação hidrotermal (Saadi, 1990).

A importância do Cinturão de Cizalhamento Ouro Fino e da Zona Rúptil Nova Resende - Barbacena no condicionamento do relevo de forma ativa foi reconhecido por Saadi (1991).

Os cinturões de cizalhamento compreendem um feixe de falhas, fraturas e suturas. A sutura Alterosa (NW-SE), se conectada à de Ubatuba (NE-SW), permitirá restabelecer uma junção tríplice no Centro-Sul de Minas Gerais, já que nesta região a sutura de Alfenas e Itumbiara se articulam com a sutura Ribeirão Preto. Este arranjo leva a interpretação de que estas suturas são resultantes de colisão de blocos e se acham justapostas por zonas de subducção (Mioto, 1990).

A zona sismogênica de Passos é delimitada a oeste pelas suturas Itumbiara e Alterosa, ao sul e a leste pelas zonas sismogênicas de Caxambu e Bom Sucesso e a norte pelo soerguimento do Alto Paranaíba. Os sismos desta zona ocorreram em Varginha, Alfenas, Passos e Araxá (Mioto, 1990).

Mioto (1984) expõe que "os estudos sobre sismicidade no sudeste brasileiro, desde o início do século, mostram que as ocorrências dos eventos sísmicos refletem uma tectônica residual, com acomodação final dos blocos movidos no Terciário". Para Saadi (1991) "as relações entre sismicidade e estruturas tectônicas permitem avançar na detecção e/ou confirmação das estruturas atualmente ativas".

Dados recentes coletados na Estação Sismológica de Brasilia indicam registros de abalos sísmicos no Centro -Sul e Sudeste de Minas Gerais nos anos de 1990, 1991, 1992, 1994 e 1996. O abalo de 1992 teve seu epicentro em Areado e alcançou 2,8 ${ }^{\circ}$ na escala Richter. Em 1996 foram registrados abalos a 15 de setembro (com epicentro em Alfenas ) e a 19 de outubro, sendo que o último alcançou magnitude entre 3,5 e $4^{\circ}$ na escala Richter e foi percebido em várias cidades da região. Vários pesquisadores atribuem este fenômeno a um feixe de falhas geológicas existentes na região. 


\section{7 - Questões de Pedogênese em áreas cratônicas do Pré-Cambriano}

Existem muitas questões pedogenéticas nos trópicos pouco elucidadas e diversas tentativas de preencher estas lacunas têm sido realizadas. Dentre elas podem ser citadas: a) Os estudos sobre a gênese dos latossolos e seus microagregados, a ocorrência dos mesmos em todas as posições da encosta; inclusive em áreas com declives superiores a $20 \%$; b) gênese do horizonte $\mathrm{B}$ textural dos podzólicos; c) influência da tectônica na

gênese e distribuição dos solos; d) origem e pedogênese das linhas de pedra ou "stonelines"; e) a influência do material subjacente e do material retrabalhado depositado localmente nos solos ( autoctonismo e aloctonismo ) e a contribuição da fauna do solo nestes processos ; f) gênese do horizonte $\mathrm{A}$ húmico. Estas indagações, que podem ser extrapoladas para uma ampla região do Brasil Sudeste, estão incluídas neste estudo.

\subsection{1 - Gênese de Latossolos}

Latossolos são solos profundos, bem a acentuadamente drenados de textura média a muito argilosa apresentando um horizonte B latossólico intemperizado, caracterizado pela quase total ausência de minerais primários facilmente intemperizáveis e/ou de minerais de argila 2:1 e pela concentração residual de sesquióxidos, argila do tipo 1:1 e minerais primários resistentes ao intemperismo ( Embrapa, 1981; Radambrasil, 1983; Camargo et al., 1987; Carvalho et al., 1988). Correspondem aos Oxisolos da classificação norteamericana de solos (EUA, 1975). Ocorrem principalmente nas regiões tropicais úmidas, com mais frequência nas partes mais antigas (há muito tempo expostas) da paisagem (Resende, 1982). A ocorrência destes solos em regimes hídricos semi-áridos ou fora da região tropical é atribuída geralmente a paleoclimas mais úmidos e/ou quentes, estando os oxisols sob superficies estáveis, remanescentes destes períodos (Allen e Fanning, 1983; Sanchez, 1981). 
Latossolo "senso stricto"pode ser obtido somente a partir de materiais de idade mais avançada que cretácica. Tendo sido formados desde o Terciário, estes latossolos podem ser considerados como paleossolos expostos (Schaefer, 1996).

Para Lucas et al. (1993) latossolos são muito antigos, com tempo de formação, considerando as condições atuais, entre 10 a 100 milhões de anos. Estes autores expõem que pelo menos nos últimos 10 milhões de anos não ocorreram, em regiões dos velhos escudos estáveis, episódios climáticos que permitissem a ablação da cobertura dos solos, como geleiras ou desertos quentes.

Latossolos são solos muito profundos, podendo ultrapassar $30 \mathrm{~m}$ de profundidade, onde são encontrados canais biológicos de origem desconhecida e que são usualmente preenchidos por material de solo proveniente dos horizontes superiores. Alguns são chamados pedotúbulos (Rezende, 1980 ; Resende et al. , 1995), similares àqueles descritos por Brewer (1964). Estes túbulos podem estar preenchidos com gibbsita ou com caulinita ligada a óxidos de ferro ou ainda podem ser considerados traços de raízes, de "paleominhocas", ou canais de térmitas (Schaefer, 1996).

Até o Terciário médio a vegetação dominante era composta por coníferas. A partir deste período, as gramíneas, originadas no Eoceno, se diversificaram e expandiram, coincidindo com a explosão populacional e expansão areal dos térmitas. Estes podem ter sido os principais fatores responsáveis pela gênese dos latossolos e a criação de sua microestrutura (Schaefer, 1996).

Estes solos são formados pela latolização, ou seja, remoção de silica e bases do perfil (Buckman \& Brady, 1968; Resende, 1982; Birkeland, 1984). Ocorre migração de silica e bases do perfil e acúmulo residual de sesquióxidos (gibbsita, goethita, hematita, etc) no solum, com ou sem formação de plintita ou concreção de ferro (Buol et al., 1980).

Apesar de vários autores se referirem a estes solos como os componentes das superficies mais elevadas e/ou preservadas da paisagem, que são as mais antigas (Lepsch, 1977b; Chauvel et al., 1978; Stoops \& Buol, 1985; Lepsch \& Buol, 1986; Santos et al., 1991; Vidal Torrado \& Lepsch, 1993; Vidal Torrado, 1994); cabe salientar que os latossolos podem ser formados de materiais pré-intemperizados, transportados de outras 
áreas da paisagem (Sanchez, 1981; Birkeland, 1984, Vidal Torrado, 1994) não sendo, portanto, tão antigos. $\mathrm{Na}$ área de estudos, Camargo et al., (1962) levantaram a hipótese dos latossolos serem formados de material já meteorizado, provenientes de xistos, filitos, filonitos e outras rochas do Complexo Andrelândia. Lichte, (1990 e 1991) argumenta que os latossolos podem ser formados por uma mistura de material retrabalhado com sedimentos de origem eólica.

A macroestrutura dos latossolos é comumente granular ou grumosa. As estruturas granular e grumosa são compostas respectivamente por agregados menores que $1 \mathrm{~mm}$ e $2 \mathrm{~mm}$. As organizações interna e externa dos agregados granulares testemunham sua origem biológica: forma externa esférica ou oval, subestrutura em microagregados esféricos ou ovais, presença de micropartículas ovais de carvão e esqueleto externo triado. Estes agregados são idênticos àqueles elaborados por cupins e formigas. Os agregados grumosos correspondem a dejeção de minhocas, que se solidificam à medida que perdem umidade (Miklós, 1996).

Latossolos formados de rochas máficas, mais gibbsíticos, mostram uma melhor agregação. Latossolos cauliníticos são normalmente menos microagregados, com as partículas granulares menos arredondadas e mais parecidas com blocos (Schaefer, 1996).

Resende (1976 ), estudando latossolos do Planalto Central do Brasil, observou que a relação caulinita/gibbsita tende a ser mais elevada em solos sob cerrado do que em solos sob floresta. As hipóteses aventadas para explicar esta constatação foram o baixo regime de matéria orgânica do solo, as elevadas precipitações e a presença de solos sob cerrado em antigas superfícies de aplainamento. Lucas et al. (1993) atribuem o predomínio da caulinita sobre a gibbsita em solos da Amazônia a intensa reciclagem de silício pela vegetação florestal, favorecendo a estabilidade da caulinita, mesmo em ambiente altamente intemperizado.

Vidal Torrado (1994) observou que morfologicamente muitos latossolos são peculiares por apresentarem horizonte B onde a maior parte do plasma está contido em microagregados.

Para Stoops (1983) os microagregados dos Oxisolos podem ter sido originados de diferentes maneiras. 
A partir de revisão feita em trabalhos de Muller (1977 e 1981), Stoops \& Buol (1985) expõem que os microagregados de latossolos podem se originar por estruturação (estrutural), pela ação da fauna (zoogenético), por herança do material de origem (reliquial), pela ação da geoquímica (geoquímico) ou por complexação (complexo).

Os microagregados estruturais são formados a partir de microfissuração de plasma adensado (Stoops \& Buol, 1985). Formigas e cupins ingerem partículas e posteriormente as regurgitam e/ou defecam, originando os microagregados zoogenéticos, Miklós (1992 e 1993). O retrabalhamento de materiais pode originar os microagregados reliquiais (Muller, 1977). A origem dos microagregados geoquímicos está relacionada a redistribuição de óxidos de ferro e microagregados complexos resultam da união de microagregados menores (Stoops \& Buol, 1985).

Conclusões opostas sobre o tempo de pedogênese foram obtidas por Pellerin \& Queiroz Neto (1992) estudando horizonte de latossolo de Marilia (SP) e por Boulet et al. (1992) estudando a cobertura pedológica do conjunto cárstico de Pedro Leopoldo (MG). Os primeiros expõem que a formação do horizonte microagregado latossolico se deu numa fase de pedogênese posterior ao entalhamento da vertente atual e os últimos afirmam que a formação de cobertura latossolica espessa de topo necessitou de muito tempo e que sua pedogênese se deu provavelmente antes do que os solos à juzante.

Pesquisas feitas por Beadou (te)al. (1972) em solos ferralíticos da República Centro-Africana salientam que a gênese dos microagregados está intimamente ligada à pedogênese ferralitica. Os microagregados apresentam uma estrutura complexa composta por um núcleo rico em óxidos e hidróxidos de ferro, envolvido por uma camada de fundo matricial pouco modificado. São formados pela modificação do plasma que pouco a pouco vai se individualizando e passa de massético para insético ou assético. A porosidade fissural passa a porosidade de empilhamento à medida que os microagregados vão se individualizando. Em novos estudos na mesma área, Beadou et al. (1987) observaram que os microagregados resultam da combinação de argilas com hematita e que as argilas estão orientadas paralelamente às bordas dos agregados.

Cambier (1986) citado por Pedro (1987) verificou que nos oxissolos os cristalitos de caulinita estão dispostos paralelamente e ligados entre sí por pontes de 
ferro, formando os policristalitos, que originam as unidades chamadas de microdomínios (lum) característicos. Estes, por sua vez, são a base para a formação dos micronódulos característicos dos oxissolos.

Santos et al. (1989) estudando seções ultra delgadas através de técnicas de submicroscopia observaram que os microagregados são constituídos predominantemente por caulinita pouco cristalina, empacotada e orientada ao acaso. Oxi-hidróxidos de ferro pouco cristalinos (provavelmente ferridrita) ocorrem como agregados individuais preenchendo o espaço entre as partículas de caulinita e a matéria orgânica atua como elemento de ligação entre as partículas de argila. Esta combinação confere aos microagregados natureza anisotrópica.

A formação de microagregados se dá a partir de uma matriz anisotrópica composta de caulinita e hidratos de ferro. Zonas pequenas (100um) estariam se formando nesta matriz, como resultado de uma organização diferencial do ferro. Estes micronódulos se individualizariam quando a matriz que os circunda desaparece devido à sua alta mobilidade, resultante da deferrificação parcial (Chauvel, 1978 citado por Stoops, 1983).

Estudos comparativos realizados em amostras indeformadas de microagregados coletadas de latossolos no campo e em amostras de microagregados obtidos em laboratório, ambas produzidas por cupins, foram levadas a cabo por Eschenbrenner (1986) no Congo, África. Este pesquisador observou que os microagregados eram orgânicos, minerais ou organo-minerais e que apresentavam forma oval ou esférica. Como os microagregados das amostras coletadas no campo eram similares aos microagregados do material produzido em laboratório, o autor concluiu que os microagregados encontrados nos latossolos podem ser resultantes da atividade de cupins em condições tropicais; processo denominado por ele como bioagregação.

Outros trabalhos também demonstraram o papel da fauna do solo na formação de microagregados (Chauvel, 1977; Muller, 1977; Stoops, 1983; Trapnell \& Webster, 1986). No Brasil pesquisas com este enfoque ainda são incipientes; mas Miklós (1992 e 1993) estudando solos formados sobre basalto em Botucatu (SP), concluiu que formigas e cupins são os principais responsáveis pela formação dos microagregados. O mesmo 
embasou sua conclusão nos seguintes fatos: a aptidão dos animais em fabricar microagregados ovais; a forma oval dos microagregados de latossolos; a presença de micropartículas de carvão; o esqueleto interno triado, composto por grãos de quartzo inferiores a 100um; a presença de orientações plásmicas periféricas e a identidade que existe entre os microagregados que se encontram nos latossolos e aqueles produzidos pela fauna do solo no interior de biotúbulos e nos montículos de terra dos formigueiros e cupinzeiros.

Um outro enfoque para explicar a formação de microestrutra oval dos agregados de latossolos foi dado por Pedro et al. (1987). Ele expõe que os mesmos são formados por um estágio inicial de alteração ferralítica com neoformação de um material ferrocaulinítico e por um estágio final que corresponde ao desenvolvimento de um horizonte microagregado típico devido ao total desaparecimento dos minerais primários da rocha e da individualização de um complexo de alteração essencialmente caulinogibbsítico, além da ocorrência de fenômenos secundários como a dessaturação do complexo de adsorção, a ferritização do complexo argiloso, e de uma cristalização progressiva dos compostos ferriferos independentes.

Dormaar et al. (1991), estudando a formação de agregados na rizosfera de gramíneas no Canadá, verificou que microagregados são formados pela fusão de poligorskita revestida por bactérias, colônias e células remanescentes; e que os agregados permanecem estáveis mesmo após a morte das bactérias.

A formação de microagregados é favorecida pela presença da gibbsita e em menor proporção, por óxidos de ferro. A gibbsita pode atuar como um núcleo responsável pela formação da micropartícula, mas ela sozinha não pode formar a microestrutura de latossolos (Schaefer, 1996).

Vidal Torrado (1994) estudando topossequências no distrito de Tupi, em Piracicaba (SP), observou que a formação de microagregados é complexa e deve ter ocorrido por mais de um processo. O mesmo identificou microagregados formados por microestruturação, por ação de fauna e outros herdados do retrabalhamento do material latossolico ocorrido na evolução do vale. 


\subsection{2 - Latossolos Húmicos}

Latossolos Húmicos são solos que se diferenciam dos demais latossolos por apresentarem horizonte A húmico, definido por Carvalho et al. (1988) e Embrapa (1981) como horizonte com cores mais escuras (valores e cromas menores que 3,5), com medianos a elevados teores de matéria orgânica em profundidade (maior que 1\%) e espessura maior que $80 \mathrm{~cm}$. Para Melo (1994), a matéria orgânica tende a atribuir aos solos matrizes mais escuras. Corresponde ao epipédon umbric da "Soil Taxonomy" (EUA,1975). Estes solos são comumente encontrados na área enfocada por esta pesquisa, ocorrendo tanto nas superficies mais rebaixadas e aplainadas da paisagem como nas superficies mais elevadas e dissecadas.

Queiróz Neto \& Castro (1974) encontraram latossolos húmicos em colinas elongadas e rebaixadas na região de Bragança Paulista (SP), que está localizada dentro da cadeia de montanhas da Mantiqueira e que é adjacente a área deste estudo. Eles relacionaram estes solos com a superfície Pd1, originada por fases de pedimentação do Pleistoceno.

Carvalho \& Rotta (1974), encontraram latossolos húmicos com pequeno gradiente textural no município de Atibaia (SP), que também se insere na região da Serra da Mantiqueira. Eles associaram estes solos a materiais argilosos remanejados, espessos e de coloração vermelho amareladas.

De acordo com Carvalho et al. (1975) estes latossolos húmicos possuem horizonte A húmico com espessura entre 140 e $200 \mathrm{~cm}$ e horizonte $\mathrm{Bw}$ com cores vermelho amareladas. São solos argilosos e seus teores de argila aumentam com a profundidade. Ocorrem em cotas entre 800 e $900 \mathrm{~m}$, onde os declives oscilam entre 6 e $16 \%$. Estes solos guardam muitas semelhanças com os latossolos húmicos encontrados na área deste estudo. Cabe salientar que tanto os municípios de Atibaia e Bragança Paulista como a região destes estudos se localizam próximas às bordas da Serra da Mantiqueira. 
Em áreas elevadas do leste de Minas Gerais, Embrapa (1981) mapeou grandes extensões de latossolos húmicos. Radambrasil (1983) encontrou grandes manchas destes solos no centro-oeste do Rio de Janeiro e no leste do Espírito Santo.

Para Lepsch \& Buol (1986) os latossolos húmicos são comuns em paisagens das "Cordilheiras do Mar e da Mantiqueira". Porém a gênese destes solos não é completamente entendida. De acordo com estes autores, o epipedon úmbrico destes solos (horizonte A húmico) poderia ser um aspecto reliquial derivado de uma forma única de condições ambientais favoráveis ao acúmulo de matéria orgânica a grande profundidade e sua manutenção seria devida a estabilidade da superficie Pdl e a formação de complexos humus-argila.

Modenesi-Gautieri et al. (1996) escreve sobre climas mais frios e secos no maciço do Itatiaia (Serra da Mantiqueira) no final do Pleistoceno, o que contribuiria para a manutenção da matéria orgânica no solo. De acordo com Dabin (1976) solos sob clima tropical, com diferença de temperatura entre o dia e a noite podem apresentar acúmulo de matéria orgânica. $\mathrm{Na}$ região em pauta, nas madrugadas de inverno, não raramente as temperaturas chegam a $\mathrm{O}^{\circ}$ Célsius.

A ligação de partículas de argila a humus em Oxisolos é atribuída por Stevenson (1982) ao compartilhamento de forças iônicas entre as argilas e a pontes ligando humus a argilas e a cátions polivalentes, formando complexos humus-metal-argila. A fração humus do solo é considerada por Miyasaka et al. (1983), uma mistura complexa e muito resistente, constituída por substâncias amorfas, castanhas ou castanho-escuras, que foram modificadas bioquimicamente a partir de tecidos ou sintetizadas pelos organismos do solo.

Stevenson (1982) classifica a matéria orgânica humificada, baseando-se em características de solubilidade, em quatro categorias: ácidos húmicos, ácidos fúlvicos, ácidos hematomelânicos e humina. Esta última é sintetizada principalmente a partir da lignina (Melo, 1994) e é muito resistente a decomposição. A matéria orgânica estabilizada quimicamente tem, segundo Siqueira \& Franco (1988), uma taxa de permanencia no solo em torno de 2850 anos. 
Volkoff et al. (1978), trabalhando com fracionamento de matéria orgânica de latossolos distróficos da Bahia, obteve que na superfície a mineralização dos detritos vegetais é sempre rápida. Os produtos pré-húmicos, formados no decorrer da mineralização, migram facilmente em profundidade e parte deles dá origem a ácidos fúlvicos, adsorvidos nas argilas ou complexados com o alumínio. Outra parte se precipita, transformando-se em ácidos húmicos e humina, esta última a fração mais resistente a degradação.

Um aspecto corriqueiro na maioria dos latossolos húmicos são os fragmentos de carvão encontrados com abundância a até varios metros de profundidade.

Sanford et al. (1985) coletaram amostras de carvão desde a superficie até a $70 \mathrm{~cm}$, em vários solos da Amazônia, com diferentes coberturas vegetais. As datações destes fragmentos pelo método do $\mathrm{C}^{14}$ revelaram idades entre 200 e 600 anos na camada de $\quad(0-20 \mathrm{~cm})$ aumentando em profundidade. A origem deste carvão está relacionada a grandes incêndios ocorridos em 4 fases secas ( a última entre 700 e 400 anos atrás) e a atividade antrópica. Estes pesquisadores também argumentam que, mesmo em locais de elevado índice de precipitação pluviométrica o ano todo, o fogo é capaz de queimar pequenas partes da floresta.

Soubiés (1980) datou carvões obtidos em solos da Amazônia, entre 3000 e 6000 anos e relacionou a origem dos mesmos a fases de clima seco. Sua presença em profundidade foi considerada como devida a atividade da fauna do solo. Lucas et al. (1993) encontraram fragmentos de carvão concentrados entre 50 e $100 \mathrm{~cm}$ de profundidade, ao longo da rodovia Cuiabá-Santarém e ligaram sua origem a grandes incêndios ocorridos entre 3000 e 6000 anos atrás na paleocobertura vegetal.

Absy et al. (1993) identificaram, através de estudos palinológicos, mudanças na composição florística da vegetação da Amazônia nos últimos 50000 anos e relacionaram savanas a períodos secos, onde eram mais intensos os incêndios que produziram os carvões. Para estes autores os períodos secos, também observados em outras partes da América do Sul, parecem ser um fenômeno de grande amplitude regional.

Em trabalho conduzido por Boulet et al. (1995) no triângulo mineiro, também é atribuída a incêndios a origem dos fragmentos de carvão encontrados a até 2 metros de 
profundidade em um oxisol com estrutura microgranular, que ocupa as posições de topo, ombro e meia-encosta de uma vertente. As datações deste material $\left(\mathrm{C}^{14}\right)$ revelam idades entre 150 (na camada de 0-10 cm) e 8500 anos (na camada de 190-200 cm), aumentando com a profundidade. A hipótese de coluvionamento foi descartada, pela ausência de materiais acima da posição de topo. A presença de carvão a grandes profundidades foi interpretada como sendo causada pelo remonte vertical, levado a cabo pela fauna do solo.

Para Melo (1994) a preservação de carvão pode estar relacionada a ausência de mineralização em condições anaeróbicas.

O reconhecimento de efeitos bióticos no desenvolvimento de solos tropicais a longo prazo tem sido amplamente reportado na literatura. Johnson (1990), tem proposto a evolução do biomanto como um processo amplamente responsável pela distribuição de materiais terrosos. Então, biomantos são zonas diferenciadas na parte superior dos solos (horizonte A), produzida grandemente pela ação de revolvimento promovida pela biota, auxiliada por processos subsidiários (Schaefer, 1996).

O horizonte $\mathrm{A}$ húmico pode ser formado em etapa posterior a gênese do horizonte sômbrico (Horizonte escuro, enterrado). A origem dos horizontes sômbricos encontrados em Botucatu (SP) foi atribuída por Miklós (1993), como devida ao soterramento por remonte vertical realizado pela fauna do solo. Através de datação $\left(\mathrm{C}^{14}\right)$ de fragmentos de carvão vegetal localizados no interior destes horizontes, Miklós (1992) obteve que em 4.400 anos (idade do carvão) a fauna do solo remontou 12.000 ton/ha; o que equivale a um perfil de solo de 1,5 a $2,0 \mathrm{~m}$ de profundidade. Boulet et al. (1995) obteve uma taxa de remonte entre 0,21 e $0,23 \mathrm{~mm} /$ ano.

\subsection{3 - Latossolos em relevo movimentado}

$\mathrm{Na}$ área em apreço, associaç̃es aparentemente antagônicas, como latossolos (solos muito intemperizados e desenvolvidos) e afloramentos de rochas (que normalmente estão associados a solos pouco desenvolvidos como os litólicos) ocorrem comumente. Outro aspecto comum desta paisagem são latossolos ocupando vertentes de 
elevada declividade; discordando da maioria dos modelos de distribuição de solos na paisagem, para os quais os latossolos ocupariam as posições mais suavizadas de uma encosta, transicionando para solos com horizonte B textural ou solos pouco desenvolvidos onde os declives são mais elevados.

Para Resende (1982) parece lógico pensar que em muitas áreas do Planalto Atlântico, onde o relevo é acidentado, ele já tenha sido mais suave, com solos bastantes velhos (latossolos), cujo material foi, em parte, redistribuído pelas vertentes. Nesta situação, pode-se inferir que a erosão que causou o recuo das vertentes e entalhou o relevo não foi suficiente para carrear todo o material já intemperizado; permanecendo latossolos mesmo em posições de elevada declividade.

Este mesmo autor expõe que quando o material do origem já foi muito intemperizado, antes do ciclo atual de pedogênese, pode-se ter solos muito velhos, mesmo num relevo acidentado e de pedoforma bastante ravinada (expressão de uma fase de revejunescimento atual), como é o caso de considerável área do Brasil Sudeste.

Além de Chapadões e áreas suaves, sob cerrado ou floresta, os latossolos ocorrem também em áreas acidentadas, mas com poucos afloramentos de rochas em grande parte do Sul e Sudeste do Brasil, numa faixa de largura variável. Adaptado de Resende et al. (1988).

Camargo et al. (1962) mapeando os solos da região sob influência do reservatório de Furnas (MG) a nível de reconhecimento, constatou serem muitos raros, praticamente inexistentes, afloramentos de rocha nas áreas desta unidade, o que dificulta a identificação da natureza do embasamento rochoso destes solos. Tal constatação não vem de encontro a observações feitas por outros pesquisadores como Vidal Torrado, Sparovek e Silva na mesma região, talvez pelo nível de detalhamento (reconhecimento) utilizado no mapeamento referido anteriormente.

Por outro lado, Camargo et al. (1962) verificaram que, independente do substrato rochoso, ocorre na região uma deposição de natureza argilosa por vezes de caráter bem distinto da formação rochosa subjacente. Para este autor este capeamento possivelmente origina-se de material que sofreu meteorização em épocas anteriores. Lichte (1990 e 1991), estudando a coberura argilosa de uma área adjacente e afim em 
clima, topografia e litologia, concluiu que esta cobertura provém de uma mistura de material transportado pela água a partir de áreas mais elevadas com material de origem eólica.

\subsection{4 - Ação da fauna do solo na gênese de latossolos}

A contribuição da fauna do solo na transformação da cobertura pedológica corresponde a fenômenos que abrangem diversas escalas, do microagregado à paisagem. Formigas e cupins são os principais responsáveis pela formação de microagregados no horizonte Bw de latossolos, pela organização atual de linhas de pedras e pela gênese de horizontes sômbricos por remonte vertical de material para a superficie. Esta contribuição se dá devido ao hábito alimentar e construtor desta fauna (Miklós,1996).

No geral, a maior produtividade animal da biosfera é da pedofauna, que pode atingir mais de uma tonelada/ha e representar 15 vezes a biomassa dos homens sobre a terra (Bacheler, 1978).

Os térmitas dominam (em densidade e biomassa), a fauna dos solos tropicais (Lee \& Wood, 1971; Bacheler, 1978; Wood \& Sands,1978; Grasse, 1984 e 1986). Seus principais efeitos no solo advém de sua conduta escavadora ; além de sua habilidade de digerir tecidos de plantas (Eschenbrenner, 1996) e de degradar a lignina através de um microorganismo de sua flora intestinal (Melo, 1994).

Desde meados deste século que autores como Griffithi (1953), Swartt (1964) e Millot (1964), reconhecem a importância da atividade de cupins e formigas na formação de latossolos. Para Lovelock (1979), a grande atividade de térmitas nos tropicos leva a conversão de saprolito em matriz de solo bem estruturada e que as satisfatórias propriedades físicas dos latossolos estão associadas com atividade de cupins e formigas.

Frequentemente latossolos são correlacionados com superficies antigas e estáveis, propícias a ação da fauna do solo. A presença de tipos similares de latossolos e de superficies de aplainamento em ambos os lados do Atlântico Sul é um forte indicativo da ação biótica de longo prazo (Shaefer, 1996). 
Schaefer (1996) revisando a literatura sobre a origem dos térmitas, concluiu que na maior parte das áreas tropicais, espécies de térmitas podem existir desde o Terciário médio ou até em períodos anteriores. Grasse (1986) expõe que todos os grupos de térmitas encontrados desde os dias atuais existem desde o Paleoceno/Eoceno.

Para Martinez-Delcos \& Martinell (1995) os cupins existem pelo menos desde 0 Cretáceo superior, ou seja, desde a 130-135 milhões de anos . Então, a probabilidade de influência destes animais na formação dos solos, no passado e no presente, é muito grande, particularmente nos latossolos que cobrem extensas áreas tropicais (Eschenbrenner, 1996).

Lee \& Wood (1971) expõem que os térmitas de montículo são capazes de translocar 62 toneladas de solo por hectare pora construção de suas moradias. No norte da Amazônia, Salik et al. (1983) mediu uma taxa de ciclagem de nutrientes por cupins de 0,78 toneladas por ano.

Miklós (1996), revisando a literatura, encontrou os seguintes dados de densidade populacional: 12 a 1730 minhocas $/ \mathrm{m}^{2}, 1000$ a 1110 térmitas $/ \mathrm{m}^{2}$ e 300 formigas $/ \mathrm{m}^{2}$; podendo consumir respectivamente 1,25 ton de matéria seca /ano , 6 a 7 ton de matéria orgânica /ano e em torno de 4 ton de capim por hectare por ano. Em relação ao remonte vertical, este mesmo autor encontrou na literatura e através de estimativas próprias, que os cupins remontam 0,34 a $40 \mathrm{~mm}$ de material /ano, as saúvas de 0,09 a $0,22 \mathrm{~mm} / \mathrm{hectare} /$ ano e que as minhocas podem ingerir 500 a 3120 ton de terra por hectare em um ano.

Estudos sobre a biodinâmica da paisagem foram realizados por Miklós (1992) em Botucatu-SP e a taxa de remonte vertical de materiais do solo pela fauna foi calculada e 0,21 a $0,34 \mathrm{~mm} / \mathrm{ano}$. Boulet et al. (1995) obtiveram taxas de remonte entre 0,21 e $0,23 \mathrm{~mm} / \mathrm{ano}$, em oxisolos muito argilosos do triângulo mineiro.

O efeito dos térmitas na morfologia do perfil do solo e na fábrica do solo é sumarizado na seguinte forma: pedoplasmação da zona do saprolito; contribuição para a individualização de glébulas e para o deslocamento de seixos no subsolo; contribuição para a depleção de argila dos horizontes superficiais (Eschenbrenner,1996). Flach et al. (1968) definiram pedoplasmação como um processo fisico primário que transforma rocha 
intemperizada (saprolito) em horizonte B. Para buscar água, os cupins escavam canais que podem atingir o saprolito, seguido de preenchimento dos canais e galerias com material microagregado. A sucessão de escavamentos e preenchimentos leva a "biopedoplasmação". A atuação dos térmitas na concentração de seixos no subsolo pode ser descrita pelo transporte de materiais mais finos para os horizontes superiores, o que leva a uma concentração de materiais grosseiros no subsolo; juntamente com a descida destes seixos pelo perfil devido a construção de um grande número de canais e galerias (Eschenbrenner,1996).

Para explicar a depleção de argilas do horizonte superficial (muito comum em latossolos brasileiros e particularmente da região dos estudos), Eschenbrenner (1986 e 1988), demonstrou que os térmitas podem carrear material mais fino para camadas inferiores do perfil e que o material utilizado para a construção dos cupinzeiros pode ser quebrado pelo embate da gota de chuva, sendo que os mais finos são transportados pela enxurrada $e$ os mais grosseiros permanecem na superfície, concentrando-se residualmente.

A atividade dos térmitas (cupins), também pode levar a transporte de materiais para as partes mais profundas do perfil, como fragmentos de rocha ou como materiais argilosos. Estes movimentos podem explicar em parte a origem de algumas linhas de pedras e o elevado grau de homogeneidade verificado no solo (Schaefer,1996).

Os térmitas utilizam a hipofaringe (órgão móvel e eréctil da cavidade bucal) como uma língua para moldar pellets de materiais com diâmetro entre 0,2 e $2 \mathrm{~mm}$ dentro do cibarium (parte superior da cavidade bucal). Este órgão também é usado para modificar, pelo efeito de pressão, a forma e plasticidade dos materiais, e também como uma ferramenta de polimento. Estes animais transportam materiais escavados de duas formas: nas mandíbulas e dentro da cavidade bucal ou do corpo. Com as mandíbulas podem transportar material do tamanho de areia grossa a cascalho fino. Argila, silte e areia fina são transportados dentro da cavidade bucal ou do corpo e depositados respectivamente por regurgitação e excreção (Eschenbrenner, 1996). 


\subsection{5 - Gênese dos Podzólicos}

Solos podzólicos são caracterizados pela presença de horizonte B textural, que na "Soil Taxonomy" (Eua, 1975) á denominado horizonte argílico. O mesmo é um horizonte mineral subsuperficial caracterizado por apresentar um incremento no teor de argila, desde que não exclusivamente por descontinuidade litológica, ou seja, o conteúdo de argila do B textural é sempre superior ao do horizonte A e pode ou não ser maior do que o horizonte C. (Embrapa, 1981; Radambrasil, 1983; Camargo et al., 1987; Carvalho et al., 1988).

De acordo com Vidal Torrado (1994) os processos mais importantes e que levam à formação de gradiente textural entre os horizontes $\mathrm{A}$ e $\mathrm{B}$ são: migração de argilas (argiluviação) ou destruição de argilas da camada superficial, herança litológica e coluvionamento por material mais grosseiro.

A argiluviação também chamada de podzolização por Resende (1982) e de lessivagem por Buol et al. (1980), consiste na translocação de argilas em solução ou em suspensão dos horizontes A e/ou E para o horizonte B (Birkerland, 1984) e é influenciada pelos teores e tipos de colóides do solo, pela natureza e concentração dos eletrólitos, pela atividade das argilas e pelo fluxo de água no solo (EUA, 1975; Birkeland, 1974 e 1984; Eswaran \& Sys, 1979; Buol et al., 1980; Nettleton et al., 1987). Os trabalhos de Lepsch et al. (1977b) e de Queiróz Neto (1981) enfatizam o favorecimento da mobilidade das argilas pela destruição das ligações ferro-argila.

As condições básicas para a ocorrencia de argiluviação são, de acordo com Eswaran e Sys (1979) as seguintes: as argilas devem estar em condições de dispersar-se no horizonte eluvial; o fluxo de água no solo deve ser periódico; o horizonte subsuperficial deve estar em condições de receber as argilas e a pedoturbação não deve ser suficiente para destruir os depósitos de argila.

A argiluviação é evidenciada pela formação de ferriargilãs finos ( lepto-coatings) nos poros do horizonte B nito-argílico (Sombroek, 1980). A ocorrência de superficie lisa e polida, usualmente denominada de cerosidade, devido a argiluviação é pouco provável, 
não só pela sua ocorrência em partes profundas dos perfis, como pela sua composição (Sombroek \& Sidérius, 1976).

Isbell (1980), revisando a literatura sobre horizonte $\mathrm{Bt}$, nem sempre encontrou relação entre a cerosidade encontrada no campo e a quantidade de cutãs de iluviação encontrados em lâminas delgadas.

Nettleton et al. (1992) afirmam que para a caracterização de um horizonte argílico deve haver a presença de cutãs de iluviação, evidenciados pela deposição em camadas nas paredes dos poros e vesículas.

Em solos com elevada relação textural, a diferença na porosidade entre os horizontes superficiais e o horizonte B textural, pode causar um hidromorfismo nesta transição; levando a uma degradação de argilas no topo do horizonte Bt. Brinkman (1969/1970) denominou este processo de ferrólise, ou seja, hidromorfia em meio ácido causando destruição de argilas. No Brasil, Berg et al. (1987); Castro (1989); Jimenez Rueda \& Demattê (1988) e Vidal Torrado (1991) identificaram este processo como de grande importância na formação de solos com Bt.

O gradiente textural pode ainda ser herdado da estratigrafia da rocha mãe (Jimenez Rueda \& Demattê, 1988).

A presença de agregados na forma de prismas e blocos em solos com horizonte $B$ textural é comum e está relacionada a ciclos de umedecimento e secagem pois estes causam retenção da massa do solo, cimentação das partículas e o segmento de planos de tensão fraturados que formam o limite das unidades estruturais (Gavande, 1976; Write, 1967).

Concomitantemente a migração de argilas promove a ligação entre microagregados favorecendo a formação de agregados maiores. (Vidal Torrado et al., 1995; Vidal Torrado, 1994).

Estudando uma topossequência em Itatiba (SP), Moniz \& Buol (1982) verificam que a medida que a vertente se forma devido a uma mudança do nível de base, o processo de fluxo lateral de água começa a funcionar. Como consequência os horizontes próximos à superficie sofrem compressão devido a ciclos alternados de saturação e dissecação, o 
que vai resultar na formação de horizontes argilicos com estrutura em blocos e de maior densidade do solo.

\subsection{6 - Transição entre Solos com Bw para Solos com Bt}

A transição entre latossolos e podzólicos encosta abaixo é frequente na paisagem tropical e também ocorre, embora em menor frequência, na área em questão. Vidal Torrado (1989 e 1994), considerando, dentre outros, trabalhos de Lepsch \& Buol (1975); Lepsch et al. (1977b); Queiroz Neto et al. (1981); Moniz \& Buol (1982); Castro (1989); Miklós (1992) e Vidal Torrado \& Lepsch (1993), agrupou as hipóteses da passagem de solos com Bw para solos com Bt encosta abaixo da seguinte maneira:

a) Transformação do horizonte $\mathrm{Bw}$ em $\mathrm{Bt}$ gradativamente vertente abaixo sem destruição de argilas, por ação mecânica do fluxo lateral de água, principalmente por mudança das condições hidrológicas durante a evolução da vertente.

b) Transformação do Bw por perda de cimentante (óxido de ferro), posibilitando a migração de argilas e modificando gradativamente o Bw para Bt vertente abaixo.

c) Degradação do Bw por destruição de argilas e surgimento do gradiente textural tendo como consequência a formação do Bt.

d) Evolução e exposição de material pouco intemperizado para a formação de solos com Bt em clima úmido com estação seca definida.

e) Combinação das hipóteses acima.

\subsection{7 - Linhas de pedra ("Stones lines") e descontinuidades litológicas}

Linhas de pedra, "stones-lines" ou cascalheiros são horizontes paralelos ou não à superficie do terreno, formados por fragmentos grosseiros de materiais resistentes ao intemperismo como quartzos e quartzitos, litorrelíquias, fragmentos de rocha e/ou de laterita, situados entre o horizonte que não os contém ou onde ocorrem de uma forma esparsa (adaptado de Lucas et al., 1990, citado por Vidal Torrado, 1994). Nos ambientes 
tropicais úmidos predominam seixos de quartzo, por serem mais resistentes ao intemperismo químico (Bigarella et al., 1994).

Em muitos casos, o material do horizonte $\mathrm{A}$ e dos demais horizontes que se sucedem em profundidade apresentam atributos químicos e mineralógicos similares aos do saprolito, apesar de sua estrutura muito contrastante a nível microscópico.O solo e o saprolito são comumente separados por linhas de pedras formadas por seixos de rochas resistentes (Schaefer, 1996). No presente estudo a linha de pedras é constituída de gnaisse ferruginizado.

Estas linhas de pedra são comuns no Brasil e sua gênese é controversa. A hipótese mais aceita é sua origem alóctone (Bigarella \& Mousinho, 1965a; Ab'Saber, 1966; Ranzani et al., 1972; Lepsch, 1977; Lecomte, 1988). Na região destes estudos, Camargo et al. (1962) constataram a presença de seixos de quartzo e quartzito no material argiloso que cobre as formações geológicas, distribuído desuniformemente em profundidade; atribuindo ao mesmo origem alóctone. Radambrasil (1983), observaram a oeste de Alfenas (MG), linhas de pedras constituídas por fragmentos de quartzo pouco trabalhados, com 5 a $7 \mathrm{~cm}$ de diâmetro, que separam o manto de alteração dos colúvios; podendo sua formação ser inferida como de natureza alóctone.

A origem alóctone da linha de pedras pode estar relacionada a descontinuidades litológicas. Muitos pesquisadores ( Chapman \& Horn, 1968; Sudon \& Arnaud, 1971; Dress \& Wilding, 1973; Rabenhorst \& Wilding, 1986; Luz et al., 1992; Cooper,1996) utilizaram minerais estáveis ou elementos pouco móveis como quartzo, zircônio e titânio para estabelecer a uniformidade de regolitos em profundidade. Este método foi proposto por Marshal (1940), que se baseou em elementos químicos que ocorrem em minerais resistentes ao intemperismo, considerando-os também resistentes e pouco móveis. Os teores destes elementos e as relações entre eles proporcionam um meio de estabelecer a uniformidade original do material pedológico ( Luz et al., 1992).

Dress \& Wilding (1973), estudando solos de sedimentos dos tipos loess e loam, propuzeram diferenças na relação $\mathrm{Ti} / \mathrm{Zr}$ entre 22 e $56 \%$, para estabelecer descontinuidades litológicas. As diferenças menores são exigidas para processos de deposição que melhor selecionam materiais como os ventos e os maiores gradientes são 
exigidos para processos de deposição que pouco selecionam materiais, como os deslizamentos. Luz et al. (1992) e Cooper (1996) utilizaram esta relação em regolitos no ambiente tropical e obtiveram resultados satisfatórios.

Origem biológica, sendo a "stone-line" formada por remonte vertical feito pela fauna do solo é a hipótese aventada por Cailleux \& Triticart (1959); Dijkerman \& Miedema (1988) e Eschenbrenner (1996).

Miklós (1992) considerando a autoctonia crescente de montante para jusante dos materiais acima da linha de pedras e o remonte vertical dos materiais profundos ( por formigas ou cupins ), atribuiu a origem atual de uma linha de pedras em Botucatu (SP) a ação da fauna.

Macfarlane e Pollard (1989), Vidal Torrado (1989) e Lichte (1990 e 1991) trabalharam com a hipótese de linhas de pedra de origem residual, formadas por alteração de rochas do embasamento cristalino com veios de quartzo.

Faniram \& Jeje (1983) abordaram a origem da linha de pedras segundo três conceitos distintos. O primeiro deles, o conceito do estado de equilíbrio, procura demonstrar que as linhas de pedras estão sendo formadas por processos geomorfológicos e pedológicos conteporâneos a partir de rochas com veios de quartzo que vão sendo intemperizadas e veios vão sendo incorporados dentro da massa em reptação e redistribuidos como um horizonte no topo do saprolito sedentário. O conceito do intemperismo residual procura explicar as linhas de pedras como produtos residuais do intemperismo químico que progride para o interior do maciço rochoso. Os produtos de alteração seriam removidos em solução por drenagem freática, enquanto que os minerais resistentes ao intemperismo se acumulariam junto com o ferro mobilizado, que oxidaria e endureceria quando exposto à superficie. $\mathrm{O}$ último deles, o conceito da perturbação faunística, é baseado na remoção seletiva das particulas finas do solo da subsuperficie para a superficie, pelas térmitas, formigas e vermes. Esta atividade contribuiria para a formação de um horizonte distinto constituido por fenoclastos de quartzo e em menor escala por concreções de ferro formadas "in situ".

Bigarella et al. (1994) expõe que seria um erro afirmar que uma única teoria devesse ser aplicada na elucidação da gênese de todos os pavimentos rúdaceos existentes 
nos trópicos. Para este autor o conceito de intemperismo residual é mais aplicavel quando ocorre um contato abrupto entre a linha de pedras e o embasamento litológico ou uma camada de natureza coluvial. Quando existe uma quantidade considerável de matriz entre os fenoclastos, é mais aplicável a teoria da perturbação faunistica.

Para Lichte (1990 e 1991) as linhas de pedras não devem ser olhadas como um aspecto simples e isolado, mas sim como inseridas no ambiente e conectadas com o relevo, como parte de um complexo sistema de evolução da paisagem, pois as diferentes fases do desenvolvimento das linhas de pedras podem ser descritas como os diferentes passos no desenvolvimento do relevo atual. Este mesmo autor, estudando as linhas de pedra de uma área afim e próxima da região destes estudos por meio de datações por caborno-14 e análises de termoluminescência, concluiu que as mesmas foram formadas a cerca de 20.000 anos por morfogênese mecânica, durante uma mudança de clima úmido para semi-árido e tendo como fonte de material veios de quartzo em rochas do embasamento cristalino.

Bigarella et al. (1994) cita a ocorrência de artefatos pré-históricos em linhas de pedras, datados como tendo idade entre 2.000 e 10.000 anos. A presença destes artefatos indica que o ambiente, embora semi-árido, não era tão seco ou árido de forma a impossibilitar a presença do homem na área de sua formação.

Vidal Torrado (1994), expõe que estes cascalheiros também podem ser herdados por herança litoestratigráfica local, ou seja, de rochas sedimentares que os contenham previamente. Para este autor, as diferentes interpretações dadas para a gênese das "stones-lines" sugerem que é muito provável que as mesmas tenham origem distinta e, em alguns casos, a combinação das hipóteses anteriormente mencionadas possa dar melhor resposta ao problema.

Stoking (1978) argumenta que: "uma resposta para as muitas hipóteses formuladas sobre a gênese das linhas de pedras é que talvez estas padeçam de equifinalidade geomorfológica, ou seja, nenhuma hípotese simples pode prover uma explicação universal e linhas de pedras similares podem ser formadas como resultado de diferentes combinações de circunstâncias ambientais". 


\section{3 - MATERIAL E MÉTODOS}

\section{1 -Caracterização do meio físico}

\subsection{1- Localização}

A área considerada localiza-se nos municípios de Machado e Alfenas, (Sul do Estado de Minas Gerais), entre os paralelos $21^{\circ} 37^{\prime}$ e $21^{\circ} 41^{\prime}$ e os meridianos $45^{\circ} 51^{\prime}$ e $45^{\circ} 57^{\prime}$ WGR. É limitada a leste pelo rio Machado, ao norte pela linha de topos das colinas suavizadas, ao sul pela Serra dos Alemães e ao oeste pelo Ribeirão Caiana (figura 3). Ocupa 5.750 ha.

\subsection{2- Relevo e solos}

Faz parte do Planalto de Varginha, onde o relevo é constituído de colinas com vertentes convexas e topos convexados ou tabulares, intercalados por alvéolos, com incisões de drenagem entre 44 e $92 \mathrm{~m}$ e declives entre 5 e $24^{\circ}$, entremeados a colinas com vertentes longas de declives menores que $8^{\circ}$ e incisões de drenagem entre 23 e $42 \mathrm{~m}$ (Radambrasil, 1983). Este relevo está representado na bloco diagrama da figura 4.

Para Camargo et al. (1962) as partes mais declivosas da paisagem são denominadas superficie dissecada de topografia montanhosa e as partes mais aplainadas de superficie rebaixada de patamares colinosos; que podem corresponder respectivamente à Superficie Sul Americana e Superficie Velhas (King ,1956). 


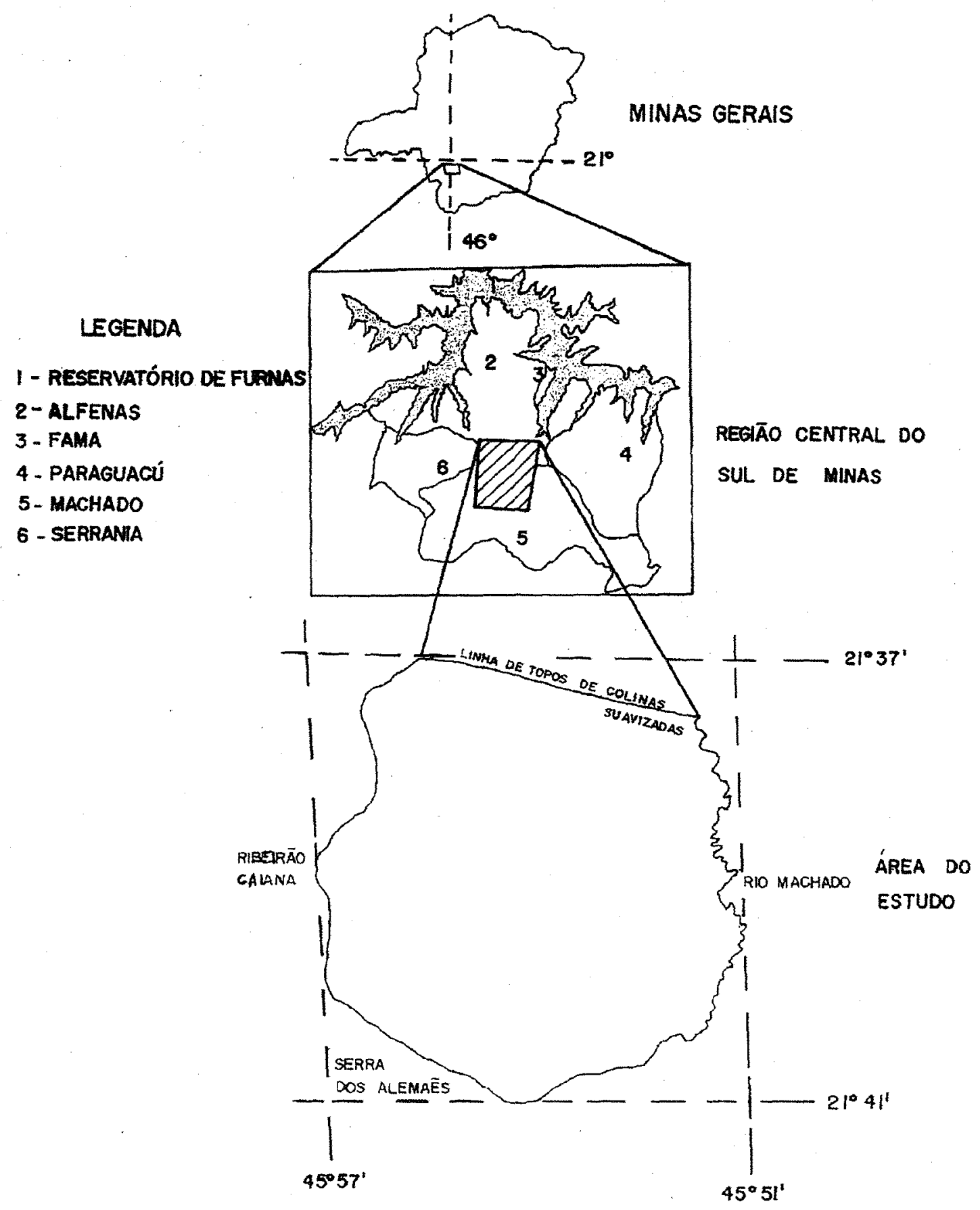

Figura 3. Localização da área dos estudos 


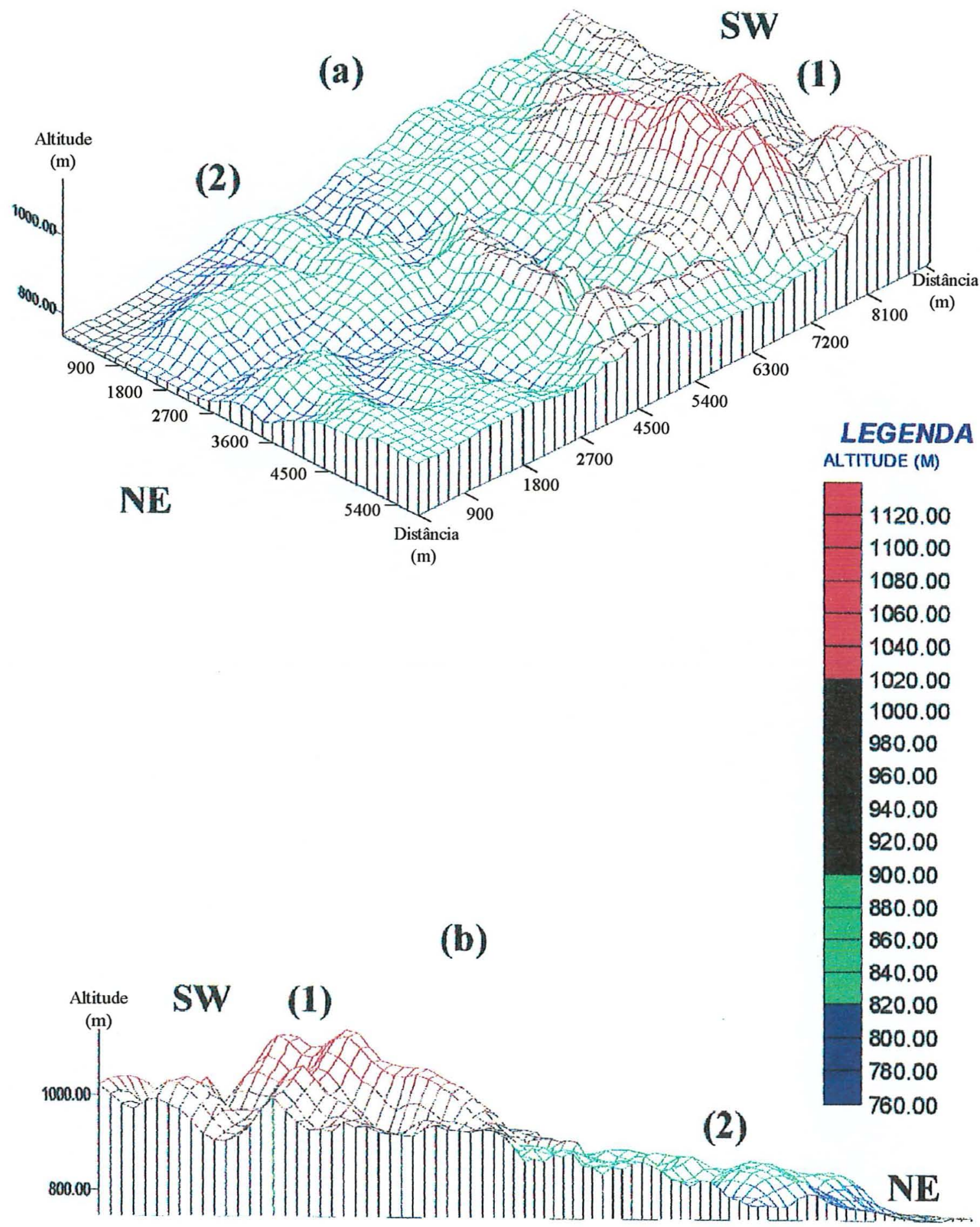

Figura 4. Bloco diagrama hipsométrico da área estudada na escala original de 1:50.000. (a) Vista frontal. (b) Vista lateral. (1) Área representada pelo Sistema Morfopedológico I. (2) Área representada pelo Sistema Morfopedológico II. 
No sistema morfopedológico aplainado, denominado SMII (figura 6) e que corresponde a superficie rebaixada, predominam latossolos em todas as posições da vertente, mesmo em locais de elevada declividade, podendo ocorrer associados a bolders de rochas. No cume do sistema morfopedológico mais elevado, denominado SMI (figura 5) e que corresponde a superficie dissecada, ocorrem solos litólicos, transicionando encosta abaixo pela face sul com podzólicos e pela face norte com latossolos, húmicos ou não, e podzólicos. Nas margens dos rios são encontrados solos aluviais e nas várzeas solos hidromórficos.

\subsection{3- Vegetação e clima}

A vegetação natural dominante é composta, segundo Golfari (1975), de floresta tropical perenefólia ou subperenifólia, com ocorrência de cerrado. Atualmente este tipo de vegetação é denominado floresta estacional semidecidual. Segundo observações de Campos \& Landgraf (1990), atualmente a região conta com apenas $6 \%$ de cobertura florestal natural.

De acordo com a classificação de Koppen, o clima da região enquadra-se no tipo Cwb (Camargo et al., 1962), ou seja, subtropical moderado úmido; com a temperatura média do mês mais frio oscilando entre 13 e $16^{\circ} \mathrm{C}$ e a do mês mais quente entre 21 e $23^{\circ} \mathrm{C}$. O inverno caracteriza-se por 2 a 4 meses secos, com um déficit hídrico entre $10 \mathrm{e}$ $30 \mathrm{~mm}$ anuais. As precipitações médias oscilam entre 1400 e $1500 \mathrm{~mm}$ anuais, sendo seu regime de distribuição periódico, predominando nos meses mais quentes do ano. Os regimes hídrico e térmico do solo são, respectivamente, údico e isotérmico, (Resende et al., 1988).

\subsection{4-Geologia}

O embasamento rochoso é constituído por rochas dos Complexos Amparo, e Guaxupé ( Fiori, 1979; Radambrasil, 1983; Minas Gerais, 1983; Artur, 1988). Estas rochas apresentam atitude de foliação de direção dominante WNW-ESE e ângulo de 


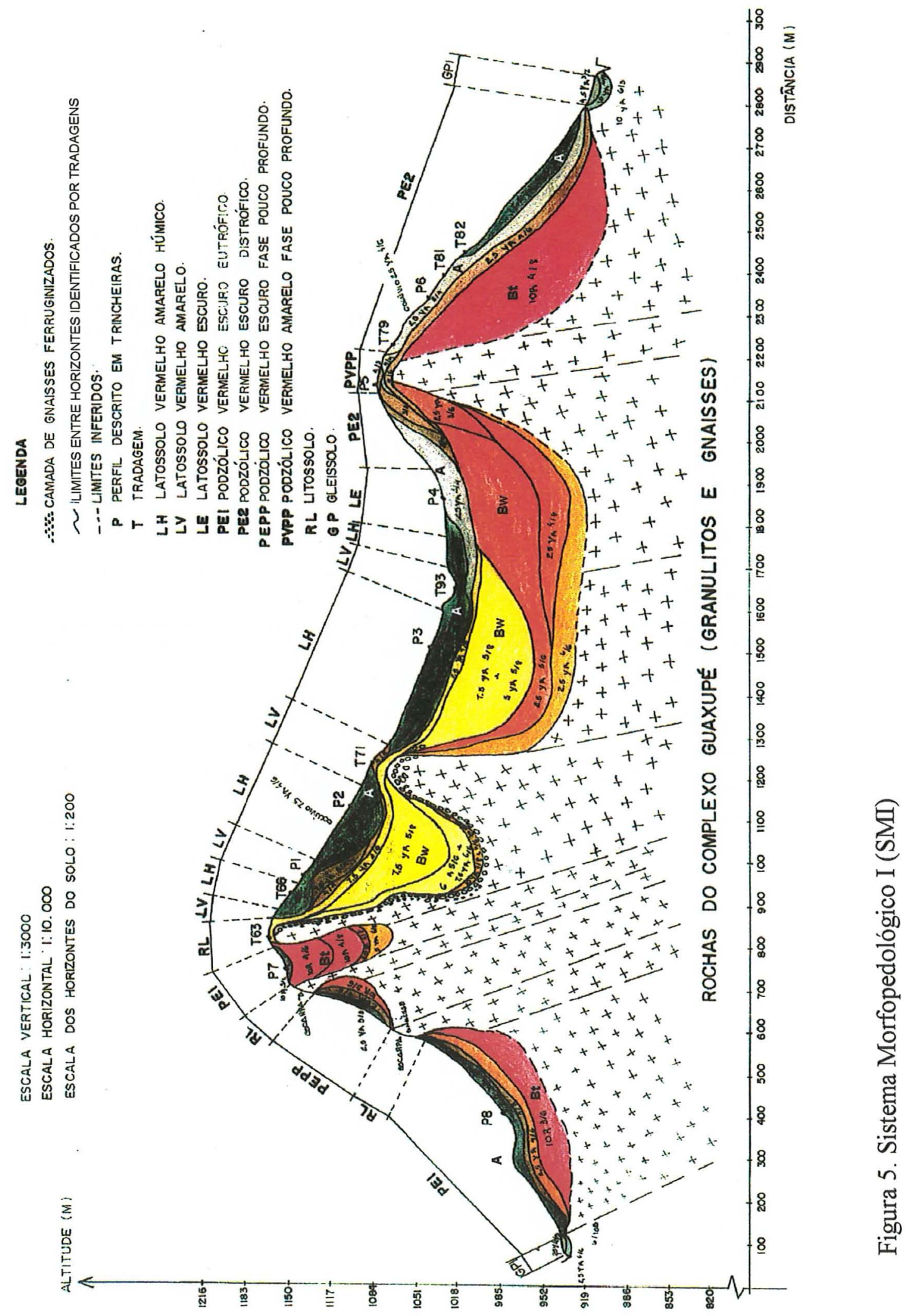



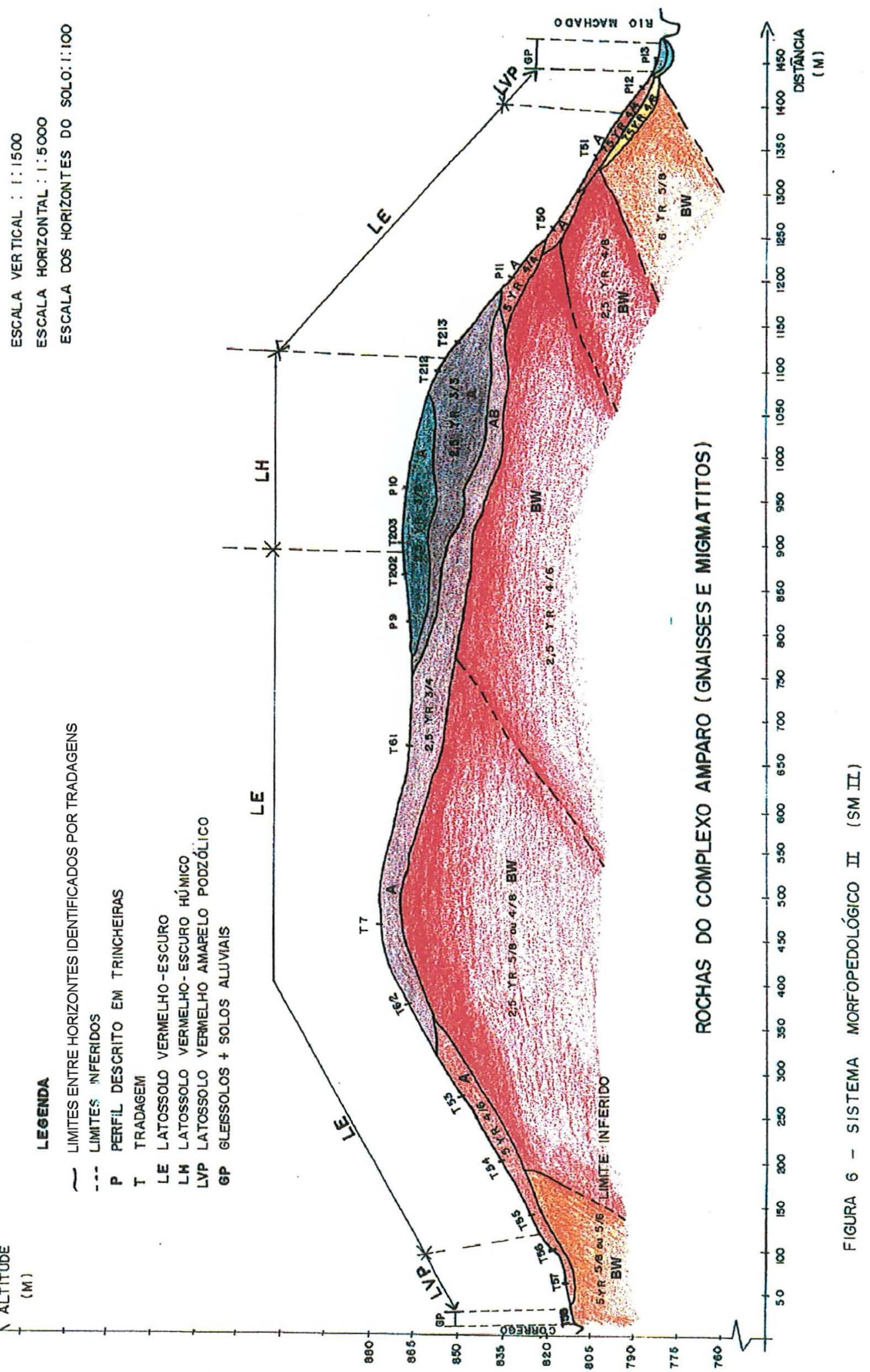
mergulho entre 20 e $50^{\circ}$, predominantemente SSW, mas também são encontrados ângulos de mergulho NNE. As cristas apresentam-se rotacionadas para oeste, ( Fiori, 1979).

A estrutura regional do Sul de Minas é formada por antigos embasamentos arqueanos, que foram remobilizados uma vez durante o Proterozóico (ciclo Transamazônico) e outra vez no Cambriano (ciclo Brasiliano), Saadi (1991).

A região deste estudo localiza-se em um grande bloco triangular, com o vértice voltado para leste, denominado Cunha de Guaxupé, por Hasui et al. (1990a). Gnaisses e migmatitos do Complexo Amparo encaixam granulitos do Complexo Guaxupé e compõe a geologia regional. Está delimitado ao norte pela zona transcorrente Cássia-Barbacena e ao Sul pela Zona Transcorrente Mogi-Guaçu-Carandaí (figura 7). Estas zonas compreendem um feixe de falhas, fraturas e suturas perfeitamente visíveis em fotografias aéreas e imagens de satélite (figura 8). Foram caracterizadas por vários autores (Wernich et al., 1981; Hasui et al., 1987 e 1990a; Hasui, 1990; Mioto, 1990; e Saadi, 1990 e 1991) como áreas instáveis desde o Pré-Cambiano até o Terciário.

A W-SW da Cunha de Guaxupé o vulcanismo, formou no final do Cretáceo e início do Terciário, uma imensa Caldeira $\left(800 \mathrm{~km}^{2}\right)$, denominada de Complexo Poços de Caldas, com rochas ultrabásicas. Esta caldeira foi originada pelo abatimento do edificio vulcânico, causado pela saída de magma e refluxo do magma pelo escape de gases. Como conseqüência deste fenômeno, zonas de fraturamento e abatimentos formaram-se ao redor do edificio vulcânico, resultando em um basculamento regional de blocos litológicos, levado a cabo preferencialmente no contato entre as duas litologias e evidenciado por cristas de orientação circular (diques anelares), como as vistas na figura 9, baseada em imagem satélite Landsat banda 3 na escala de 1:100.000

\subsection{5-Uso da terra}

A ocupação da área iniciou-se no despertar do século XVIII, quando os bandeirantes, de passagem rumo às minas de ouro e de pedras preciosas dos Campos das Vertentes e da região de Vila Rica, fundaram pequenos núcleos urbanos que se 


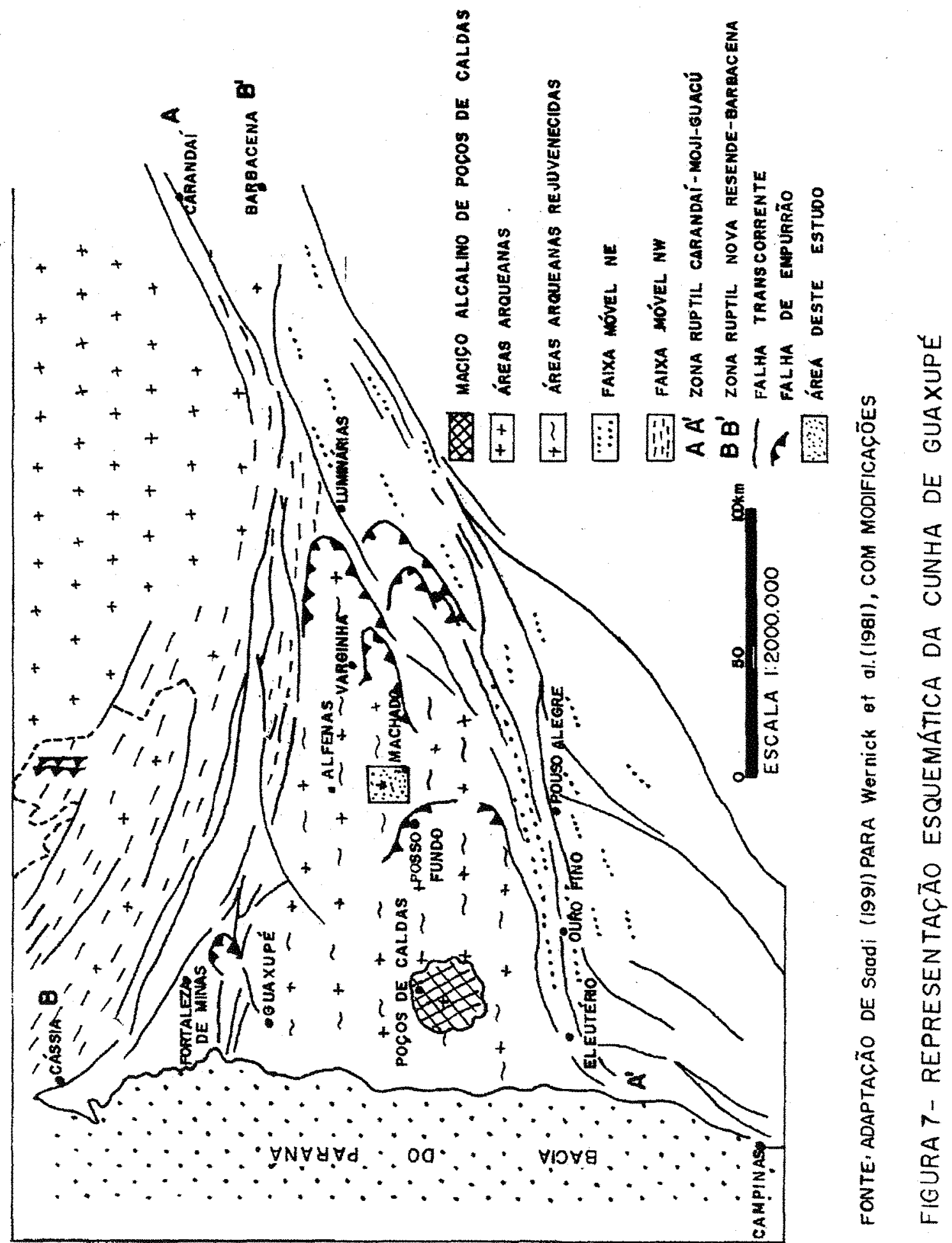




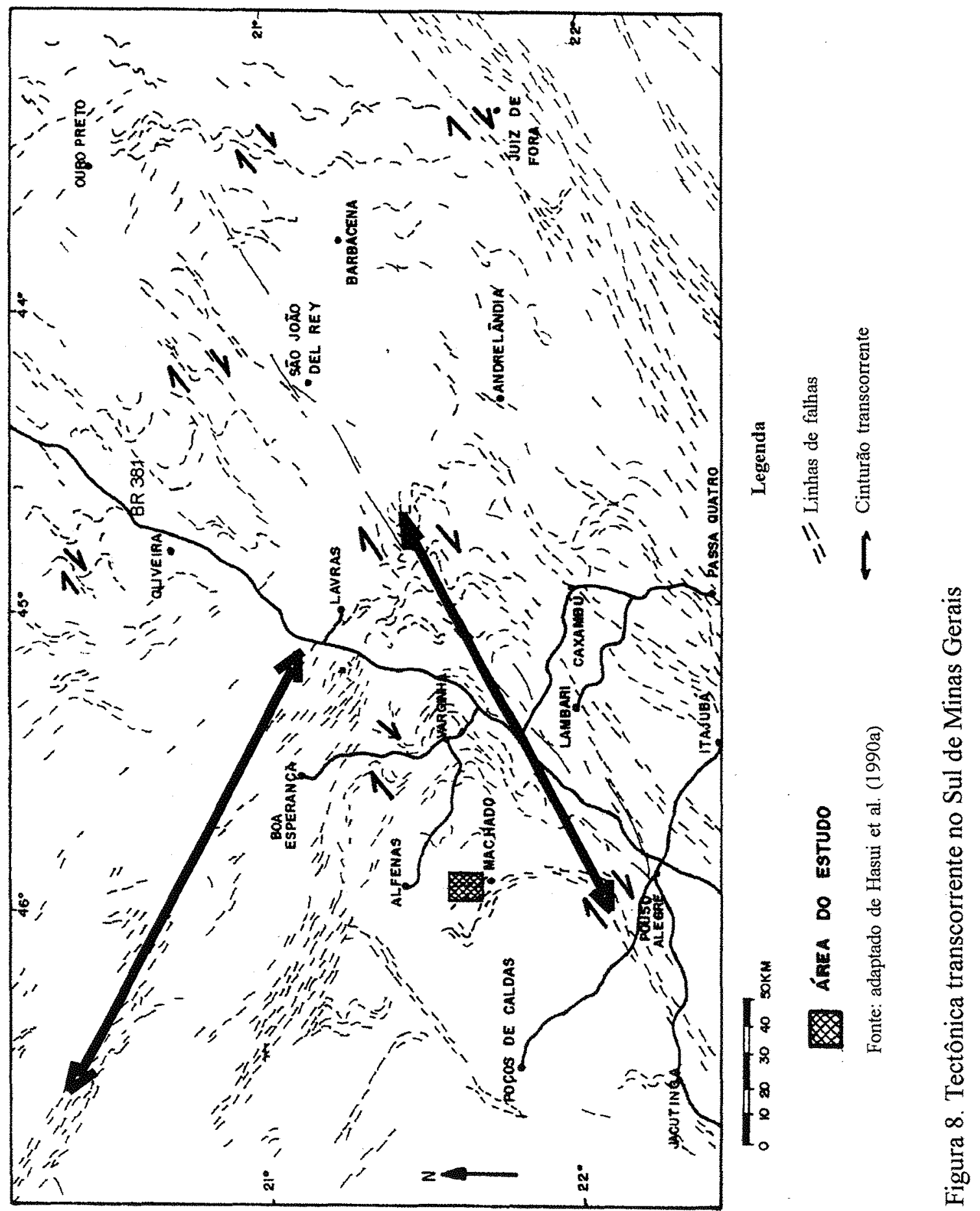




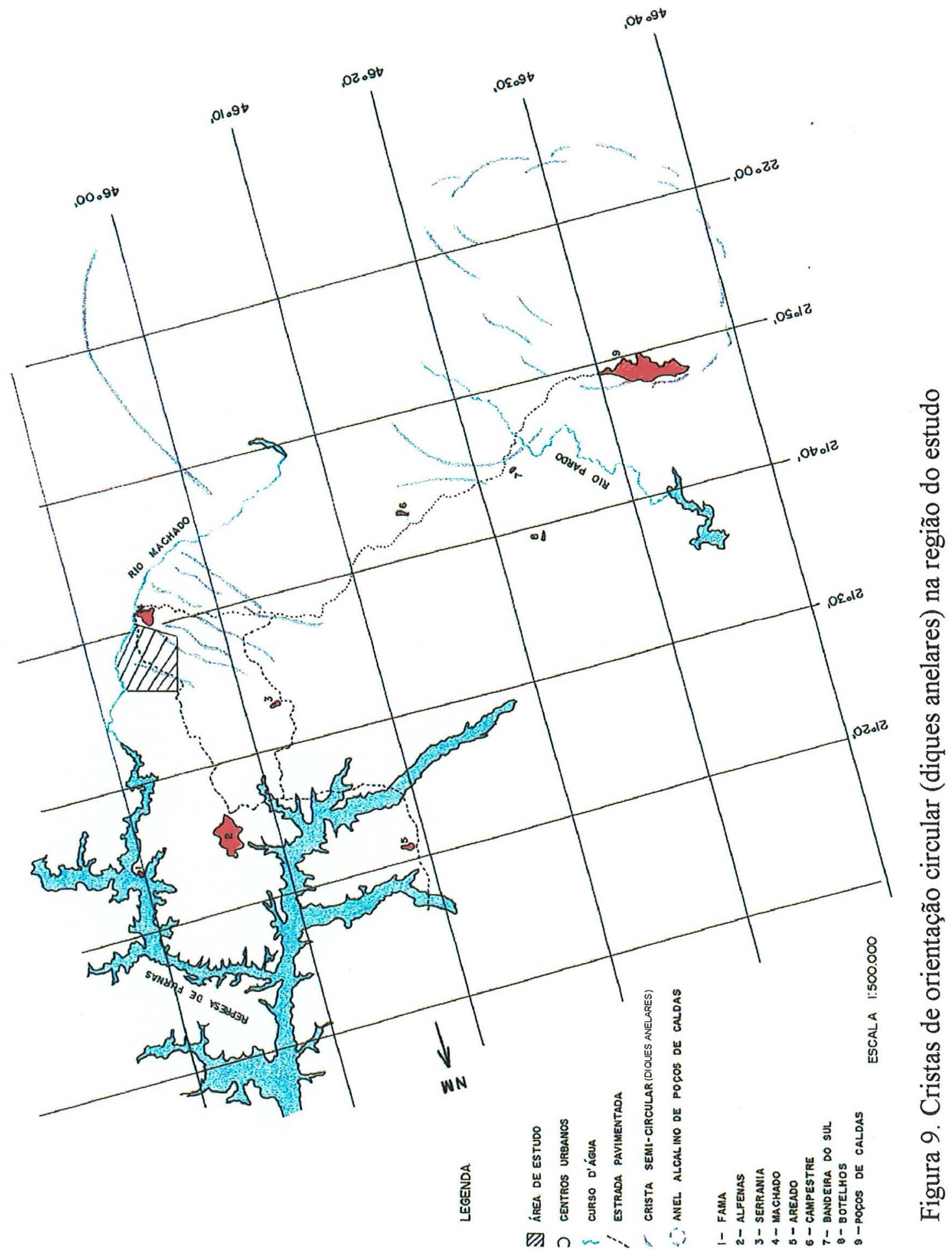


mantiveram por muitos anos através da pecuária. Com o advento da industrialização de São Paulo, a região foi desmatada para fornecer madeira e as pastagens passaram a dominar a paisagem. Nas décadas de 50 e 60 a política de incentivos promoveu uma grande expansão da cultura do café.

Atualmente as terras do reverso de SMI estão sendo utilizadas para a produção de café e forragens (figura 10). Apenas na meia encosta do front é que ocorre uma floresta estacional semi-decidual, que sofreu desmate seletivo. Nas terras do SMII estão implantadas pastagens, lavouras de café e culturas anuais (figura 11).

\section{2-Mapeamento preliminar dos solos}

Após o exame dos levantamentos de solos de baixa intensidade da região encontrados na literatura (Radambrasil, 1983; Camargo et al., 1962) toda área foi percorrida para, através de tradagens e observações em cortes de estrada, fazer um reconhecimento dos solos, observando-se a morfologia dos mesmos.

\section{3-Mapeamento geomorfológico e identificação de feições tectônicas}

Após visitas de campo a área dos estudos, fotointerpretação de fotografias aéreas nas escalas de 1:65.000 (GERCA, 1965) e de 1:30.000 (CEMIG, 1984), interpretação de imagens do satélite Landsat banda 3 (preto e branco) e bandas 3 e 4 (composição colorida) e apoio de ortofotocartas na escala de 1:10.000 (CEMIG, 1984); foi elaborado, sob a orientação do Geógrafo Allaouá Saadi ( Professor Titular do IGC/UFMG) o mapa geomorfológico do local, destacando topos convexos, soleiras, escarpas, deslizamentos e outros aspectos da paisagem.

Nos trabalhos de campo, foram feitas observações detalhadas das formas do relevo, de cortes de estradas e de afloramentos de rocha da área, procurando-se identificar feições geomorfológicas, litológicas e pedológicas que pudessem indicar evidências de falhas e de movimentos atribuídos à tectônica ressugente. 


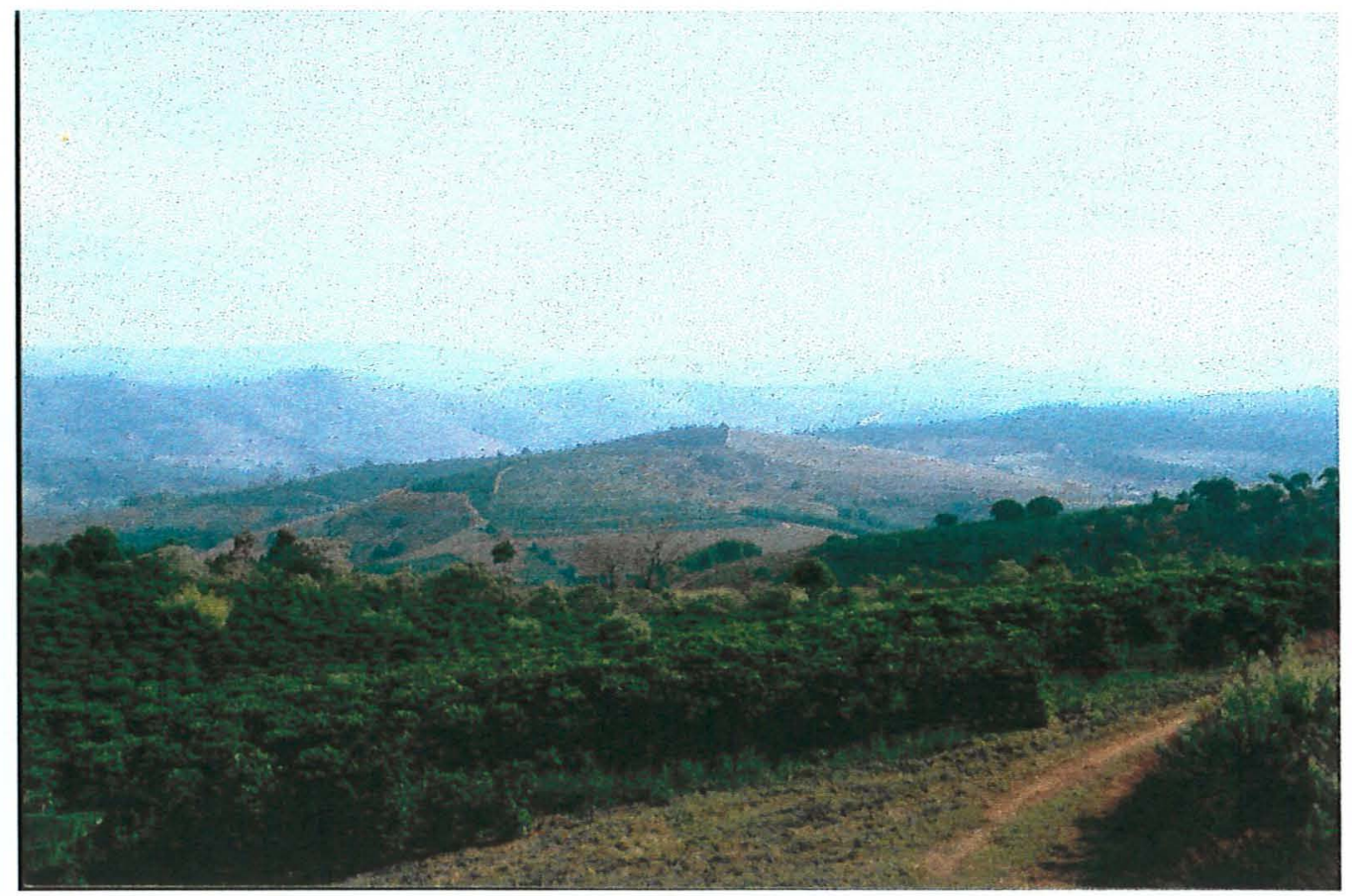

Figura 10. Vista parcial do SMI. Cafezais e pastagens dominam a paisagem

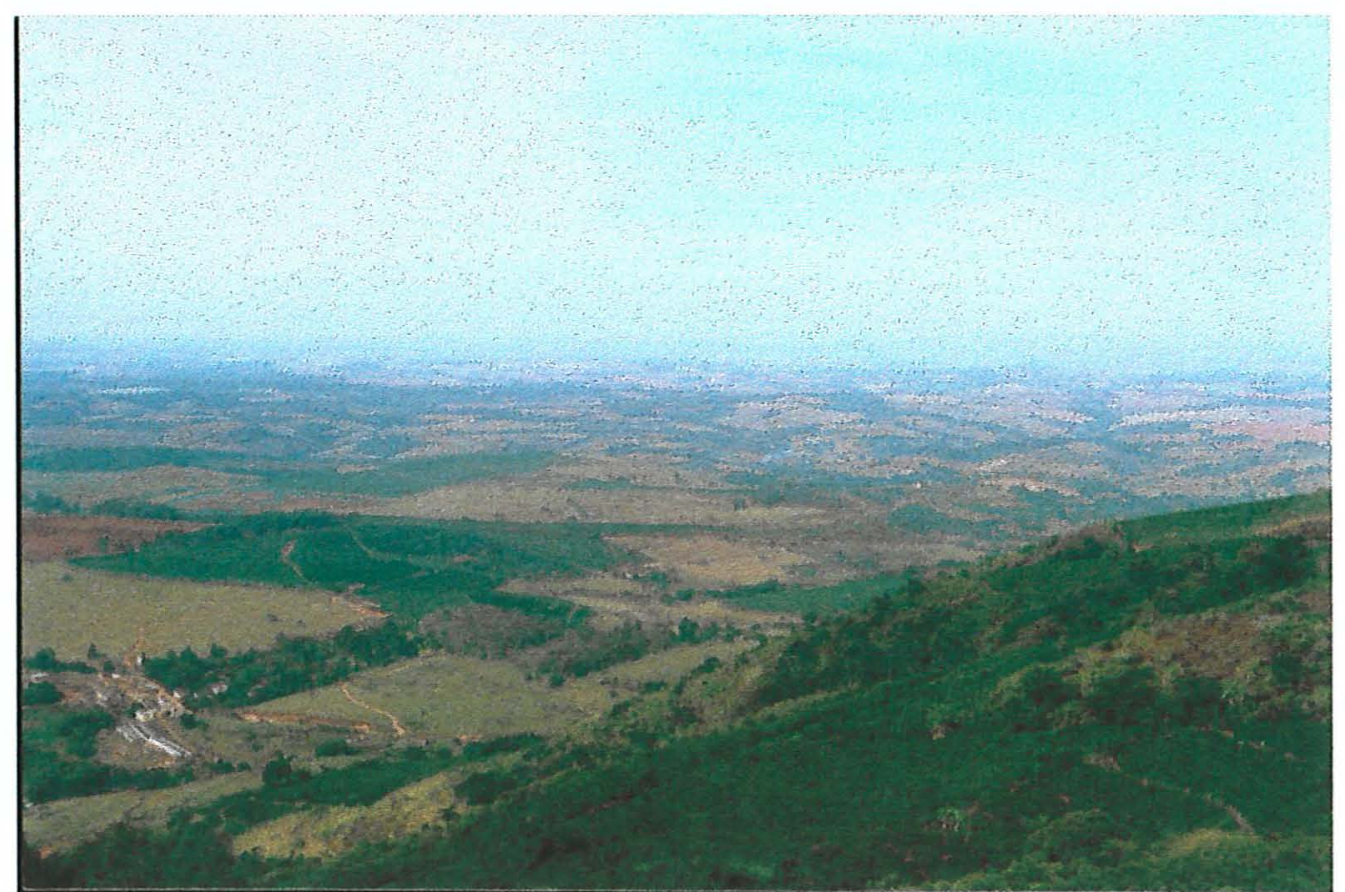

Figura 11. SMII observado a partir de SMI. Äreas utilizadas com cafezais, pastagens e culturas anuais. Detalhe: escarpa na parte central da imagem. 


\section{4-Mapeamento geológico}

Fiori (1979), executou o Mapeamento Geológico da Porção Sul do Estado de Minas Gerais na escala de 1:100.000. Este trabalho foi utilizado como base para detalhamento de informações a respeito da geologia da área em apreço, feita através de visitas a afloramentos rochosos, barrancos de estradas, pedreiras e leito de rios.

Posteriormente foi elaborado para a área do estudo um mapa com feições geológicas na escala de 1:30.000 por fotointerpretação de aerofotos de mesma escala.

\section{5-Amostragem dos solos}

Após o reconhecimento dos tipos de solos e da geologia do local, foram escolhidos dois sistemas morfopedológicos mais representativos de uma ampla região do Centro-Sul de Minas para caracterização dos solos e das feições superficiais, onde foram estudados os processos pedogenéticos e a dinâmica das paisagens. Nestes sistemas foram abertas 15 trincheiras (10 trincheiras em SMI e 5 em SMII), para descrição morfológica dos perfis, de acordo com Lemos \& Santos (1984), e coleta de amostras deformadas de cada horizonte para análises fisicas e químicas em laboratórios. Foram coletadas também 40 amostras indeformadas para análise micromorfológica. Com o amostrador de Uhland foram coletadas 54 amostras indeformadas para avaliação da densidade do solo de acordo com Embrapa (1979). Em cortes de estrada, barrancos e pedreiras foram examinados os contatos solo/rocha e as transições entre os horizontes B e C.

\section{6-Morfologia dos solos ( Pedografia )}

A morfologia dos solos foi descrita em três escalas diferentes, ou seja, no campo, em amostras indeformadas investigadas através de lupa estereoscópica Zeiss, com aumento de 20 e 40 vezes e através de lâminas delgadas (micromorfologia), cujas imagens foram ampliadas e fotografadas em fotomicroscópio Zeiss, de 28 a 208 vezes. Este procedimento foi adotado nos dois Sistemas Morfológicos (SMI e SMII), cuja 
localização e direção estão apresentadas nos mapas geomorfológicos (figura 21), e de solos (figura 30).

Através de tradagens e de observações de cortes de estradas, um estudo bidimensional da distribuição lateral dos horizontes e sub-horizontes dos solos foi realizado, de acordo com metodologia proposta por Boulet et al. (1987). As figuras 5 e 6 mostram a sequência vertical e a distribuição lateral, por cor, dos horizontes, nos 2 sistemas morfopedológicos estudados. Para a confecção destas figuras foram realizadas 118 tradagens em SMI e 72 tradagens em SMI, a até $2 \mathrm{~m}$ de profundidade.

Em 10 perfis descritos, foram coletadas 41 amostras indeformadas e orientadas, utilizadas primeiramente para investigação com auxilio da lupa (aumentos de 20 e 40x). Posteriormente as mesmas foram impregnadas com resina de poliester para serem elaboradas seções delgadas de acordo com Castro, (1985). A análise micromorfológica foi feita em microscópio petrográfico Zeiss, de acordo com os critérios estabelecidos por Brewer (1976), com adaptação para a descrição da trama do solo segundo Lima et al. (1985). A obtenção de fotomicrografias em fotomicroscópio Zeiss, foi realizada na Escola de Farmácia e Odontologia de Alfenas (EFOA), em Alfenas-MG.

\section{7-Identificação de solos originados a partir de diferentes materiais e de descontinuidades litológicas em profundidade.}

Em 05 trincheiras (P1, P2, P3, P4 e P7) foram feitas tradagens profundas até atingir o saprolito da rocha subjacente. Nas amostras coletadas, bem como em outras amostras dos horizontes A e B sobrejacentes ao saprolito, foi feita análise estatística das distribuições das areias, objetivando-se detectar possíveis descontinuidades de materiais de origem. Para tanto, a fração areia destas amostras foi fracionada em cinco classes granulométricas, que correspondem às classes areia muito grossa, areia grossa, areia média, areia fina e areia muito fina da escala americana de divisão da fração terra fina. $\mathrm{Na}$

escala Phi, estas classes são representadas respectivamente pelos intervalos de -1 a 0,0 a 1,1 a 2,2 a 3 e 3 a 4, 33. Utilizando-se o programa PHI para microcomputador (Jong van Lier \& Vidal Torrado, 1992) os valores obtidos nas pesagens das areias foram 
tratados estatisticamente pelos critérios de Folk e Ward e foram construídos os gráficos de distribuição (em escala de distribuição normal) e os histogramas de barras destas distribuições.

Concomitatantemente foi determinada a concentração de titânio, zircônio e ferro, através da tecnica de fluorecência de raios X por dispersão de energia, na seção de radioisótopos do Centro de Energia Nuclear na Agricultura (CENA/USP), em Piracicaba-SP, de acordo com a técnica preconizada por Espen et al. (1977) e Espen et al. (1991). Variações nos teores de Ti, Zr, e da relação $\mathrm{Ti} / \mathrm{Zr}$ têm sido usadas por vários pesquisadores (Drees \& Wilding, 1973; Luz et al. 1992; Cooper , 1996), para detectar descontinuidades litológicas.

\section{8-Análise das amostras de terra}

As análises granulométricas e químicas de rotina $(\mathrm{pH}$, carbono orgânico, fósforo assimilável, elementos do complexo sortivo e acidez total) foram feitas nos laboratórios do Instituto de Ciências Agrárias da UNIFENAS, de acordo com a metodologia descrita por Vettori (1969) e Embrapa (1979).

\section{9-Datações por Carbono $\left(\mathrm{C}^{14}\right)$}

Em diferentes horizontes dos perfis P3 e P10 foram coletadas amostras de carvão. Estas amostras foram lavadas em água destilada para a retirada de terra e outras impurezas. Em seguida foram encaminhadas para datações por $\mathrm{C}^{14}$, ao Centre for Isotope Research da Gronigen University (Holanda), através do convênio entre o Departamento de Edafologia y Química Agrícola da Universidade de Santiago de Compostela (Espanha) e do Departament of Soil Science and Geology da Agricultural University of Wageningem (Holanda). 


\subsection{0-Mineralogia da fração argila}

A composição mineralógica da fração argila foi determinada nos laboratórios do LSO-ESALQ/USP. Amostras selecionadas do horizonte B dos solos foram preparadas e tratadas em consonância com a metodologia proposta por Jackson (1969). A fração argila $(<0,002 \mathrm{~mm}$ de diâmetro) foi separada por sifonação, após tratamento para eliminação da matéria orgânica e dos óxidos de ferro. Subamostras foram saturadas com $\mathrm{K}^{+}$ou $\mathrm{Mg}^{++}$para irradiação com raios $\mathrm{X}$ através do difratômetro Rigaku, com tubo de cobre e filtro de níquel no intervalo $2 \theta$ de 3 a $32^{\circ} \mathrm{C}$. As subamostras saturadas com $\mathrm{K}^{+}$ foram irradiadas na temperatura ambiente, após aquecimento a 350 e $550^{\circ} \mathrm{C}$. As saturadas com $\mathrm{Mg}^{++}$foram irradiadas na temperatura ambiente em duas etapas, antes e após a solvatação com etileno-glicol, respectivamente.

Os resultados obtidos foram codificados em uma escala, a partir de análise comparativa entre os difratogramas. As amostras que apresentavam maior intensidade de picos de um mineral recebiam o número máximo de referências e as outras amostras eram classificadas proporcionalmente a este resultado.

\subsection{1 - Mapeamento Semi-detalhado de Solos}

De posse dos resultados analíticos das amostras de terra, da descrição morfológica dos perfis e tradagens e com apoio de trabalhos de mapeamento de solos executados anteriormente na área dos estudos, foi elaborado um mapa semi-detalhado de solos, através de fotointerpretação pedológica de aerofotos da CEMIG (1984), na escala de 1:30.000 e de aferições de campo, tendo com base cartográfica ortofotocartas restituídas na escala de 1:10.000( CEMIG, 1984). 


\section{4- RESULTADOS E DISCUSSÃO}

\subsection{Quadro estrutural e geotectônico regional}

O quadro estrutural é marcado por intensa atividade tectônica e vulcanismo, pelo menos até o Terciário Inferior. Considerando-se um período de quiescência tectônica, a partir do Terciário Médio, as bases para se chegar às feições geomorfológicas já teriam sido lançadas, resultando, pela ação da erosão, no aparecimento das superfícies de aplanaimento "Sul Americana" e "Velhas" descritas por King (1956) . Os fenômenos que adicionariam energia ao sistema, de maneira a construir as formas atuais da paisagem e aspectos da cobertura pedológica, seriam predominantemente climáticos, ativando a dissecação do relevo pelo recuo de encostas.

Porém, existem evidências que demonstram a participação da tectônica neocenozóica no afeiçoamento do relevo, aportando energia para reativação de fenômenos como os movimentos de massa e a erosão (tanto mecânica como geoquímica) devido a mudança de níveis de base. A aceleração do soerguimento de grandes maciços no final do Terciário como a Serra da Mantiqueira (Saadi, 1991) provocou a reativação de falhas e novo basculamento de blocos. A tectônica, juntamente com as mudanças climáticas, volta a assumir papel preponderante na dinâmica de encostas.

Uma destas evidências é a ocorrência de eventos sísmicos na região em pauta. A Estação Sismológica de Brasilia registrou 6 abalos sísmicos significativos na década de 90. Mioto (1990), insere a região na Zona Sismogênica de Passos (Figura 12). Este mesmo autor coloca que eventos sísmicos refletem uma tectônica residual, com acomodação dos blocos movidos no Terciário. Saadi (1991), também coloca a 


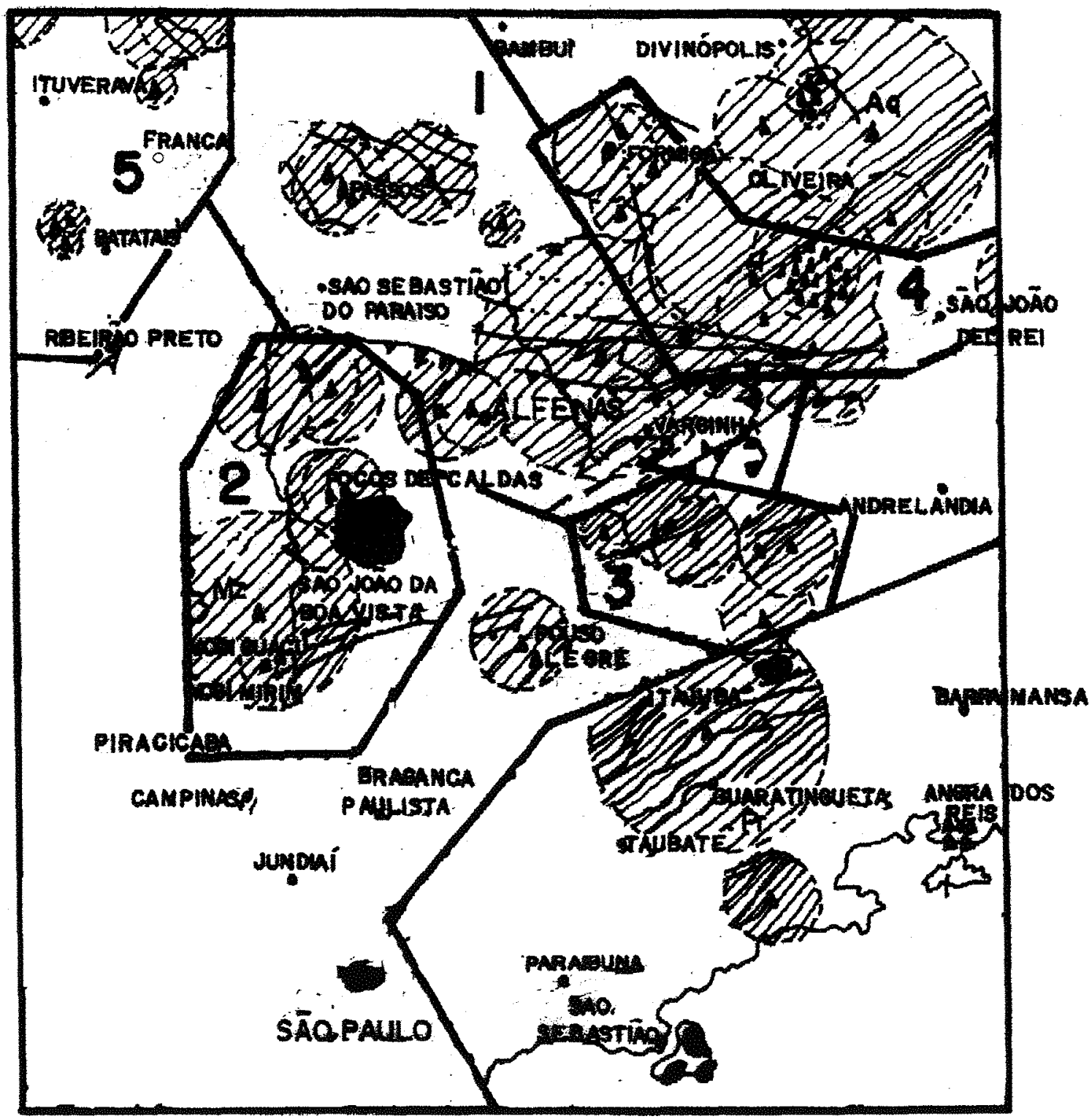

\section{ELEMENTOS SISMOLÓGICOS}

4 - epicentro provável

- região de erro epicentral

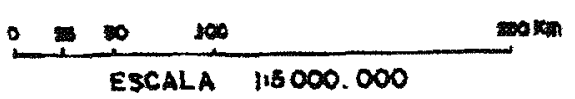

- limite de zona sismogénica

1. ZONA SISMOGẼNICA DE PASSOS

2. ZONA SISMOQẼNICA DE PINHAL

3. ZONA SISMO OËMICA DE CAXAMBU

Fonte: adaptado de Mioto et al. (1990)

4- ZONA SISMOGẼNICA DE BOM SUCESSO

5- ZONA SISMOGËNICA DO RIO GRANDE

Figura 12. Zonas sismogênicas do Sul de Minas Gerais 
sismicidade como uma ferramenta para a detecção ou confirmação de estruturas tectônicas atualmente ativas.

Outra evidência é a presença de uma sequência de falhas orientadas na direção SE-NW, no saprolito e no solum de um corte de estrada situado em zona de transição entre o Complexo Guaxupé e o Complexo Amparo (Figura 13). Registrou-se neste local uma superficie polida (espelho da falha) com estrias (Figura 14). No saprolito, a superficie lisa e as estrias ocorrem continuamente ao longo do plano de falha. No solum, esta estrutura ocorre de maneira mais dispersa e suas estrias são menos salientes. A presença destes fragmentos de espelhos de falhas nos falhamentos localizados no solum pode ser considerada uma evidência da ação da tectônica quaternária, pois a intensa ação da fauna do solo desde o Terciário já poderia ter provocado sua destruição. Os fragmentos polidos e estriados partem-se em forma de amêndoas, forma característica resultante da compressão causada por movimentos da crosta. Schaefer (1996), também encontrou espelhos de falha assim descritos em solos da Zona da Mata (MG). A análise micromorfológica de todas as laminas dos solos de SMI revelou a presença de poros fissurais orientados preferencialmente na mesma direção (Figuras 15 e 34).

Uma amostra indeformada foi coletada, impregnada, cortada e polida para a confecção de lâmina delgada. A descrição destas lâminas em microscópio petrográfico e as fotomicrografias revelam descontinuidades, empurrões, torções e deslocamentos dos minerais primários componentes do regolito, bem como adensamento do material localizado na falha em relação ao material adjacente. Uma estrutura denominada drag ( empurrão) é perfeitamente visível (Figura 16).

Observando-se os dados da Tabela 1, verifica-se similaridades entre o material coletado exatamente no local da falha e o material coletado ao lado da falha. As pequenas diferenças encontradas quanto a granulometria possivelmente se dão pela circulação mais rápida de soluções no local exato da falha. A Figura 17 mostra a distribuição das areias nestas duas amostras. Ambas são platicurticas, com elevado desvio padrão.

Os atributos químicos desta dois materiais também evidenciam a mesma natureza geológica do material de origem. A CTC (capacidade de troca de cátions) e a soma de bases são baixas. Os valores V\% (saturção de bases) e $\mathrm{m} \%$ (saturação de 
aluminio) mostram, respectivamente, baixos teores de bases trocáveis e consideráveis teores de alumínio trocável, evidenciando a pobreza química do material em relação a nutrientes disponíveis para as plantas.

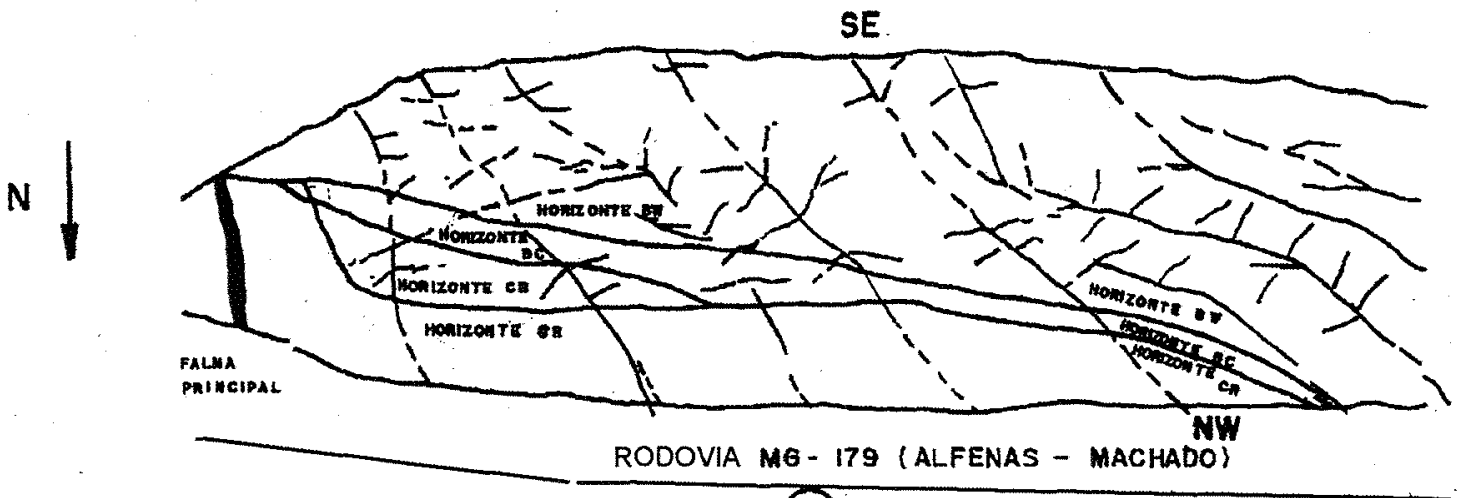

(A)

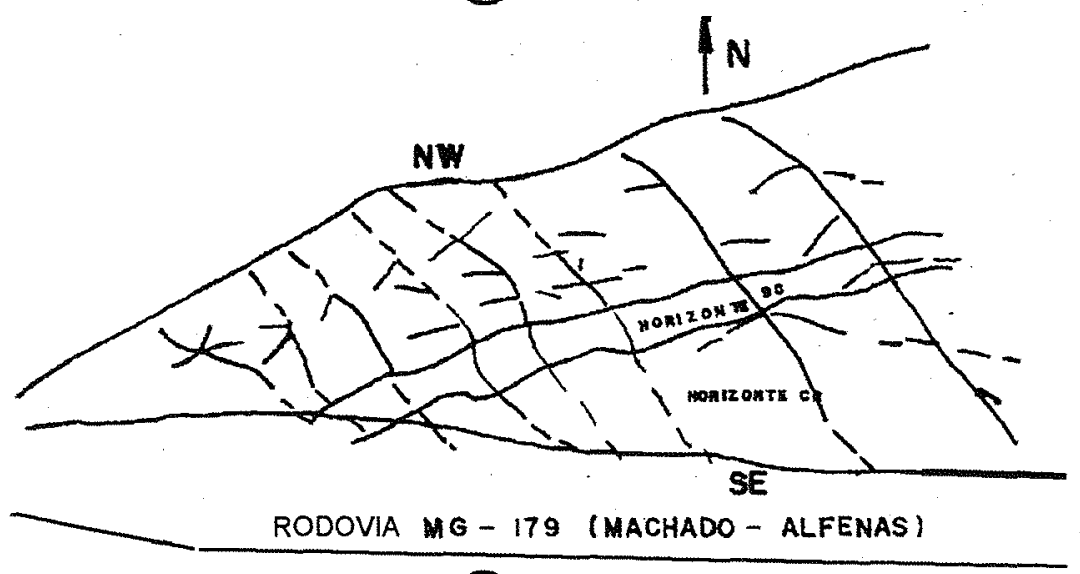

(B)

Escala de 1:450

Figura 13. Sequência de falhas observadas em um corte de estrada da MG -179. 


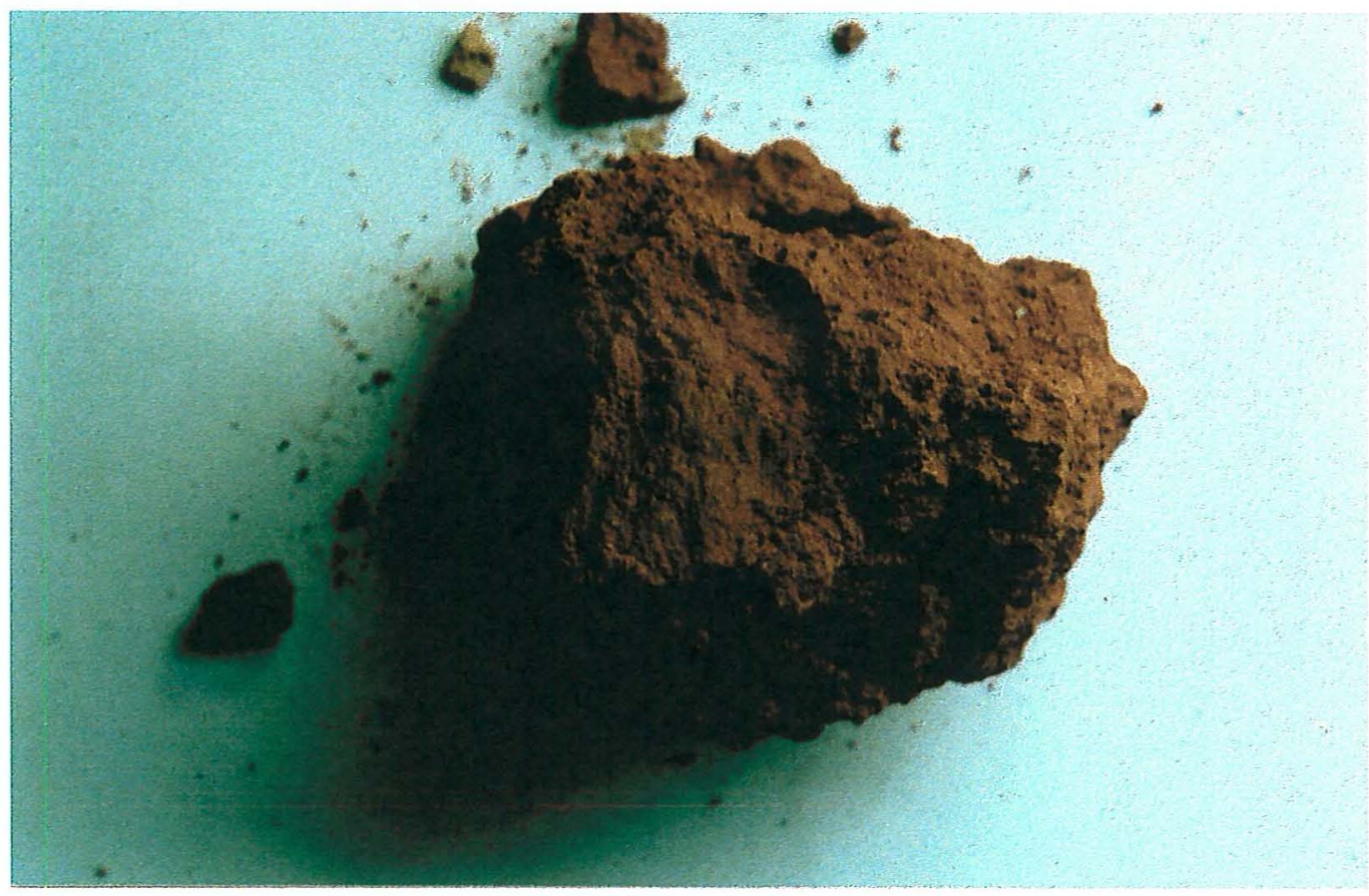

a)

escala de 1:5

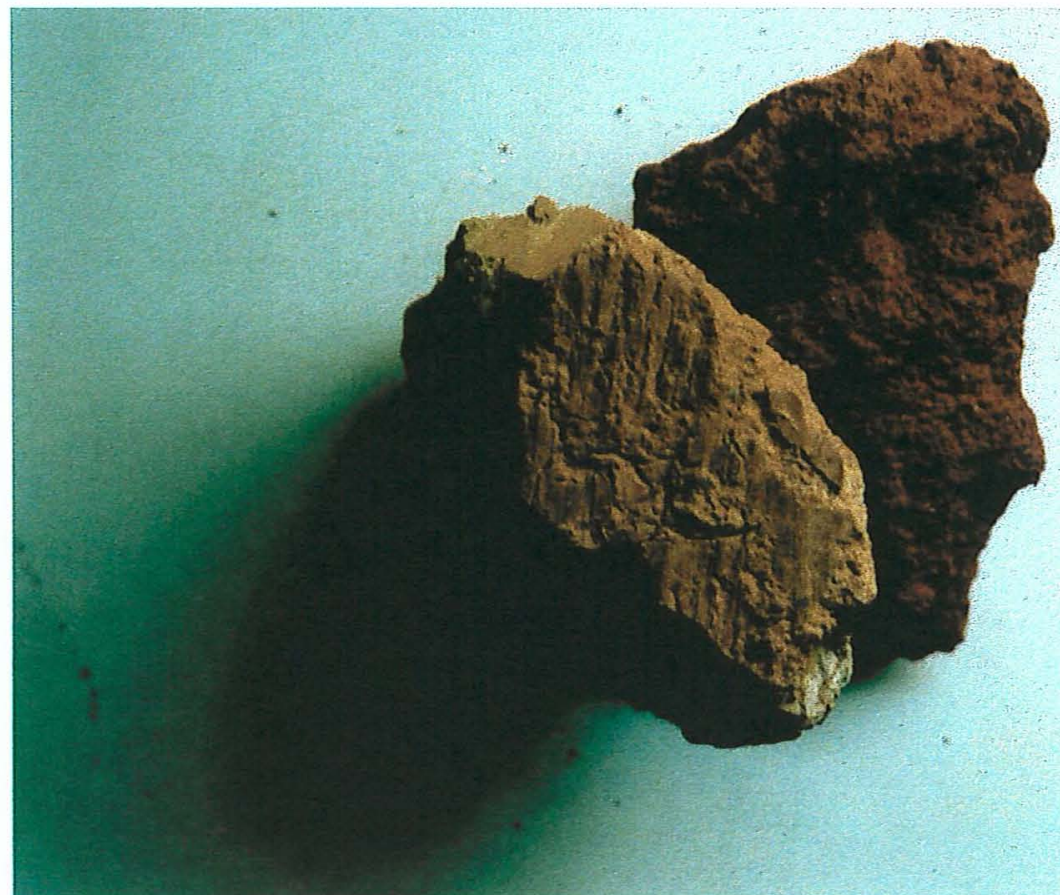

b)

escala de 1:4

Figura 14. Espelho de falha em a) solum e em b) saprolito de Latossolo Vermelho Escuro 


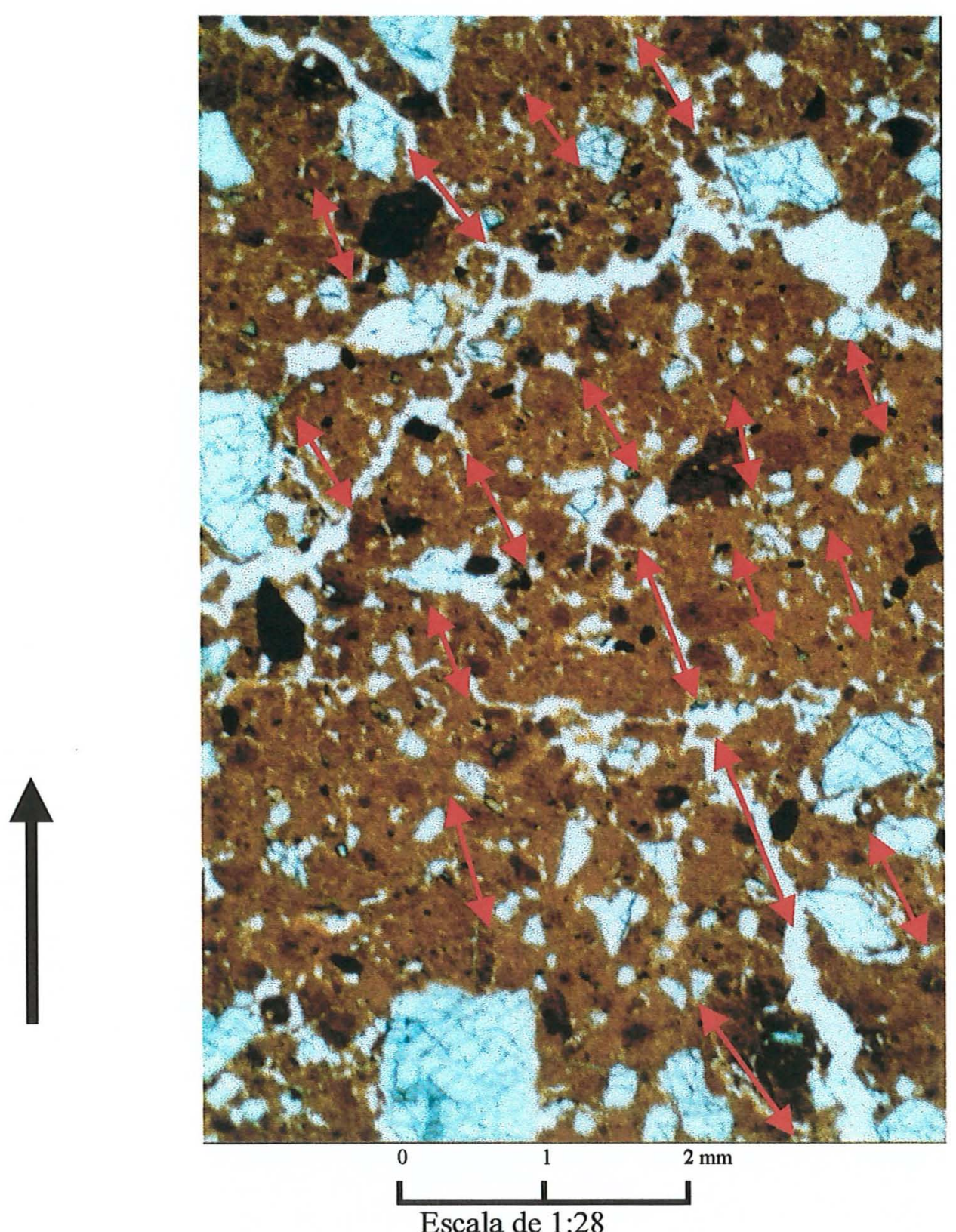

Figura 15. Fotomicrografia do horizonte $\mathrm{AB}$ de $\mathrm{P} 1$. Poros fissurais orientados preferencialmente no sentido SE-NW 


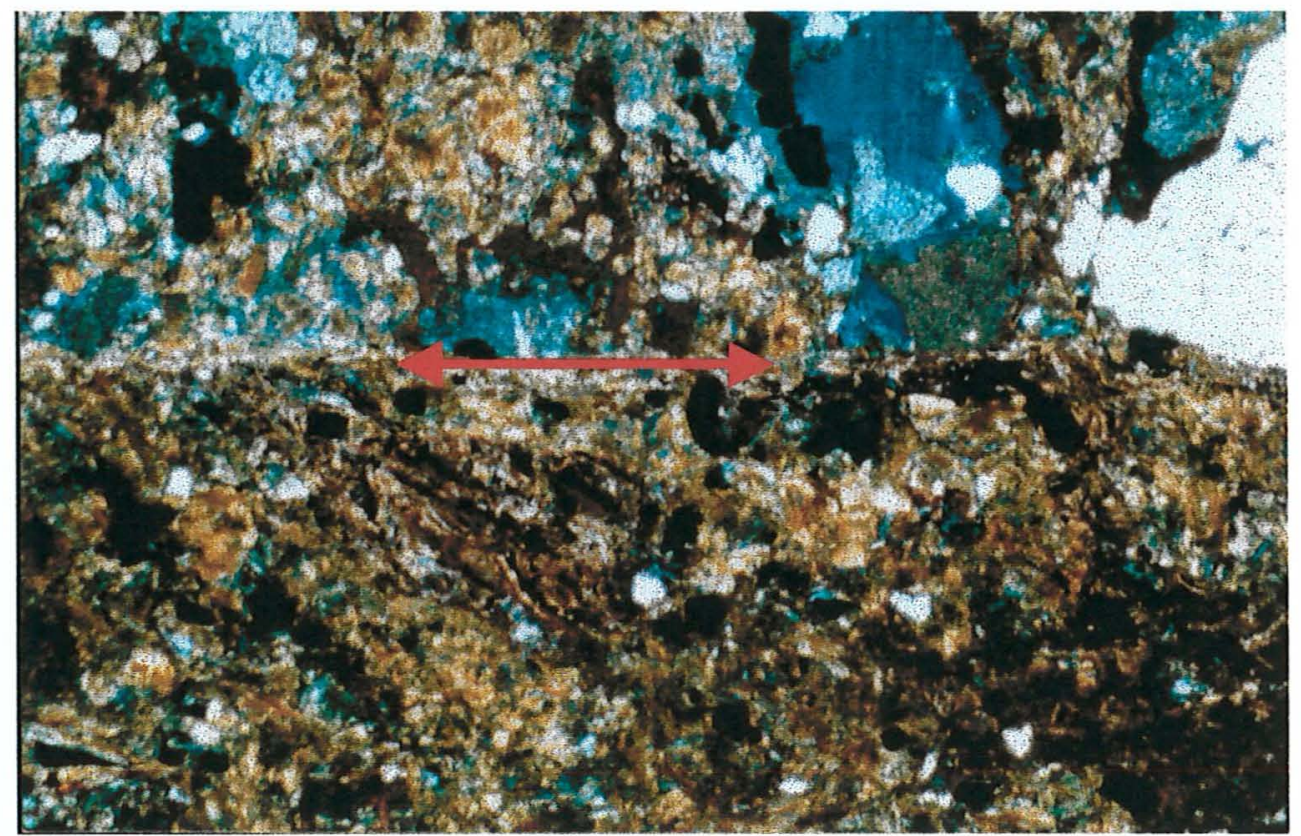

a)

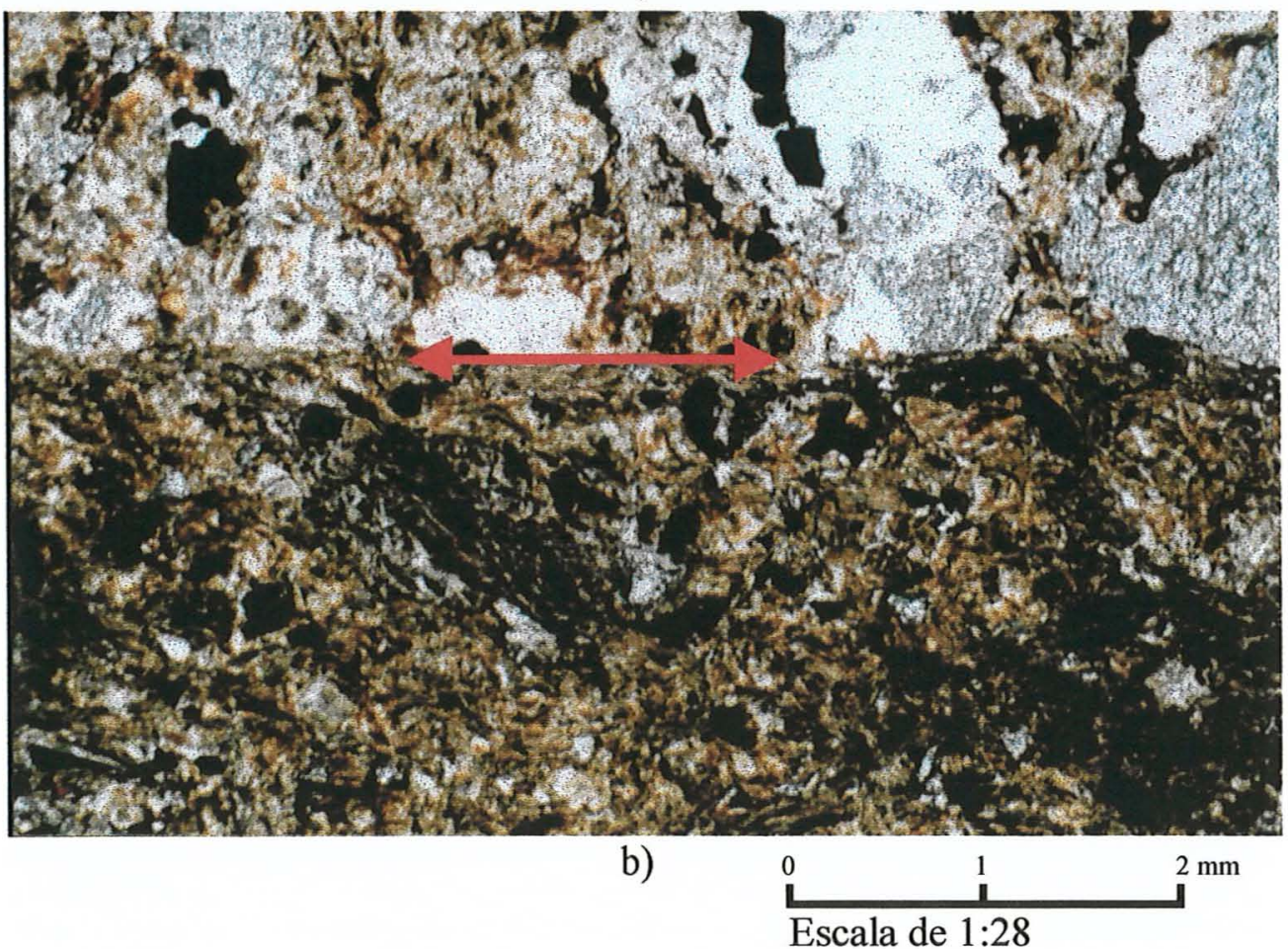

Figura 16. Fotomicrografia do espelho de falha em saprolito. A) luz polarizada com nicóis cruzados; b) luz incidente. Detalhe de um drag (cizalhamento) na parte central da imagem. 

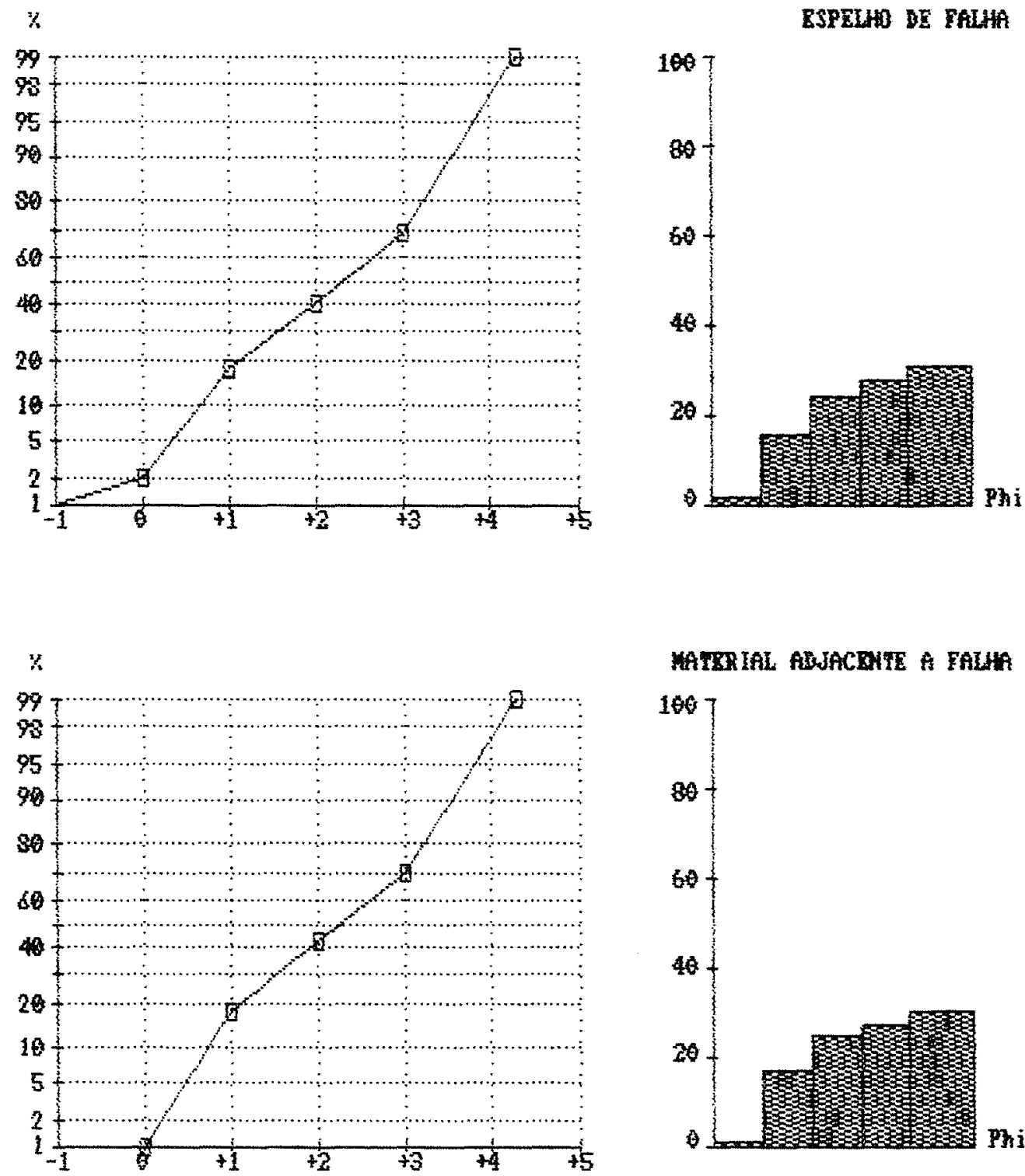

MATER IAL ARJACEMTE A FALHA

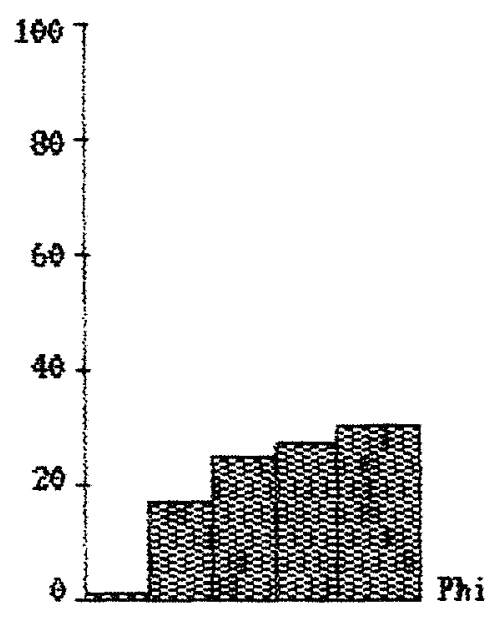

Figura 17 - Distribuição estatística das areias no espelho da falha e no material adjacente. 
Tabela 1- Resultados das análises granulométricas, capacidade de troca e cátions (CTC), da soma de bases (S), da saturação por bases (V) e saturação por alumínio (m) das amostras coletadas na falha geológica e no saprolito ao lado da falha.

\begin{tabular}{|c|c|c|c|c|c|c|c|c|c|c|c|c|}
\hline Amostra & $\begin{array}{l}\text { Areia } \\
\text { Muito } \\
\text { Grossa }\end{array}$ & $\begin{array}{l}\text { Areia } \\
\text { Grossa }\end{array}$ & $\begin{array}{l}\text { Areia } \\
\text { Méctia }\end{array}$ & Areia Fina & $\begin{array}{c}\text { Areia Muito } \\
\text { Fina }\end{array}$ & Areia Total & Silte & Argila & CTC & $\mathrm{S}$ & $\mathrm{V}$ & $\mathrm{m}$ \\
\hline & & & & & $\mathrm{g} \mathrm{kg}^{-1}$ & & & & \multicolumn{2}{|c|}{$\mathrm{cmol}_{\mathrm{c}} \mathrm{kg}^{-1}$} & \multicolumn{2}{|c|}{$\%$} \\
\hline Falha & 7 & 52 & 78 & 93 & 101 & 331 & 619 & 50 & 5,25 & 1,25 & 23,8 & 44,4 \\
\hline $\begin{array}{l}\text { Ao lado } \\
\text { da falha }\end{array}$ & 4 & 67 & 103 & 108 & 123 & 405 & 565 & 30 & 3,12 & 1,01 & 32,6 & 54,2 \\
\hline
\end{tabular}

Feições geomorfológicas também contribuem para comprovar a tectônica ressurgente. Um dos sistemas morfopedológicos estudados (SMI), possui vales estreitos e paralelos, cristas triangulares, interfluvio escarpado com solos rasos e pedregosos, com elevado teor de $\mathrm{Si}$ e $\mathrm{Fe}$, e formas trapezoidais no sopé pontuadas por matacões (Figura 18). Radambrasil (1983), também identificou estas feições nas proximidades da área em foco. Guerra \& Cunha (1995) as utilizam em conjunto para caracterizar escarpas de linha de falha.

A forma e a dinâmica da paisagem regional são consequências da tectônica ressurgente e de modificações climáticas, que ativam o intemperismo e os fenômenos geomorfológicos. Os atributos da cobertura pedológica estão relacionados com a composição química e mineralógica do material de origem, com as condições hídricas da paisagem, com a vegetação e com a fauna do solo, dentre outros. Suas inflluências são decisivas na atuação dos processos pedogenéticos. Mas este quadro não é estanque, havendo interferências mútuas e recíprocas entre os processos que dinamizam a gênese dos solos e da paisagem. 


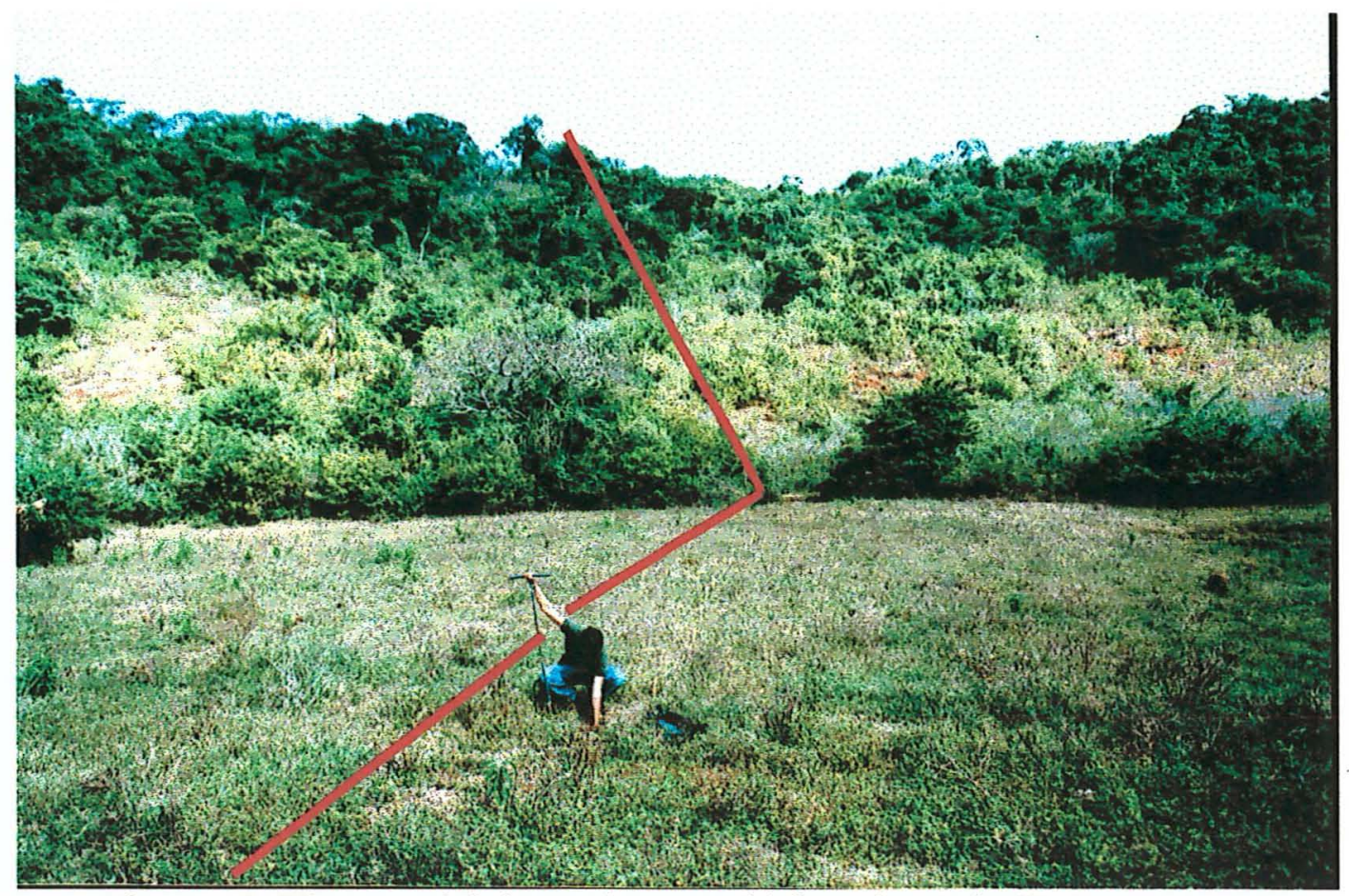

Figura 18. Vista parcial do sopé trapezoidal no front de SMI.

\subsection{Geologia local}

A área em foco foi mapeada na escala de 1:65.000, através de fotointerpretação geológica (Figura 19). Foram encontradas zonas de fratura (trancorrência), foliação geral paralela aos contatos litológicos e lineamentos (falhas, fraturas).

Os complexos geológicos mapeados foram o Complexo Amparo, do Proterozóico e o Complexo Guaxupé, do Arqueano, denominados por Fiori (1979) respectivamente como Grupo Amparo e Complexo Silvianópolis. Baseando-se no trabalho deste autor, foi elaborado o mapa geológico na escala de 1:100.000 ( Figura 20). No Complexo Amparo predominam migmatitos e gnaisses diversos, enquanto que no Complexo de Guaxupé predominam os gnaisses granulíticos e os granulitos básicos (charnoquitos), com teores mais elevados de minerais máficos como piroxênios e biotita.

Apesar de serem rochas muito antigas (do Pré-Cambriano) sua influência nos atributos dos solos que compõe a paisagem atual ainda se faz notar. A ocorrência de saprolito com teores de ferro acima de $150 \mathrm{~g} \mathrm{~kg}^{-1}$ (Tabela 2) somente se dá nas áreas 


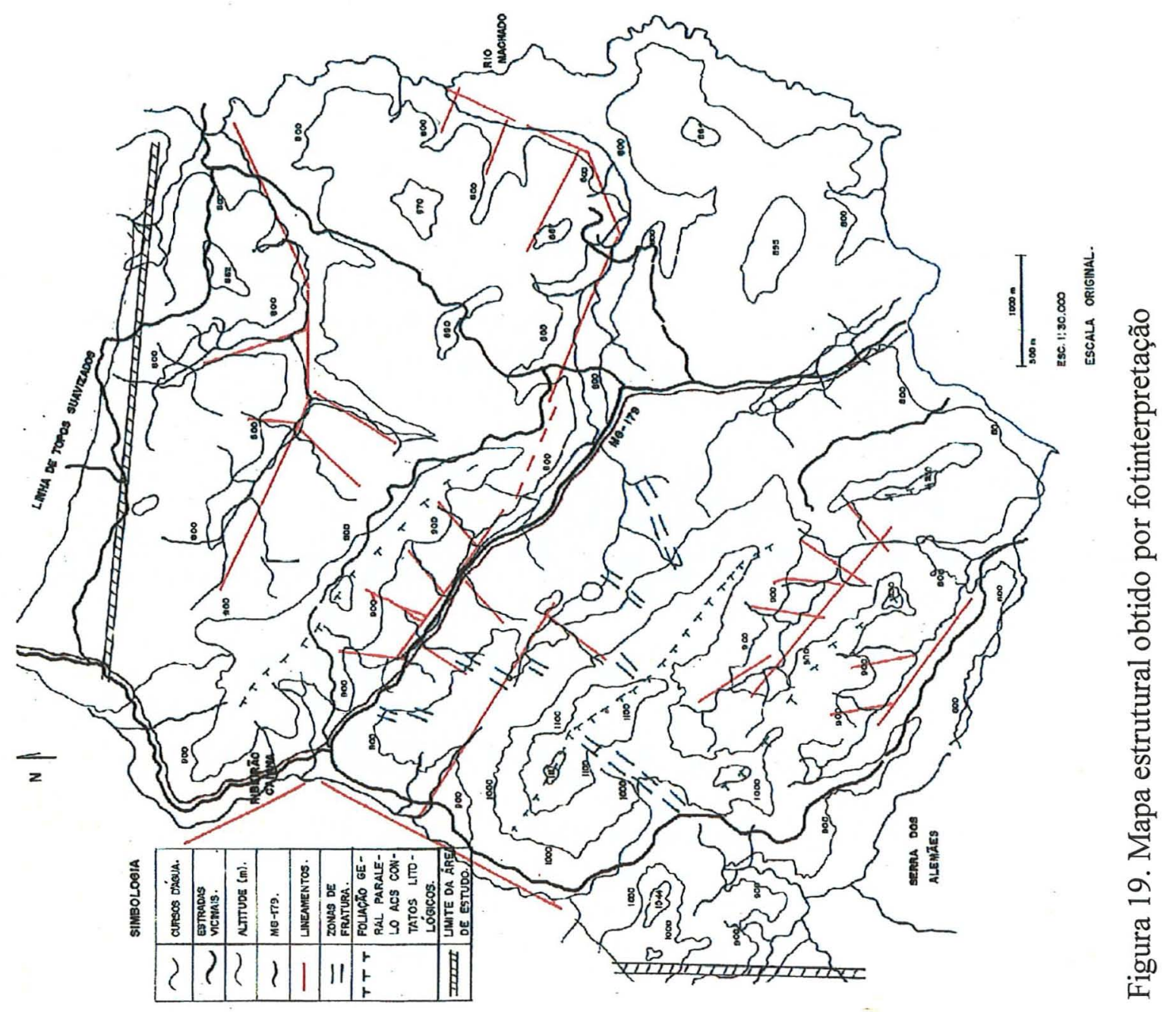




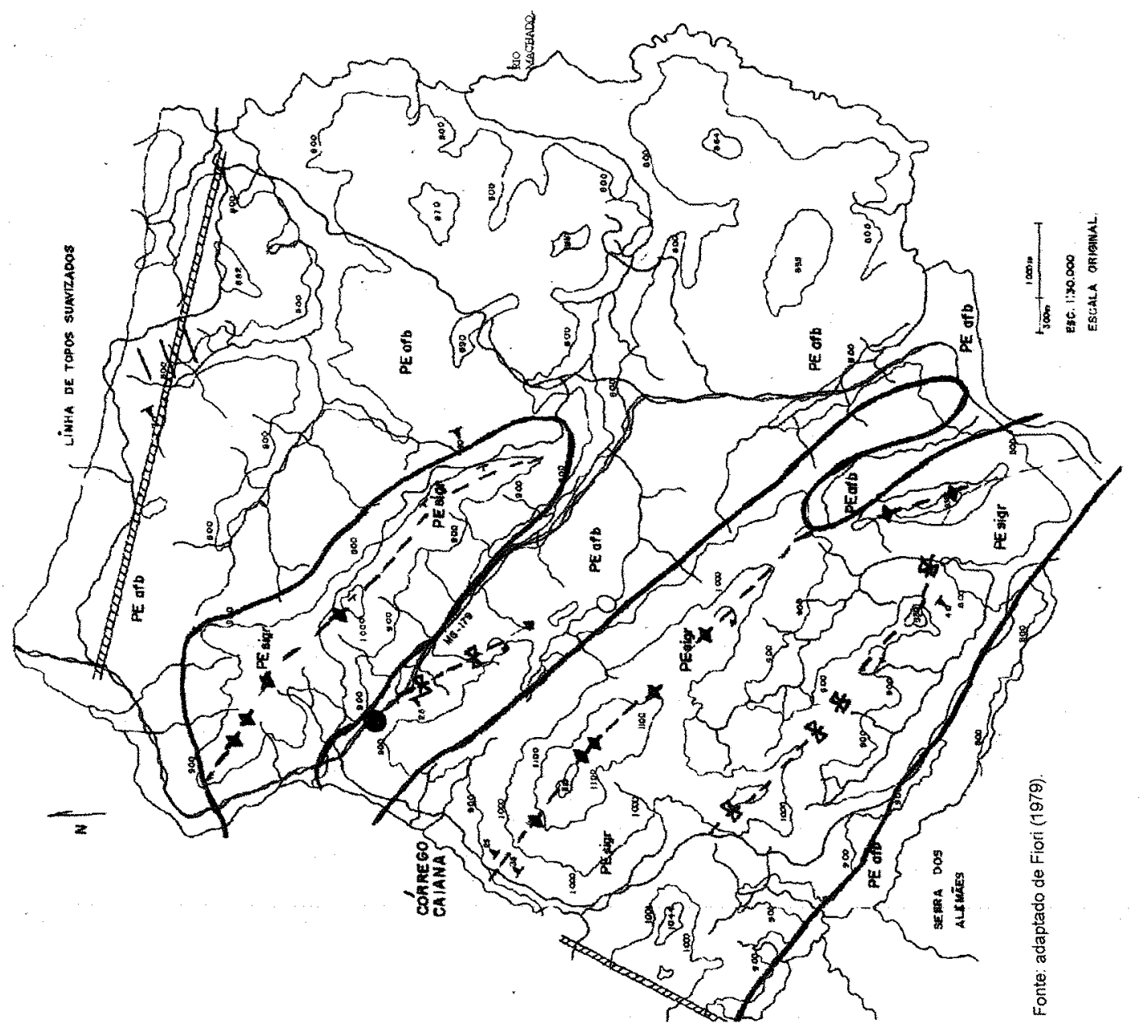

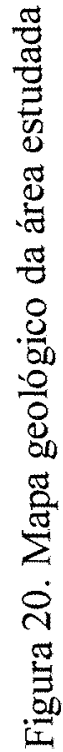

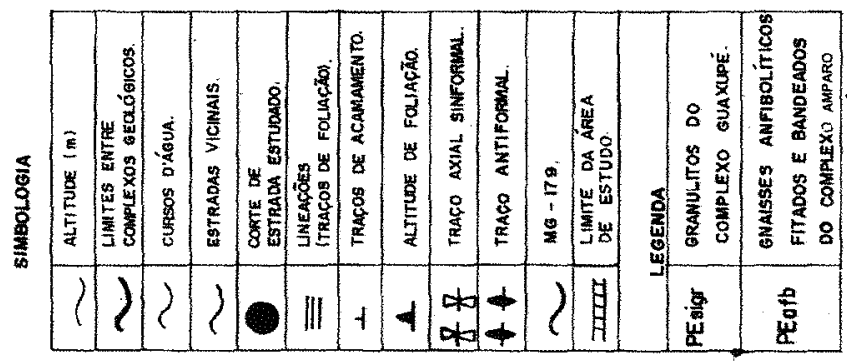


embasadas por rochas do Complexo Guaxupé, que apresentam teores significativos de materiais máficos.

Afloramentos de rochas são encontrados no topo e escarpas (Figura 11) do Sistema Morfológico I (SM), constituídos por gnaisse leucocrático. Na meia-encosta e sopé da face nordeste do SMI, encontram-se também matacões de gnaisse leucocrático e raramente de rochas escuras (charnoquito) e mais pesadas (chamadas pelos moradores locais de "pedra-ferro").

A área do estudo se situa numa região cratônica, que já passou por vários ciclos de metamorfismo, ciclos tectônicos, ciclos de intemperismo e erosão. As características mineralógicas, texturais e estruturais de conjuntos metamórficos expostos pela erosão influem significativamente no relevo esculpido, já que respondem diferentemente aos processos exógenos. Como as principais rochas aflorantes são os gnaisses leucocráticos, com elevado teor de quartzo, e os solos são muito argilosos, com teores significativos de óxidos de ferro, pode-se inferir que estes formaram-se a partir de materiais com teores mais elevados de minerais máficos. Os gnaisses leucocráticos são as rochas mais resistentes ao intemperismo e sua contribuição como material fonte para a formação dos solos da área é menos significativa.

Esta resistência diferencial ao intemperismo leva a formação de soleiras e feições como anfiteatros suspensos (Figura 29 A) passam a compor a paisagem. Esta constatação evidencia o controle estrutural promovido por estas rochas félsicas.

Em um corte de estrada do SMI, onde também foram encontradas falhas, observa-se, a $30 \mathrm{~m}$ da superficie, saprolito de coloração vermelha (2,5 YR 4/6) cavalgando, em forma de bisel, um saprolito amarelado (10YR 6/8). Entre eles ocorre uma faixa de cerca de $30 \mathrm{~cm}$ de espessura, de um material de coloração intermediária (7,5 YR 5/8). A análise granulométrica e o teor de Fe e Ti destes materiais são apresentados na Tabela 2. 
Tabela 2- Resultados da análise granulométrica e do teor de Fe total e Ti total dos diferentes saprolitos encontrados no SMI.

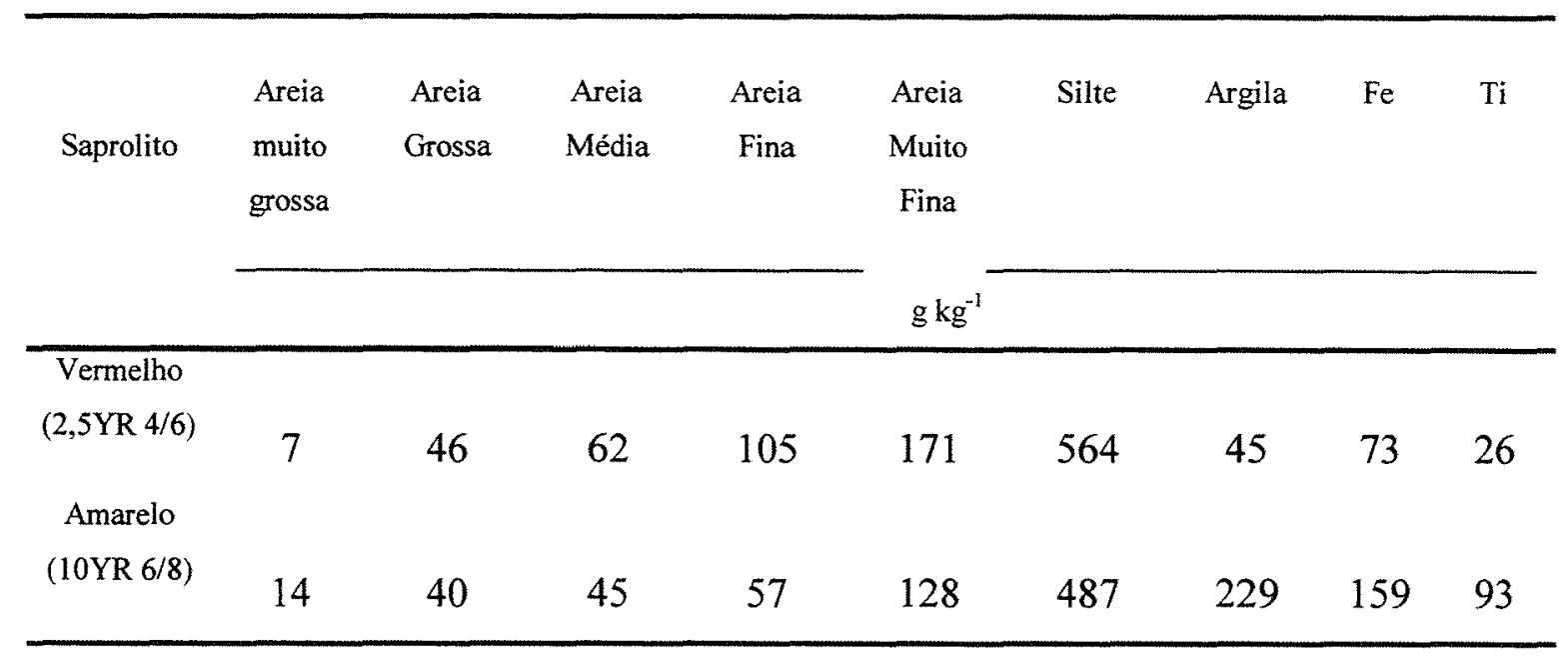

O saprolito amarelo apresenta teores de argila e de silte mais elevados em relação ao saprolito vermelho. A distribuição das areias por tamanho é dada em forma de uma curva de freqüências mesocustica (menor desvio padrão), para o saprolito amarelo e por uma curva de freqüências platicurtica (maior desvio padrão) para o saprolito vermelho (Apêndice 5).

Em relação ao Fe total e Ti total, verifica-se que seus teores são muitos mais elevados no saprolito amarelo. Comparando-se estes teores com os valores encontrados por Radambrasil (1983) para Fe e Ti em rochas félsicas e máficas da região, pode-se inferir que o saprolito amarelo foi originado pela meteorização de uma rocha máfica. Os teores mais elevados de argila e fragmentos esparsos de magnetita também são evidências deste modelo. Vidal Torrado (1994), encontrou saprolito amarelo com teores elevados de Fe e Ti, originado de rocha máfica (diabásio). Os granulitos são apontados na literatura como os equivalentes pré-cambrianos dos basaltos.

O material de origem dos solos da área estudada, que possuem em média teores de argila em torno de $600 \mathrm{~g} \mathrm{~kg}^{-1}$ (Apêndice 2) é formado predominantemente pelo produto da meteorização de rochas com maiores teores de minerais máficos do que os gnaisses leucocráticos que afloram na área. Esta constatação é baseada na análise da composição química de rochas félsicas semelhantes às encontradas na superficie 
( Radambrasil, 1983). Elas não apresentam teores suficientes de minerais primários como feldspatos, piroxênios e anfibólios para originarem uma cobertura pedológica com teores de argila, de Fe e de Ti tão elevados. A presença de quartzo, feldspato e mica na fração silte dos solos da região (Apêndice 4) reforça esta hipótese.

\subsection{Geomorfologia e evolução do relevo}

\subsubsection{Descrição do relevo regional}

O mapa geomorfológico da área do estudo (Figura 21), que é representativo de grande extensão territorial do Sul de Minas Gerais, mostra feições de relevo que caracterizam o controle estrutural e a atuação de processos geomorfológicos como erosão e movimentos de massa, além da ação da erosão geoquímica.

Esta área corresponde ao contato entre uma superficie montanhosa dissecada com cotas topográficas bem heterogêneas (variando de $1.117 \mathrm{~m}$ a $895 \mathrm{~m}$ ) e uma superficie aplainada de topografia suavizada com pendentes longas (até $1.500 \mathrm{~m}$ ) e cotas oscilando entre 890 e $790 \mathrm{~m}$. Estas superficies estão relacionadas respectivamente a rochas do Complexo Guaxupé e a rochas do Complexo Amparo.

A superficie montanhosa dissecada ocorre predominantemente no oeste e sudoeste da área deste estudo e ao sul da região. Apresenta 5 cristas onde afloram rochas félsicas, de orientação SE-NW, sendo que uma delas se destaca pela altitude, continuidade e feições de relevo que se assemelham a outras cristas da paisagem regional. Por esta representatividade, nela foi instalado o aqui denominado Sistema Morfológico I (SMI), uma das unidades básicas deste estudo ( Figura 5). A encosta nordeste (front) do SMI é marcada pela alta declividade, pela presença de escarpas com afloramentos de rocha (Figura 11) e por deslizamentos. A encosta sudoeste (reverso) deste mesmo sistema caracteriza-se por apresentar uma série de interfluvios separados por vales estreitos e profundos, com cachoeiras nas soleiras, formando anfiteatros suspensos (Figura 29 A) (controle estrutural). Estes interflúvios apresentam relevo ondulado, profunda cobertura pedológica e horizonte superficial espesso e escuro, rico em matéria 


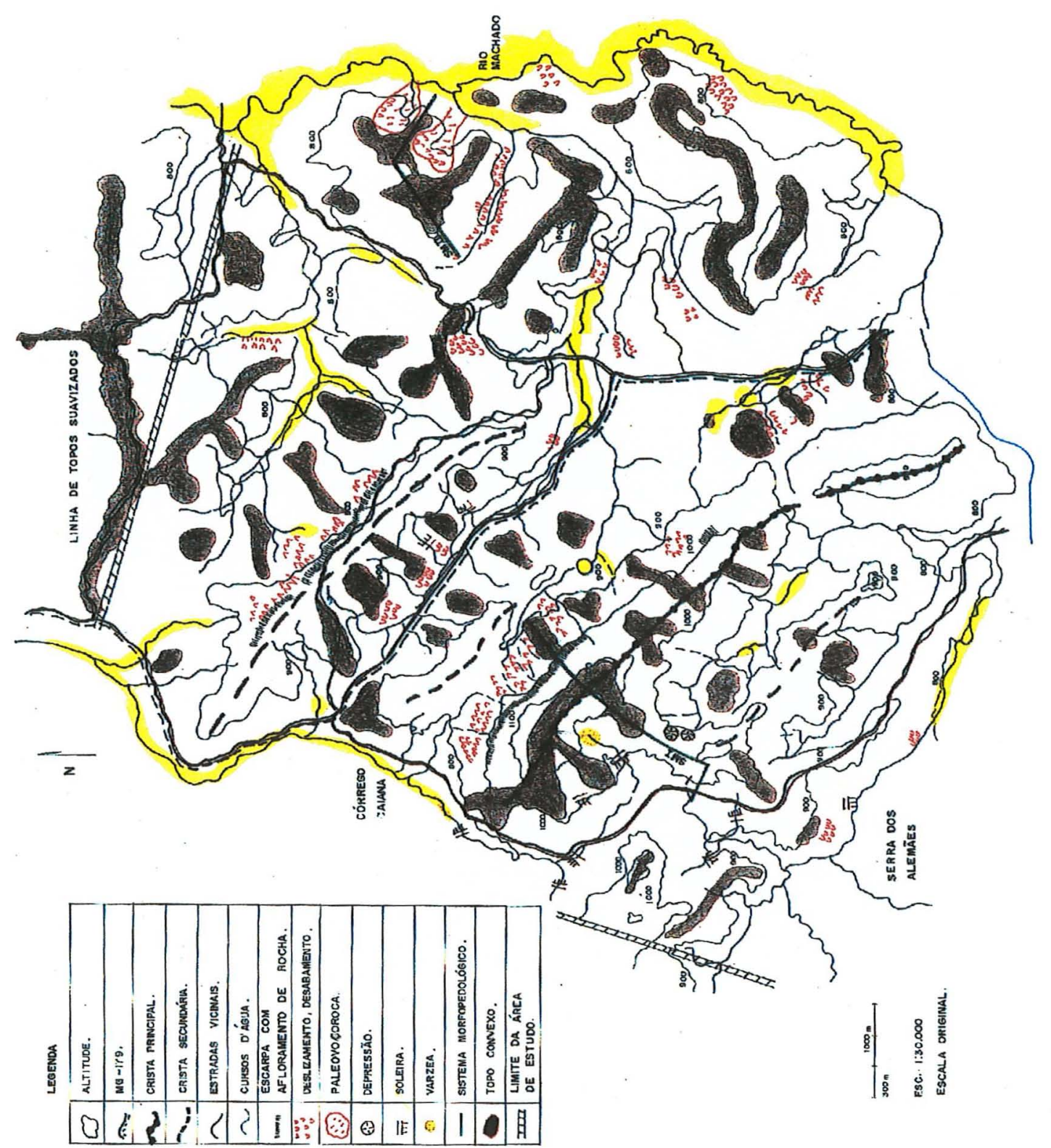

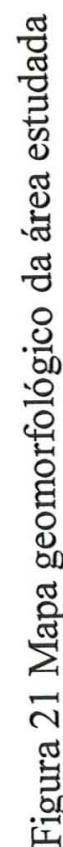


orgânica e carvão e com intensa atividade biológica. Em seu sopé ocorrem depressões semi-fechadas (Figura $29 \mathrm{~B}$ ) em forma de anfiteatro, que podem estar relacionadas ao nascimento de uma cabeceira de drenagem por erosão geoquímica.

A superficie aplainada de topografia suavizada ocorre notadamente a leste da área de estudo e ao norte da região, sendo delimitada a leste pelo rio Machado, principal nível de base local. É caracterizada por extensas colinas convexo-côncavas de pendentes longas, com topos suave ondulados, encostas onduladas, vales estreitos e rede de drenagem de menor densidade em relação a superfície descrita anteriormente. A exceção para vale estreito é o vale do rio Machado, que localmente se destaca pela sua largura, chegando a alcançar $500 \mathrm{~m}$. Estas colinas apresentam convexidade na posição de ombro, são retilíneo-côncavas na meia-encosta e côncavas no sopé. Paleovoçorocas, caracterizadas pela sua estabilidade e por sua colonização por vegetação florestal, também foram identificadas nestas superficie.

A cobertura pedológica desta superficie é profunda e, em algumas delas, são encontrados, nas posições de topo e ombro, horizonte superficial espesso, escuro, rico em matéria orgânica e carvão e intensa atividade biológica. Em uma delas, que se inicia em um topo com horizonte superficial espesso e escuro e termina em um tributário de $2^{\mathrm{a}}$ ordem do Rio Machado por uma direção e por outra direção no próprio rio Machado, foi instalado o Sistema Morfopedológico II (SMII), a segunda unidade básica deste estudo (Figura 6).

\subsubsection{Modelo de evolução do relevo}

O estudo e a descrição detalhada no campo das feições e atributos dos Sistemas Morfológicos I e II, complementado por análises de laboratório e trabalhos de escritório permitiram estabelecer um modelo hipotético de evolução do relevo, que se iniciaria no Mioceno Superior e termina no tempo presente e que guarda influências recíprocas entre os solos e as feições da paisagem. Esta descrição é dada a seguir.

Os topos do SMI são formados por cristas com alinhamento NW-SE onde ocorrem afloramentos de rochas (gnaisse leucocrático) associados a litossolos. Cinqüenta 
a cem metros abaixo, na sentido NE, onde as declividades situam-se ao redor de $30 \%$, inicia-se uma cobertura pedológica espessa, vermelho-escura, formada por Podzólico Vermelho-Escuro associado a esparsos calhaus e matacões. Esta feição é interrompida bruscamente por uma escarpa de rocha fëlsica, que se repete $200 \mathrm{~m}$ abaixo. Entre as escarpas são encontrados solos Podzólico Vermelho-Escuro pouco profundos, associados a Solos Litólicos e afloramentos da rocha, em declives em torno de $45 \%$.

No sopé desta vertente ocorrem matacões rolados de gnaisse leucocrático, solos mais profundos com cascalhos e calhaus ao longo do perfil e formas superficiais trapezoidais com afloramento de rocha no ombro, formando uma soleira localizada. Após esta soleira, nova vertente a inicia, terminando no riacho à juzante. Estas feições correspondem a escarpas de linha de falhas (Guerra \& Cunha, 1995) e, juntamente com a cobertura pedológica, sugerem a retomada do basculamento de blocos no Terciário, adicionando energia ao sistema por mudança do nível de base local. Isto provocaria, juntamente com as mudanças climáticas, o recuo da encosta pela ação da gravidade (movimentos de massa) e da água, com conseqüente rolamento de calhaus, matacões e mesmo bolders de rochas félsicas, de acordo com o modelo de Ruhe (1967). Tal modelo considera a maior retirada de material das partes mais elevadas com agradação do sopé. Escarpas (controle estrutural), solos rasos na parte superior da vertente, solos profundos com matacões à superfície e calhaus ao longo do perfil e feições trapezoidais no sopé corroboram o modelo de Ruhe.

A hipótese do basculamento de blocos é fortalecida pela presença de solos pouco profundos e vermelhos (supostamente originados dos charnoquitos) entre 2 escarpas de rochas félsicas, que funcionariam como barreira que minimizaria os movimentos de massa e erosão, favorecendo o intemperismo com conseqüente formação de solos profundos. Somente uma mudança do nível de base local e dos ângulos de equilibrio entre a cobertura pedológica e o relevo interno poderiam propiciar a passagem desta cobertura por sobre a barreira estrutural com conseqüente deslizamento deste material até o sopé, onde seria parcialmente depositado na forma de terraços trapezoidais de declives suaves (em forma de 4 a $8 \%$ ), pois os afloramentos de ombro do terraço, afastados em cerca de $200 \mathrm{~m}$ da encosta barraram parcialmente o material movimentado. 
De acordo com os dados do Apêndice 5, verifica-se que o perfil de solo descrito abaixo do topo e acima da primeira escarpa (P7) apresenta a mesma distribuição de areias até $1 \mathrm{~m}$ de profundidade em relação ao perfil descrito no terraço trapezoidal (P8), apesar deste apresentar horizonte A mais espesso e arenoso. Estes atributos sugerem uma significativa contribuição de material das partes superiores da vertente na formação da cobertura pedológica de sopé, pois movimentos de massa e a erosão hídrica transportariam a camada superficial dos solos a montante e a depositariam no terraço, causando o espessamento do horizonte A. A presença de fragmentos arredondados e arestados de gnaisse ao longo de P8 é outra evidência destes processos.

A vertente SW do SMI inicia-se nos afloramentos de rocha da crista, termina nas depressões semi-fechadas do sopé e sua extensão é de $800 \mathrm{~m}$. As declividades variam de $8 \%$ nas proximidades dos sopés a $22 \%$ nas meias-encostas. A presença de muitos fragmentos de carvão ao longo das coberturas pedológicas é generalizada em todas as posições da vertente. Uma camada de gnaisses ferruginizados ocorre a $50 \mathrm{~m}$ do topo, em uma profundidade de $0,7 \mathrm{~m}$. Esta mesma camada foi alcançada com o trado em $\mathrm{P}_{1}$ a $4,0 \mathrm{~m}$ de profundidade e em P2 a 6,9m de profundidade. A 100m abaixo de P2 ela surge a $0,65 \mathrm{~m}$ de profundidade (Figura 22), coincidindo com um anfiteatro suspenso formado pelo controle estrutural.

Dentre as hipóteses aventadas na literatura para explicar a gênese da linhas de pedras (alóctone, por remonte vertical devido a ação da fauna do solo, residual, residual aliada a movimentos de massa e combinação de hipóteses), a residual a partir de materiais mais resistentes ao intemperismo seria a mais provável para a linha de pedras em questão.

Faniram \& Jeje (1983) abordam o conceito do intemperismo residual para explicar as linhas de pedras como produtos residuais do intemperismo químico, que progride para o interior do maciço rochoso. No presente estudo, lentes de gnaissses leucocráticos (comuns em toda paisagem), mais resistentes ao intemperismo permaneceriam no regolito como produto do intemperismo residual, sendo envolvidas por ferro mobilizado a partir das camadas superiores, veiculado pela água de percolação e pelo fluxo lateral subsuperficial. Carapaças não se formariam pela umidade constante recebida por este material, o que minimiza a oxidação do ferro e o endurecimento. Tal 


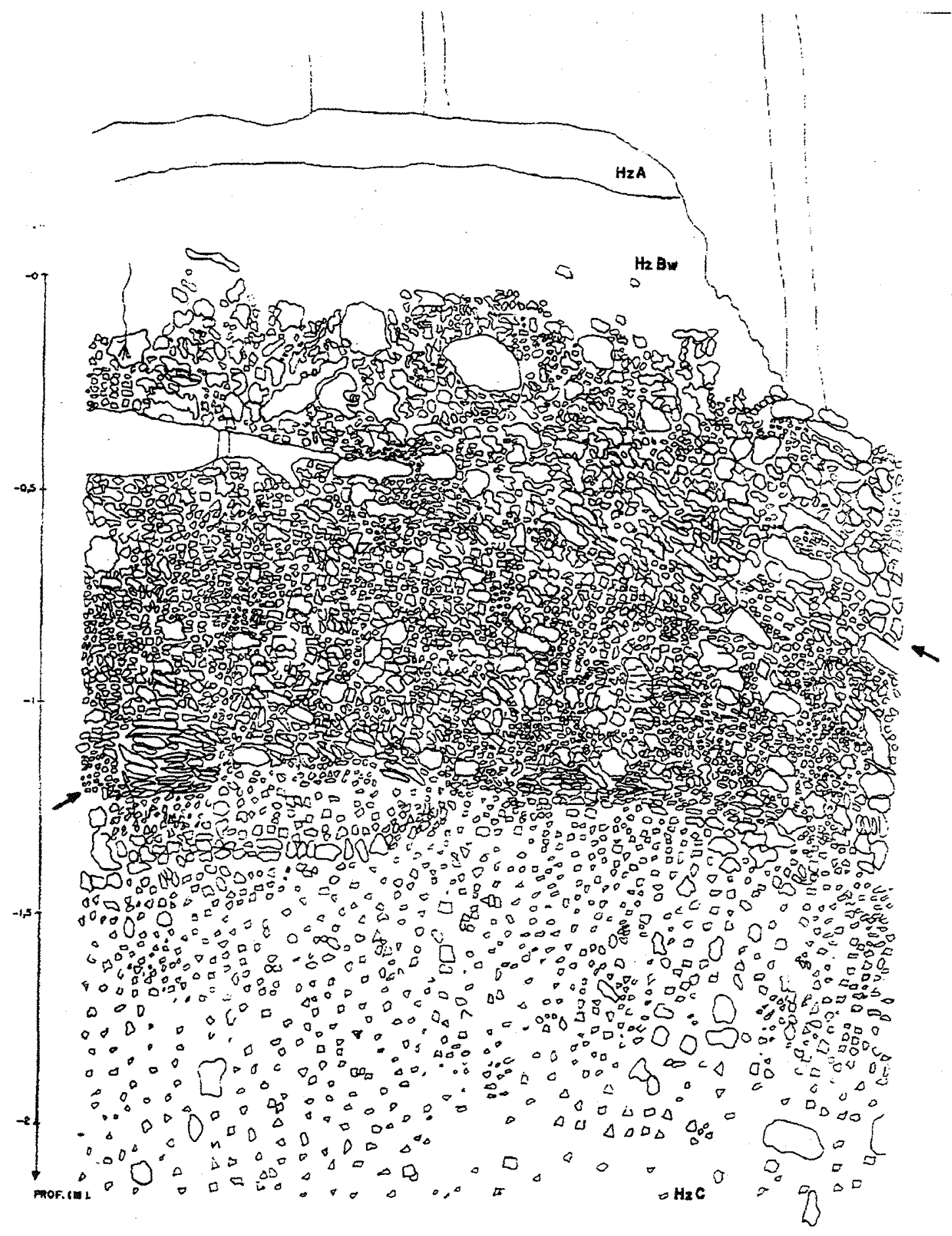

ESCALA I:T,56

ORIGALAL

Figura 22. Linhas de pedra de origem residual no SMI. Setas indicam grau de filiação e a orientação dos fragmentos de ginaisse ferruginoso 
fato pode ser um indício da não ocorrência de clima semi-árido partir do Terciário Inferior, na região enfocada. Fatores que evidenciam a gênese residual desta linha de pedras seriam a falta de seleção dos fragmentos de rocha, bem como suas formas de ocorrência (achatadas, arredondadas, arestadas, etc.).

A forma atual da "Stone line" (Figura 5), acompanhando o relevo interno, sugere a atuação da tectônica ressurgente, onde os movimentos de blocos de rocha no interior da litosfera levariam a fragmentação da lente de gnaisse mais superficial favorecendo a movimentação de água e a ação da fauna do solo em seu interior.

Bigarella et al. (1994), argumenta que quando existe uma considerável quantidade de matriz entre os fenoclástos, é mais aplicável a teoria da perturbação faunística. Na linha de pedras em questão, a quantidade de matriz entre os fenoclastos é desprezível e a orientação destes é regular, e acompanha a orientação dos planos de foliação das rochas do local, obtidos nos mapas geológicos. Detalhes da Figura 22 evidenciam a degradação de matacões de gnaisse em fragmentos menores. A distribuição dos fragmentos sugere o intemperismo "in situ".

Estas constatações não se ajustam ao modelo proposto por Eschembrenner (1996), segundo o qual a linha de pedras pode ser formada pelo transporte de materiais finos perfil acima, juntamente com a descida de seixos pelo perfil, devido a construção de um grande número de canais e galerias. Porém, existem linhas estreitas de gnaisse ferruginizado no solum que podem ser explicadas por este modelo.

Entre o topo e o controle estrutural que gerou o anfiteatro suspenso são encontrados latossolos com horizonte superficial húmico (espesso, escuro e rico em matéria orgânica) de espessura superior a $2 \mathrm{~m}$ e solum com até $7 \mathrm{~m}$ de profundidade. $\mathrm{O}$ relevo é escalonado, com dois segmentos de encosta convexos sendo sucedidos por dois segmentos côncavos, onde o declive oscila entre 22 e $8 \%$. Na superficie do segundo segmento convexo foi observada a presença de uma camada de $8 \mathrm{~cm}$ de espessura, de cores mais claras e elevado teor de areia total. A origem desta camada pode estar relacionada a deposição seletiva de partículas de areia devido a diminuição de velocidade da enxurrada (depósito tecnogênico), ou pelo carreamento de materiais finos para 
preenchimento de biopedotúbulos nas camadas inferiores do solo, levado a cabo por térmitas, de acordo com o modelo preconizado por Eschenbrenner (1988).

Neste segmento de encosta foram feitas duas tradagens profundas, sendo uma em P1 (fase cônvexa), que alcançou 4m de profundidade e outra em P2 (fase concava), que alcançou $7 \mathrm{~m}$ de profundidade. Nesta tradagens observou-se mudança gradativa de cor do solum para o saprolito, passando de amarelo-avermelhada para vermelho amarelada. Esparsos fragmentos de gnaisse ferruginizado, três linhas tênues destes fragmentos de diâmetro menor que $1 \mathrm{~cm}$ em P1 (a 2,6; a 3,15 e a 3,5m) e duas linhas tênues em P2 (a 3,95m e a 5,0m) foram encontrados. Intensa atividade biológica também foi registrada nesta cobertura.

Estas características, juntamente com atributos morfológicos, micromorfológicos, mineralógicos e químicos destes solos balisam a ocorrência de 3 fenômenos interativos neste segmento de encosta, a partir do Mioceno Superior, tempo este que marca o início de uma fase mais úmida. O primeiro deles é a formação de um espesso manto latossólico pelo intemperismo em épocas mais úmidas que a atual, provavelmente coberto "a posteriori" por uma vegetação densa e intensamente trabalhado pela ação da fauna do solo.

O segundo fenômeno seria a reativação do basculamento de blocos, a partir do Mioceno Médio, causando transporte a curta distância, por movimentos de massa, de porções da linha de pedras do topo e do manto latossólico, misturando-os ao longo da vertente e soterrando horizontes superficiais (formando horizontes sômbricos).

O terceiro fenômeno está relacionado com uma intensa atividade da fauna do solo, que constrói moradias e canais por todo o perfil, remontando materiais para a superficie desde o início do Terciário até os dias atuais. Estas atividades podem ser responsáveis pela formação das tênues linhas de gnaisses ao longo dos solos e pela presença ainda hoje de horizontes sômbricos ao longo deste seguimento de encosta.

A distribuição de areias de 11 amostras tomadas seqüêncialmente até $4 \mathrm{~m}$ de profundidade em P1 e de 15 amostras tomadas seqüêncialmente até $6,9 \mathrm{~m}$ de profundidade em P2 é semelhante (Apêndice 5), predominando curvas de distribuição de freqüências platicúrticas a mesocúrticas, com desvio padrão elevado. A exceção fica para 
a camada de 0 a $13 \mathrm{~cm}$ de $\mathrm{P} 1$, que é muito platicúrtica, com elevado teor de areia muito grossa, que pode ser proveniente da alteração do gnaisse félsico do topo.

Estes resultados apoiam a hipótese de que a cobertura pedológica deste segmento de encosta começou a ser formada no início do Terciário, passando pelo espessamento do manto latossólico, no Mioceno Superior, seguido de transporte a curta distância no Mioceno médio, sofrendo ação contínua da fauna do solo. Sua mineralogia caulinítico-gibbsítica de fração argila, sua cor e espessura reforçam esta hipótese, que será rediscutida no capítulo referente a solos.

Após o controle estrutural inicia-se novo segmento de encosta côncavo, com $420 \mathrm{~m}$ de extensão, que termina em uma depressão semi-fechada (Figura 29 B). A declividade no início da concavidade é de $22 \%$ e vai diminuindo lentamente até atingir $8 \%$ nas bordas da depressão semi-fechada. Este segmento também apresenta uma profunda cobertura pedológica latossólica, com horizonte superficial espesso e escuro. Em seu terço inferior foi realizada uma tradagem de $6 \mathrm{~m}$ de profundidade (P3).

A depressão apresenta forma anfiteátrica semi-circular, com diâmetro de boca de $51 \mathrm{~m}$ e diâmetro de fundo (piso) de $35 \mathrm{~m}$. Suas bordas apresentam declividade média de $44 \%$ e $28 \mathrm{~m}$ de talude. Possui uma pequena abertura a sudoeste, onde não existem vestígios de sulcos de erosão ou leito de riacho, que grada paulatinamente para uma encosta de declividades elevadas, que também não apresenta sulcos de erosão. Tradagens de $2 \mathrm{~m}$ de profundidade foram realizadas nas paredes e no fundo desta feição, obtendo-se material pedológico com atributos morfológicos, físicos e químicos semelhantes aos atributos do material descrito em P3 (latossolo), porém com horizonte superficial escuro menos espesso. A drenagem desta cobertura pedológica é acentuada e não existem vestígios de inundação mesmo que periódica (mosqueamentos, gleização, etc).

Agumas hipóteses podem ser lançadas a respeito da gênese destas depressões. Para Guerra \& Cunha (1996) estas depressões em anfiteatro sugerem o nascimento de cabeceiras de drenagem, que são capazes de reproduzir, em sua estrutura subsuperficial e na conformação geométrica, os processos que operaram na evolução da paisagem. Estes processos estão relacionados com erosão geoquímica diferencial, que ocorre preferencialmente em áreas de contato entre litologias distintas, cujas respostas ao 
intemperismo são diferenciadas. Estas áreas de contato são descritas na literatura como vias preferenciais para a ocorrência de fraturas e falhas (Mioto, 1990, Hasui, 1990, Saadi, 1990 e 1991). Analisando-se as depressões por este ângulo, pode-se interpretá-las também como feições relacionadas a falhamentos, corroborando a hipótese da ação da tectônica ressurgente no esculpimento do relevo atual.

Entre o controle estrutural e a depressão semi-fechada, a cobertura pedológica latossólica apresenta atributos que reforçam a hipótese de transporte a curta distância por movimentos de massa, ativados pela tectônica ressurgente. A cobertura, descrita em P3, é formada por um Latossolo Húmico, cujas cores amareladas passando para amarelo avermelhadas até 4,0m de profundidade, se assemelham às cores encontradas em P1 e P2, mas a densidade do solo (Apêndice 2) aumenta significativamente. Até 4,0m de profundidade, a distribuição de areias, a mineralogia da fração argila cauliníticogibbsítica, e a relação Ti/Zr oscilando entre 7,61 e 9,07 o teor de ferro maior $63 \mathrm{~g} \mathrm{~kg}^{-1}$ (Apêndice 4), também são semelhantes às encontradas em P1 e P2. Porém, a partir de $4,0 \mathrm{~m}$ de profundidade, as cores do regolito passam para vermelhas, a mineralogia da fração argila para a caulinítica e a relação Ti/Zr eleva-se para entre 12,5 e 13,7 (Figura 23), os teores de ferro caem para menos de $61 \mathrm{~g} \mathrm{~kg}^{-1}$ e a distribuição de areias modificase, com diminuição do teor de areia grossa e aumento da areia total (Apêndice 2). Estes atributos são semelhantes aos encontrados em P4 (Latossolo Vermelho-Escuro, que se situa no sopé da colina iniciada após a depressão semi-fechada) e diferem significativamente dos valores encontrados para estes mesmos atributos em $\mathrm{P}_{1}$ e $\mathrm{P}_{2}$. As diferenças na relação Ti/Zr são superiores àquelas usadas por Drees \& Wilding (1973) como indicadores de descontinuidades litológicas. Estas evidências apontam para uma descontinuidade de materiais no regolito descrito e amostrado em P3.

Até cerca de 4,0m de profundidade o material de P3 é proveniente do segmento superior da encosta, transportado a curta distância por movimentos de massa, o que gerou um adensamento do material, detectado pelas análises de densidade do solo e micromorfológica (Figura 24). 


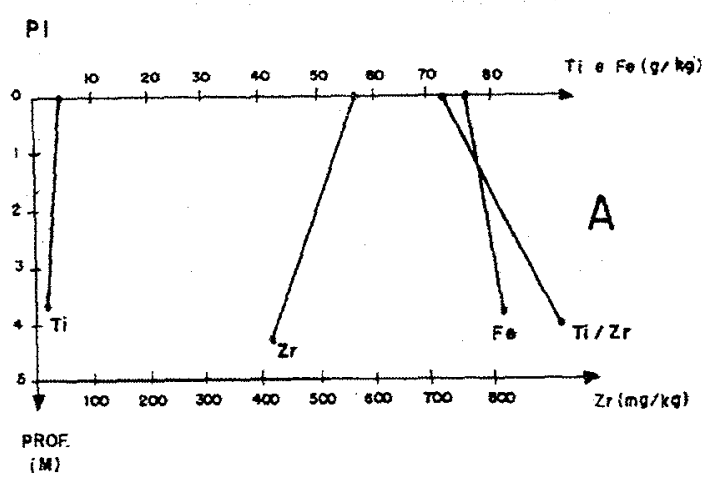

P 2
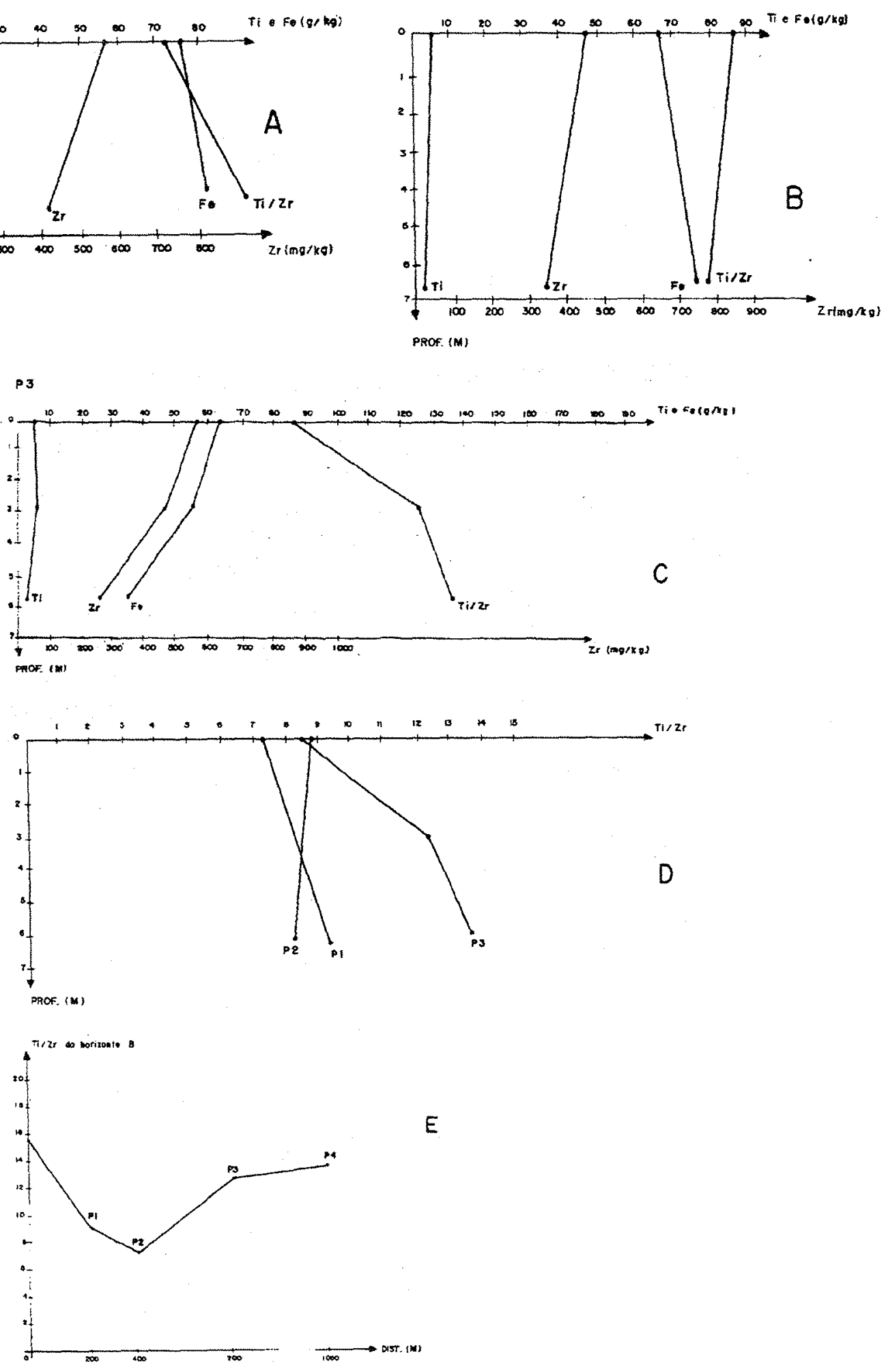

Figura 23. Teores de Ti e Fe de P1 (A), P2 (B), P3 (C), relação Ti/Zr do horizonte $\mathrm{BW}$ de $\mathrm{P} 1, \mathrm{P} 2$ e P3 (D) e variação da relação Ti/Zr em SMII 


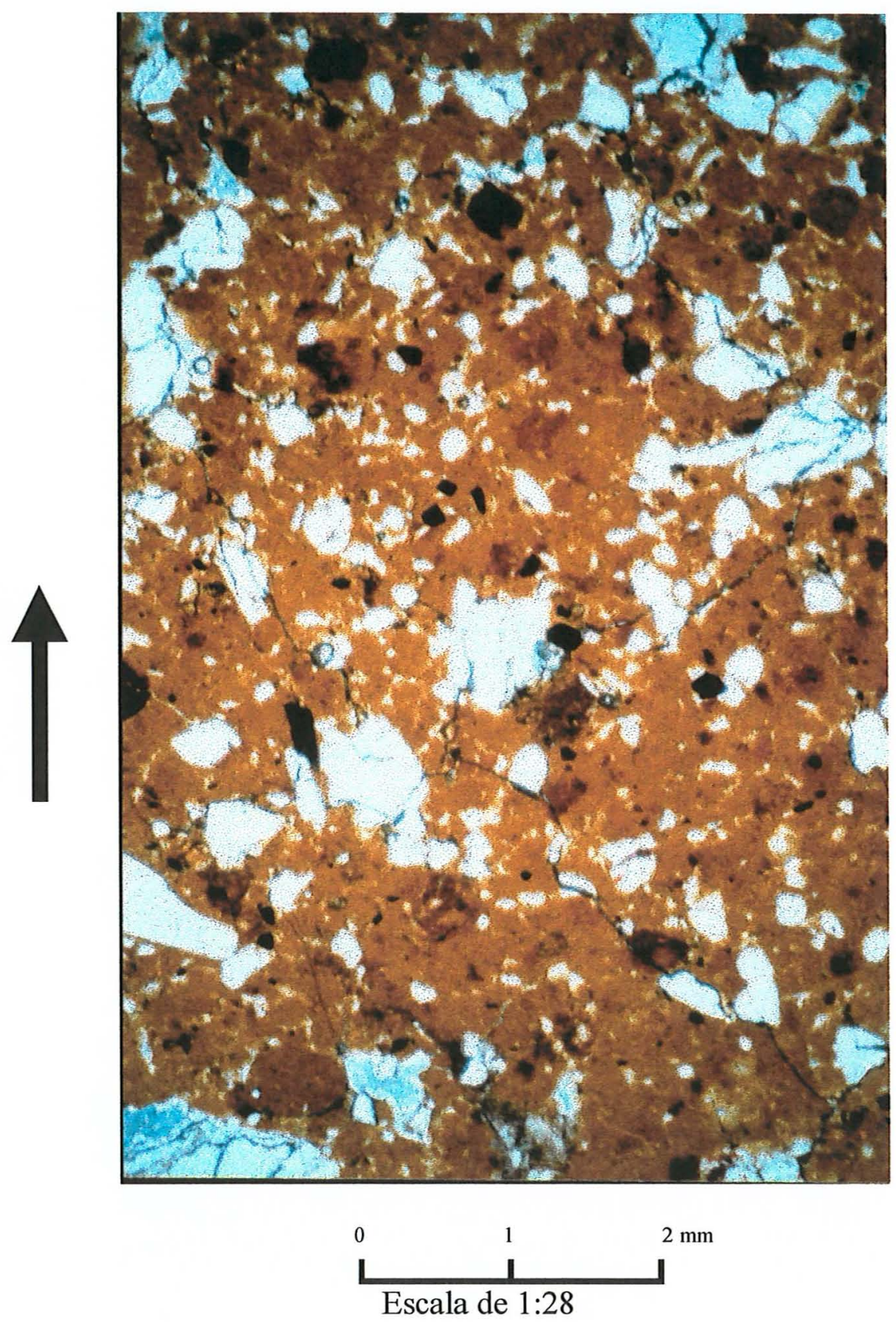

Figura 24. Fotomicrografia do horizonte $\mathrm{Bw}$ de P3, mostrando adensamento do plasma em Latossolo Vermelho Amarelo Húmico caulinítico-gibbsítico. Aumento de $28 \mathrm{x}$ 
A partir de 4,0m de profundidade o material de P3 apresenta atributos que se assemelham aos encontrados para a cobertura pedológica do sopé da colina posterior (P4). O esquema de formação do regolito de P3 é dado a seguir.

a)

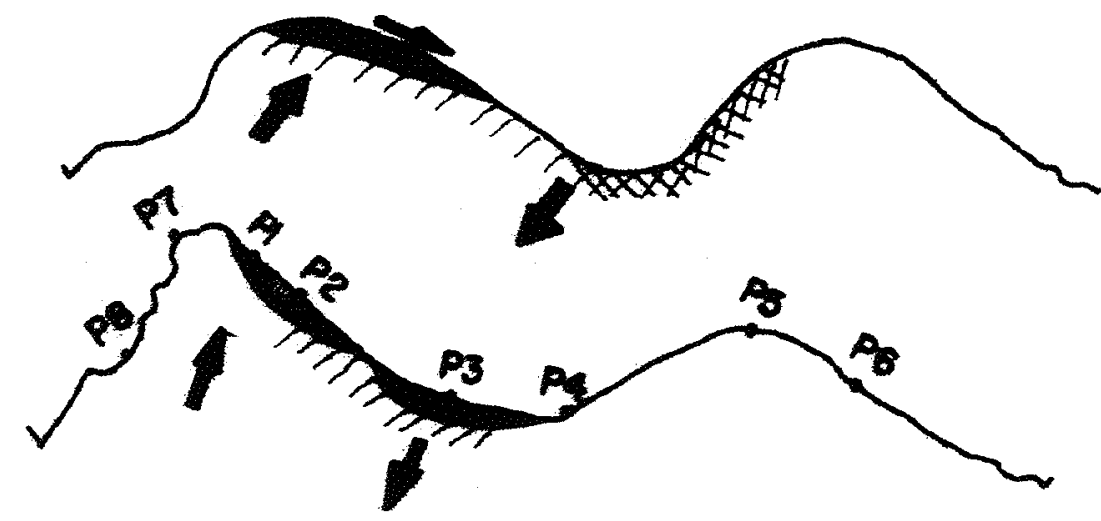

Figura 25 -Esquema simplificado do transporte a curta distância de regolito, na encosta SW do SI, a partir do Mioceno Médio. a)movimento de massa gerado pelo basculamento de blocos provoca transporte e b) deposição do material no sopé.

Partindo de P4 para sudoeste, a cobertura pedológica passa de latossólica para podzólica na meia encosta, onde a forma da superfície muda de côncava para convexa e os declives se acentuam. No topo desta colina, onde o relevo é suave ondulado, ocorrem novamente afloramentos de gnaisse félsico, desta vez associados a solo Podzólico Vermelho-Amarelo caulinítico pouco profundo (P5). O baixo grau de desenvolvimento dos solos do topo pode ser um indício de um novo basculamento de blocos, que carreou material encosta abaixo. Evidências deste basculamento tectônico são encontradas caminhando-se no sentido SW, onde ocorre, na posição de ombro, uma cobertura pedológica vermelha-escura com horizonte superficial estreito (P6) em área de relevo convexo. A partir deste ponto sucedem-se segmentos de encosta convexos e côncavos e os declives gradam de $15 \%$ para $48 \%$ sem que ocorra variação da cobertura pedológica. 
No terço final da encosta são encontrados matacões e calhaus à superficie e ao longo dos perfis. A diferente distribuição de areias entre P5 e P6 (Apêndice 5) pode estar relacionada a litologias diferentes.

O Sistema Morfopedológico II (Figura 6), cujas feições suavizadas são de gênese mais simples, é caracterizado por topos estreitos, de relevo suave ondulado, onde as declividades oscilam entre 2 e $6 \%$. Nestes topos, a cobertura pedológica é formada por latossolos muito profundos, de grande permeabilidade, com horizonte superficial escuro e rico em matéria orgânica, podendo ser espessos (húmicos) ou não. A presença de carvão ao longo da cobertura pedológica, tanto neste como nos demais segmentos das vertentes, é generalizada.

Quando ocorre o domínio de Latossolos Húmicos no topo, o mesmo se extende até a posição de ombro, onde os declives oscilam de 8 a $11 \%$.

Possivelmente esta cobertura se extendia por grandes áreas dentro da unidade geomorfológica denominada Planalto de Varginha pelo Radambrasil (1983). Esta unidade foi menos afetada por ações tectônicas e a dissecação da paisagem se deu a partir do Plioceno, levado a cabo pela erosão hídrica, causada por alterâncias climáticas quaternárias, cujos vestígios são os grandes incêndios que ocorreram entre 3 e 7 mil anos atrás ( Soubiés,1980; Sandford et al. , 1985; Turq et al., 1993; Lucas et al., 1993 Boulet et al., 1995) e que também provavelmente ocorreram na região deste estudo, produzindo uma significativa quantidade de fragmentos de carvão. Estes fragmentos são encontrados em profundidades de até $3,5 \mathrm{~m}$, revolvidos pela intensa ação da fauna do solo. Camargo et al. (1962) sugere que as feições do relevo destas áreas foram esculpidas pela erosão hídrica. Lichte (1990 e 1991) estudando as formas de relevo de "meia laranja" da região do Caraça-MG e que também ocorrem nas proximidades da área em foco, atribuiu a gênese das mesmas a ciclos de clima seco e úmido.

O domínio de latossolos húmicos no SMII, nos dias atuais, se retringe a poucos topos plano-conexos de pequenas dimensões, onde estão ilhados por latossolos vermelho-escuros e latossolos vermelhos-amarelos. A erosão hídrica, sucedente contemporânea dos incêndios florestais, proporcionou a dissecação da paisagem e o conseqüente carreamento da maior parte desta cobertura através da rede de drenagem 
que se instalou à partir do Plioceno. A Figura 26 ilustra a formação destes topos com cobertura pedológica húmica, que correspondem a vestígios da Superficie Sul Americana.

a)
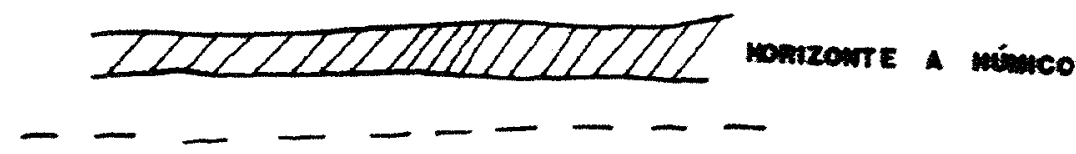

b)
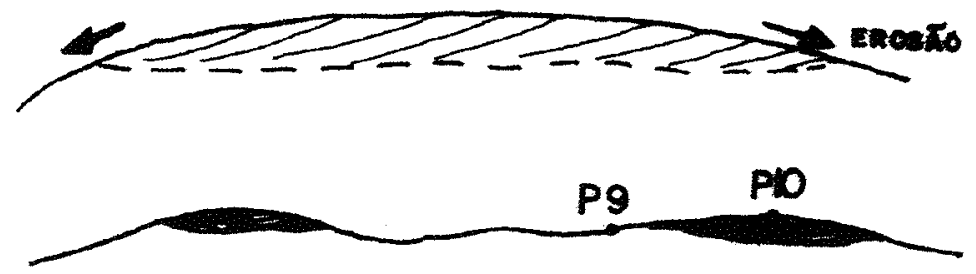

c)

Figura 26- Esquema simplificado da formação de topos com latossolo húmico no SMII, a partir do Plioceno. a) Superfície terciária; b) dissecação por erosão (predomínio); c) conformação atual.

Foram descritos 2 perfis de solo no topo ( $\mathrm{P9}$ e $\mathrm{P} 10$ ) até a profundidade de $3 \mathrm{~m}$, sendo P9 descrito em Latossolo Vermelho-Escuro e P10 descrito em Latossolo Húmico. Com exceção da espessura do horizonte superficial, os demais atributos morfológicos, químicos, fisicos, micromorfológicos e mineralógicos destes materiais são semelhantes.

As cores são iguais, tanto na superfície como em subsuperficie (Apêndice 1). Os teores de $\mathrm{Fe}, \mathrm{Ti}, \mathrm{Zr}$ e a relação $\mathrm{Ti} / \mathrm{Zr}$ (Apêndice 4 e Figura 27) são os mesmos para o horizonte escurecido e para o horizonte oxídico. A organização micromorfológica é a mesma e a mineralogia das argilas em todo o solum, em ambos os perfis, é cauliníticogibissítica. Os dois perfis (P9 e P10) também possuem os mesmos teores de areia, argila e a distribuição de areias é semelhante (Figura 28). Comparando estes resultados em todas as profundidades amostradas (Apêndices 2 e 5), observa-se uma correspondência entre o segundo horizonte de P9 (A2) e o primeiro horizonte de P10 (A1). Pode-se, então, inferir 

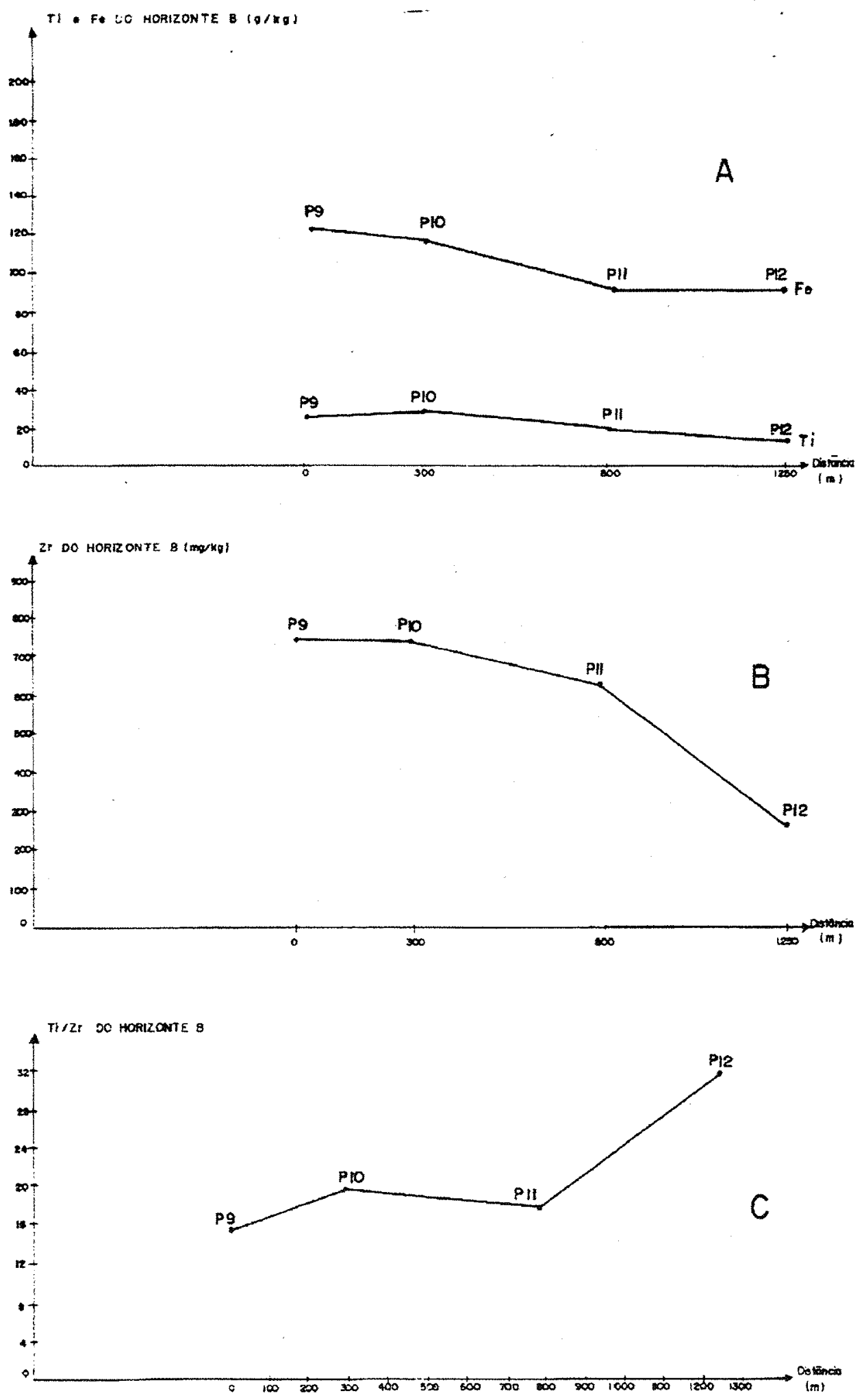

Figura 27. Teores de Ti e Fe (A); teores de $\mathrm{Zr}$ (B) e relação Ti/Zr dos solos de SMII 

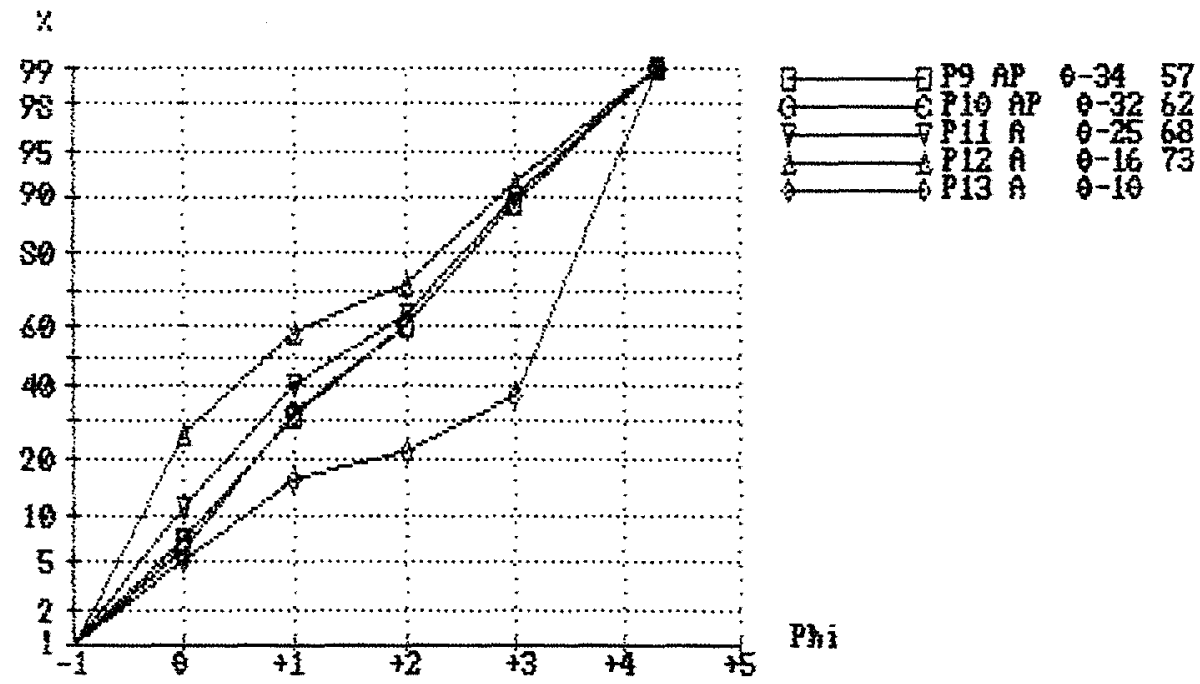

$\mathbf{P h} \mathbf{j}$
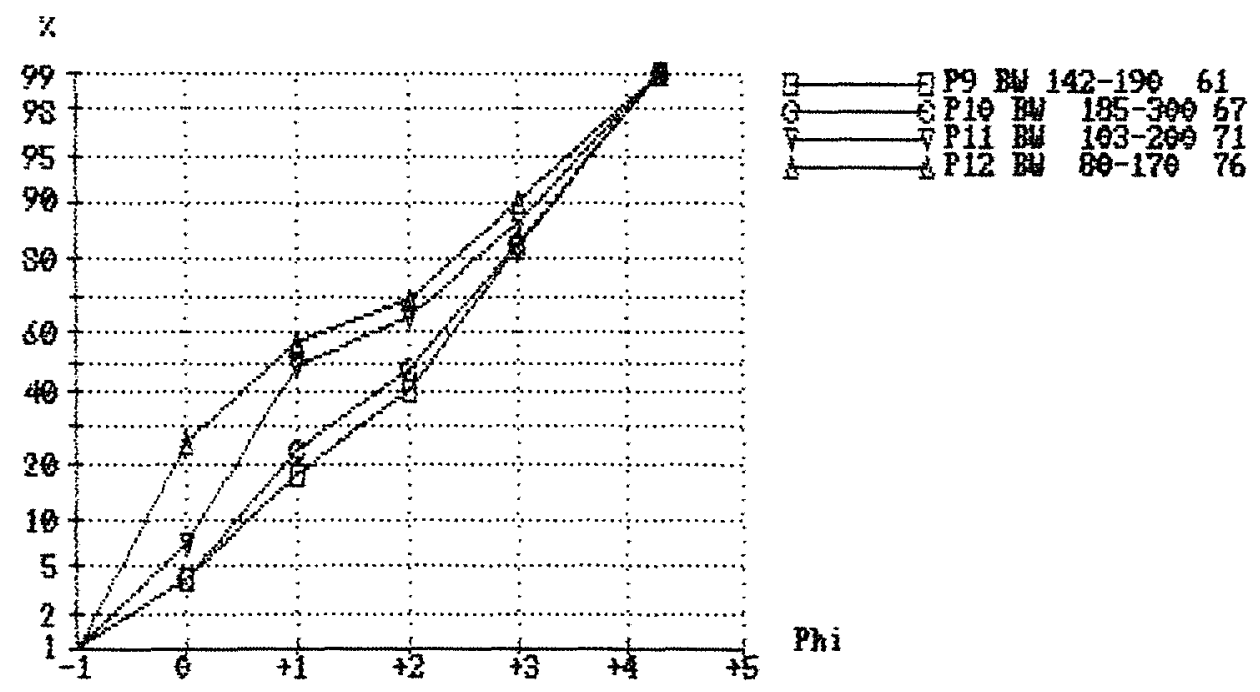

$\mathbf{P h i}$

Figura 28. Distribuição estatística das areias nos horizontes A e Bw dos solos que formam a cobertura de SMII. 


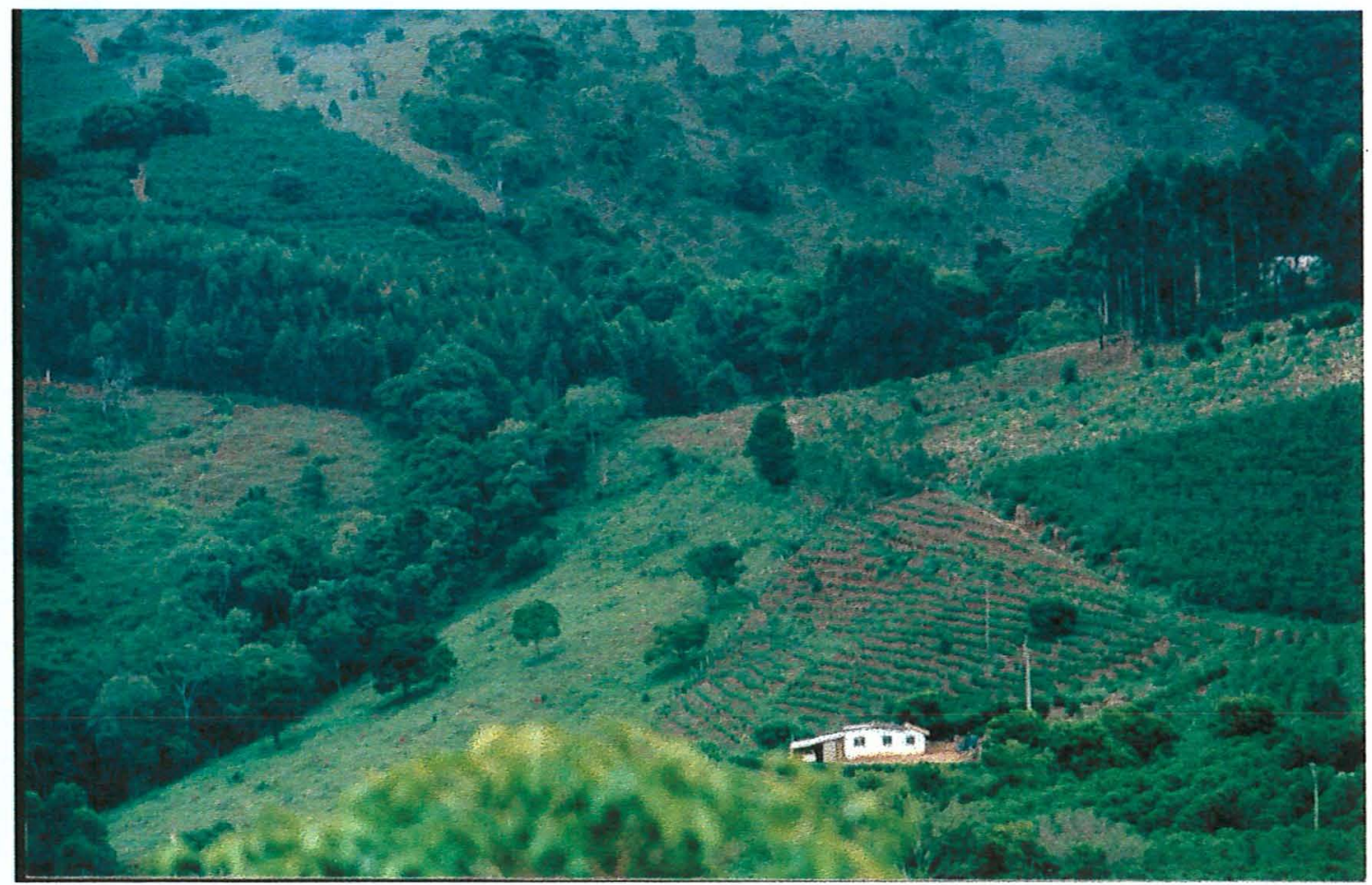

A)

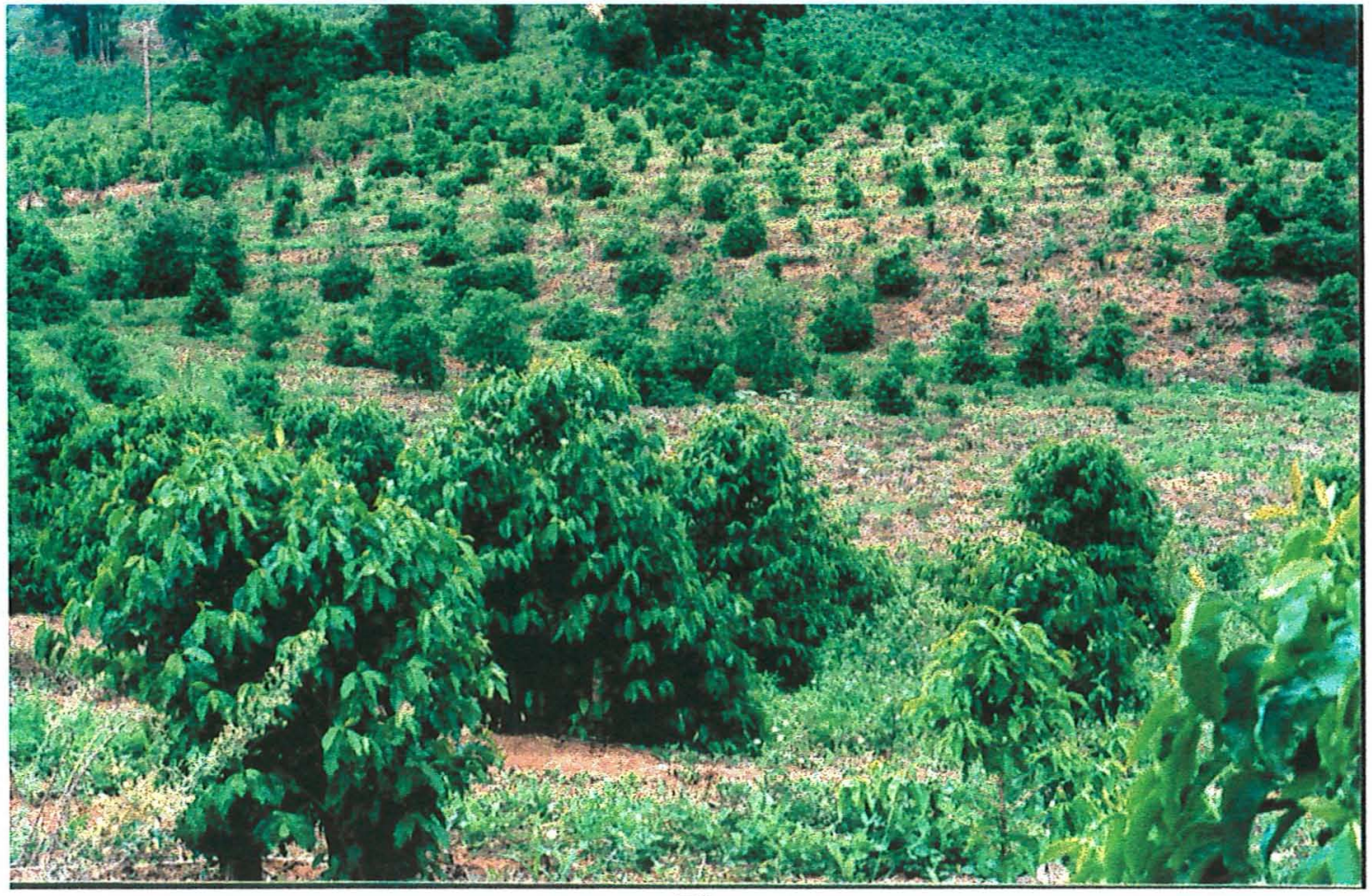

B)

Figura 29. A) Vista parcial do anfiteatro suspenso B) Depressão semi-fechada 
que $\mathrm{P}_{9}$ apresentava um horizonte superficial mais espesso e que foi erodido. Todas estas constatações corroboram a hipótese esquematizada na Figura 26.

As encostas do SMII são retilíneo-convexas e se iniciam em uma ruptura de declive entre ombro e a meia-encosta. Os declives variam de 19 a $23 \%$. Sua cobertura pedológica também é latossólica, mas o horizonte superficial é pouco espesso e apresenta cores mais claras. A transição entre a meia-encosta (onde foi descrito o perfil P11) e o sopé côncavo (onde foi descrito P12) é gradual e os declives oscilam entre 19 e 10\%. Deslizamentos de terra recentes também ocorrem nesta transição, possivelmente levados a cabo pela tectônica ressurgente residual, reativando a dissecação do relevo nas linhas de drenagem, que se instalam preferenciamente onde existem falhamentos e fraturamentos. As vertentes recuariam após remoção de material da meia-encosta com subseqüente deposição parcial no sopé.

A cobertura pedológica de todo o SMII, com exceção das várzeas, é latossólica, praticamente não havendo evidências (estrutura em blocos na parte superior do horizonte B) de seu adensamento e conseqüente formação do horizonte B textural encosta abaixo pela ação do fluxo lateral subsuperficial da água, de acordo com o modelo proposto por Moniz \& Buol (1982) para vertentes do estado de São Paulo e que foi corroborado por vários autores (Lepsch, 1975 e 1977; Vidal Torrado, 1989, 1994, 1995; Cooper, 1996; Castro, 1989). Apenas são encontrados indícios deste adensamento no terço inferior de algumas vertentes, onde ocorreram deslizamentos causados pelo rebaixamento do nível de base local.

A ausência de transição Bw-Bt encosta abaixo pode ser devida à grande permeabilidade do manto pedológico, que minimiza o fluxo lateral subsuperficial de maneira a não promover o adensamento do topo do horizonte Bw por ação mecânica de ciclos de umedecimento-secagem.

Apesar de toda a cobertura pedológica do SMII ser latossólica, diferenças em vários de seus atributos ao longo da encosta dão margens a novas especulações sobre a ação da erosão hídrica na dissecação da paisagem. A medida em que se avança abaixo, os teores de areia nos horizontes superficiais aumentam, os teores de argila nestes mesmos horizontes diminuem (Apêndice 2) e a distribuição de areias semelhantes em P11 e P12 se 
modifica grandemente em relação a P9 e P10 (Figura 28). Os teores de Fe, Ti e Zr diminuem e a relação Ti/Zr aumenta (Figura 27). A mineralogia da fração argila permanece caulinítico-gibbisítica (Apêndice 4).

O perfil descrito na meia-encosta (P11) apresenta seus horizontes mais argilosos próximos à superficie, enquanto que o perfil descrito no sopé (P12) apresenta três horizontes superficiais muito arenosos. Como a areia é predominantemmente formada por quartzo, por efeito de diluição os teores de Fe, Ti e $\mathrm{Zr}$ diminuem ao longo da encosta (Apêndice 4). Também são encontrados fragmentos arredondados e arestados de quartzo e gnaisse e decomposição tanto em P11 como em P12. Porém em P12 estes fragmentos são muito mais abundantes.

Estas constatações comprovam a atuação do defluvio superficial na encosta, carreando os horizontes superficiais das partes superiores da mesma e depositando preferencialmente as partículas mais grosseiras ao perder energia, ou seja, no sopé, que é menos declivoso.

As evidências encontradas no campo, no escritório e nos laboratórios embasam a construção de um modelo regional de evolução do relevo da região do estudo e apontam na direção da tectônica ressurgente e de alterâncias climáticas como fenômenos responsáveis pela adição de energia necessária para o esculpimento da paisagem. No SMI, onde ocorrem fraturas e falhamentos nos contatos entre litologias distintas, o maior "input" de energia provavelmente é dado pela tectônica ressurgente, responsável pelos movimentos de massa. No SMII onde a litologia é formada por rochas de apenas um Complexo Geológico e o relevo é suavizado, a principal fonte de energia para a dissecação da paisagem pela erosão hídrica são as alternâncias climáticas.

\subsection{SOLOS}

\subsubsection{Mapa Semi-Detalhado}

A seguir é apresentada a legenda com as doze unidades de mapeamento encontradas nas área estudada (Figura 30). 

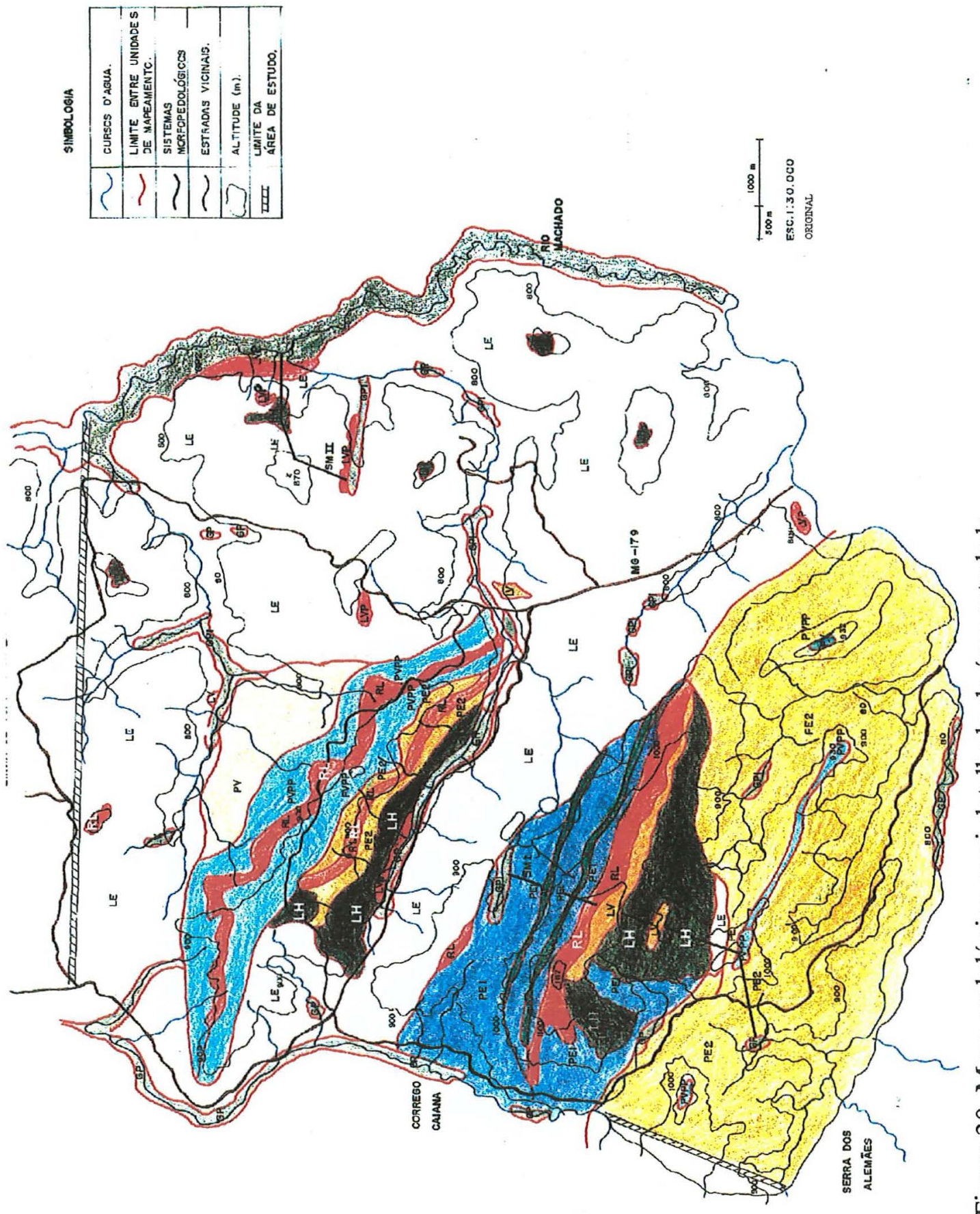

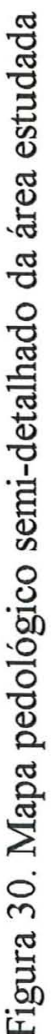




\section{LEGENDA}

Cor Símbolo

Unidade de Mapeamento

Área

ha $\%$

LE Latossolo Vermelho-Escuro, distrófico, A proeminente ou moderado, textura muito argilosa + Latossolo Vermelho Amarelo, distrófico, A moderado, textura muito argilosa.

$3212,42 \quad 55,83$

LH Latossolo Vermelho Amarelo Húmico, distrófico e álico, A húmico, textura muito argilosa + Latossolo Vermelho-Escuro Húmico, distrófico, A húmico, textura muito argilosa.

$268,00 \quad 4,66$

LV Latossolo Vermelho Amarelo, distrófico, A proeminente, textura muito argilosa.

42,20

LVP Latossolo Vermelho Amarelo Podzólico, distrófico, A moderado, textura argilosa/ muito argilosa.

$34,36 \quad 0,59$

Podzólico Vermelho-Escuro, eutrófico, tb, A chernozêmico,

PE1 textura argilosa/ muito argilosa + Podzólico Vermelho-Escuro, eutrófico, tb A chernozêmico, textura média/argilosa, fase pouco profundo.

PE2 Podzólico Vermelho Escuro, distrófico, tb, A moderado, textura argilosa/ muito argilosa.

PEpp Podzólico Vermelho-Escuro, eutrófico, tb , A moderado, textura média/ argilosa, fase pouco profundo + Podzólico VermelhoEscuro, eutrófico, tb, A moderado, textura média.

$67,90 \quad 1,18$

PV Podzólico Vermelho Amarelo, eutrófico, tb, A chernozêmico, textura argilosa/ muito argilosa.

$115,36 \quad 2,00$

PVpp Podzólico Vermelho Amarelo, distrófico, tb, A moderado, textura argilosa/ muito argilosa, fase pouco profundo.

RL Litossolo, distrófico e eutrófico, tb, A moderado, textura média e arenosa + Afloramentos de rocha

$162,00 \quad 2,81$

GP1 Gleissolos indiscriminados

$204,50 \quad 3,55$

GP2

Gleissolos indiscriminados + Solos Aluviais indiscriminados

$226,63 \quad 3,94$

Total

$5750,00 \quad 100$

Os Litossolos são originados do gnaisse leucocrático, que também é um dos materiais fonte dos podzólicos pouco profundos e, em pequena proporção, dos horizontes Ap que se situam encosta abaixo. Os podzólicos vermelho-escuros 
provavelmente são formados a partir da meteorização de granulitos do Complexo Guaxupé, apresentando teores de Fe e de Ti semelhantes aos encontrados nestas rochas. Os latossolos são formados por materiais retrabalhados (Camargo et al., 1962; Radambrasil, 1983), transportados a curta distância e revolvidos intensamente pela ação da fauna do solo. Os gleissolos e os solos aluviais originam-se respectivamente de colúvios e alúvios hidromorfizados e de depósitos aluviais.

Os latossolos dominam amplamente as colinas suavizadas, onde está instalado o SMII. Ocupam $95 \%$ da área destas colinas ( 3212,42 ha ). Nas áreas de topografia montanhosa, representadas pelo SMI, os podzólicos são os solos mais comumente encontrados, ocupando 1600 ha (84\%).

\subsubsection{Morfologia dos solos (pedografia)}

Os resultados das descrições morfológicas (de campo, com lupa e micromorfológica) e das análises de laboratório feitas em amostras coletadas nos diferentes perfis estudados (Apêndices 1, 2, 3 e 4) embasam, juntamente com a análise estrutural, a discussão das principais hipóteses que nortearam os processos pedogenéticos atuantes em cada sistema morfopedológico, e está inserida no quadro geral da dinâmica da paisagem regional.

\subsubsection{Sistema Morfopedológico I ( SMI)}

Esta transeção possui 3.000 metros de extensão, iniciando e terminado em um curso d'água. Suas feições geomorfológicas e sua sequência de solos contrastam com a maioria dos modelos de paisagem estudados em escala local no centro-sul do Brasil. Características próprias como front escarpado com sopé trapezoidal (linha de falha e escarpa de linha de falha) e reverso ondulado com espessa cobertura latossólica húmica, além de solos em diferentes estágios de desenvolvimento, ocorrendo de maneira intercalada, compõe um quadro representativo na paisagem regional. Tais características tornam este sistema morfopedológico intrigante e peculiar aos olhos da pedogênese. 
Em seus segmentos de topo são encontrados solos pouco desenvolvidos, classificados como Litossolo distrófico e eutrófico, tb, de textura média e arenosa (a $1160 \mathrm{~m}$ de altitude) e Podzólico Vermelho Amarelo distrófico, tb, de textura argilosa/ muito argilosa fase pouco profundo (a $1080 \mathrm{~m}$ de altitude).

O Litossolo apresenta horizonte A com cores escuras, elevado teor de matéria orgânica ( em torno de $45 \mathrm{gkg}^{-1}$ ) e espessura inferior a $10 \mathrm{~cm}$. Sua estrutura é composta por pequenos grânulos arredondados e fortes e médios blocos subangulares moderados. A soma de bases e saturação por bases estão entre as maiores dentre os solos estudados. Seus teores de areia grossa são bem elevados, com presença de alguns minerais primários facilmente intemperizáveis como os feldspatos, o que pode explicar seu alto valor S.O Podzólico Vermelho Amarelo pouco profundo tem de 70 a $80 \mathrm{~cm}$ de profundidade e horizonte A escuro, rico em matéria orgânica e com soma de bases trocáveis média de $2,5 \mathrm{cmol}_{\mathrm{c}} \mathrm{kg}^{-1}$ de terra, e espessura em torno de $10 \mathrm{~cm}$ (Apêndices 1, 2 e 3).

Seu horizonte $\mathrm{Bt}$ possui estrutura em blocos e prismas moderados a fortes com tamanho variando entre 2 e $7 \mathrm{~cm}$ e cerosidade moderada e comum. Por vezes está assentado diretamente sobre a rocha (gnaisse leucocrático). Fragmentos de carvão e matacões, calhaus e cascalhos de gnaisse são encontrados em todo o perfil. A pequena atividade da fauna do solo contrasta com a intensa atividade de cupins e formigas observada nos demais perfís. Minerais primários como quartzo, feldspatos e mica e ilmenita estão presentes na fração silte do horizonte Bt destes solos. A mineralogia de sua fração argila é caulinítica (Apêndice 4).

A presença de controle estrutural é evidente, pois os bolders encontrados são unicamente de gnaisse leucocrático. Os processos que denudaram estes blocos de rocha, expondo-os à superficie, podem ser elucidados através da análise estrutural e de atributos mineralógicos, químicos, físicos e morfológicos dos solos.

Observando-se a Figura 5, verifica-se que, descendo a encosta no sentido sudoeste a partir do topo mais alto, o horizonte $\mathrm{A}$ e o regolito vão se espessando cada vez mais, até as proximidades do próximo controle estrutural, onde têm sua espessura diminuida radicalmente. O solo muda abruptamente de Litossolo para Latossolo Vermelho Amarelo (perfis extra 64 e P1) no terço superior deste segmentos de encosta, 
passando para Latossolo Húmico no terço médio (P2) e retornando para Latossolo Vermelho Amarelo no terço final, próximo a outro controle estrutural. Continuando a descer a encosta o Latossolo Húmico (P3) volta a ocorrer, transicionando para Latossolo Vermelho Escuro (P4) no sopé da colina adjacente, após a depressão semi-fechada (Figura $29 \mathrm{~B}$ ).

Duas hipóteses são aventadas para explicar a presença de blocos de rocha desnudos no topo e o espessamento do horizonte superficial encosta abaixo. A primeira delas é a ação da tectônica ressurgente, causando basculamento de blocos (Mioceno Médio) que ativaram os movimentos de massa, responsáveis pela redistribuição material latosólico pela vertente, a partir do topo. Este fenômeno já foi esquematizado na Figura 27.

A outra hipótese formulada para explicar o espessamento do horizonte superficial encosta abaixo é a atividade da fauna do solo, remontando intensamente material latossólico. Horizontes sômbricos e biopedotúbulos preenchidos com agregados de origem biológica atestam o remonte. Ela também não explica sozinha este espessamento, pois existem solos na área com intensa atividade biológica e horizonte $\mathrm{A}$ de $20 \mathrm{~cm}$. Estas duas hipóteses serão discutidas em conjunto com outras no capítulo referente a gênese do horizonte $\mathrm{A}$ húmico.

\section{Perfis Extra 64 e P1 (meia-encosta convexa)}

Os perfis lotados no segmento superior da encosta (Extra 64 e P1) foram classificados como Latossolo Vermelho Amarelo distrófico de textura muito argilosa, sendo que o perfil Extra 64 apresenta horizonte A moderado com $40 \mathrm{~cm}$ de espessura e no perfil P1 o horizonte A é proeminente com $105 \mathrm{~cm}$ de espessura. Ambos apresentam cores escuras nos primeiros centímetros (valor e croma iguais a 3) que vai clareando, à medida em que se ganha profundidade. Os teores de matéria orgânica são medianos e os teores de argila são cerca de $20 \%$ menores que os do horizonte B. Possui $76 \mathrm{~g} \mathrm{~kg}^{-1}$ de Fe, $4 \mathrm{~g} \mathrm{~kg}^{-1}$ de Ti, $562 \mathrm{mg} \mathrm{kg}^{-1}$ de $\mathrm{Zr}$ e relação de Ti/Zr de 7,19 (Apêndice 4).

A estrutura do horizonte $\mathrm{A}$ de ambos é mista, formada por grânulos muito pequenos e fortes e por blocos subangulares moderados a fracos e médios, que se 
desfazem em grânulos fortes e muito pequenos. A análise de amostras indeformadas com auxilio da lupa confirmou a descrição da estrutura no campo. Microagregados menores que $1 \mathrm{~mm}$ de diâmetro com duas tonalidades de cores brunadas, arredondados e poliédricos são formados pela coalescência de outros agregados arredondados ainda menores e partículas de quartzo e de carvão. Os microagregados de $1 \mathrm{~mm}$ de diâmetro se unem a partículas de areia (quartzo poliédrico) e a fragmentos de carvão para formar agregados maiores, poliédricos ou ovalados. A atividade biológica é intensa, marcada pela presença de inúmeros canais de origem biológica com até $6 \mathrm{~cm}$ de diâmetro e pela

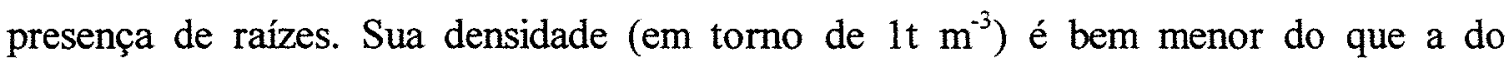
horizonte $\mathrm{Bw}$, pois a porosidade chega a ocupar $60 \%$ do volume deste horizonte, notadamente nas crotovinas e biopedotúbulos preenchidos. O desenho destes agregados está apresentado na Figura 31.

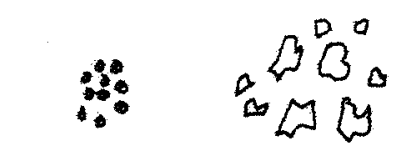

Microagre

gados

menores

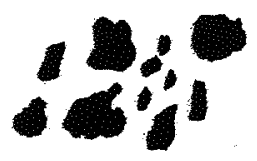

Fragmentos de carvão

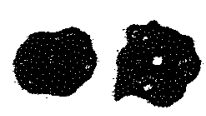

Microagregados menores que $1 \mathrm{~mm}$
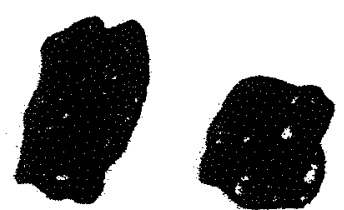

Agregados maiores que $1 \mathrm{~mm}$, poliédricos (blocos), arredondados (grânulos) que $0,1 \mathrm{~mm}$

Figura 31- Representação esquemática de fragmentos de carvão, de partículas de quartzo do tamanho areia e de diferentes tipos de agregados que ocorrem nos latossolos

A análise micromorfológica deste horizonte corrobora as descrições morfológicas feitas anteriormente. A pedalidade é fortemente desenvolvida; a trama é grânica-granóidica e o esqueleto é formado por fragmentos de quartzo (8\%) e de carvão (5\%) de tamanhos e formas variados (Figura 32). Microagregados arredondados menores que $0,1 \mathrm{~mm}$, formados unicamente de plasma ocorrem principalmente coalescidos a outros, bem como a partículas de quartzo e de carvão, formando microagregados menores que $1 \mathrm{~mm}$, arredondados (a maioria) e poliédricos. Estes por sua vez se unem 


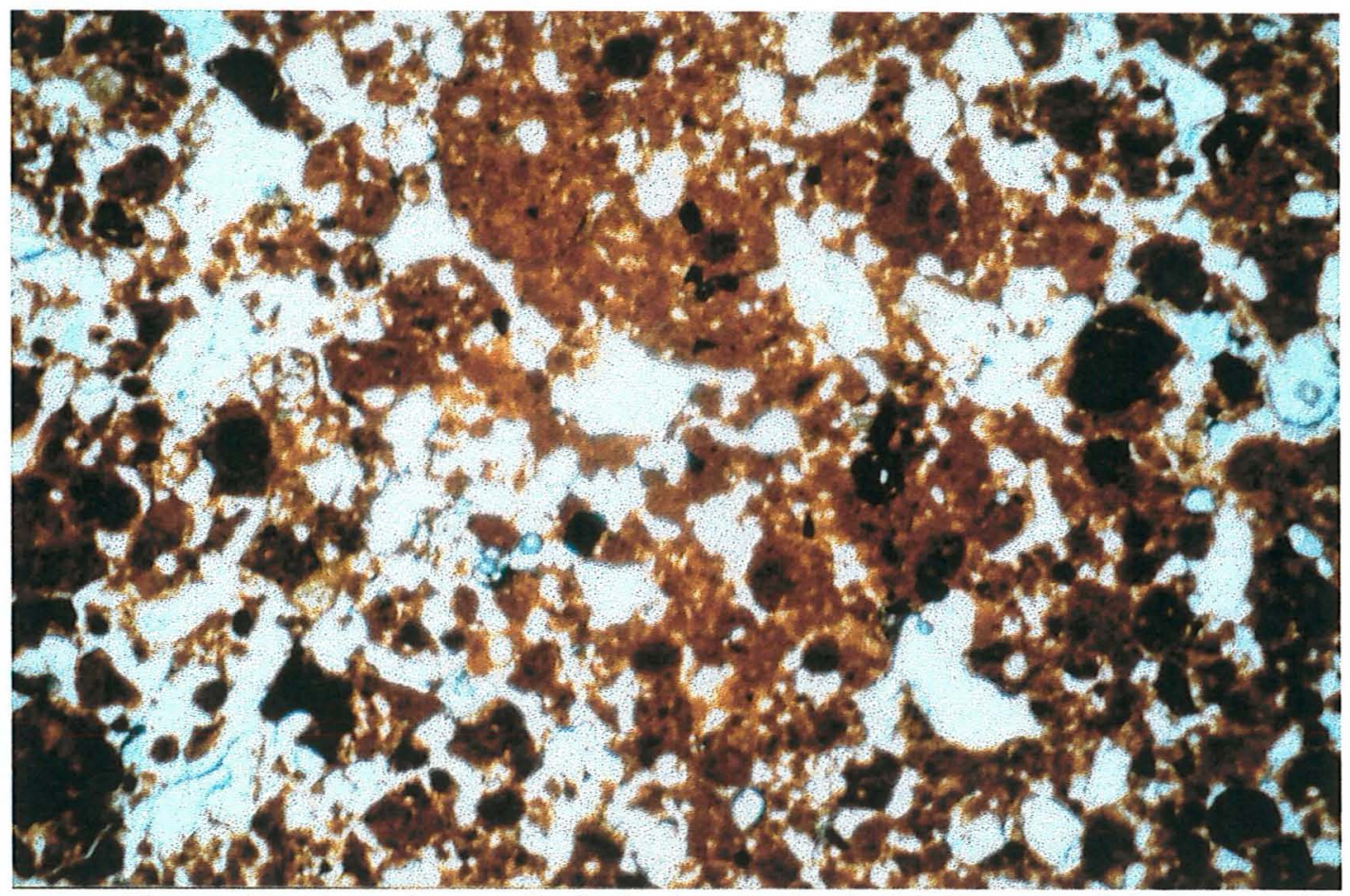

Figura 32. Fotomicrografia do horizonte Ap de P1. Trama grânica- granoídica

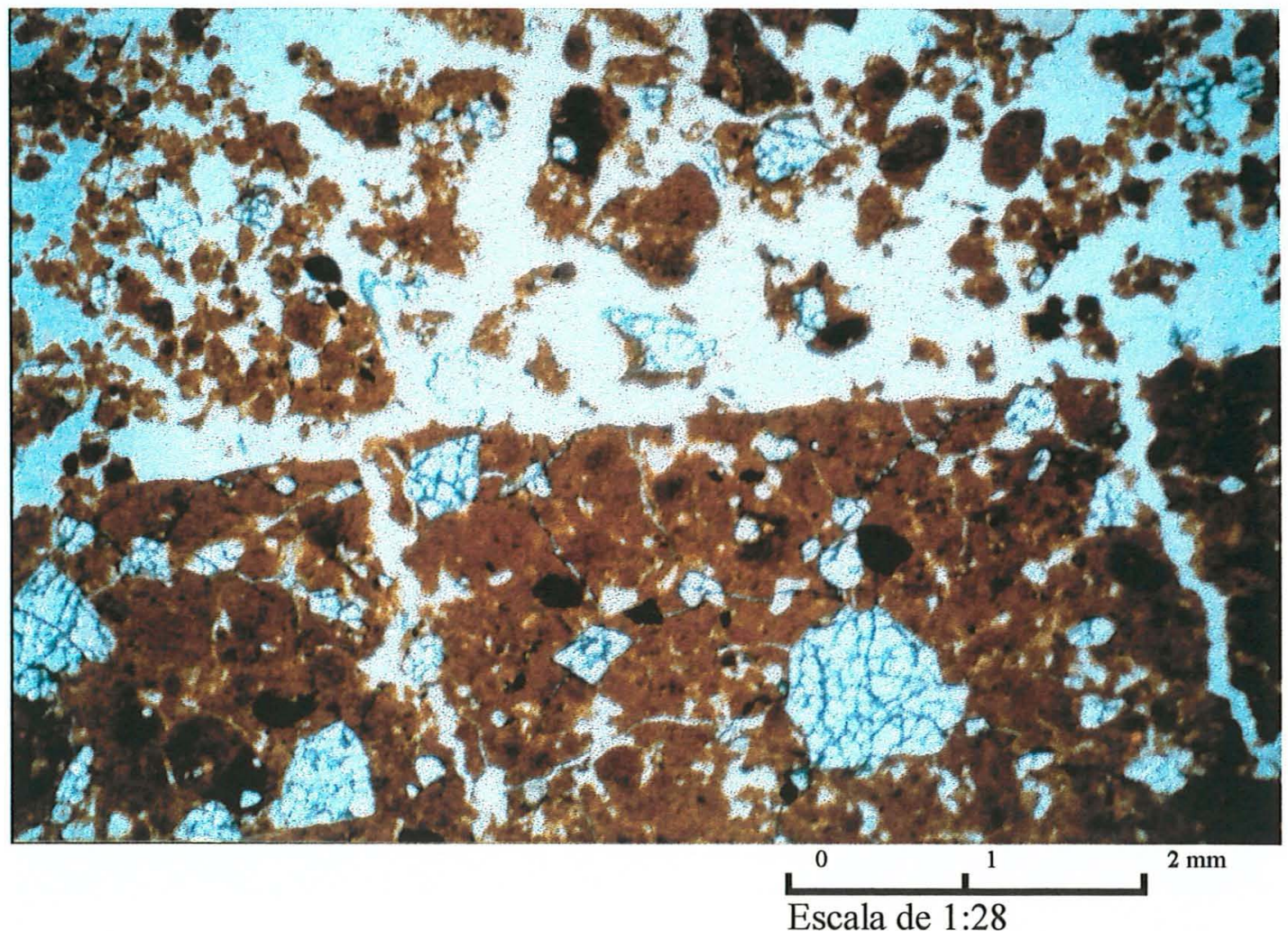

Figura 33. Fotomicrografia do horizonte A2 de P1. Adensamento do plasma próximo as paredes dos biopedotubulos 
para formar agregados maiores que $1 \mathrm{~mm}$, poliédricos e arredondados. A presença de esqueleto triado (partículas de quartzo e carvão, selecionadas e menores que as encontradas fora dos microagregados) é corriqueira nos menores que $1 \mathrm{~mm}$. Esta descrição corrobora trabalhos de Miklós ( 1993, 1996), para o qual a forma externa esférica ou oval, subestrutura em microagregados esféricos ou ovais, presença de micropartículas de carvão ovaladas e esqueleto triado são evidências de origem biológica dos microagregados do solo. Poros, canais e cavidades de origem biológica com largura de $1 \mathrm{~cm}$ e comprimento variado, preenchidos predominantemente por microagregados esféricos menores que $1 \mathrm{~mm}$ é outra constatação da ação da fauna do solo.

Próximo às paredes dos biopedotúbulos o plasma se adensa e a trama se torna granóidica-porfirítica (Figura 33), mas ainda consegue-se perceber a forma dos microagregados. Este adensamento pode ser atribuido ao deslocamento de material plásmico durante a construção destes biopedotúbulos.

A porosidade total varia de 50 a $60 \%$ e muitos dos poros são fissurais (Figura 33 ), pois suas paredes são concordantes. Estes poros apresentam até $0,1 \mathrm{~mm}$ de largura e podem ser originados da contração e expansão do plasma, apesar da mineralogia caulinítico-gibbsítica das argilas deste horizonte. Beaudou (1972) e Stoops \& Buol (1985) relacionam a porosidade fissural como uma das etapas que levam a formação de microagregados por estruturação. Os poros fissurais e a fissuras apresentam nítida orientação SE-NW, o que pode ser interpretado como vestígios da ação tectônica ressurgente.

Estes horizontes são ácidos, apresentam média CTC (dado pela matéria orgânica mediana) e baixa soma de bases e considerável teor de alumínio trocável. As ligações humus-argila ( Stevenson,1982; Lepsch \& Buol, 1986, Santos et al., 1989; Melo, 1994) podem ser uma das causas do escurecimento destes microagregados e da coalescência entre os mesmos, formando outros maiores. quartzo, feldspato e mica dominam a fração silte (Apêndice 4 ). Seus menores teores de argila em relação aos demais horizontes do perfil pode ser devido deposição de material arenoso carreado a montante e/ ou transporte de material fino pelos cupins e formigas para camadas inferiores 
(Eschenbrenner, 1996) e/ ou concentração residual de partículas grosseiras na superfície, pela ação de enxurrada. Destas três hipóteses, a última geralmente só ocorre em ambiente desprovido de cobertura vegetal densa. Mas a ação da fauna do solo é antiga e praticamente ininterrupta e a deposição de material arenoso a partir de montante pode ocorrer por movimentos de massa. Estas observações convergem para o modelo proposto de evolução conjunta de paisagem e dos solos, a partir da tectônica, da erosão hídrica e da ação contínua da fauna do solo nas partes mais preservadas da paisagem.

$\mathrm{O}$ horizonte $\mathrm{B}$ latossólico $(\mathrm{Bw})$ destes perfis possui cores amarelo-avermelhadas e espessura superior a $2 \mathrm{~m}$. Seus teores de argila são sempre superiores a $600 \mathrm{~g} \mathrm{~kg}^{-1}$ e sua densidade oscila em torno de $1,20 \mathrm{t} \mathrm{m}^{3}$ (20\% maior que a Ds do horizonte A). Quimicamente é caracterizado pela CTC menor que $6 \mathrm{cmol}_{\mathrm{c}} \mathrm{kg}^{-1}$, valor $\mathrm{S}$ em torno de 2 $\mathrm{cmol}_{\mathrm{c}} \mathrm{kg}^{-1}, \mathrm{pH}$ ácido e baixos teores de alumínio trocável (Apêndice 3). A fração silte é constituída por feldspatos e mica enquanto que a fração argila é caulinítico-gibbsítica (Apêndice 4). Seus teores de $\mathrm{Fe}$, de $\mathrm{Ti}$, de $\mathrm{Zr}$ e a relação $\mathrm{Ti} / \mathrm{Zr}$ se assemelham aos encontrados para o horizonte A (Apêndice 4). Fragmentos de carvão são comuns neste horizonte.

A estrutura do horizonte $\mathrm{Bw}$ é composta de blocos e primas, moderados, médios a grandes, que se desfazem em grânulos fortes e muito pequenos. A atividade biológica é intensa, observando-se biopedotúbulos preenchidos, com diâmetro entre 0,5 e $4,0 \mathrm{~cm}$. Através da análise morfológica de amostras indeformadas foram identificados microagregados poliédricos amarelados menores que $1 \mathrm{~mm}$, que geralmente ocorrem coalescidos, formando agregados poliédricos maiores. Esparsos microagregados ovalados, brunados e com esqueleto interno triado constituído por quartzo e carvão (de provável origem zoogenética) são encontrados fora dos biopedotúbulos, predominando dentro dos canais e cavidades construídos pela ação da fauna do solo. A porosidade é grande, notadamente nos biopedotúbulos. Mesmo nesta escala se observam fissuras nos agregados maiores, que vão se partindo em microagregados.

A descrição de lâminas delgadas destes horizontes confirma as observações feitas no campo e nas amostras indeformadas. A pedalidade é fortemente desenvolvida e a trama é predominantemente grânica-granóidica, sendo porfirítica em alguns locais. Mas, 
mesmo nestes locais percebe-se a forma dos microagregados que estão adensados. O esqueleto é composto por fragmentos de quartzo e carvão arestados e ovalados e de tamanho variado, que ocupam respectivamente 10 a $4 \%$ dos campos observados. Os poros ocupam cerca de $35 \%$ do campo observado, sendo constituídos por canais e cavidades de origem biológica e fissuras. As últimas apresentam orientação preferencial SE-NW, assim como a encontrada em todos os horizontes destes perfis (Figura 34 ).

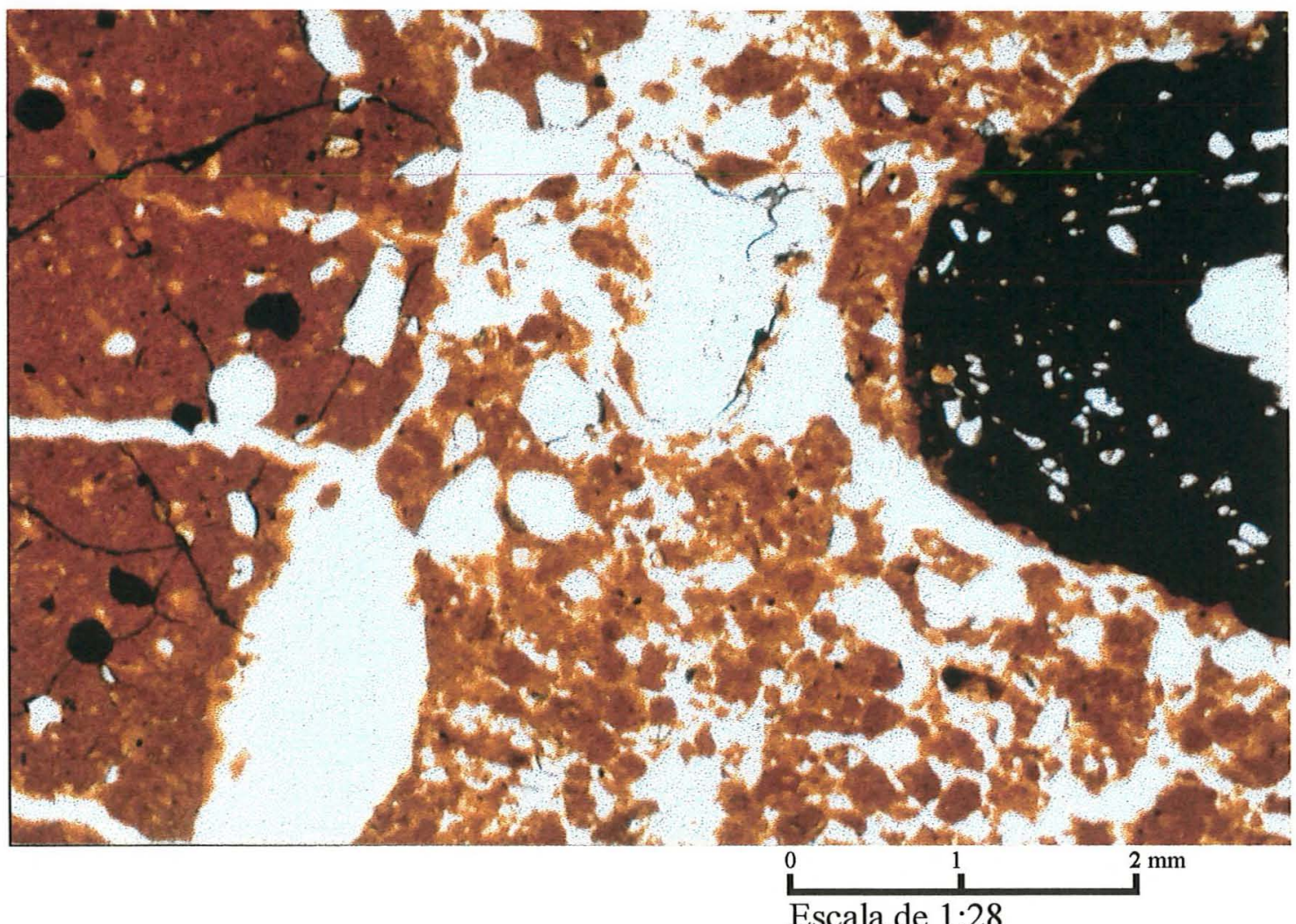

Figura 34. Fotomicrografia do horizonte Bw2 de extra 64. Trama grânicagranoidica e porfiritica.

As principais diferenças encontradas neste perfil, em relação a estrutura, são o menor número de microagregados brunados e arredondados de origem biológica em $\mathrm{Bw}$, plasma mais adensado (menor porosidade) em Bw, maior teor de fragmentos em carvão no horizonte A e a trama, que chega a ser profirítica em algumas partes de Bw.

A origem dos microagregados do horizonte A foi atribuída a ação da mesofauna, a microestruturação e a complexação, em conjunto ou isoladamente. Porém, em Bw, 
nem todos os microagregados apresentam pedogênese relacionada a zoogênese, a complexação e a microestruturação. Ferreira (1988) relaciona latossolos com estrutura em blocos a mineralogia caulunítica da fração argila e latossolos com estrutura granular a mineralogia gibbsítica das argilas. Este mesmo autor coloca que os óxidos de ferro influenciam discretamente na manifestação das propriedades fisicas de latossolos. A estrutura de $\mathrm{Bw}$ (blocos médios formados por microagregados coalescidos) corrobora as observações deste autor, mas a participação efetiva dos óxidos de ferro na gênese de microagregados não se enquadra na afirmativa do mesmo quanto a relação entre ferro e propriedades físicas dos latossolos.

A mineralogia caulinítico-gibbsítica (com predomínio de caulinita), os teores de ferro $\left(80 \mathrm{~g} \mathrm{~kg}^{-1}\right)$ e a descoloração de microagregados (passando de amarelo avermelhado para amarelo), são fatores a serem relevados para consideração da origem geoquímica de parte destes microagregados. A presença de alta umidade e de matéria orgânica favoreceria a goethitização de parte das hematitas (Resende, 1980; Resende et al., 1988; Curi, 1983; Curi \& Franzmeier, 1984). A desferrificação parcial resultante da transformação hematita-goethita contribuiria para a individualização dos micronódulos, conforme modelo proposto por Chauvel (1978), citado por Stoops (1983). Assim, teríamos neste horizonte microagregados zoogenéticos, microestruturais, geoquímicos $\mathrm{e}$ complexos, sendo todos estes tipos de pedogênese descritos por Muller (1977 e 1981). Vidal Torrado (1994) também atribuiu vários tipos de gênese aos microagregados de latossolos de Piracicaba - SP.

Por outro lado, o adensamento do plasma identificado no horizonte $\mathrm{Bw}$ vai de encontro ao anteriormente exposto e deixa margens a seguinte indagação: estão os microagregados sendo formados ou estão sendo coalecidos, causando o adensamento do plasma? As análises morfológicas, micromorfológicas e químicas (minerais índices) e mineralógicas, em conjunto com as evidências de tectônica ressurgente, apontam na direção de um grande dinamismo na paisagem, marcado por ciclos interligados de microagregação e adensamento. A ação da fauna do solo e a geoquímica do ferro levariam à formação de microagregados, enquanto que os movimentos de massa levariam ao adensamento do plasma, com posterior retomada da microagregação. A 
microestruturação teria uma relação de causa e efeito com os movimentos de massa e com a microagregação.

\section{Perfil 2 (meia-encosta côncava)}

$\mathrm{O}$ perfil descrito no terço médio deste segmento de encosta $(\mathrm{P} 2)$ corresponde a um Latossolo Vermelho Amarelo Húmico textura muito argilosa, com um horizonte $\mathrm{A}$ húmico de $200 \mathrm{~cm}$ de espessura. O teor de matéria orgânica é superior a $20 \mathrm{~g} \mathrm{~kg}^{-1} \mathrm{em}$ todo o horizonte $\mathrm{A}$, o que acarreta em melanização (croma igual a 2 e valor igual a 3 ).

O horizonte húmico apresenta caráter álico, com teores de alumínio trocável superior a $1,8 \mathrm{cmol}_{\mathrm{c}} \mathrm{kg}^{-1}$ e valor $\mathrm{S}$ inferior a $1,5 \mathrm{cmol}_{\mathrm{c}} \mathrm{kg}^{-1}$. Sua CTC é superior a 10,8 $\mathrm{cmol}_{\mathrm{c}} \mathrm{kg}^{-1}$, devido principalmente à contribuição da matéria orgânica, que complexa o $\mathrm{Al}$ trocável, minimizando sua saída do sistema (Stevenson,1982; Melo, 1994). O pH é sempre inferior a 4,8 e o teor de fósforo disponível é baixo. A mineralogia da fração argila é caulinítico-gibbisítica, com predomínio da caulinita. $\mathrm{Na}$ fração silte ocorrem quartzo, feldspatos e mica. A fração areia fina predomina dentre as frações areia. $\mathrm{O}$ horizonte Ap é mais arenoso do que os demais. Esta maior quantidade de areia na superficie provavelmente é devida a ação da fauna do solo e a deposição de material arenoso a partir de montante, como discutido para P1 e Extra 64. Seus teores de ferro total, titânio total, zircônio total e relação Ti/ $\mathrm{Zr}$ são respectivamente $67 \mathrm{~g} \mathrm{~kg}^{-1} ; 4,2 \mathrm{~g} \mathrm{~kg}^{-1}$; $481 \mathrm{mg} \mathrm{kg}^{-1}$ e 8,77.

No campo sua estrutura foi classificada em maçica porosa "in situ" que se desfaz em muito forte, muito pequena e granular e em alguns blocos subangulares, moderados, pequenos e médios. A atividade da fauna do solo foi e é intensa, com muitos coprólitos presentes neste horizonte. A ação de cupins e formigas ao longo do perfil é marcante, construindo e preenchendo inúmeros canais e cavidades. Muitos fragmentos de carvão, de tamanho e forma variada, e esparsos fragmentos de gnaisse ferruginizado, são encontrados em A húmico. Em alguns locais deste horizonte observa-se um material amarelado, assemelhado ao material do horizonte $\mathrm{Bw}$ deste perfil. Todas estas observações são evidências da ação efetiva da fauna do solo no revolvimento do perfil, dispersando o carvão que se acumularia preferencialmente na superficie ou próximo dela 
(fragmentos de carvão foram encontrados em profundidade superior a $5 \mathrm{~m}$ ), movimentando os fragmentos de gnaisse ferruginizado ao longo do perfil e depositando em câmaras, canais e cavidades mais superficiais, o material obtido em escavações profundas (abaixo de $2 \mathrm{~m}$ ).

A análise das amostras indeformadas com a lupa corrobora os aspectos estruturais descritos no campo, se assemelha a descrição na mesma escala feita para Ple Extra 64 e confirma a atividade biológica mais intensa neste perfil e a sua participação decisiva na microagregação deste horizonte. São tantos biopedotúbulos que se cruzam que fica dificil distingui-los (Figura 35). Microagregados plásmicos esféricos, bruno claros, menores que $0,1 \mathrm{~mm}$ estão unidos a fragmentos de carvão e areia (quartzo) para formar microagregados arredondados, bruno escuros e brilhantes, menores que $1 \mathrm{~mm}$, zoogenéticos, que ocupam $95 \%$ da amostra estudada. Também ocorrem alguns agregados maiores (de até $2 \mathrm{~mm}$ ) que apresentam as mesmas características que os anteriores. Raros são os agregados poliédricos. Poros são abundantes e raízes finas e muito finas são comuns. As paredes das cavidades e canais de origem biológica são cimentadas, confirmando o adensamento do plasma nestes locais, observados nas lâminas delgadas.

$\mathrm{A}$ análise micromorfológica feita em 3 subhorizontes de $\mathrm{A}$ húmico (Ap, A2 e A3) confirma a morfologia descrita no campo e nas caixas. A trama é predominantemente grânica, o esqueleto é constituído por quartzo (15\%) e carvão (4\%) e a porosidade ocupa cerca de $50 \%$ da área observada, sendo constituída por cavidades e canais de origem biológica, fissuras e poros fissurais (Figura 36). Os dois últimos também apresentam orientação preferencial SE-NW, como encontrada em P1 e Extra 64. Nas raras paredes de biopedotúbulos preservadas verifica-se um adensamento do plasma (cimentação das paredes das cavidades e canais descrita na caixa). Como verificado nos perfis anteriores, a gênese dos microagregados deste horizonte pode ser zoogenética, microestrutural ou complexa. Porém, microagregados com gênese atribuída a ação da fauna do solo (esqueleto interno triado composto por quartzo e carvão ovalado e arestado, forma arredondada ou ovalada, cor mais escura e brilhante) dominam amplamente este 


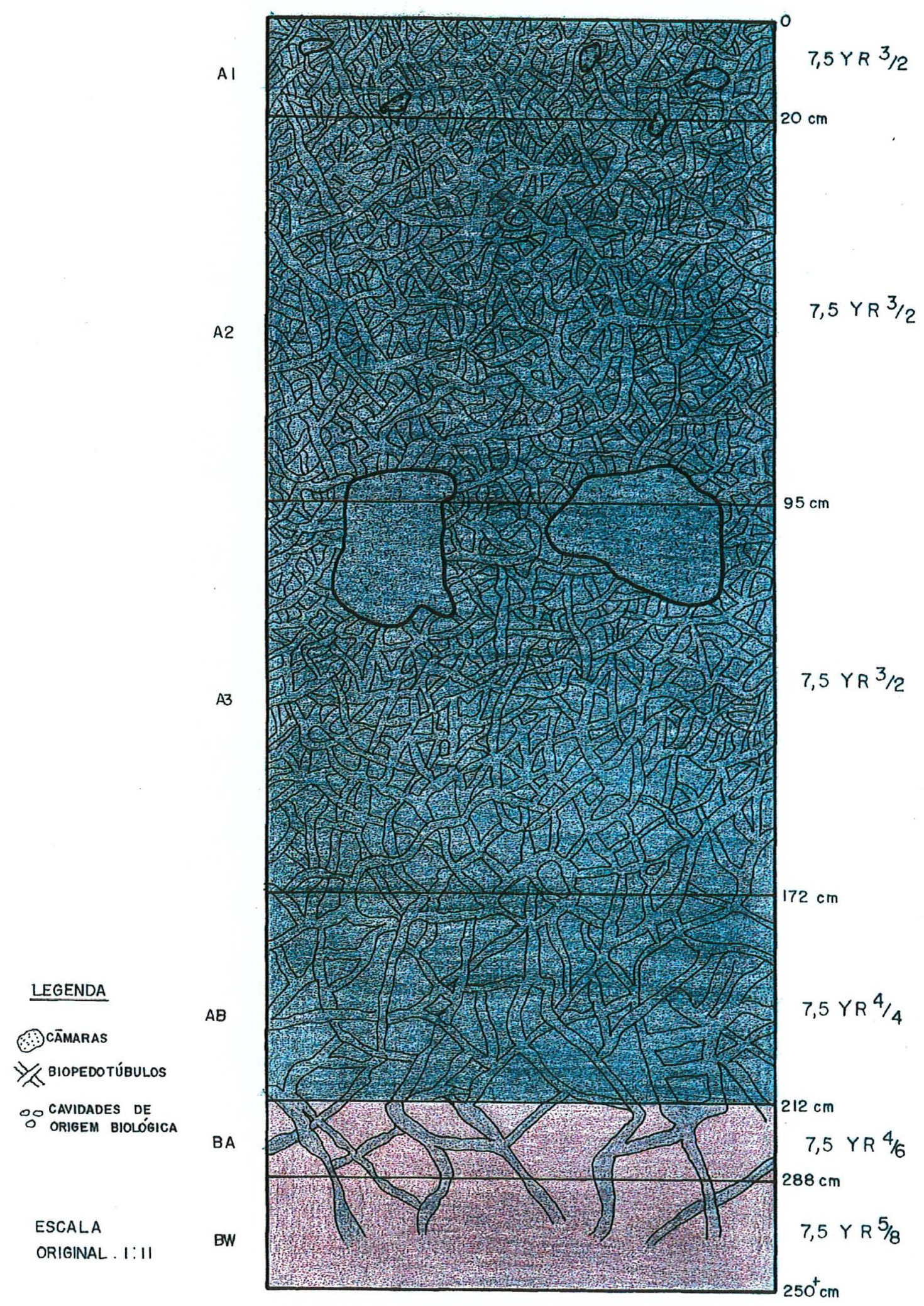

Figura 35. Arranjo dos biopedotúbulos e cor dos horizontes de (2 (Latossolo Vermelho-Escuro Húmico) 


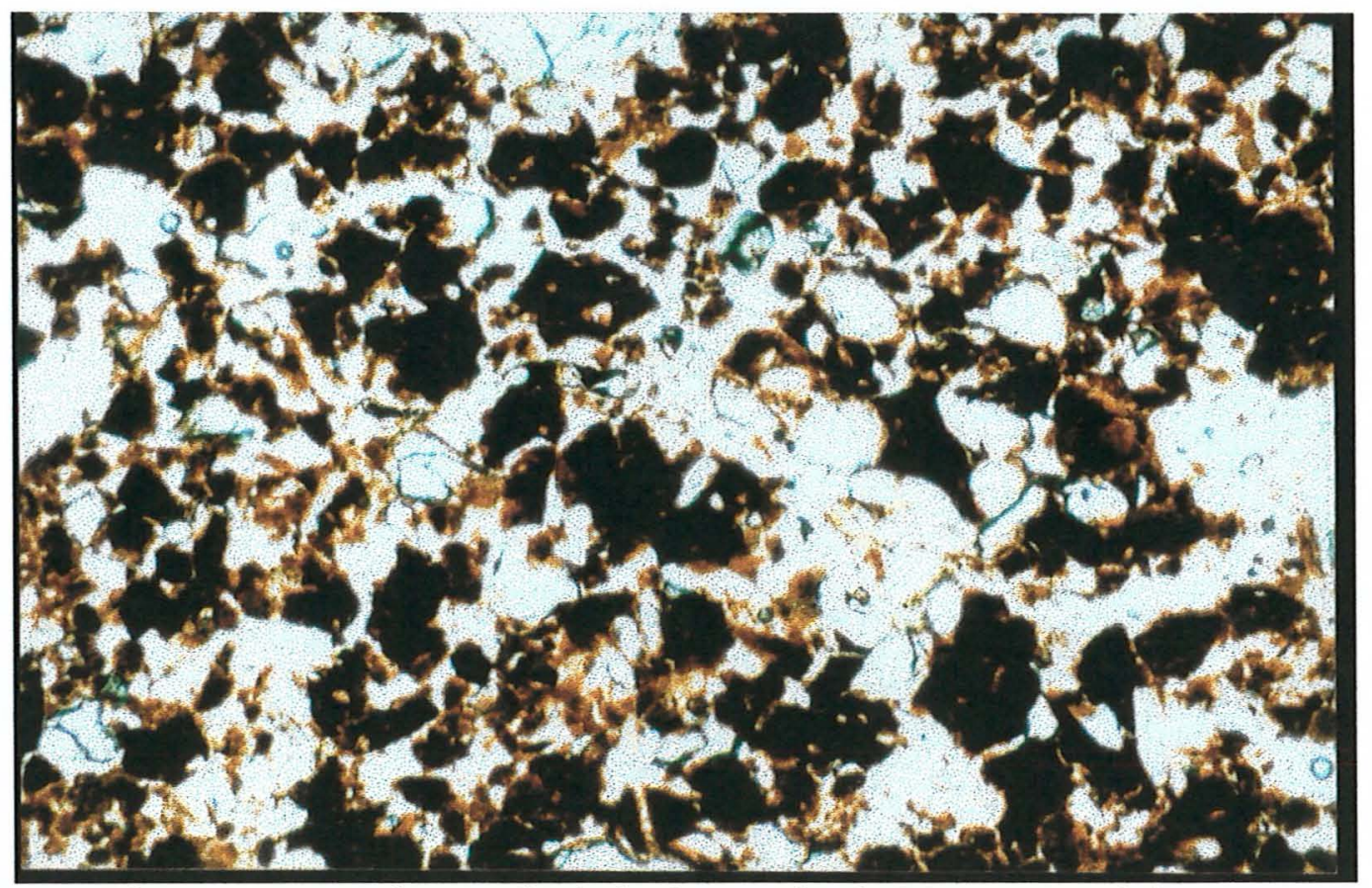

Figura 36. Fotomicrografia do horizonte Ap de P2. Trama grânica.

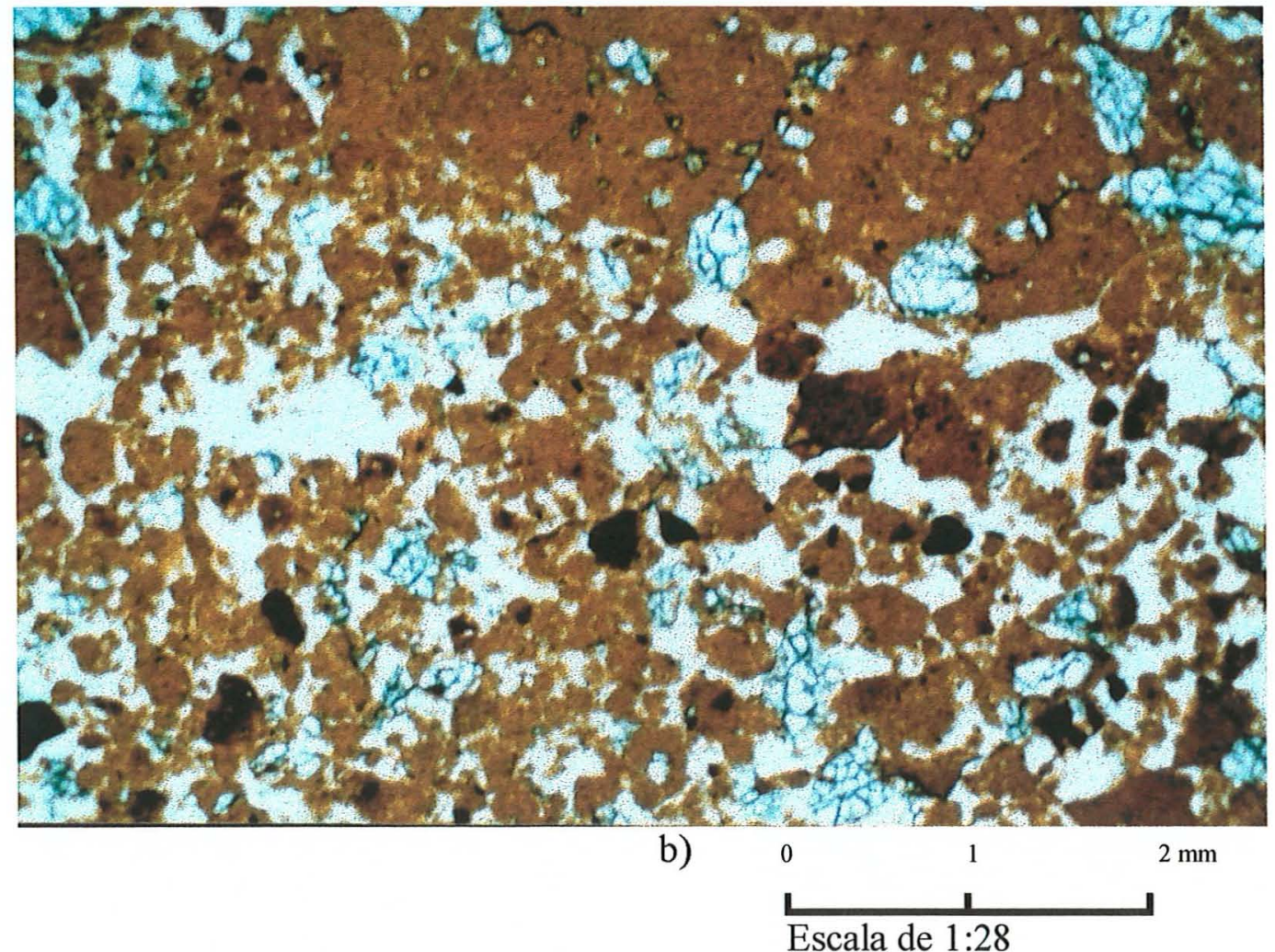

Figura 37. Fotomicrografia do horizonte Bw de P2. Trama grânica-granóidica 
horizonte. Uma câmara de formigueiro preenchida (panela de formigueiro), com $20 \mathrm{~cm}$ de diâmetro maior, teve seu material de enchimento amostrado e analisado fisica, química, mineralógica e morfologicamente. Os exames revelaram uma semelhança física, química, morfológica em relação ao material amostrado em local adjacente a esta cavidade. Apenas a mineralogia caulimítica da fração argila (Apêndice 4) deste material difere da mineralogia caulinítico-gibbisítica das argilas do material adjacente. Estes resultados mineralógicos não confirmam a tendência da mineralogia mais gibbsítica encontrada por Schaefer (1996) em materiais que preenchem biopedotúbulos de latossolos.

A análise deste enchimento de canais e cavidades reforça a hipótese do papel fundamental da ação da fauna do solo na microagregação e na formação do horizonte $\mathrm{A}$ húmico, já que este tem o aspecto de um grande biopedotúbulo preenchido, formado pela coalescência de inúmeros biopedotúbulos menores (Figura 35).

O horizonte $\mathrm{Bw}$ de $\mathrm{P} 2$ apresenta espessura de $3,0 \mathrm{~m}$, cores amareladas e teores de argila superiores a $60 \%$. A fração argila é formada por caulinita e gibbsita. Feldspatos e micas compõe a fração silte (Apêndice 4) e os teores de Fe total, Ti total, $\mathrm{Zr}$ total e relação Ti/Zr são respectivamente $73 \mathrm{~g} \mathrm{~kg}^{-1} ; 2,6 \mathrm{~g} \mathrm{~kg}^{-1} ; 347 \mathrm{mg} \mathrm{kg}^{-1}$ e 7,61 . É ácido, sua CTC é menor que $6 \mathrm{cmol}_{\mathrm{c}} \mathrm{kg}^{-1}$, seu valor $\mathrm{S}$ é inferior a $2,11 \mathrm{cmol}_{\mathrm{c}} \mathrm{kg}^{-1}$, e seus teores de Al trocável diminuem gradativamente em profundidade, até se aproximar de zero e permanecer constante. Tal observação confirma a inferência da complexação do alumínio pela matéria orgânica nos horizontes superficiais (Stevenson, 1982: Melo,1994), já que o alumínio não ocorre nem mesmo no horizonte $\mathrm{CB}$, onde a matéria orgânica não é encontrada.

A estrutura de Bw foi descrita como blocos subangulares fracos e grandes que se desfaz em forte, muito pequena, granular. Biopedotubúlos preenchidos com até $4 \mathrm{~cm}$ de diâmetro ocorrem com frequência, ocupando cerca de $20 \%$ do perfil. No horizonte BA os biopedotúbulos ocupam $40 \%$ do perfil e também estão preenchidos por microagregados menores que $1 \mathrm{~mm}$ arrendondados, brunados, alguns com esqueleto triado, outros só plásmicos. A diminuição do remonte biológico com a profundidade do 
solo, como foi evidenciada anteriormente, coincide com a diminuição do teor de microagregados zoogenéticos.

A descrição das amostras indeformadas revelou a presença de microagregados menores que $1 \mathrm{~mm}$ arredondados em sua maioria, predominantemente plásmicos, com menor quantidade de areia e carvão dentro deles, em relação aos horizontes sobrejacentes. Poucos agregados, poliédricos ou arredondados, formados pela união de microagregados são encontrados neste horizonte. Muitos poros são encontrados entre os microagregados, mas raízes são raras.

$\mathrm{O}$ exame das lâminas delgadas do horizonte $\mathrm{Bw}$ de $\mathrm{P} 2$ revelou internamente o que foi observado nas escalas menores, mas tridimensionais, de descrição morfológica. A pedalidade também é elevada e a trama é grânica-granóidica. Porém, em cerca de $20 \%$ da lâmina a trama é porfirítica. $O$ esqueleto é formado por fragmentos de quartzo (média de $0,25 \mathrm{~mm}$ ) predominantemente arredondados e de carvão, arredondados e poliédicos, com tamanho médio de $0,15 \mathrm{~mm}$. A porosidade ( $50 \%$ da área da lâmina) é predominantemente biológica, com domínio de canais e cavidades, mas também ocorrem fissuras e poros fissurais com direção predominante SE-NW. Estas fissuras predominam nas áreas de lâmina com trama porfirítica, que parecem corresponder as áreas entre os biopedotúbulos. Mesmo com a trama bem adensada nestes locais, ainda consegue-se perceber a silhueta dos microagregados menores que $0,1 \mathrm{~mm}$, arredondados, predominantemente plásmicos, que estariam se formando novamente por ação geoquímica, depois de serem coalescidos pela ação da fauna do solo. Assim, da mesma forma que no horizonte $\mathrm{Bw}$ de P1 e de Extra 64, situados a montante, teríamos a formação de agregados por zoogênese, microestruturação, complexação e geoquímica, em um processo cíclico e interligado, com o adensamento do plasma provocado pelos movimentos de massa. Dentro dos biopedotúbulos, que ocupam apenas $20 \%$ deste horizonte, mas são observados em $80 \%$ da lâmina, têm-se microagregados menores que $1 \mathrm{~mm}$, arredondados com esqueleto triado, de coloração brunada mais intensa e outros microagregados de igual tamanho também arredondados e brunados, mas predominantemente plásmicos, formados pela coalescência de outros microagregados arredondados menores que $0,05 \mathrm{~mm}$. 
Os horizontes $\mathrm{BC}$ e $\mathrm{CB}$ de $\mathrm{P} 2$, que ocorrem a partir de $530 \mathrm{~cm}$ de profundidade, são mais arenosos e siltosos que os sobrejacentes. Mas guardam semelhanças com o Bw em cor, Valor S, CTC e teor de matéria orgânica (estes em um patamar um pouco inferior) e apresentam a mesma mineralogia das frações silte e argila, assim como teores de $\mathrm{Fe}, \mathrm{Ti}, \mathrm{Zr}$ e relação $\mathrm{Ti} / \mathrm{Zr}$ bem próximas a encontradas para o horizonte diagnóstico deste solo (Apêndice 4).

Analisando-se P2 como um todo, pode-se inferir que o mesmo é um solo muito profundo e permeável (elevada porosidade), muito lixiviado (baixas CTC e valor $\mathrm{S}$ ), originado a partir de materiais provenientes de seu saprolito, transportados a curta distância e intensamente remontados pela atividade biológica.

\section{Perfil 3 (sopé côncavo)}

Continuando a descida pela vertente sudoeste do SMI, encontra-se, após o segundo controle estrutural que forma um anfiteatro suspenso (Figura 29 A) na linha de drenagem adjacente, um novo segmento de encosta de cobertura também latossólica, que, termina em uma depressão semi-fechada onde também ocorre um latossolo de elevada permeabilidade (T 93). No sopé deste segmento de encosta, a cerca de $140 \mathrm{~m}$ do centro da depressão, foi aberta uma trincheira (P3) e realizada uma tradagem profunda, que alcançou 6,0m. O solo foi classificado como Latossolo Vermelho Amarelo Húmico, de textura argilosa (P3). Este solo apresenta, até $4 \mathrm{~m}$ de profundidade, os mesmos atributos químicos, mineralógicos, físicos, morfológicos e micromorfológicos que os dos perfis descritos a montante (Extra 64, P1 e P2). Porém, a densidade do solo, em todos os seus horizontes, foi a mais elevada entre a de todos os latossolos estudados. A descrição de lâmina delgada de seu horizonte Bw revelou uma trama predominantemente porfirítica e menos comumente granóidica, com esqueleto composto de fragmentos de quartzo arestado e carvão poliédrico ou arredondado (Figura 24). A porosidade dominante é a fissural, com as fissuras nitidamente orientadas na direção SE-NW. Sua estrutura de campo , na maior parte moderada, média, blocos sub angulares, corresponde a descrição da lâmina. 
Abaixo de $4 \mathrm{~m}$ de profundidade, ocorre uma mudança significativa nos atributos do material de origem de P3. A cor passa de amarelo-avermelhada para vermelha (7,5 YR para 2,5 YR) e, apesar dos teores de argila diminuirem gradativamente e o teor de silte aumentar, a CTC e o valor S se elevam. Os teores absolutos de areia total aumentam em até $30 \%$ e os teores relativos de areia grossa diminuem em até $300 \%$. A mineralogia da fração argila passa a caulinítica e os teores de Fe e $\mathrm{Zr}$ totais diminuem e a relação Ti/Zr passa de 8,7 para 13,0 (Figura 23); diferença esta que se situa fora do intervalo que Dress \& Wilding (1973) estabeleceram para caracterizar materiais homogêneos. Estes atributos são semelhantes aos da cobertura pedológica da colina adjacente, localizada mais a sudoeste, onde se situa o perfil P4, classificado como Latossolo Vermelho Escuro de textura muito argilosa.

Esta descontinuidade litológica, juntamente com o adensamento de todo o perfil (evidenciado pelos maiores valores de Ds) e a trama porfiritica com fissuras orientadas, encontrada em Bw, se constituem em evidências da ação dos movimentos de massa, remanejando materiais pédicos a curta distância. A ausência de fragmentos de carvão de idade recente na superficie de P3 (Tabela 3), discutida no capítulo 4.5, também se constitui em evidência da ação dos movimentos de massa.

Os solos dos segmentos de encosta do SMI discutidos até aqui, representados pelos perfis Extra 64, P1, P2 e P3 (este último até 4,0 m de profundidade) são, provavelmente, os mais desenvolvidos (antigos) e intensamente intemperizados deste sistema morfopedológico. Por sua ocorrência nas altitudes mais elevadas, por sua posição na encosta e por seus atributos físicos, químicos, mineralógicos e micromorfológicos, eles podem ser considerados paleossolos, vestígios da Superfície de aplainamento Sul-Americana, descrita por King (1956). Tratam-se de solos muito profundos e lixiviados, cujo intemperismo das suas rochas formadoras iniciou-se no Mioceno Superior, com a reinstalação de condições úmidas, após um período seco muito prolongado, como o citado por Penteado (1968) e Melo (1995), para a Depressão Periférica Paulista. A colonização destes ambientes por térmitas, formigas e vegetação florestal foi contemporânea e atuante na pedogeneização do saprolito até então formado, iniciando o processo que culminou com a latolização do mesmo. 
A partir do Mioceno Médio, o soerguimento das Serras do Mar e da Mantiqueira causou a reativação de falhas (Saadi, 1991), o que teria levado ao basculamento de blocos de rocha para SW e transporte a custa distância deste manto latossólico. Estes movimentos de massa causaram a exposição de rochas nos topos e contribuiram para o espessamento do horizonte $\mathrm{A}$ e adensamento e fissuração do horizonte $\mathrm{Bw}$, nestes segmentos de encosta. A constante e intensa atividade biológica foi fator fundamental para o espessamento do horizonte A e diminuição de sua densidade. A rede de drenagem também teria sido reinstalada a partir desta época.

Apesar da idade atribuída a esta cobertura latossólica, sua mineralogia caulinítico-gibbsítica, mas predominantemente caulinítica, é discordante da maior parte das referências encontradas na literatura para solos do Terciário, cuja mineralogia é predominantemente gibissítica, devido à retirada da silica do sistema por lixiviação. Porém, a presença de vegetação com elevada relação biomassa/área pode minimizar esta perda de sílica. Lucas et al. (1993), em trabalho conduzido na Floresta Amazônica, concluíram que o silício é o segundo elemento mais reciclado pela cobertura vegetal de grande porte. Esta reciclagem bioquímica do silício manteria o sistema com concentrações deste elemento no campo de estabilidade da caulinita, em detrimento da gibbsitização do material pedológico, pois seu teor permaneceria elevado na solução do solo. Para Schaeffer (1996) áreas intercratônicas de Minas Gerais apresentaram cobertura florestal no Terciário, primeiramente colonizadas por coníferas e posteriormente por angiospermas. Esta cobertura, presente até os dias atuais, contribuiria, então, para o favorecimento da caulinita em um sistema caulinítico-gibbsítico.

\section{Perfil 4 (sopé côncavo)}

Caminhando-se para sudoeste, sempre no interflúvio, alcança-se o sopé côncavo da próxima encosta (declives entre 4 e 10\%), onde foi descrito o perfil 4 (P4) e o solo foi classificado como Latossolo Vermelho Escuro distrófico A proeminente textura argilosa (Figura 5). É um solo muito profundo (o horizonte Bw apresenta 4,3 m de espessura), muito permeável e homogêneo, apresentando cores no matiz 2,5 YR e 
granulometria muito argilosa por todo o perfil. As transições entre os horizontes e subhorizontes são graduais ou difusas.

Seu horizonte A proeminente tem $82 \mathrm{~cm}$ de espessura, teores de matéria orgânica variando entre 16 e $10 \mathrm{~g} \mathrm{~kg}^{-1}$, CTC em torno de $9 \mathrm{cmol}_{\mathrm{c}} \mathrm{kg}^{-1}$ e valor S entre 2,35 e e $2,94 \mathrm{cmol}_{\mathrm{c}} \mathrm{kg}^{-1}$. A mineralogia da fração silte é formada por quartzo, feldspato, mica e ilita e a da argila é composta por caulinita. A estrutura de A proeminente foi descrita no campo como moderada, média, em blocos subangulares, que se desfazem em forte muito pequena granular. A atividade de cupins e formigas é intensa e comumente são encontrados biopedotúbulos com até $3 \mathrm{~cm}$ de diâmetro.

A descrição de amostras indeformadas deste horizonte revela o predomínio de agregados maiores que $2 \mathrm{~mm}$ de diâmetro, poliédricos ou arredondados, resultantes da união de agregados arredondados, plásmicos, menores que $1 \mathrm{~mm}$ de diâmetro, com fragmentos de areia e de carvão. Estes microagregados também podem ocorrer isoladamente. Agregados com superficie lisa e brilhante também ocorrem, possivelmente advindos da destruição de cavidades de origem biológica. Muitos biopedotúbulos ocorrem neste horizonte e a porosidade dentro e entre os agregados é elevada. Raízes também são comuns. A quantidade de fragmentos de carvão menores que $1 \mathrm{~mm}$ aumenta com a profundidade.

A descrição micromorfológica das lâminas deste horizonte revelou uma pedalidade bastante desenvolvida, com trama predominantemente grânica-granóidica dentro dos biopedotúbulos e granóidica fora dos biopedotúbulos. Os grãos do esqueleto são partículas de quartzo (10\%) e carvão (3\%), arredondados, subarrendondados e poliédricos. A porosidade ( $40 \%$ da área da lâmina) é formada por canais e cavidades de origem biológica, além de poros fissurais alongados e circulares. Algumas destas fissuras estão preenchidas por material plásmico não agregado, de coloração alaranjada (Figura 38). A orientação SE-NW destes poros fissurais não é tão evidente em relação àquela encontrada nos perfis discutidos anteriormente. Os biopedotúbulos estão preenchidos por microagregados, arredondados, material plásmico pouco nítido (quase transparente), raízes e grãos de areia e carvão de tamanho e formas variadas, dentro ou fora dos microagregados. Suas paredes são adensadas e apresentam trama 


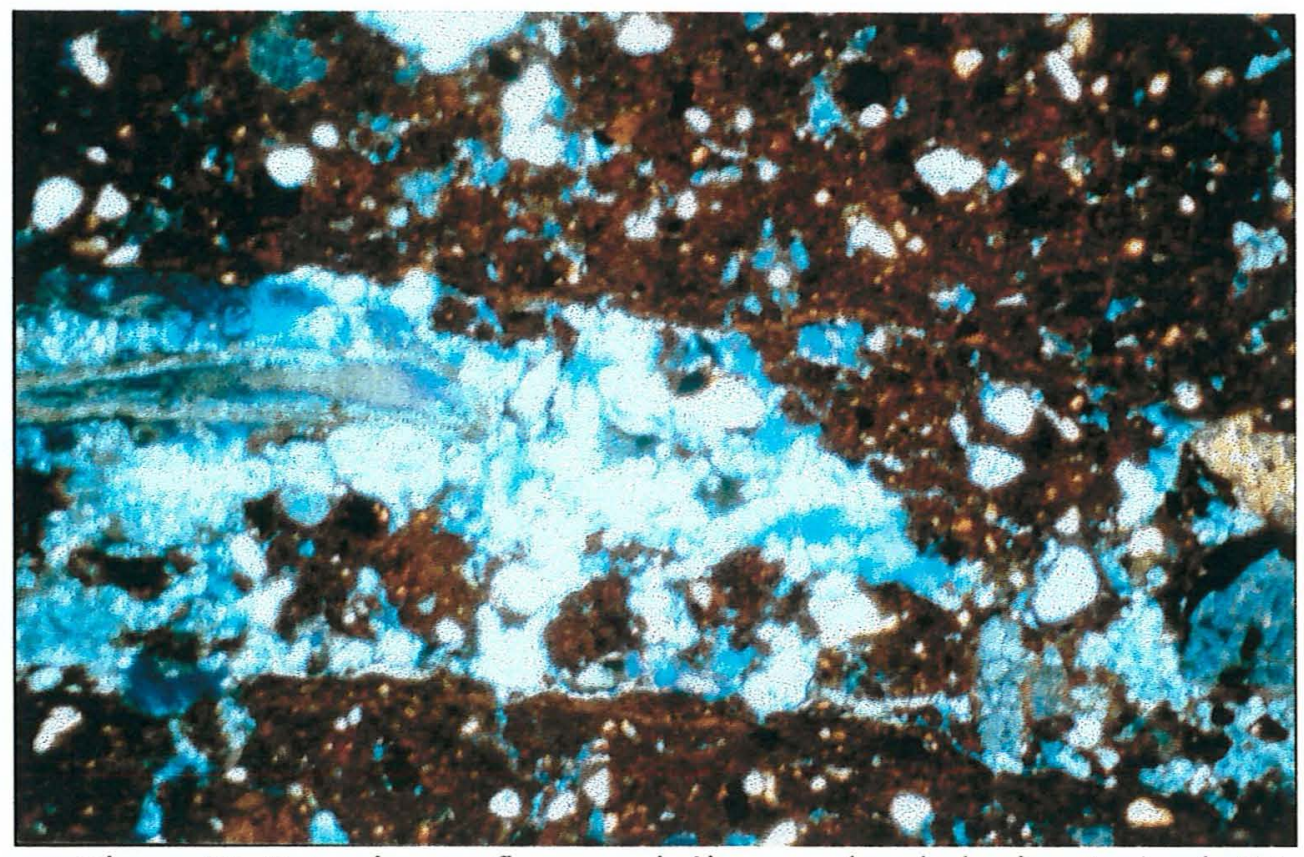

Figura 38. Fotomicrografia com nicóis cruzados do horizonte Ap de P4.

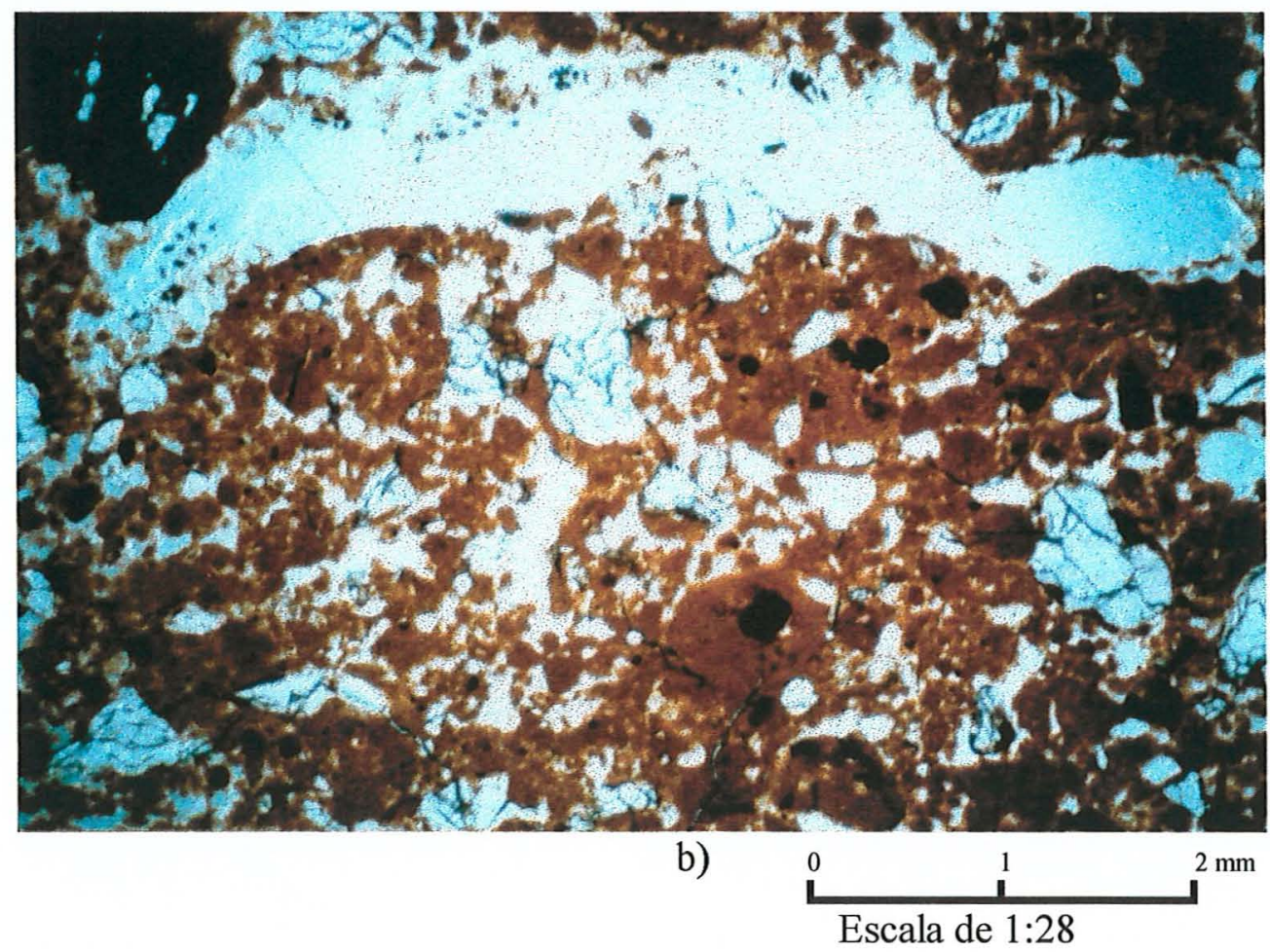

Figura 39. Fotomicrografia do horizonte Bw de P4. 
profirítica fissurada. Os microagregados são predominantemente arrendondados, de coloração bruno escura ou bruno alaranjada, plásmicos ou com esqueleto interno triado. Seu tamanho varia entre 0,2 e $0,02 \mathrm{~mm}$ e muitos dos maiores são formados pela coalescência dos pequeninos.

Muitos dos microagregados são zoogenéticos, outros são complexos ou microestruturais. Porém, a fissuração circular preenchida com plasma mais alaranjado (Figura 38), é um forte inídicio da origem geoquímica de muitos destes microagregados por desferrificação parcial de micronódulos formados por caulinitas ligadas por pontes de óxidos de ferro, de acordo com o modelo proposto por Chauvel (1978), citado por Stoops (1985).

O horizonte $\mathrm{Bw}$ de $\mathrm{P} 4$ é espesso, apresenta cores avermelhadas, CTC baixa, Valor $\mathrm{S}$ menor que $2,7 \mathrm{cmol}_{\mathrm{c}} \mathrm{kg}^{-1}$ e teores de materia orgânica próximos de zero (Apêndice 3 ). A fração silte é formada por feldspatos e mica, enquanto que as argilas são cauliníticas. Os teores de areia grossa, areia média e areia fina são equitativos e predominam na fração areia total. Sua densidade é de $1,22 \mathrm{t} \mathrm{m}^{-3}$, cerca de $20 \%$ superior à Ds do horizonte A. Seus teores de ferro total oscilam entre 53 e $61 \mathrm{~g} \mathrm{~kg}^{-1}$, os de titânio total entre 6,1 e $7,1 \mathrm{~g} \mathrm{~kg}^{-1}$, os de zircônio total entre 518 e $463 \mathrm{mg} \mathrm{kg}^{-1}$ e a relação $\mathrm{Ti} / \mathrm{Zr}$ entre 13,22 e 13,77 (Apêndice 4), próxima a encontrada para o horizonte Bt de P7 e fora do intervalo encontrado por Dress \& Wilding (1973) para separar materiais de litologias diferentes.

Sua estrutura é composta de blocos subangulares médios e moderados, que se desfazem em granular muito pequena e muito forte e em alguns blocos subangulares pequenos e fortes. A atividade de formigas e cupins é intensa, sendo corriqueira a presença de biopedotúbulos, que correspondem a $10 \%$ do volume da amostra indeformada. A descrição desta revelou um domínio de microagregados menores de $1 \mathrm{~mm}$, alaranjados, formados pela união de microagregados ainda menores, areia e carvão. Muitos destes microagregados apresentam superficie lisa e brilhante, que foi descrita no campo como cerosidade fraca e pouca. Dentro dos biopedotúbulos os microagregados são arredondados, bruno alaranjados e menores que os que estão fora destes canais de origem biológica. Muitos deles não apresentam areia ou carvão. 
Através da descrição das lâminas delgadas observou-se uma pedalidade muito desenvolvida em Bw, cuja trama é granóidica (plasma menos adensado), os grãos do esqueleto são de quartzo arestado (15\%) e fragmentos de carvão (3\%) arestados e arredondados, de tamanho variado, e a porosidade é formada por cavidades e canais e secundariamente por fissuras e poros fissurais, também orientados preferencialmente na direção SE-NW. Um dos canais, com cerca de $1 \mathrm{~mm}$ largura, está parcialmente preenchido por coprólitos ovalados, de cerca de $0,02 \mathrm{~mm}$, envoltos em um plasma praticamente transparente (Figura 39). Tal feição parece indicar um fenômeno de atração entre os coprólitos e este tipo de plasma, que estaria desferrificado. Esta desferrificação pode ser considerada uma evidência de ação geoquímica. A cerosidade de campo foi observada como material fino revestindo microagregados zoogenéticos e preenchendo alguns poros fissurais.

Os microagregados encontrados neste horizonte têm sua gênese atribuida aos hábitos construtor e alimentar de termitas e formigas, a complexação e a geoquímica. A microestruturação é rara e a gênese por complexação é a mais comum.

Os atributos físicos, químicos, mineralógicos e morfológicos de $\mathrm{P} 4$ são semelhantes aos encontrados para o horizonte Bw que ocorre em P3, abaixo de $4 \mathrm{~m}$ de profundidade. Porém, diferem grandemente dos mesmos atributos encontrados nos perfis Extra 64, P1, P2 e P3 (até 4,0m de profundidade). Estes resultados comprovam a descontinuidade litológica existente em P3. A mineralogia caulinítica deste solo, comparada com a mineralogia caulinítico-gibbsítica dos solos anteriores pode ser um indício do menor desenvolvimento deste solo, cujo material de origem só foi exposto à superfície, portanto, sujeito a um intemperismo mais intenso, após o basculamento de blocos no Terciário Inferior que provocou os movimentos de massa. Outras evidências são o plasma menos adensado que os anteriores, sua cor mais vermelha e a desferrificação parcial e localizada do plasma. A localização deste solo no sopé favoreceu a latolização do material pedológico oriundo de rochas granulíticas do Complexo Guaxupé expostas à superfície pela ação da tectônica ressurgente. Esta latolização possivelmente se deu a partir de solos podzólicos como os que serão descritos e caracterizados a seguir. 


\section{Perfil 6}

O sopé desta colina onde foi descrito P4 transiciona abruptamente para uma meia-encosta retilíneo-conexa, onde os declives oscilam entre 20 e $48 \%$ (Figura 5). Esta meia encosta limita no topo com afloramentos de rocha e solos pouco profundos. Em posição semelhante, porém do outro lado da colina, foi descrito um perfil de solo (P6), classificado como Podzólico Vermelho Escuro distrófico, $\mathrm{Tb}$, textura argilosa/ muito argilosa, último solo da vertente SW do SMI estudado.

$O$ horizonte A deste solo é muito estreito (tem apenas $9 \mathrm{~cm}$ ), sugerindo atuação de erosão laminar, pois a área é muito declivosa e está formada com uma pastagem degradada de Brachiaria decubens. Terracetes também são encontrados numa área deste segmento de encosta, onde a declividade atinge $61 \%$. As cores deste horizonte são escuras, seu teor de matéria orgânica é mediano assim como os são a CTC e o Valor S. Fragmentos de carvão e de gnaisse em decomposição são encontrados por todo o horizonte. $\mathrm{O}$ valor de densidade de $1,17 \mathrm{t} \mathrm{m}^{-3}$ na superficie está influenciado pelo pisoteio animal. A atividade biológica é considerável. Suas unidades estruturais foram classificadas como blocos subangulares, pequenos e médios, moderados a fortes. $\mathrm{O}$ exame das amostras indeformadas revelou o predomínio de agregados de 2 a $3 \mathrm{~mm}$ de diâmetro, poliédicos, formados pela união entre partículas de areia de tamanho variado, material plásmico e fragmentos de carvão. Estes agregados são bruno avermelhados e se unem a outros para formar os blocos, que encontram-se fissurados. A porosidade entre estes é grande, mas dentro deles é pequena. Raízes estão presentes em grande quantidade.

A observação das lâminas delgadas confirma muito dos atributos descritos no campo. A pedalidade é muito desenvolvida, a trama é predominantemente porfirítica (Figura 40), mas intensamente fissurada, também com orientação predominante SE-NW. O plasma é denso e bruno avermelhado. O esqueleto é constituído por grãos de quartzo (20\%) e carvão (2\%), arestados e arredondados e de tamanho desuniforme. A porosidade ocupa $20 \%$ da área analisada e é predominantemente fissural, mas também ocorrem canais e cavidades de largura inferior a $0,2 \mathrm{~mm}$. Esta descrição corresponde aos blocos subangulares encontrados por análise tridimensional dos agregados no campo e em 


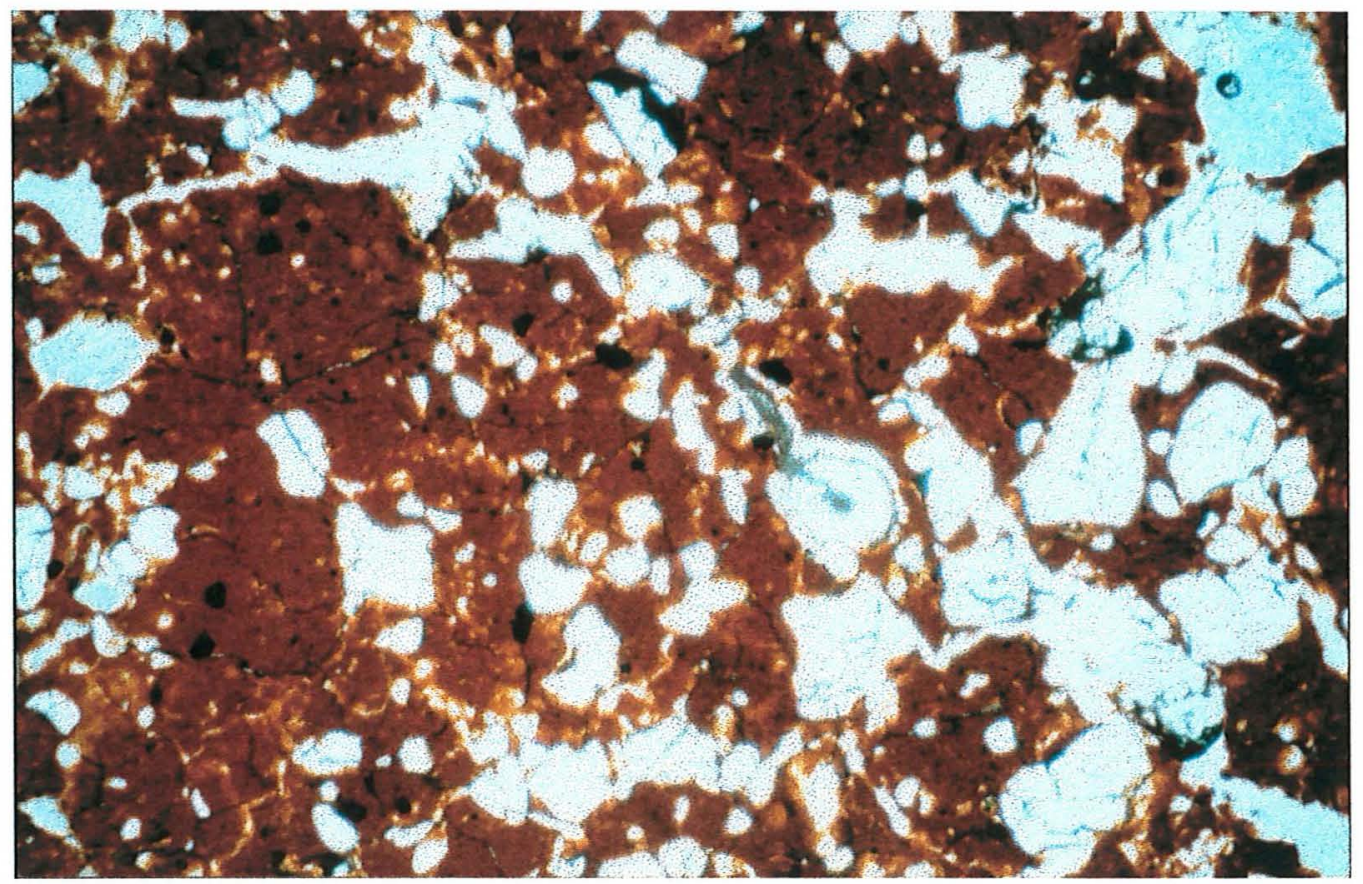

Figura 40. Fotomicrografia da transição entre os horizontes $\mathrm{A}$ e $\mathrm{AB}$ de $\mathrm{P} 6$.

Trama porfirítica

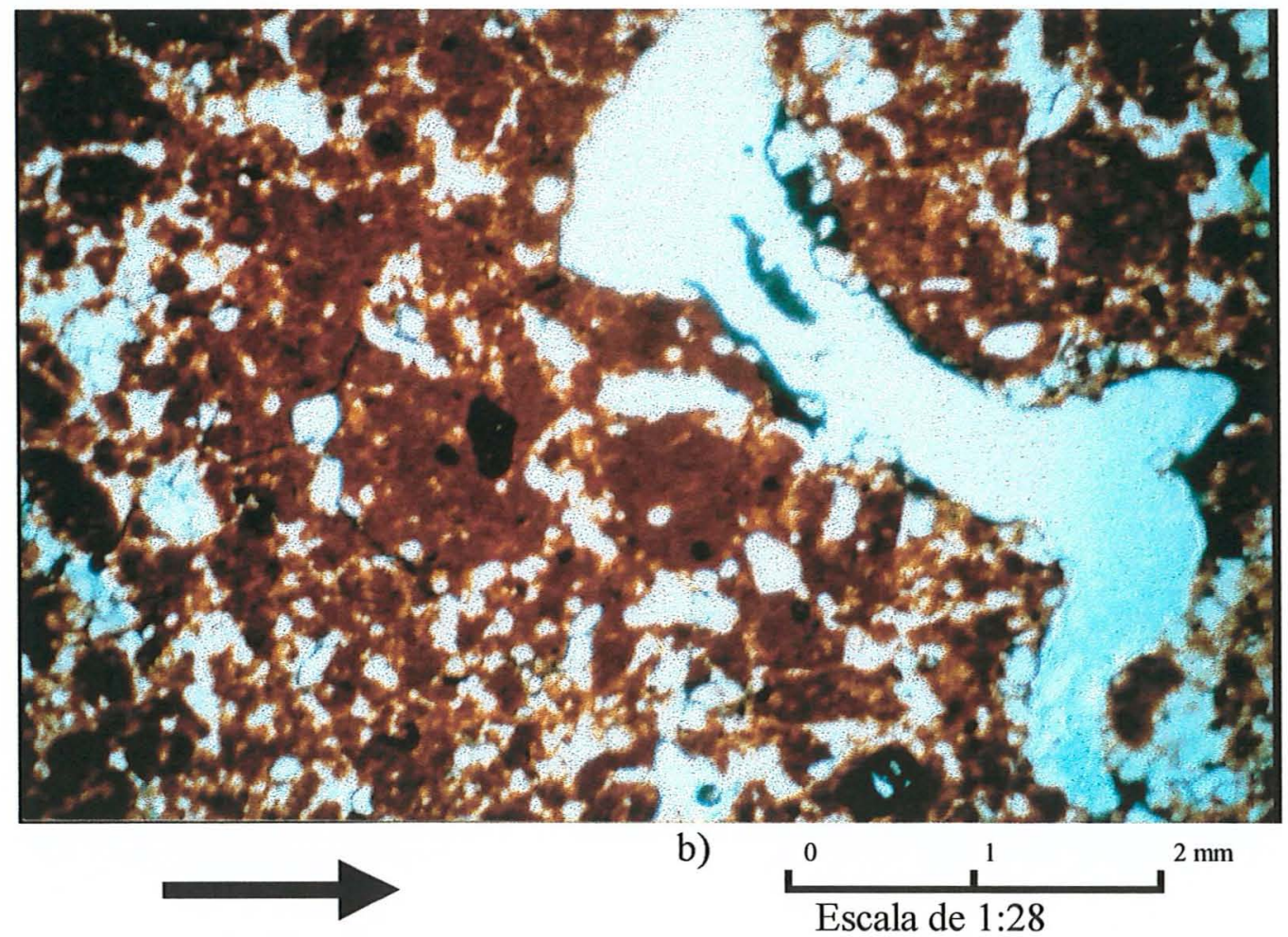

Figura 41. Fotomicrografia do horizonte Bw de P6. Ferriargilãs nas paredes das cavidades, argilãs entre os microagregados e descolorimento do plasma. 
amostras indeformadas. Os poucos microagregados de origem biológica ocorrem nos biobiopedotúbulos e a presença de microagregados microestruturais não é significativa.

Os horizontes transicionais de P6 apresentam cores avermelhadas, CTC, em torno de $7 \mathrm{cmol}_{\mathrm{c}} \mathrm{kg}^{-1}$ e valor $\mathrm{S}$ ao redor de $2 \mathrm{cmol}_{\mathrm{c}} \mathrm{kg}^{-1}$ (Apêndices 1 e 3). Fragmentos de carvão e de gnaisse em decomposição ocorrem comumente em todo o perfil. A densidade do solo é a maior do perfil, notadamente na camada de 45 a $65 \mathrm{~cm}$ de profundidade, onde também a cerosidade está melhor expressa, descrita como moderada e abundante. $\mathrm{O}$ adensamento do solo nesta profundidade é comumente encontrado para esta classe de solo e é atribuído a ação mecânica do fluxo lateral subsuperficial da água ( Moniz \& Buol, 1982; Lepsch et al., 1977; Vidal Torrado, 1994). A atividade da fauna do solo é menos intensa em relação aos outros horizontes do perfil. A estrutura de BA é constituída de blocos e prismas moderados a fortes, de tamanho pequeno, médio ou grande (Apêndice 1).

A análise das amostras indeformadas demonstrou o predomínio de agregados poliédricos maiores que $5 \mathrm{~mm}$ de diametro, vermelhos, com cerosidade forte e comum em sua superficie. Estes agregados apresentam fissuras e são formados por material plásmico e areia (quartzo), de vários tamanhos. Os fragmentos de carvão são raros e pequenos. Os blocos e prismas deste horizonte são formados pela união destes agregados. Cerca de $5 \%$ das amostras analisadas são biopedotúbulos preenchidos por microagregados arredondados e poliédricos, formados pela união de material plásmico, argila e carvão. Este último é mais comum dentro dos biopedotúbulos, onde também as raízes são abundantes.

Algumas feições observadas nas lâminas evidenciam a argiluviação, processo fundamental para gênese de horizonte Bt. A pedalidade também é bem desenvolvida e a trama é porfirítica ou profirítico-granóidica, com o plasma vermelho e o esqueleto é formado por grãos de quartzo $(20 \%)$ e carvão (1\%). A porosidade é essencialmente cavitária, mas ocorrem também poros fissurais. A presença de argilãs e ferriargilãs recobrindo as paredes dos poros e de descoloração de plasma é muito comum (Figura 41) e comprova a argiluviação. Alguns agregados de origem biológica são observados neste perfil, mas os processos geoquímicos parecem ser os mais ativos atualmente, 
causando a degradação da trama porfirítica a granóidica com consequente formação de microagregados arredondados, de acordo com o modelo proposto por Chauvel (1978), citado por Stoops (1983). Em um clima pretérito úmido, mas com uma estação seca mais bem definida teria ocorrido a migração das argilas. A maior atividade de argilas e o mais elevado valor $S$ dos horizontes superficiais (Apêndice 3) estariam contribuindo para a manutenção do processo no presente, ainda que em menor intensidade. Nas condições úmidas modernas a desferrificação parcial do material em profundidades mais elevadas estaria provocando a microagregação do material. O passo seguinte para a latolização seria a intensificação da biopedoturbação, tal qual possivelmente ocorreu em P4.

A descrição morfológica detalhada dos horizonte $\mathrm{Bt}$ subjacente fortalece a hipótese aventada no parágrafo anterior. Estes Bts são mais avermelhados (matiz 10R), mas a estrutura descrita no campo é semelhante à de BA. Porém, a densidade do solo é mais baixa e a atividade biológica é mais intensa. Estas características são confirmadas pela análise das amostras indeformadas e das lâminas delgadas. A presença de argilãs, ferriargilãs e de plasma descolorido ainda é comum, mas a trama é granóidica com porosidade muito mais elevada, maior ocorrência de biopedotúbulos e de microagregados arredondados de origem geoquímica ou zoogenética (Figura 42). A latolização do horizonte BA é menor que a dos horizontes subjacentes, pois nele a ação mecânica do fluxo lateral subsuperficial da água no solo é mais efetiva e os ciclos de umedecimentosecagem são mais intensos. Vidal Torrado (1994) encontrou agregados de maior tamanho no horizonte $\mathrm{BA}$ em relação ao horizonte $\mathrm{Bw}$, interpretando como um empacotamento de microagregados devido a maior intensidade dos ciclos de umedecimento-secagem nesta zona do solo.

Após a caracterização detalhada da encosta sudoeste do SMI e consulta ao mapa pedológico semi-detalhado da área (Figura 30), verifica-se a ocorrência de uma intrincada distribuição de solos. O esclarecimento desta distribuição pode ser dado por uma análise conjunta das feições geomorfológicas da encosta e de atributos das diferentes coberturas pedológicas. 


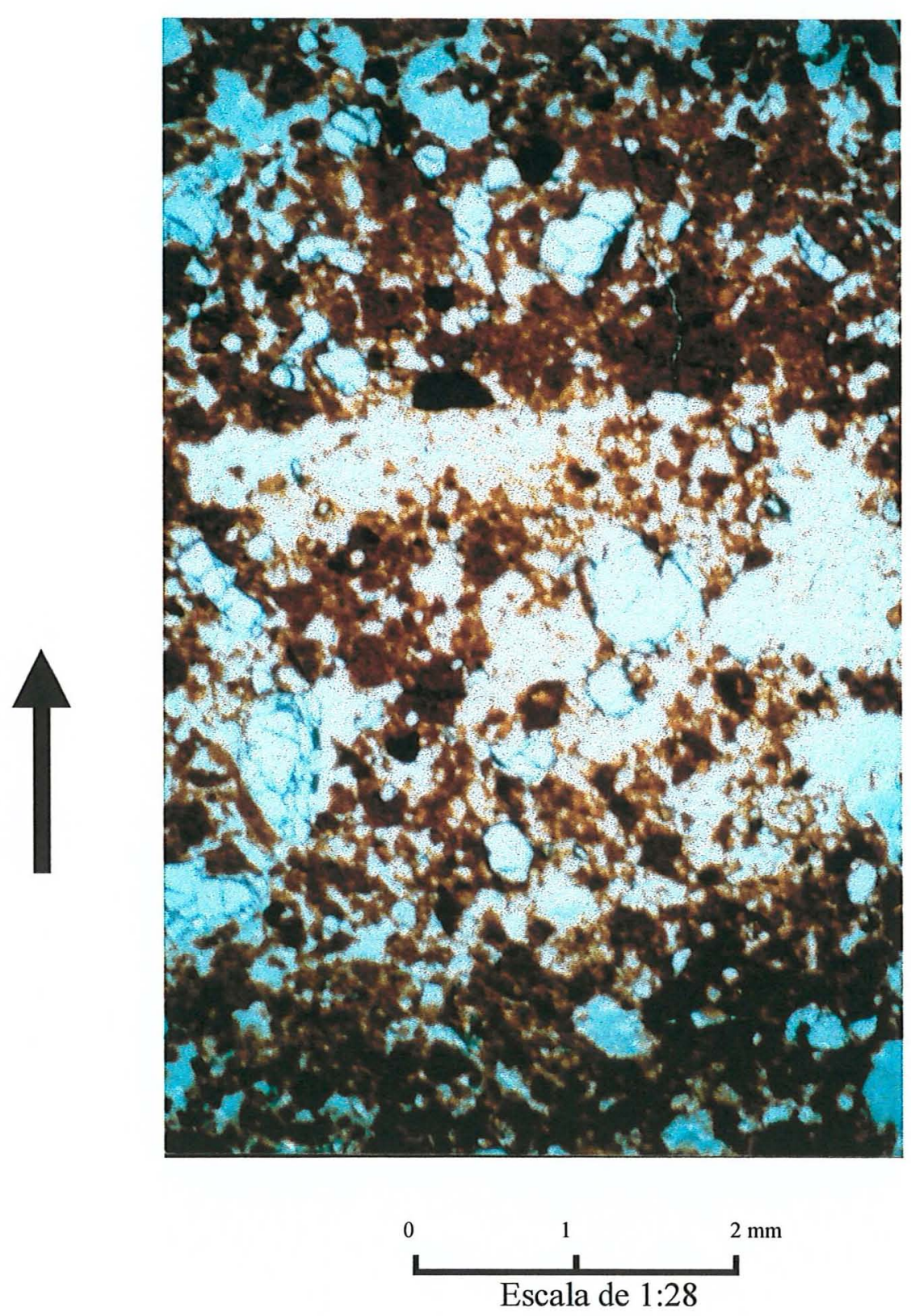

Figura 42. Fotomicrografia do horizonte Bt2 de P6. Trama granóidica

Nos interflúvios em que a cobertura pedológica foi somente remanejada (transportada a curta distância) pelos movimentos de massa e permaneceu cobrindo o saprolito e o embasamento rochoso, a pedogênese foi contínua e intensa. Latossolos muito profundos e permeáveis, com horizonte superficial muito espesso, oriundos de material pré-intemperizado se formaram a partir do Mioceno Superior e permaneceram na paisagem como paleossolos, sendo intensamente revolvidos pela fauna do solo. 
Os locais em que houveram deslizamentos, desabamentos e escorregamentos, expondo os saprolitos e o embasamento rochoso, se constuiriam em via preferencial para novos movimentos de massa e para a ação da erosão hídrica severa ativada por alternâncias climáticas ocorridas no Quartenário (Bigarella et al., 1965a). Estes fenômenos ativaram diversos ciclos de pedogênese, pois as primeiras camadas dos solos (mais pedogeneizadas) são geralmente as primeiras a serem removidas.

\section{Perfis 7 e 8 (encosta nordeste)}

A encosta nordeste do SMI apresenta as feições geomorfológicas características do modelo comentado no parágrafo anterior. Em seus $800 \mathrm{~m}$ de extensão, onde as declividades alcançam até $95 \%$, ocorrem duas escarpas entremeadas por solos pouco desenvolvidos (Podzólico Vermelho-Escuro, eutrófico, tb, A moderado, textura média/ argilosa fase pouco profundo + Litossolo, eutrófico, tb, A moderado, textura média). Entre o topo e a primeira escarpa e no sopé trapezoidal desta vertente ocorrem os solos de maior fertilidade natural da região, classificados em dois perfis (P7 e P8) como Podzólico Vermelho-Escuro, eutrófico, tb, A chernozêmico, textura argilosa/muito argilosa (Figura 5). As diferenças fundamentais entre P7 (descritos a $1.150 \mathrm{~m}$ de altitude) e P8( descritos no sopé da encosta, a $970 \mathrm{~m}$ de altitude) são o horizonte A mais espesso e arenoso em P8, a mineralogia da fração argila, caulinítica em P8 e caulinitica-gibbsítica em P7; e a CTC e o valor $\mathrm{S}$ do horizonte $\mathrm{Bt}$, que alcançam respectivamente $12,3 \mathrm{e}$ $8,7 \mathrm{cmol}_{\mathrm{c}} \mathrm{kg}^{-1}$ em P8 e 7,0 e 4,1 $\mathrm{cmol}_{\mathrm{c}} \mathrm{kg}^{-1}$ em P7 (Apêndice 3). Tais atributos sugerem que $\mathrm{P} 7$ é formado por material mais intemperizado, com a erosão sendo mais intensa nas camadas superficiais, devido a sua posição na encosta. Já P8 situa-se em zona de acúmulo de materiais carreados pela erosão (horizonte A mais espesso e arenoso) e de produtos de solubilização do regolito e das rochas situadas a montante, como silica e bases (seu horizonte $\mathrm{Bt}$ possui mineralogia caulinítica soma de bases, CTC e atividades de argilas bem superiores às encontradas no horizonte $\mathrm{Bt}$ de $\mathrm{P} 7$ ). Feições superficiais com estas características são denominadas por Guerra \& Cunha (1995) como escarpas de falhas e de linha de falhas, caminho preferencial dos movimentos de massa e de erosão hídríca. 
O horizonte A chernozêmico destes solos é muito escuro (cores com croma 3 e valor 2), com teores de matéria orgânica superiores a $31 \mathrm{~g} \mathrm{~kg}^{-1}$ e saturação por bases superiores a $50 \%$. Blocos subangulares pequenos a grandes e moderados a fortes compõem sua estrutura de campo. A observação de amostras indeformadas do horizonte Ap de P7 revelou a presença de agregados poliédicos (blocos) com diâmetro maior que $2 \mathrm{~mm}$, bruno-avermelhados, formados pela cimentação de fragmentos de areia e carvão por material plásmico. É grande a presença de raízes e comum a presença de cascalho de quartzo.

A análise micromorfológica deste horizonte revela uma pedalidade bastante desenvolvida. A trama é preferencialmente porfirítica com plasma de coloração bruno avermelhada-escura, mas pode ser granóidica dentro de alguns biopedotúbulos. Os grãos do esqueleto são constituídos por fragmentos de carvão (5\%) e de quartzo (15\%) com tamanho e forma variados (Figura 43). A porosidade (15\%) é predominantemente fissural, também com orientação SE-NW. Muitos dos poros fissurais estão preenchidos por material plásmico mais claro, possivelmente argilas passíveis de serem eluviadas. Não se verificou a ocorrência isolada de microagregados arredondados.

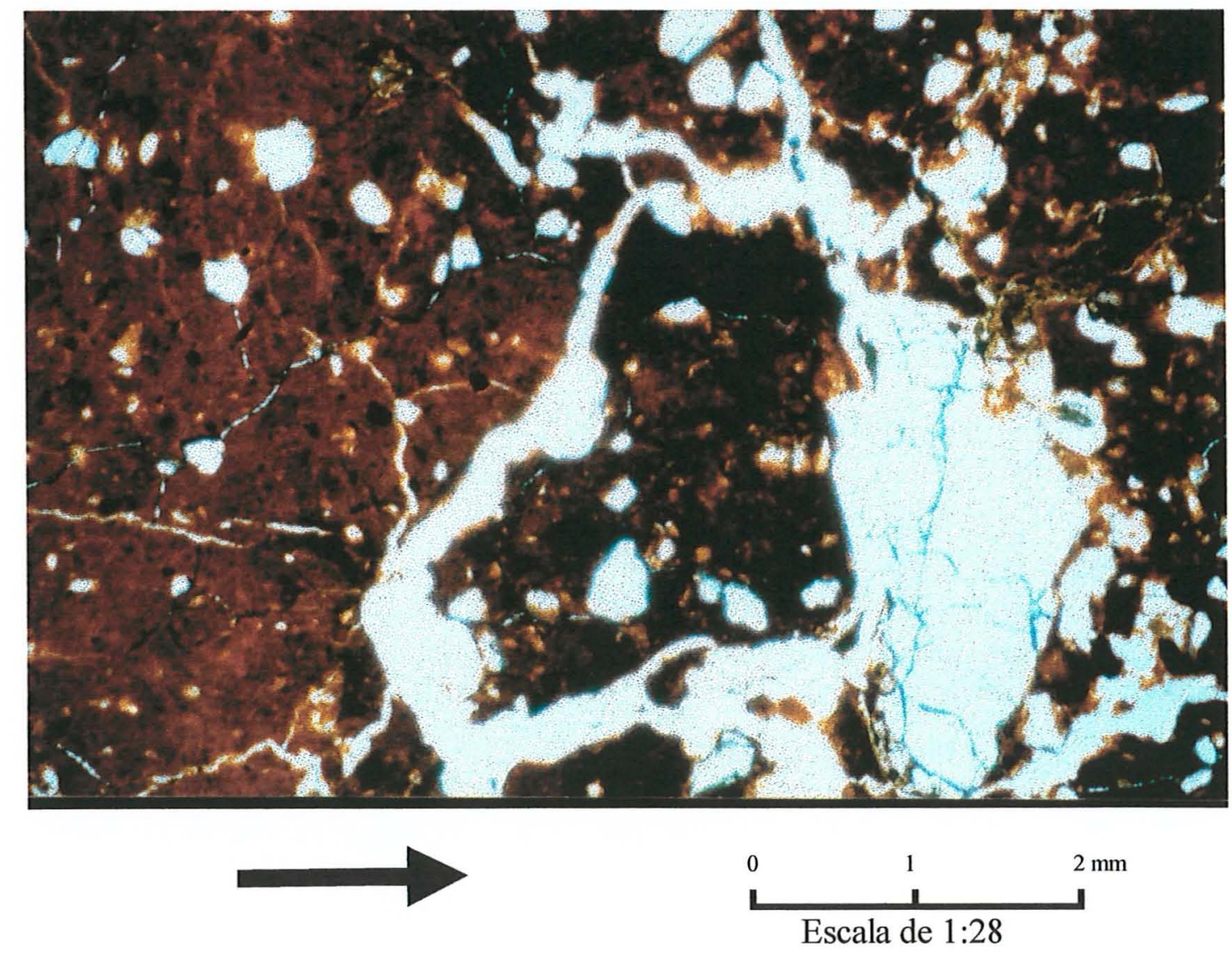

Figura 43. Fotomicrografia do horizonte Ap de P7. Trama porfirítica 
$\mathrm{O}$ horizonte $\mathrm{BA}$ de $\mathrm{P} 7$ apresenta estrutura em blocos subangulares e prismas, fortes e pequenos. Sua consistência é firme e a cerosidade foi descrita como abundante e forte de cor $10 \mathrm{R} 3 / 4$, em um fundo $10 \mathrm{R} 4 / 6$ ou 4/8. Sua Ds é a mais elevada do perfil. A observação acurada de amostras indeformadas em BA revelou o predomínio de agregados com diâmetro maior do que $3 \mathrm{~mm}$, vermelhos, poliédricos, formados por partículas de quartzo de tamanho variado e pouco carvão, cimentados por plasma. Estes agregados encontram-se fissurados e a cerosidade em sua superficie é forte e abundante. Existem poucos microagregados arredondados, vermelhos, de diâmetro menor que $1 \mathrm{~mm}$. Mas eles só ocorrem aderidos aos agregados maiores.

A descrição de lâminas delgadas deste horizonte revelou também uma pedalidade bem desenvolvida. A trama é porfirítica, com ferri-argilãs orientados preenchendo a maior parte dos canais, vesículas, cavidades e fissuras, inclusive coalescendo microagregados ou os cimentando com unidades estruturais maiores. Estes ferriargilãs ocupam cerca de $30 \%$ da área da lâmina (Figuras 44 e 45) e são evidências de forte argiluviação; o que corrobora os trabalhos de Sombroek (1980) e Nettleton et al. (1987).

Nos horizontes superficiais deste perfil ocorre o favorecimento de um mecanismo de dispersão-fluxo-deposição dos finos, relacionado com os mais elevados valores $\mathrm{S}$, com a maior atividade de argilas e com a maior intensidade dos ciclos de umedecimento e secagem, apesar do clima atual (sem estação seca bem definida), não favorecer a argiluviação.

A análise pedografica do horizonte $\mathrm{Bt}$ revela a instalação de processos que levam a latolização de baixo para cima do perfil, semelhantes aos verificados em P6. Apesar deste horizonte ser espesso (4,5 m) a identificação de cerosidade comum e forte, de gnaisses em decomposição de 4 a $20 \mathrm{~cm}$ de diâmetro por toda sua espessura e a constância de seus teores de $\mathrm{Fe}, \mathrm{Ti}, \mathrm{Zr}$ totais e da relação $\mathrm{Ti} / \mathrm{Zr}$, respectivamente, entre 81 e $82 \mathrm{~g} \mathrm{~kg}^{-1}$, entre 4,4 e $4,5 \mathrm{~g} \mathrm{~kg}^{-1}$; entre 280 e $331 \mathrm{mg} \mathrm{kg}^{-1}$ e entre 13,86 e 18,82 , revelam sua homogeneidade. Muitos microagregados arredondados, avermelhados, menores que $2 \mathrm{~mm}$, com esqueleto interno tirado (quartzo e carvão arredondados e arestados), provavelmente zoogenéticos, ocorrem neste horizonte. Também verifica-se a 


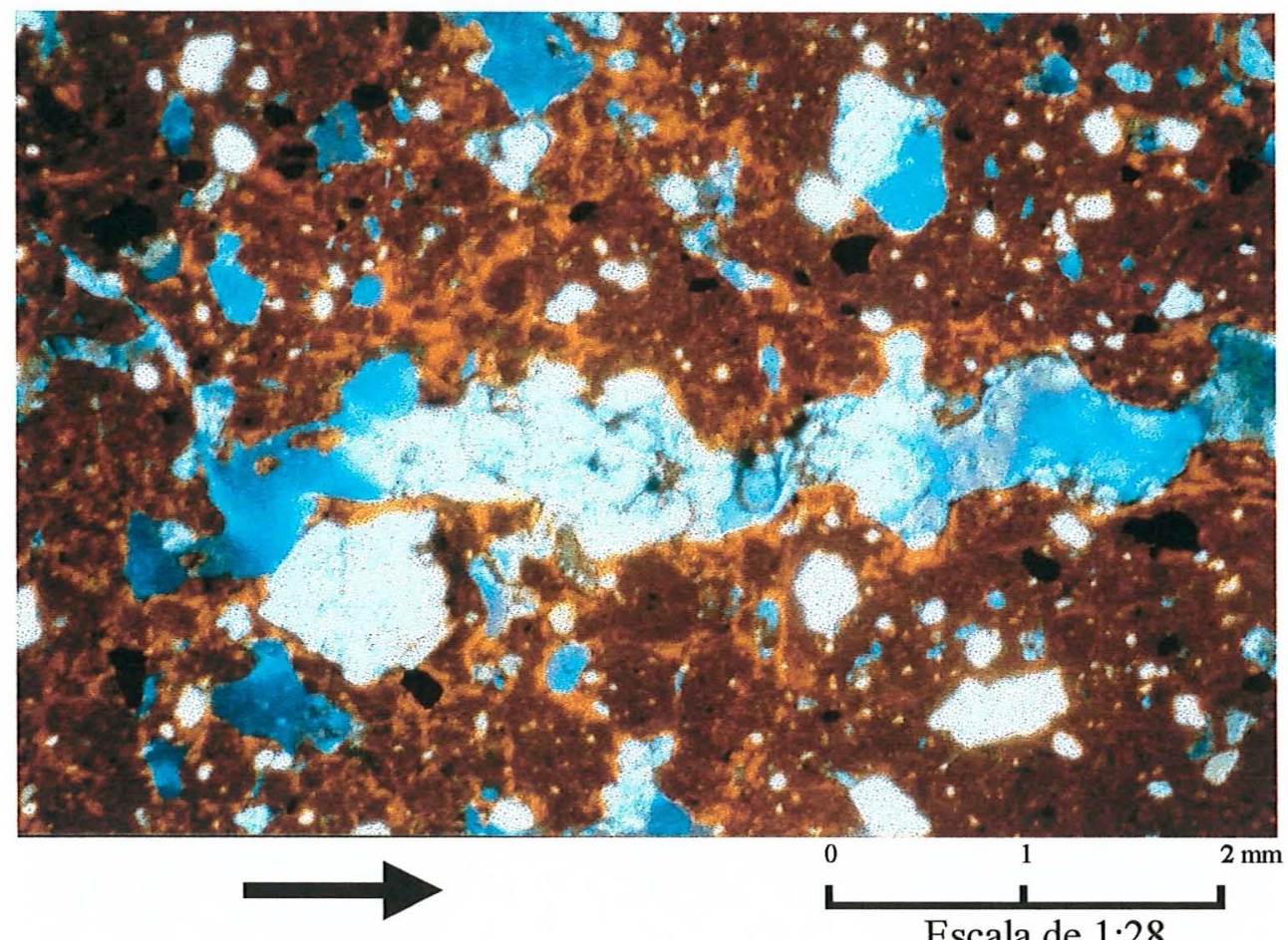

Figura 44. Fotomicrografia sob luz polarizada da transição BA/Bt em P7. Predomínio de cutãs de iluviação.

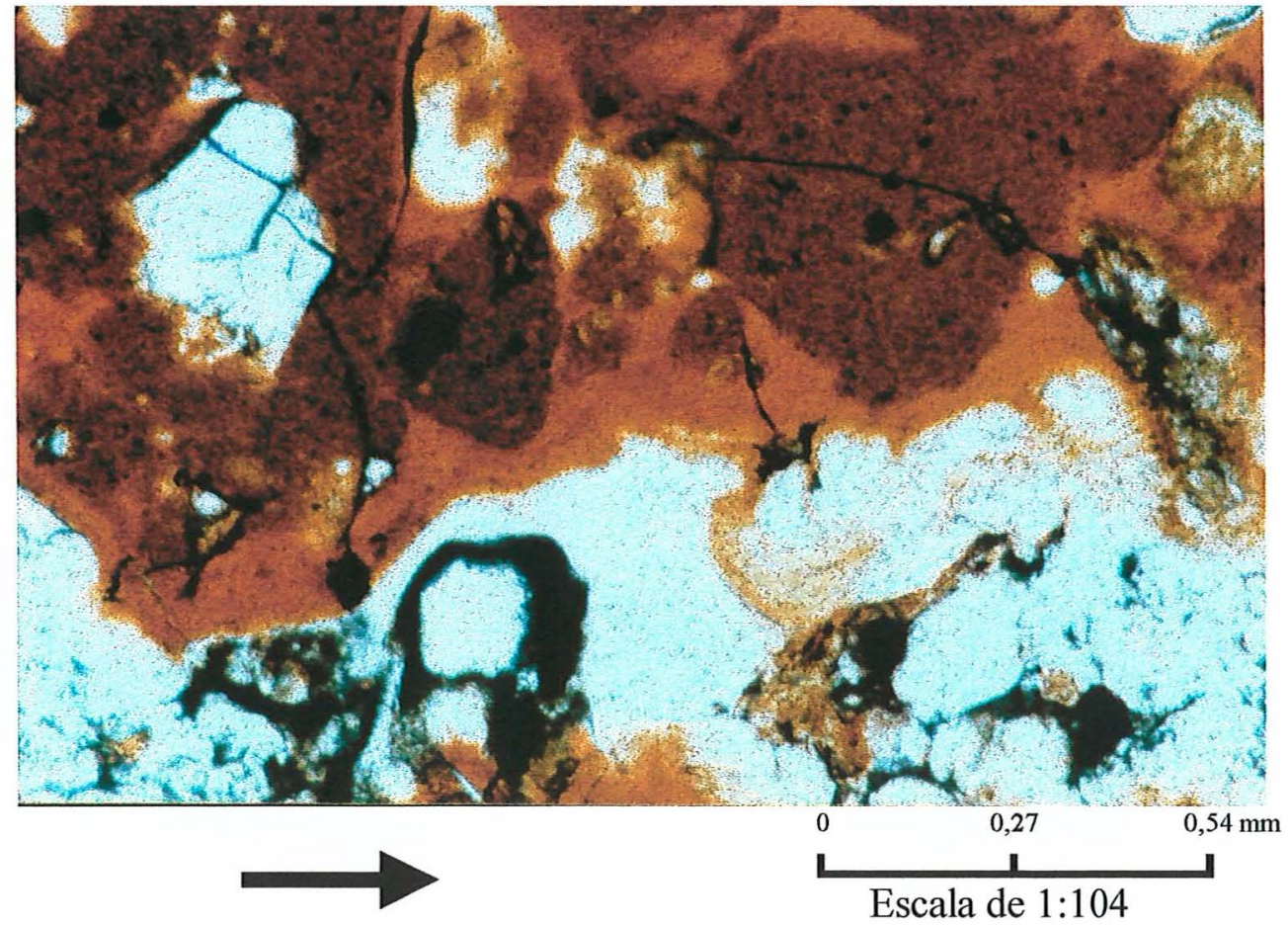

Figura 45. Detalhe dos cutãs de iluviação nas paredes de uma cavidade em BA/Bt 
presença de microagregados de gênese parcialmente geoquímica e complexa. A trama é granóidica e os ferriargilãs não ocorrem de forma orientada, revestindo e preenchendo os poros, mas dispersos na matriz $\mathrm{S}$, na forma de pápulas (Figura 46). A presença de biopedotúbulos é bem mais significativa que em $\mathrm{BA}$ e a estrutura de campo de $\mathrm{Bt}$ foi descrita como moderada, média, em blocos subangulares que se desfazem em grânulos muito fortes e pequenos. Sua densidade também é menor, entre 0,95 e 1,02 $\mathrm{t} \mathrm{m}^{-3}$.

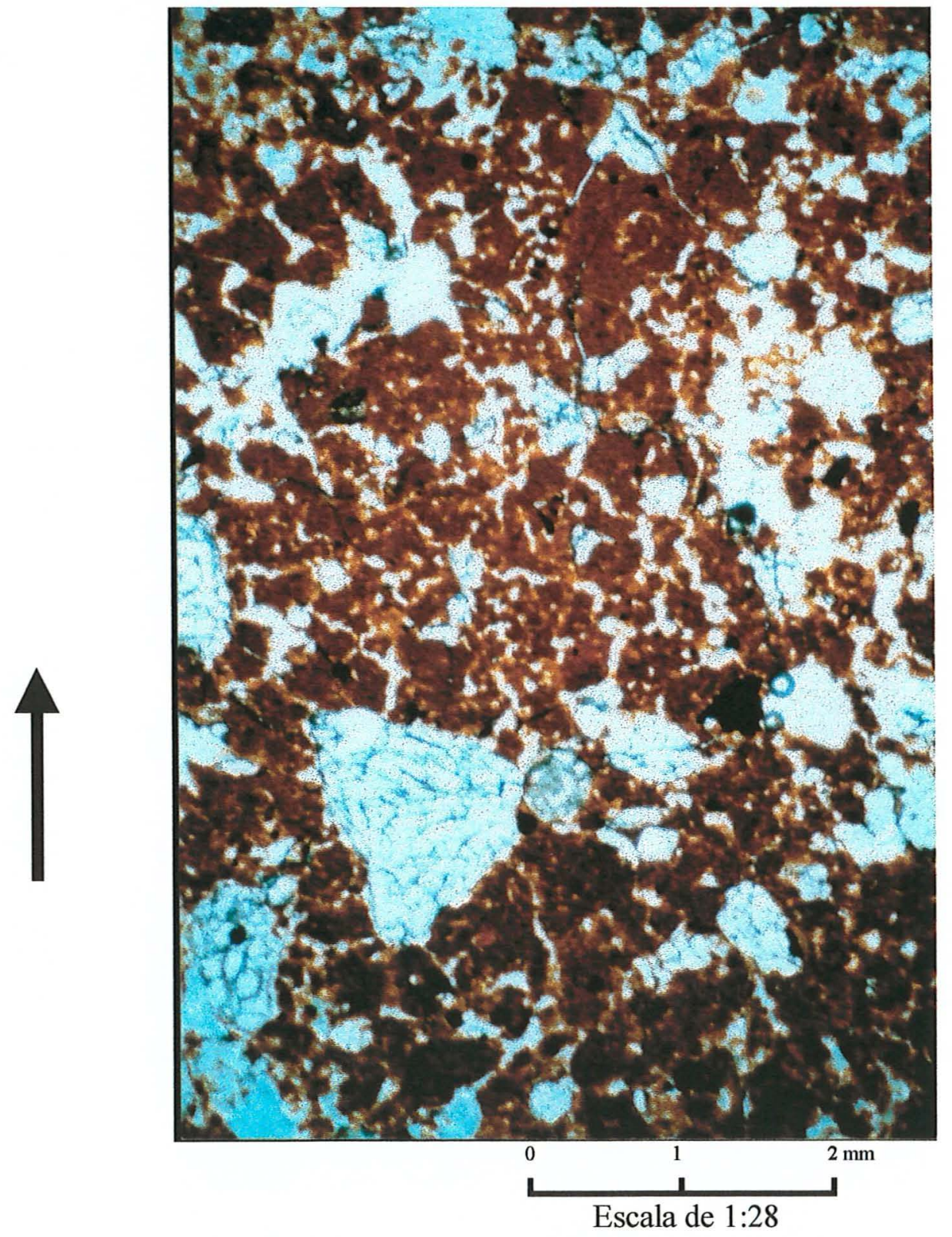

Figura 46. Fotomicrografia do horizonte Bt1 de P7. Trama granóidica 
A latolização de baixo para cima deste solo estaria ocorrendo face ao clima atual ser mais úmido, favorecendo a desferrificação parcial do plasma, que leva a formação de microagregados. A atividade da fauna do solo também é fator preponderante para este processo. O horizonte BA é o que possui o maior valor de Ds do perfil, pois o fluxo lateral subsuperficial de água, nestes segmentos de elevada declividade, causa o adensamento deste horizonte, dificultando a ação de formigas e cupins.

O horizonte $\mathrm{CB}$ deste solo, alcançado a $6,10 \mathrm{~m}$ de profundidade, apresenta teor de Fe total e de Ti total, respectivamente $160 \mathrm{~g} \mathrm{~kg}^{-1}$ e $9,3 \mathrm{~g} \mathrm{~kg}^{-1}$, valores próximos aos encontrados por Radambrasil (1983) para granulitos do Complexo Guaxupé. Feldspatos, mica e ilmenita formam sua fração silte. Suas argilas são cauliníticas, mas também foi detectada a presença de mica, possivelmente herdada do material de origem ( biotitas são minerais comumente encontrados nos charnoquitos) (Apêndice 4).

O horizonte $\mathrm{CB}$ de $\mathrm{P} 2$ (LH) difere significativamente do horizonte $\mathrm{CB}$ de $\mathrm{P} 7$ em cor, granulometria, mineralogia da fração argila, no teor total de alguns elementos e na relação Ti/Zr (Apêndices 1, 2, 3 e 4). Estas diferenças evidenciam a presença de pelo menos dois materiais de origem dos solos, expostos ao intemperismo por períodos de tempo diferentes. A presença de ilmenita na fração silte em $\mathrm{CB}$ de $\mathrm{P} 7$, juntamente com a presença de micas na fração argila, sugerem menor tempo de exposição ao intemperismo.

As considerações do parágrafo anterior fortalecem a hipótese de ocorrência preferencial de movimentos de massa e de erosão hídrica nesta encosta, que causaria constantes rejuvenecimentos do solo. A fertilidade mais elevada de seus solos também é outra evidência desta hipótese.

\subsubsection{Sistema Morfopedológico II (SMII)}

Transseção de $1500 \mathrm{~m}$ de extensão, inicia-se em um nível de base local (riacho) e termina em um nível de base regional, o rio Machado (Figura 6). Corresponde a colinas de topos aplainados e vertentes suavizadas, onde os declives oscilam entre 2 e $22 \%$. Apresenta uma cobertura pedológica latossólica muito argilosa e homogênea. Estes atributos, contrastantes em relação ao SMI, sugerem uma paisagem relativamente 
estabilizada, menos afetada pela tectônica ressurgente. Carmargo et al. (1962) descreve esta superfície como senil, relativamente estabilizada, onde a frente de intemperização das rochas progride gradualmente em profundidade.

Em diversos topos de SMII ocorrem Latossolos Húmicos similares aos encontrados na encosta sudoeste de SMI. De acordo com a interpretação dada anteriormente neste trabalho, esta constatação sugere um período de estabilidade da paisagem, modificada a partir do Terciário Médio, com a reativação neotectônica, que afetou muito mais SMI que SMII, já que SMI localiza-se no contato entre dois complexos geológicos, enquanto SMI encontra-se embasado apenas pelo Complexo Amparo. A instalação da rede de drenagem em SMII pode ser atribuída à erosão hídrica ativada principalmete por intensificação de fenômenos climáticos e secundariamente por movimentos tectônicos residuais como os descritos por Mioto (1990), que persistem até os dias atuais (sismos) e causaram deslizamentos em alguns terços inferiores de encostas.

\section{Perfis 9 e 10 (topo e ombro)}

Nos topos e ombros, onde a declividade varia entre 2 e $15 \%$ ocorrem Latossolo Vermelho-Escuro (P9) e Latossolo Húmico (P10), ambos muito argilosos. A principal diferença entre eles é a espessura do horizonte A. Ambos solos são muito profundos, permeáveis e homogêneos, com matizes 2,5 YR e transição difusa entre horizontes e subhorizontes. A atividade biológica é intensa nos perfis, comprovada pela presença de inúmeros biopedotúbulos. Em P9 os fragmentos de carvão são esparsos e menores que $20 \mathrm{~mm}$ de diâmetro. Em P10 estes fragmentos são comuns e menores que $15 \mathrm{~mm}$, com exceção dos encontrados a $1,17 \mathrm{~m}$ de profundidade, que atingem até $60 \mathrm{~mm}$.

Estes perfis apresentam homogeneidade em profundidade e entre si, em relação a distribuição das areias (Figura 28) e em relação a parâmetros químicos ( $\mathrm{pH}, \mathrm{CTC}$, valor $\mathrm{S}, \mathrm{V} \%, \mathrm{~m} \%$ e teor de matéria orgânica, apresentados no Apêndice 3. Os teores de $\mathrm{Fe}$ total, Ti total, $\mathrm{Zr}$ total e relação $\mathrm{Ti} / \mathrm{Zr}$ (Apêndice 4), a mineralogia da fração argila (caulinítico-gibbsítica) e da fração silte (feldspatos e mica), também são iguais, assim como muitos dos atributos morfológicos e micromorfológicos. Esta homogeneidade 
comprova que P9 e P10 foram formados a partir do mesmo material (gnaisses e migmatitos do Complexo Amparo).

O horizonte A destes solos ( proeminente em P9 e húmico em P10) é escuro (croma 3 e valor 2), com teores de matéria orgânica acima de $21 \mathrm{~g} \mathrm{~kg}^{-1} . \mathrm{O} \mathrm{pH}$ é ácido a CTC e valor $S$ oscilam, respectivamente, entre 5,9 e 11,7 e entre 1,4 e $2,1 \mathrm{cmol}_{c} \mathrm{~kg}^{-1}$ (fora o horizonte Ap), suas densidades do solo variam de 0,93 a $1,06 \mathrm{t} \mathrm{m}^{-3}$ e sendo mais baixas em P10 (Apêndice 2).A distribuição das areias é semelhante, assim como a granulometria. A exceção fica por conta do horizone Ap de P10, com menor teor de argila em relação ao Ap de P9. Seus teores de Fe total, Ti total, $\mathrm{Zr}$ total e a relação de $\mathrm{Ti} / \mathrm{Zr}$ são, respectivamente $107 \mathrm{~g} \mathrm{~kg}^{-1}$, estão entre 13,3 e $14 \mathrm{~g} \mathrm{~kg}^{-1}$, entre 664 e $749 \mathrm{mg}$ $\mathrm{kg}^{-1}$ e entre 17,82 e 20,48 (Figura 48). A mineralogia da fração argila de ambas é caulinítico-gibbisítica e a fração silte é composta de quartzo, feldspatos e micas (Apêndice 4). A estrutura é formada por grânulos pequenos e muito fortes e blocos subangulares médios e fracos .

Analisando-se estes atributos em conjunto com a análise estrutural (Figura 6) pode-se inferir que em P9 parte do horizonte A foi removido, enquanto que em P10 o mesmo foi preservado.

A análise de amostras indeformadas destes horizontes superficiais, com auxilio da lupa, revela o predomínio de microagregados arredondados, bruno-escuros e de diâmetro menor que $0,1 \mathrm{~mm}$ que, quando associados a fragmentos de quartzo (hialino, leitoso e amarelo), formam agregados maiores que $1 \mathrm{~mm}$ de diâmetro, predominantemente arredondados e de cores escuras. Os microagregados de origem biológica são maiores, mais escuros e mais arredondados que os demais. Sua superficie é lisa e brilhante. É comum a presença de raízes finas e muito finas, nas quais estão aderidos microagregados muito pequenos, fragmentos de carvão e de quartzo. É grande a porosidade dentro e entre os microagregados maiores.

A descrição de lâminas delgadas (Figura 47) confirma muitas informações obtidas através da análise tridimensional de amostras indeformadas. A pedalidade é bem desenvolvida e a trama é predominantemente granóidica, encontrando-se também trama porfiritica nos agregados de origem biológica de tamanho entre 1 e $2 \mathrm{~mm}$. O plasma é 


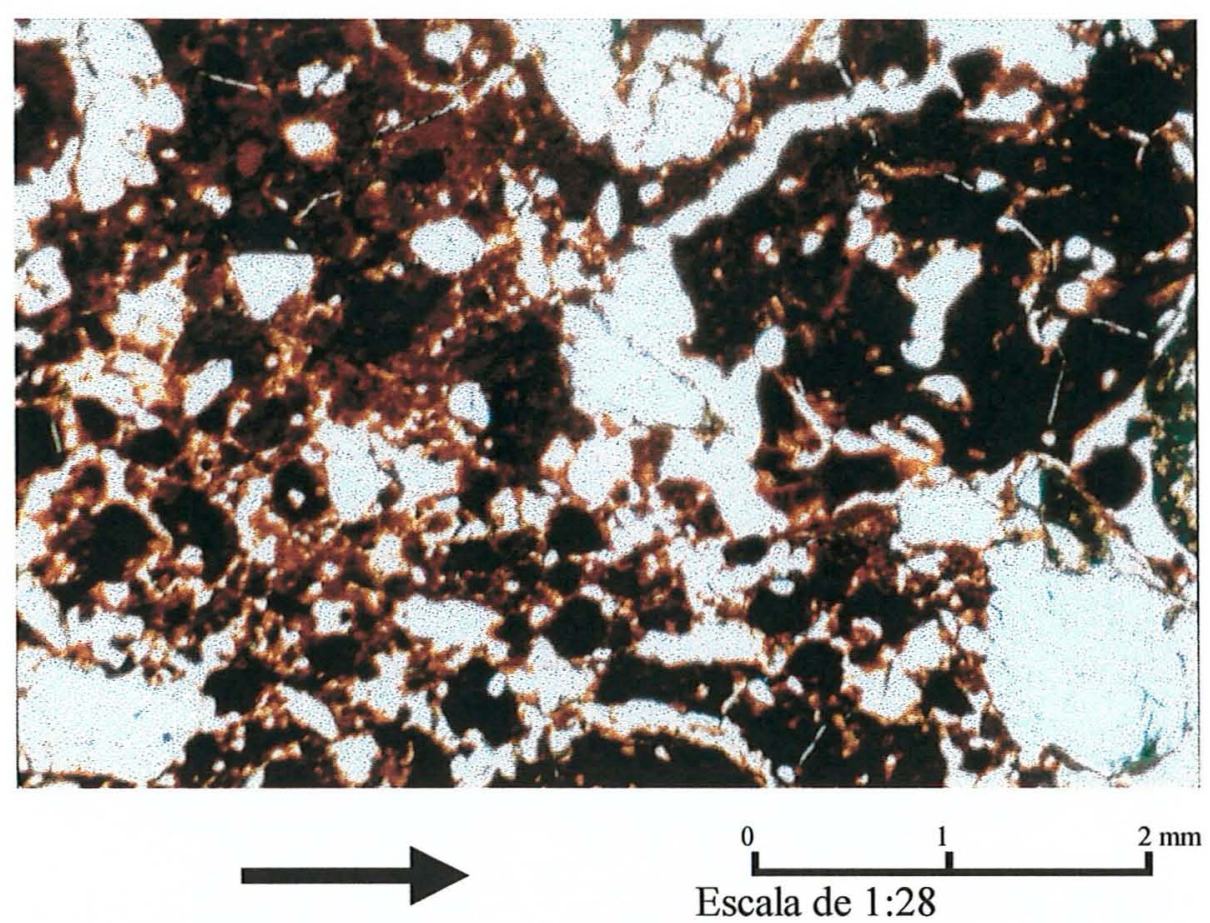

Figura 47. Fotomicrografia do horizonte Ap de P9. Trama granóidica

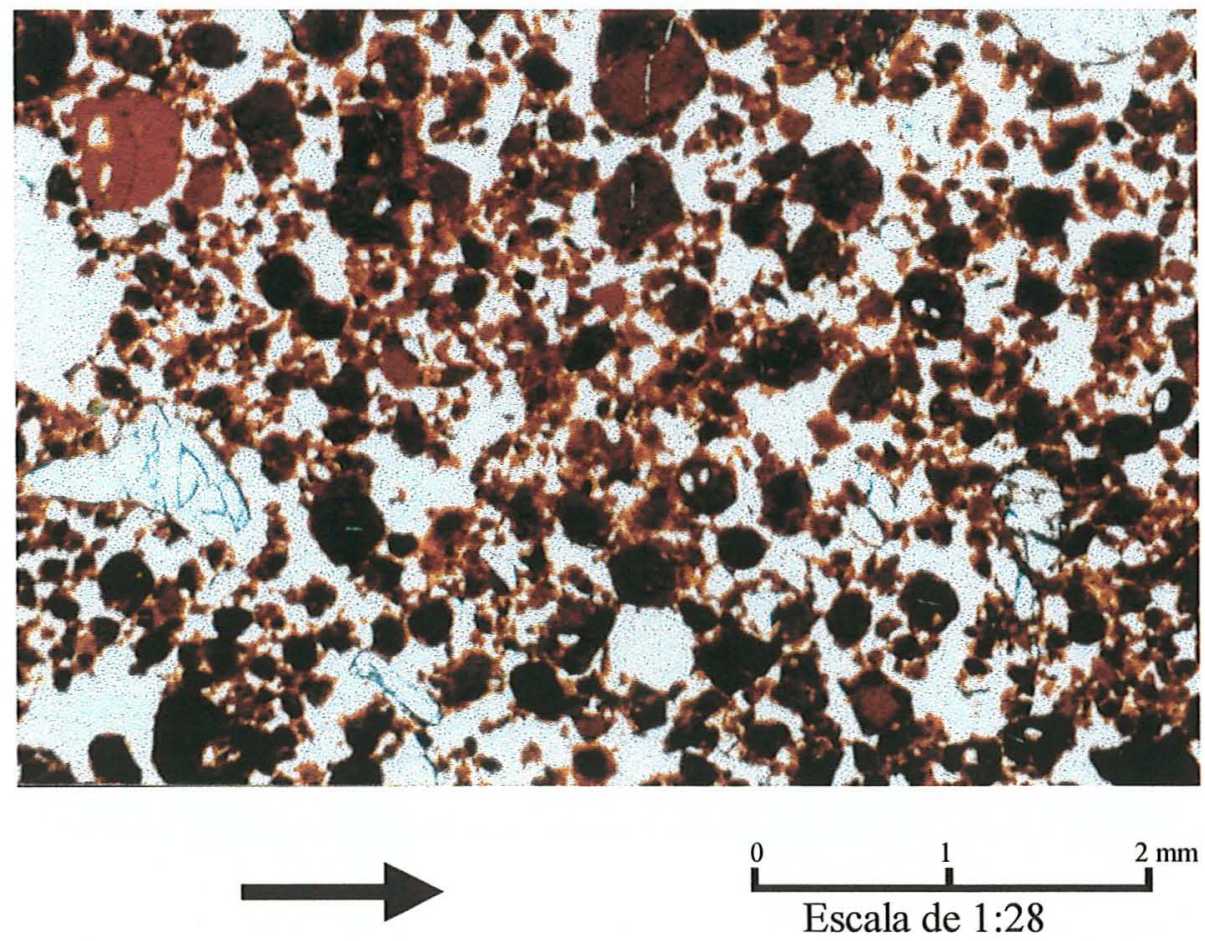

Figura 49. Fotomicrografia do horizonte Bw de P10.Trama grânica-granóidica 

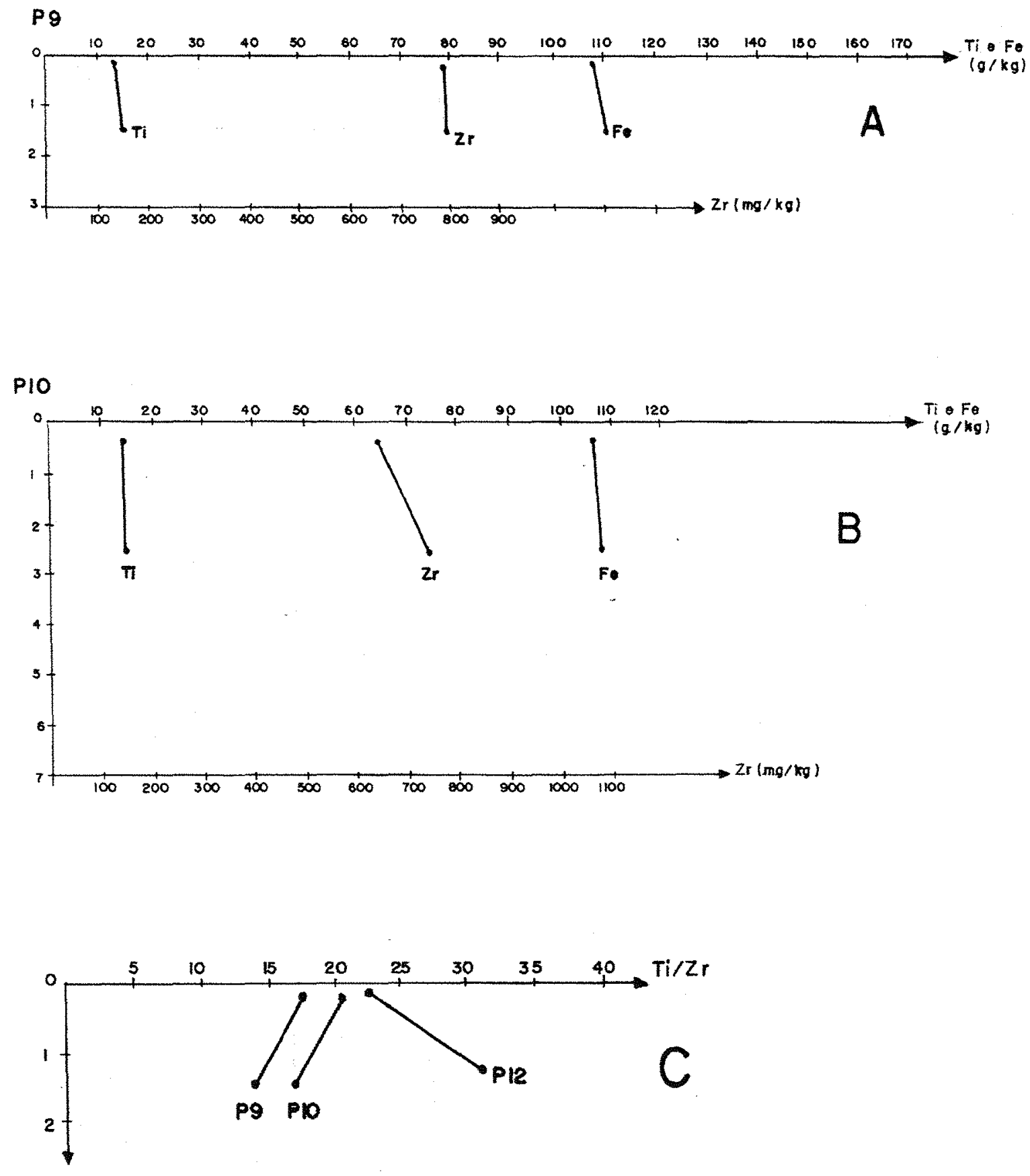

Figura 49. Teorers de Ti, Fe e Zr em P9 (A), P (10) (b) e relação Ti/Zr em P9, P10 e P12 
bruno-escuro. O esqueleto é formado por fragmentos de carvão (2\%) e quartzo (12\%), de tamanhos e formas variadas. A porosidade dominante é formada por canais e cavidades, mas também ocorrem poros mamelonares e onde a trama é porfiritica a porosidade é fissural. Os poros ocupam $40 \%$ da área da lâmina. As partes do plasma que são de coloração vermelha correspondem a microagregados de origem biológica (arredondados e com esqueleto interno triado), remontados a partir do horizonte Bw. A fissuração dos agregados maiores sugere sua destruição, pois situam-se próximos à superficie, onde o ressecamento do solo é mais intenso, causando a contração das argilas. Microagregados complexos também ocorrem nestes horizontes.

O horizonte subsuperficial de P9 e P10 apresenta atributos de um Bw típico. A CTC, o valor $\mathrm{S}, \mathrm{V} \%$ e m\% são baixos (Apêndice 3). Suas argilas são cauliniticogibbsíticas e sua estrutura é muito forte, muito pequena, granular. A porosidade é abundante e os poros são de tamanho variado, o que é corroborado pela densidade do solo, que varia de $0,80 \mathrm{a} 0,96 \mathrm{t} \mathrm{m}^{3}$ e é a menor dentre os solos estudados (Apêndice 2). A atividade da fauna do solo também é intensa neste perfil. Os teores de $\mathrm{Fe}$, Ti e $\mathrm{Zr}$ totais, bem como a relação Ti/Zr são similares aos encontrados para o horizonte A destes solos ( Figura 48).

A descrição de amostras indeformadas no laboratório revela o predomínio de microagregados arredondados, formados unicamente de material plásmico, vermelhos ou bruno avermelhados, de diâmetro menor que $0,05 \mathrm{~mm}$, ocorrendo isolados ou associados a outros microagregados escuros, brilhantes e arredondados, a fragmentos de quartzo e carvão, formando agregados maiores que $1 \mathrm{~mm}$ de acordo com o esquema da Figura 31. É grande a porosidade entre os microagregados e dentro dos agregados maiores. Raízes finas são pouco comuns.

Analisando-se as lâminas delgadas de Bw destes perfis (Figura 49) verifica-se uma pedalidade muito bem desenvolvida. A trama é grânica a grânica-granóidica e o plasma é predominantemente vermelho, mas ocorrem partes bruno-avermelhadas. $\mathrm{O}$ esqueleto é constituído por partículas de quartzo (12\%) e fragmentos de carvão (1\%), ambos de tamanhos e formas variadas. A porosidade é de empilhamento, mas também ocorrem cavidades de origem biológica e fissuras nos microagregados maiores. 
Microagregados arredondados, de tamanho entre 0,5 e $0,01 \mathrm{~mm}$ predominam neste horizonte. A gênese dos mesmos pode ser atribuida a diferentes processos: a ação da fauna do solo, a geoquímica e a microestruturação. Os microagregados maiores são zoogenéticos, pois são arredondados, bruno avermelhados e apresentam esqueleto interno triado (Miklós, 1993). A maioria deles está se fissurando, o que leva a formação de microagregados ainda menores por microestruturação. Muitos dos outros microagregados maiores estão sendo parcialmente desferrificados. A Figura 49 mostra partes do plasma amareladas, transicionando para as partes onde o plasma é vermelho, originadas possivelmente por desferrificação parcial, formando protótipos de microagregados de acordo com o modelo proposto por Chauvel (1978) citado por Stoops (1983). Este processo causa a formação de microagregados de tamanho menor que $0,05 \mathrm{~mm}$. As partes brunadas do plasma provavelmente podem ser matéria orgânica que em maior quantidade causa a melanização. Uma das fontes desta matéria orgânica (ácidos húmicos, fúlvicos, hematomelânicos e humina) é o carvão. Estes detalhes também podem ser observados na Figura 50 e serão discutidos no próximo capítulo.

As informações contidas no parágrafo anterior contribuem para o estabelecimento de um modelo atual de microestruturação do horizonte Bw de P9 e P10. Este modelo preconiza uma pré-formação de microagregados zoogenéticos com tamanho entre 1 e $0,1 \mathrm{~mm}$, que estão sendo transformados por processos físico-químicos em microagregados ainda menores, de tamanho inferior a $0,05 \mathrm{~mm}$. Desta forma, pode-se inferir que houve um período no qual a atividade biológica era mais intensa do que a atual. Os canais com até $6 \mathrm{~cm}$ de diâmetro,comumente encontrados, provavelmente não foram escavados nestes tempos, pois não existem espécies de cupins e formigas na atual do fauna do solo com tal capacidade e as características destes canais (paredes polidas) são típicas destes insetos.

\section{Perfil P11 (meia-encosta)}

A $230 \mathrm{~m}$ de P10, na meia encosta, onde a declividade oscila entre 15 e $22 \%$, foi descrito Latossolo Vermelho-Escuro, distrófico, A moderado, textura muito argilosa (P11). Muitas das propriedades e características destes solos se assemelham às 

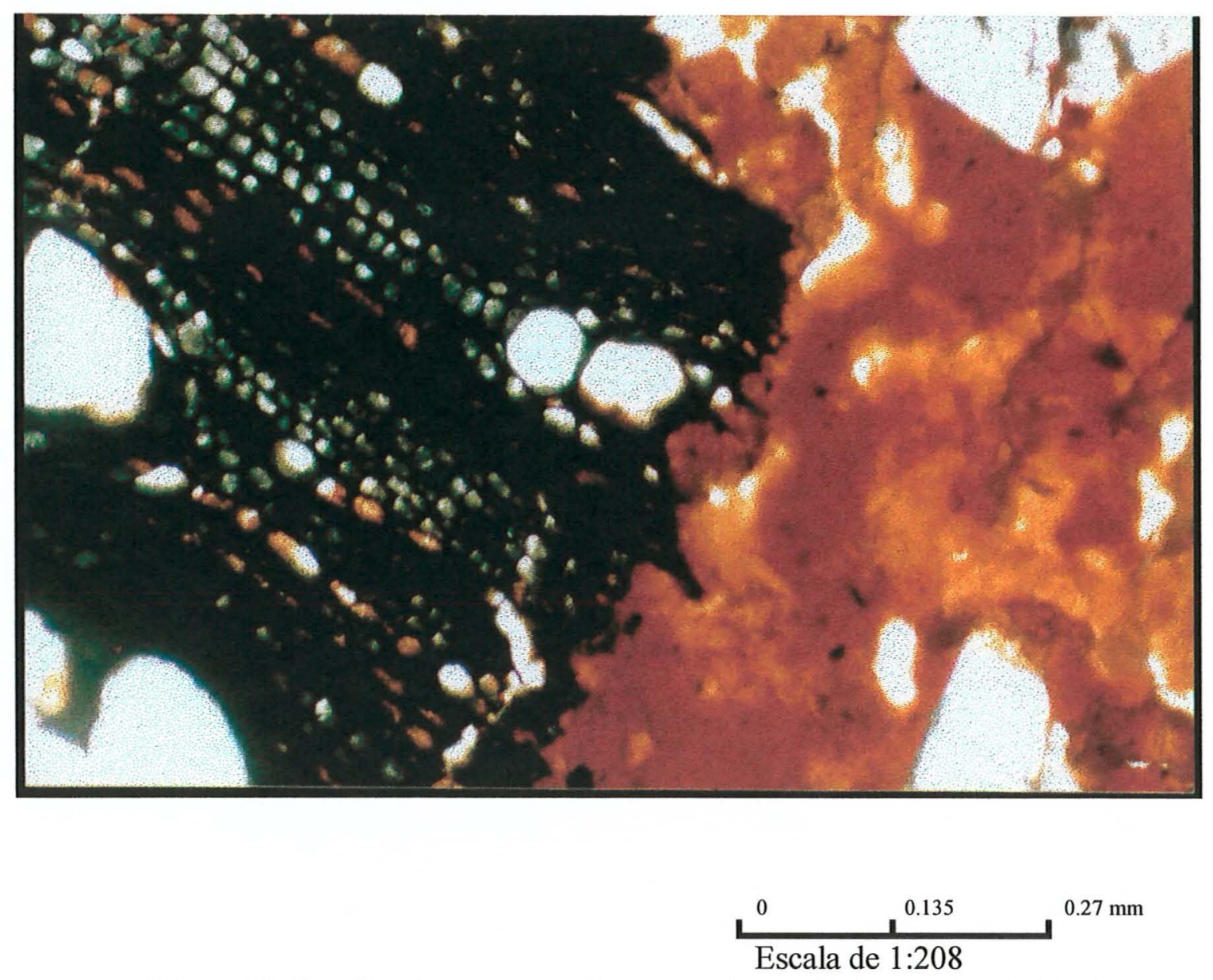

Figura 50. Detalhe do carvão se decompondo no horizonte Ap de P9. As partes brunadas do plasma contrastam com as cores dominantes

encontradas para os latossolos do topo (P9 e P10). A textura, os atributos químicos, a mineralogia das frações silte e argila, as feições micromorfológicas, a estrutura e a cor horizonte Bw são similares. Já a densidade do solo, a cor e espessura do horizonte A e a distribuição de areias são contrastantes (Apêndices 1, 2 e 5 ). Estas observações analisas em conjunto balisam a hipótese da cobertura pedológica ser originada do mesmo material fonte, retrabalhado, mas que também apresenta propriedades influencidas pela dinâmica de encostas, levada a cabo pelo fluxo lateral subsuperficial da água no solo e pelo transporte a curta distância. Os baixos valores de CTC e de soma de bases obtidos para todos os perfis atestam a homogeneidade do material, advinda de seu intenso retrabalhamento. 
O horizonte A de $\mathrm{P} 11$ possui cores mais claras e menor espessura em relação aos solos de topo (Figura 6). Sua estrutura é mais desenvolvida, composta por blocos subangulares moderados e médios e grânulos e sua textura é semelhante a encontrada no horizonte A2 de P10 (Apêndice 1). Seus teores de Fe total e Ti total são um pouco menores, mas a relação Ti/Zr é semelhante (Apêndice 4). Estas observações sugerem o recuo de encostas por erosão hídrica, ativada por fenômenos climáticos, removendo parte deste horizonte, expondo camadas mais profundas à superfície, provocando o reinício de formação do horizonte A.

O exame das amostras indeformadas ampliadas revelou um predomínio de agregados poliédricos maiores que $2 \mathrm{~mm}$, formados pela coalescência de microagregados plásmicos arredondados com microagregados de origem biológica e fragmentos de areia e carvão. A descrição de lâminas delgadas confirma estas observações. A trama é predominantemente porfirítica com um denso plasma bruno-avermelhado (Figura 51). O esqueleto é formado por partículas de quartzo (30\%) e de fragmentos de carvão (4\%) de tamanhos e formas variadas. A porosidade é predominantemente fissural, mas também ocorrem canais e cavidades de origem biológica. Estas características validam a hipótese da remoção de parte do horizonte A nesta posição de encosta, expondo camadas subsuperficiais, adensadas pelo fluxo lateral subsuperficial, a processos pedogenéticos de formação de camadas superficiais, processos estes ainda incipientes em relação aos dos solos do topo.

Os horizontes de transição $\mathrm{AB}$ e $\mathrm{BA}$ apresentam estrutura em blocos e maior densidade de solo em relação a todos os horizontes dos solos do topo, possivelmente pela ação do fluxo lateral subsuperficial da água no solo. Este fluxo se inicia, de acordo com o modelo proposto por Moniz \& Buol (1982), com a mudança do nível de base local, causado por dissecação por erosão hídrica ou por movimentos tectônicos e os horizontes próximos à superfície começam a sofrer comprensão devido a ciclos alternados de saturação e dissecação. Esta compressão causa o adensamento do solo e a formação de estrutura em blocos, mas não é suficiente para caracterizar um horizonte B textural, pois o gradiente textural é baixo e não existem evidências de argiluviação. 


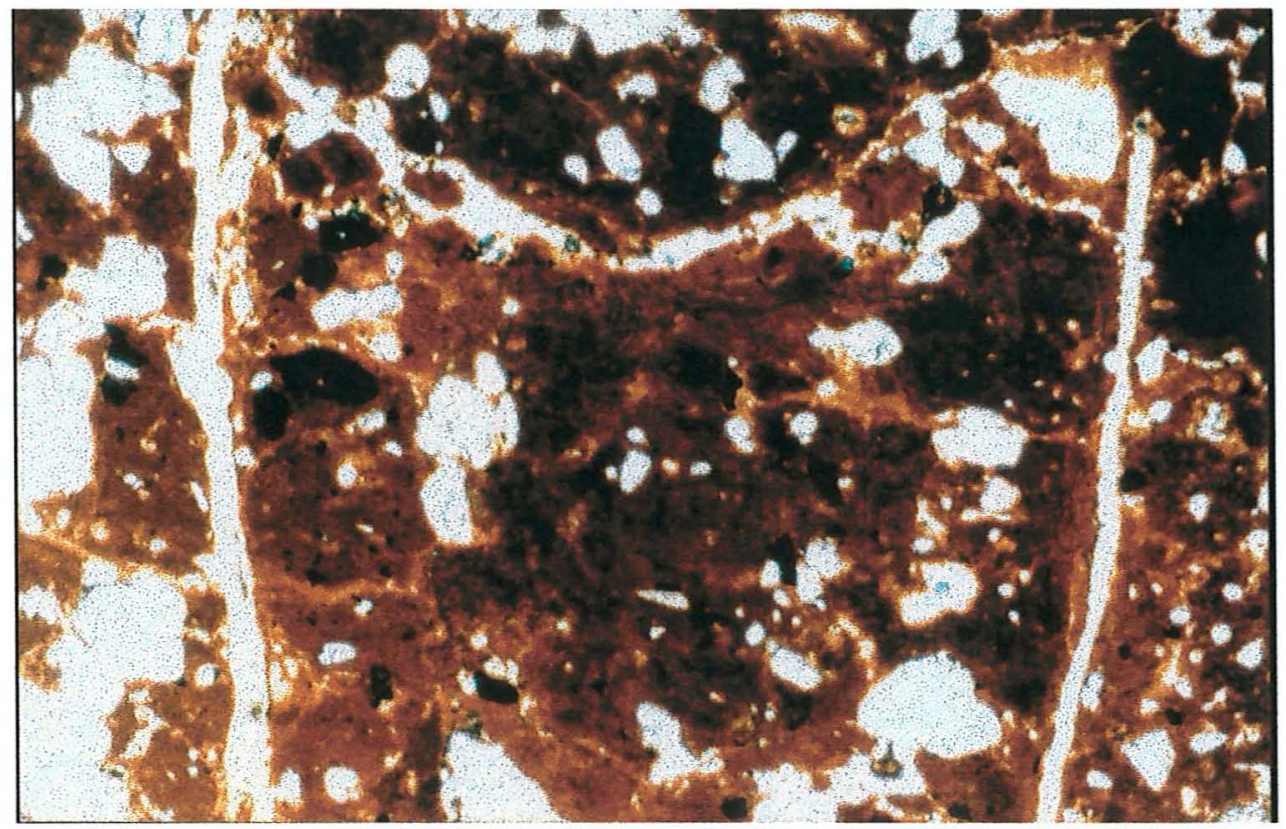

Figura 51. Fotomicrografia do horizonte Ap de P11 Trama porfirítica.

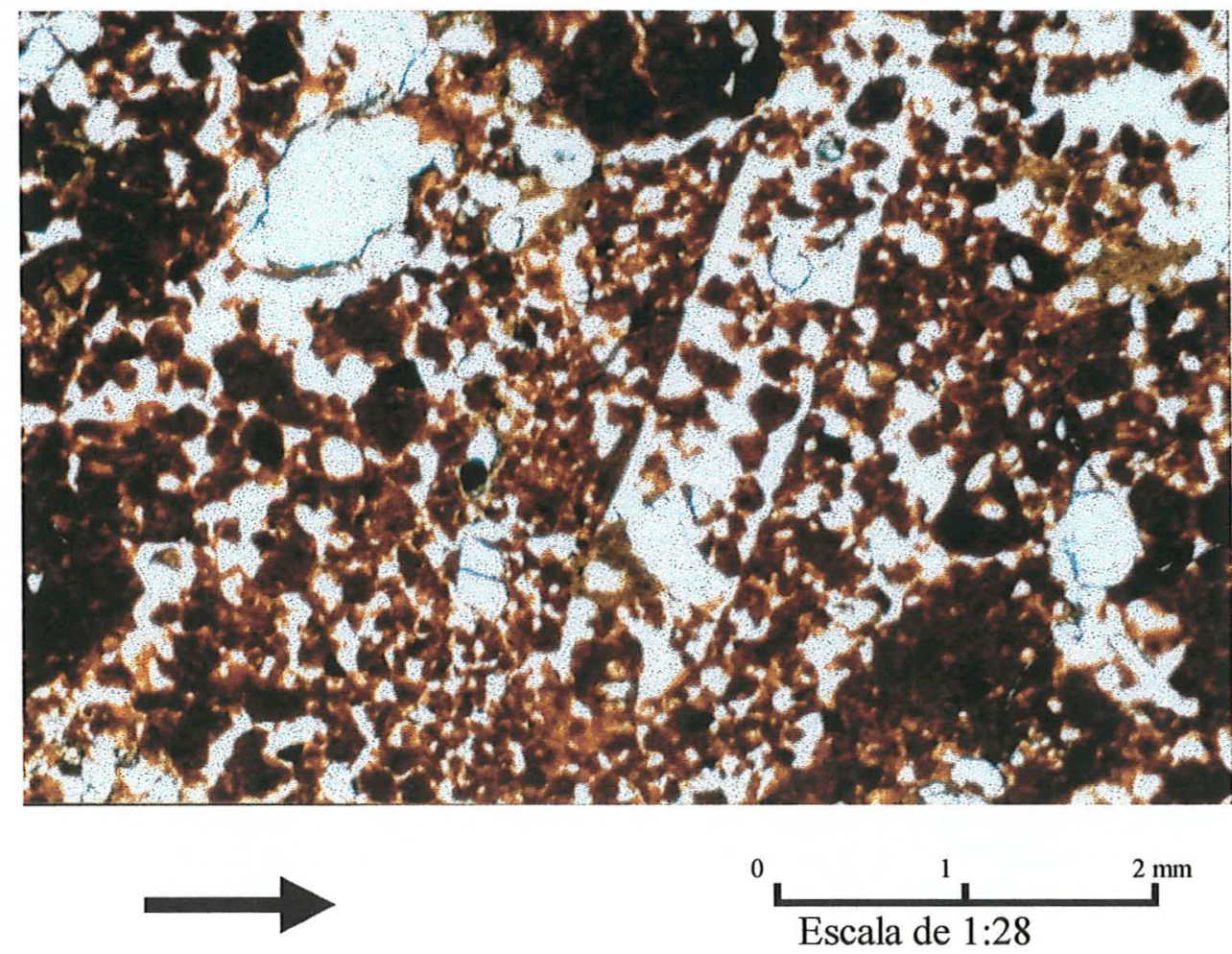

Figura 52. Fotomicrografia do horizonte Bw de P11 Trama granóidica. 
O horizonte $\mathrm{Bw}$ localizado abaixo de $1,0 \mathrm{~m}$, é menos influenciado pelo fluxo lateral e mantém semelhante estrutura e microestrutura em relação aos solos do topo. A estrutura granular descrita no campo é corroborada pela descrição das amostras indeformadas e pela trama granóidica, com porosidade de empilhamento (Figura 52). Observa-se também o predomínio de microagregados arredondados avermelhados e de tamanho entre 0,5 e $0,1 \mathrm{~mm}$ de diâmetro, originados por zoogênese, microestruturação e por geoquímica.

O tamanho médio das areias cresce do topo em direção ao sopé e diminui novamente no terraço fluvial (Apêndice 5). Este incremento sugere carreamento das partículas de areia a partir da transição ombro/meia encosta e sua deposição selecionada encosta abaixo, sendo as mais grossas depositadas no sopé e as mais finas no dique marginal, à medida que o deflúvio superficial vai perdendo energia.

\section{Perfil P12 (sopé)}

O perfil descrito no sopé côncavo desta encosta, onde os declives variam de 12 a $3 \%$ é o mais influenciado pelo processos de dissecação da paisagem e de adensamento do topo do horizonte B. Foi classificado como Latossolo Vermelho Amarelo Podzólico distrófico A moderado textura argilosa/ muito argilosa (P12). É semelhante a P9, P10 e P11 em atributos químicos e mineralógicos mas é o solo mais amarelado de SMII, sugerindo ambiente mais úmido, o que favoreceria a formação de goethitas no sistema goethita/ hematita , como proposto por Resende, 1976; Curi, 1983; Curi \& Franzmeier, 1984; Macedo \& Bryant, 1987), isto devido a maior proximidade do lençol freático com a superficie do terreno, dada pela presença de um nível de base local e outro regional a poucos metros de distância. A ascensão capilar e o fluxo lateral superficial mantém elevada a umidade ao longo do perfil.

Seu gradiente textural também elevado $(1,56)$, é o maior dentre os solos estudados, assim como o tamanho médio das areias ( Apêndices 2 e 5). O gradiente pode ter sido incrementado pela deposição de partículas mais grosseiras de areia nesta posição da encosta. Outra evidência de coluvionamento de material a partir do topo é o aumento 
da relação Ti/Zr com a profundidade em P12 (Figura 48). Este incremento está fora do intervalo calculado por Dress \& Wilding (1973), para caracterizar homogeneidade de materiais.

As análises macromorfológicas e micromorfológicas deste perfil não detectaram evidências de argiluviação, como cerosidade ou presença de cutãs de iluviação. Os horizontes $\mathrm{BA} \mathrm{e} \mathrm{Bw}$ apresentam estrutura microagregada formada por pequenos grânulos muito fortes e nenhuma cerosidade. A atividade biológica é grande ao longo do perfil, onde são encontrados esparsos fragmentos de carvão. A análise das amostras indeformadas no escritório revela a presença de microagregados arredondados de material fino, brunados, menores que $0,05 \mathrm{~mm}$ de diâmetro se coalescendo e se reunindo também a partículas de areia predominantemente arredondadas e a fragmentos de carvão de tamanho e forma variadas para formar agregados maiores que $2 \mathrm{~mm}$ de diâmetro no horizonte A e menores que $1 \mathrm{~mm}$ de diâmetro em Bw. A porosidade é grande entre e dentro dos agregados maiores.

A descrição das lâminas delgadas revela uma trama grânica dominante no horizonte A com esqueleto formado por partículas de quartzo (40\%) e fragmentos de carvão (1\%), com porosidade cavitária, que ocupa $50 \%$ da lâmina. No horizonte $\mathrm{Bw}$, a trama é granóidica, com fases porfiríticas. $O$ esqueleto é semelhante ao encontrado em $\mathrm{A}$, mas ocorre em menor quantidade (20\%). A porosidade é cavitária, mas poros fissurais são observados na fase porfirítica da trama (Figura 53). Os microagregados dominam a matriz e sua gênese é semelhante à descrita para os que ocorrem no horizonte Bw de $\mathrm{P} 9$, P10 e P11.

O aumento do gradiente textural, a elevação do diâmetro médio das areias e a diminuição da espessura a partir do topo até o sopé de SMII, juntamente com o significativo aumento da relação $\mathrm{Ti} / \mathrm{Zr}$ com a profundidade em $\mathrm{P} 12$, caracterizam o coluvionamento de material encosta abaixo, com deposição selecionada de partículas. Esta seleção fornece indícios para caracterizar o predomínio da erosão hídrica na dissecação de encostas de SMII a partir do Plioceno, degradando materiais das partes mais declivosas e depositando no sopé, causando o recuo paralelo de encostas. 


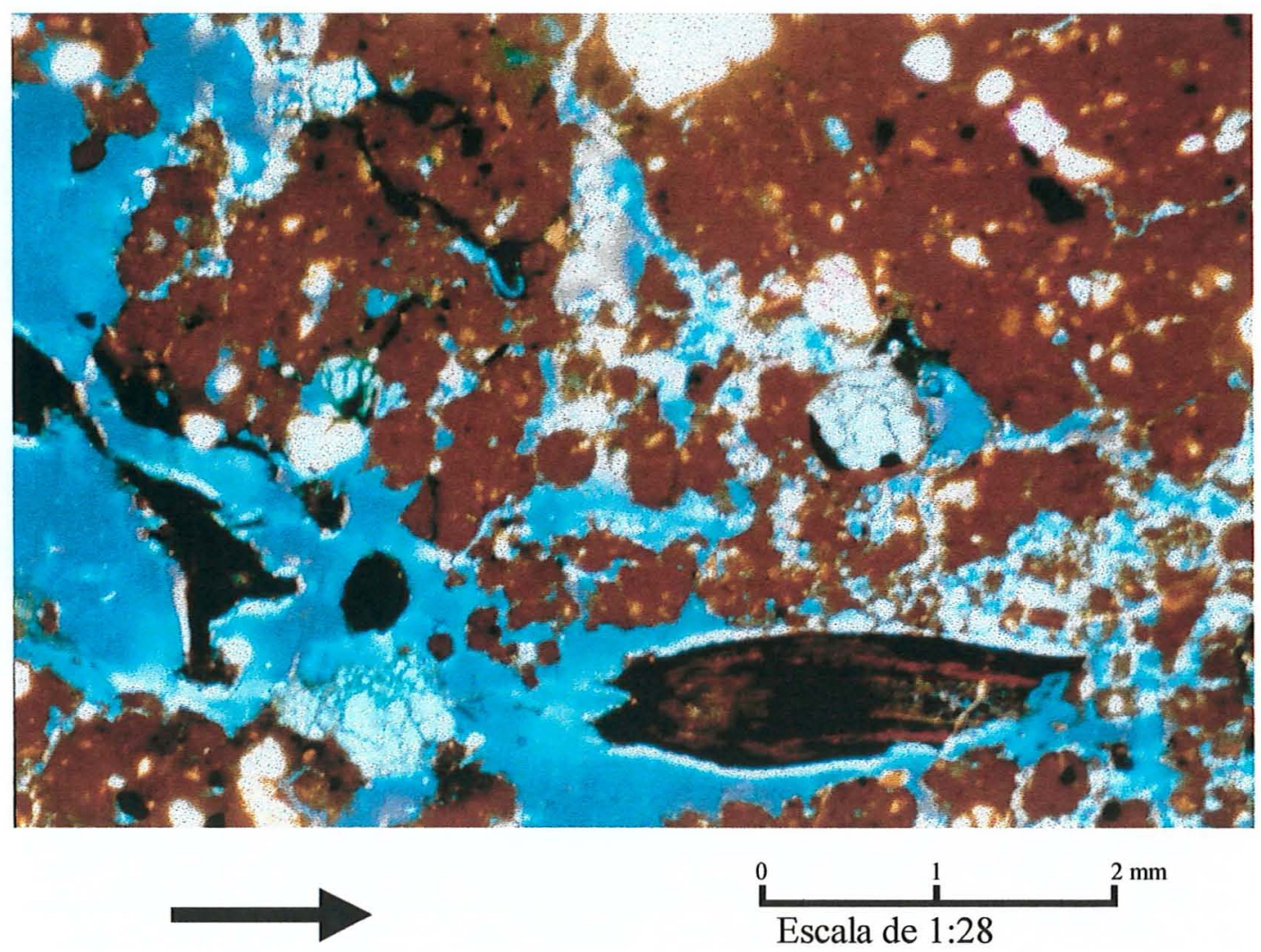

Figura 53. Fotomicrografia do horizonte $\mathrm{Bw}$ de P12. Trama granóidica e porfirítica.

Porém, deslizamentos nos terços inferiores de várias encostas testemunham a ação secundária da tectônica ressurgente neste sistema morfopedológico, dada pelo acomodamento final dos blocos movidos no Terciário, evidenciado pelos abalos sísmicos registrados na região. Nestes locais o declive muda abruptamente, formando taludes com até $45 \%$ de declividade e $50 \mathrm{~m}$ de extensão, onde é comum a presença de terracetes. A cobertura pedológica é a mesma do sopé da encosta, ou seja, Latossolo Vermelho Amarelo Podzólico. O transporte de materiais pedológicos, neste caso, não é seletivo, é mais rápido (movimento de massa) e é posterior ao período mais crítico da erosão hídrica, já que deslizamentos nesta posição da encosta, preconizam uma dissecação anterior da paisagem. 
Analisando-se comparativamente os Latossolos Húmicos dos dois sistemas Morfopedológicos, verifica-se que muitos dos processos pedogenéticos que atuaram na formação dos mesmos são coincidentes. Porém, se deram a partir de materiais de origem diferentes. Provavelmente estes solos correspondem a antigos ciclos de latolização, possivelmente iniciado no Mioceno Superior.

Muitos dos atributos do horizonte A são semelhantes para os latossolos húmicos de SMI e SMII, sugerindo que as causas que levaram à formação deste horizonte espesso e escuro predominaram na paisagem regional por um período grande de tempo, provavelmente a partir do Mioceno Superior, em período de quiescência tectônica (Saadi, 1991).

Diferenças mineralógicas, químicas, de cor e granulométricas entre estes solos (notadamente no horizonte $\mathrm{Bw}$ ), validam a hipótese de gênese a partir de materiais de origem diferentes (Apêndices 1, 2, 3 e 4).

Os contrastes verificados entre a estrutura descrita no campo (horizontes transicionais e $\mathrm{Bw}$ ) e confirmados pela análise tridimensional de amostras indeformadas com a lupa, pela descrição micromorfológica de lâminas delgadas e pelos valores de densidade do solo, bem como pela posição destes solos nos dois sistemas (topo em SMII e meia encosta e sopé em SMI), validam a hipótese de que estes solos foram diferencialmente afetados pelos fenômenos de esculpimento do relevo.

Os Latossolos Húmicos de SMII foram pouco afetados pelos processos que esculpiram a paisagem após o Mioceno Superior, permanecendo com uma cobertura pedológica espessa e de elevada porosidade e permeabilidade, ocupando posições agora de topo (Figura 26).

Os latossolos Húmicos de SMI foram transportados a curta distância por movimentos de massa, causado por basculamento de blocos. Este transporte provocou o adensamento dos horizontes subsuperficiais, qualificado e quantificado pela descrição da estrutura do solo no campo, pelos valores bem mais elevados de densidade do solo e pelo adensamento da trama observado em lâminas delgadas, assim como pela presença de poros fissurais na matriz-S, orientados preferencialmente na direção SE-NW. As falhas 
geológicas encontradas no saprolito e no solum de um latossolo deste sistema também são orientadas na mesma direção.

No front das encostas de SMI, a reexposição do material de origem deu início a nova pedogênese. A argiluviação provavelmente ocorreu mais intensamente em uma época em que a estação seca era mais bem definida, mas ainda é verificada nos dias de hoje. As as condições mais úmidas atuais favorecem a latolização de baixo para cima deste material, evidenciada em P6 e P7.

\subsection{Gênese do horizonte A húmico}

Neste estudo foram encontrados muitos biopedotúbulos e cavidades no horizonte $\mathrm{CR}$ de um latossolo em um barranco de estrada, a $20 \mathrm{~m}$ de profundidade, em área adjacente a um cupinzeiro. Estes biopedotúbulos e cavidades normalmente estavam preenchidos com microagregados de origem biológica.

A influência da atividade da fauna na transformação de saprolito em solum é muito elevada, mas outros processos de pedogênese também atuam nesta transformação. A existência de solos em diferentes estágios de desenvolvimento, com marcas de pedogeneização diferenciadas, ocorrendo lado a lado, atesta a multiplicidade de processos pedogenéticos que atuam conjuntamente na formação dos solos, com predomínio de alguns deles variando em função de mudanças ambientais que ocorrem ao longo do tempo.

Neste sentido, estudos sobre a gênese do horizonte A húmico poderiam contribuir para ampliar a discussão sobre a idade de coberturas latossólicas, já que poucos são os latossolos que apresentam este horizonte espesso e escuro. A presença de Latossolos Húmicos gradando paulatinamente para latossolos com horizonte superficial menos espesso, dentro e entre diferentes segmentos de encosta, parece ser um indício da preservação de um material antigo e constantemente remontado, que foi pouco afetado pela remoção de materiais de sua superficie, por mecanismos fisicos, já que os demais solos da área do estudo foram depreciados pela erosão hídrica ou estão localizados nas partes rejuvenescidas da paisagem. $\mathrm{O}$ perfil de distribuição da matéria orgânica com a 
profundidade destes solos em relação aos não húmicos (Figuras 54 e 55), mostra comportamento semelhante deste parâmetro em a relação a espessura do horizonte $\mathrm{A}$. Neste sentido, os Latossolos Húmicos seriam os paleossolos expostos que menos sofreram modificações carreadas pela dinâmica do relevo, podendo ser considerados uma das chaves para o entendimento dos processos responsáveis pelo esculpimento da paisagem, que ocorreram após a formação dos mesmos.

A gênese do horizonte $\mathrm{A}$ húmico pode ser considerada como a ação conjunta diferentes fatores, culminando no processo de melanização.

A ação integrada vegetação-fauna do solo é decisiva para o espessamento do horizonte húmico. A cobertura vegetal produz a matéria orgânica e fauna produz, transforma e transporta o material orgânico, misturando-o ao material mineral.

A vegetação natural atual dos dois sistemas morfopedológicos, formada por floresta estacional semidecidual, aporta para os horizontes superficiais do solo grande quantidade de biomassa anualmente, que é revolvida, decomposta e reciclada pelos organismos do solo. Os componentes da matéria orgânica humificada (ác. húmicos, ác. fúlvicos, ác.hematomelânicos e principalmente a humina, de acordo com Stevenson, 1982) se interligam a placas de argila (Santos et al., 1989) formando complexos organominerais muito estáveis( Dabin, 1976; Stevenson, 1982; Miyasaka et al., 1983; Lepsch \& Buol, 1986; Melo, 1994). A presença de carvão é prova de que a cobertura vegetal do passado recente por vezes foi lenhosa (últimos 5.500 anos), também fornecendo matéria orgânica lignificada ao horizonte superficial. Para Schaefer (1996), a vegetação dominantes de áreas cratônicas era composta de coníferas até o Terciário Médio. Como o surgimento das gramíneas (no Eoceno), que aportam maior quantidade de matéria orgânica ao solo, coincidiu com o aumento da população e expansão areal dos térmitas, pode-se inferir que, ao longo de tempo, o suprimento de matéria orgânica foi muitas vezes suficiente para alimentar os organismos do solo e promover a melanização da superficie. A hipótese aventada por Modenesi (1996), sobre a ocorrência de temperaturas médias mais baixas durante o Quaternário na Serra da Mantiqueira, área limitrofe com região deste estudos, pode ter contribuído para a preservação da matéria orgânica nas coberturas pedológicas mais antigas. 

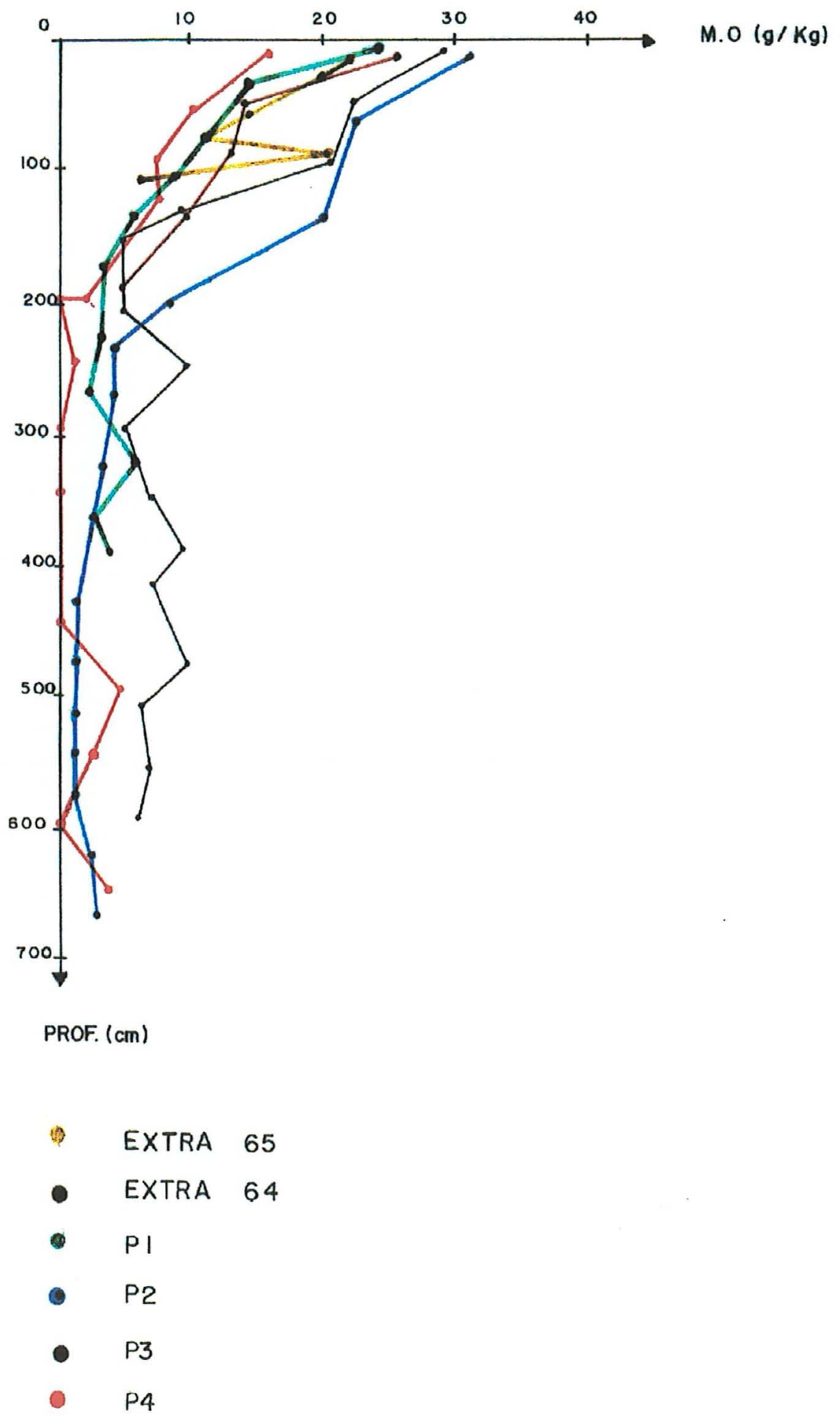

Figura 54. Distribuição da matéria orgânica com a profundidade dos perfis da encosta SW de SMII. 


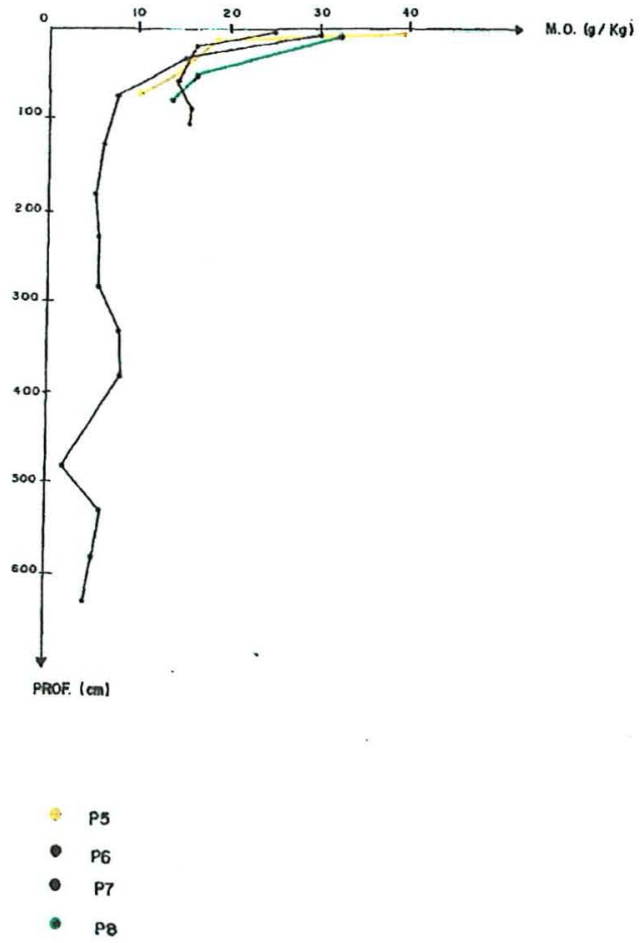

A)

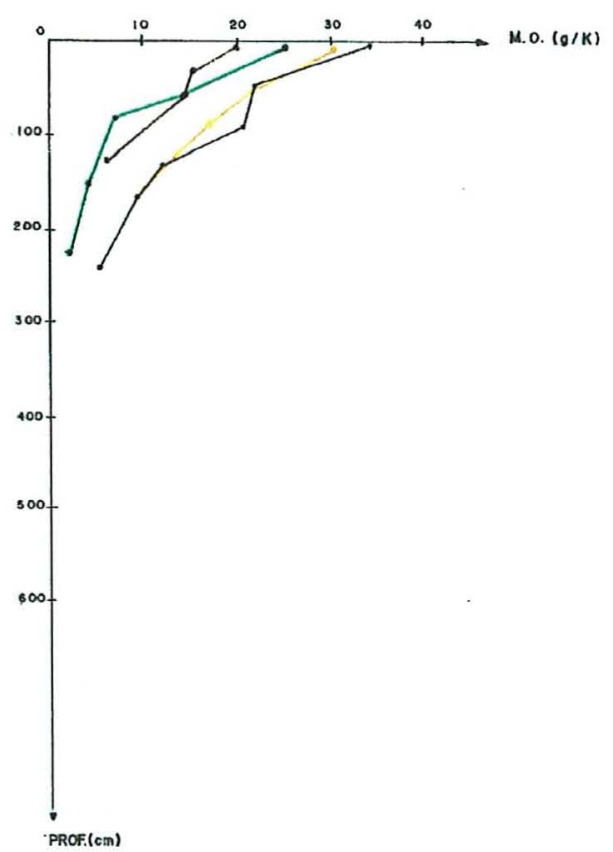

- P9
- PIO
- PII
- P12

B)

Figura 55. Distribuição da matéria orgânica em profundidade dos perfis: a) da encosta NE de SMI; B) de SMII 
O carvão presente em quantidades significativas nos horizontes húmicos, foi encontrado em todas as frações areia e na fração silte analisadas com lupa, bem como nas lâminas delgadas investigadas. O perfil de distribuição do carvão em P3 e P10 é mostrado nas Figura 56. Este material orgânico ocorre até 5,5 $\mathrm{m}$ de profundidade e chega a representar $5 \%$ da área do horizonte, se concentrando na camada de 30 a $70 \mathrm{~cm}$. Sua origem é atribuida a grandes incêndios florestais ocorridos no Quaternário, entre 3000 e 6000 anos atrás (Sanford et al.,1985; Lucas et al., 1993; Boulet et al.,1995). Restos da parte aérea de vegetação queimados e raízes carbonizadas em profundidade foram constantemente revolvidos no solo pela ação da fauna do solo. Este remonte de material pela fauna do solo pode ser comprovado pela presença de horizontes sômbricos (Perfil Extra 65, Apêndices 1, 2 e 3) em SMI e de um rede intrincada biopedotúbulos no horizonte A de todos os perfis de LH. A presença de carvões em profundidade foi considerada por Soubiés (1980) e Absy et al. (1993) como indícios de alternâncias climáticas na Amazônia, ocupada por vegetação de cerrado na época destes incêndios. Porém, Sanford et al. (1985) argumenta que áreas florestais de clima úmido também podem queimar.

Os resultados obtidos pela datação do carvão (Tabela 3) mostram um aumento da idade com a profundidade nos dois perfis de Latossolo Húmico amostrados (P3 e P10). Este aumento também foi constatado por Soubiés (1980), Sanford et al. (1985) e Lucas et al. (1993) em solos da Amazônia e por Boulet et al. (1995) em solos do Triângulo Mineiro, situados a $250 \mathrm{~km}$ da área deste estudo. As idades encontradas por este pesquisador também se assemelham àquelas obtidas neste trabalho.

O carvão coletado em P10 (localizado no topo do SMII) apresenta idades bem recentes na superficie (300 anos), que se elevam, até alcançar 4150 anos a cerca de 135 $\mathrm{cm}$ da superfície. Tal fato sugere que os últimos incêndios ocorreram on período colonial (época da ocupação da área) e que os incêndios mais antigos se deram praticamente nas mesmas épocas dos incêndios encontradas por Soubiés (1980), Sanford et al. (1985) e Lucas et al. (1993) e por Boulet et al. (1995). 


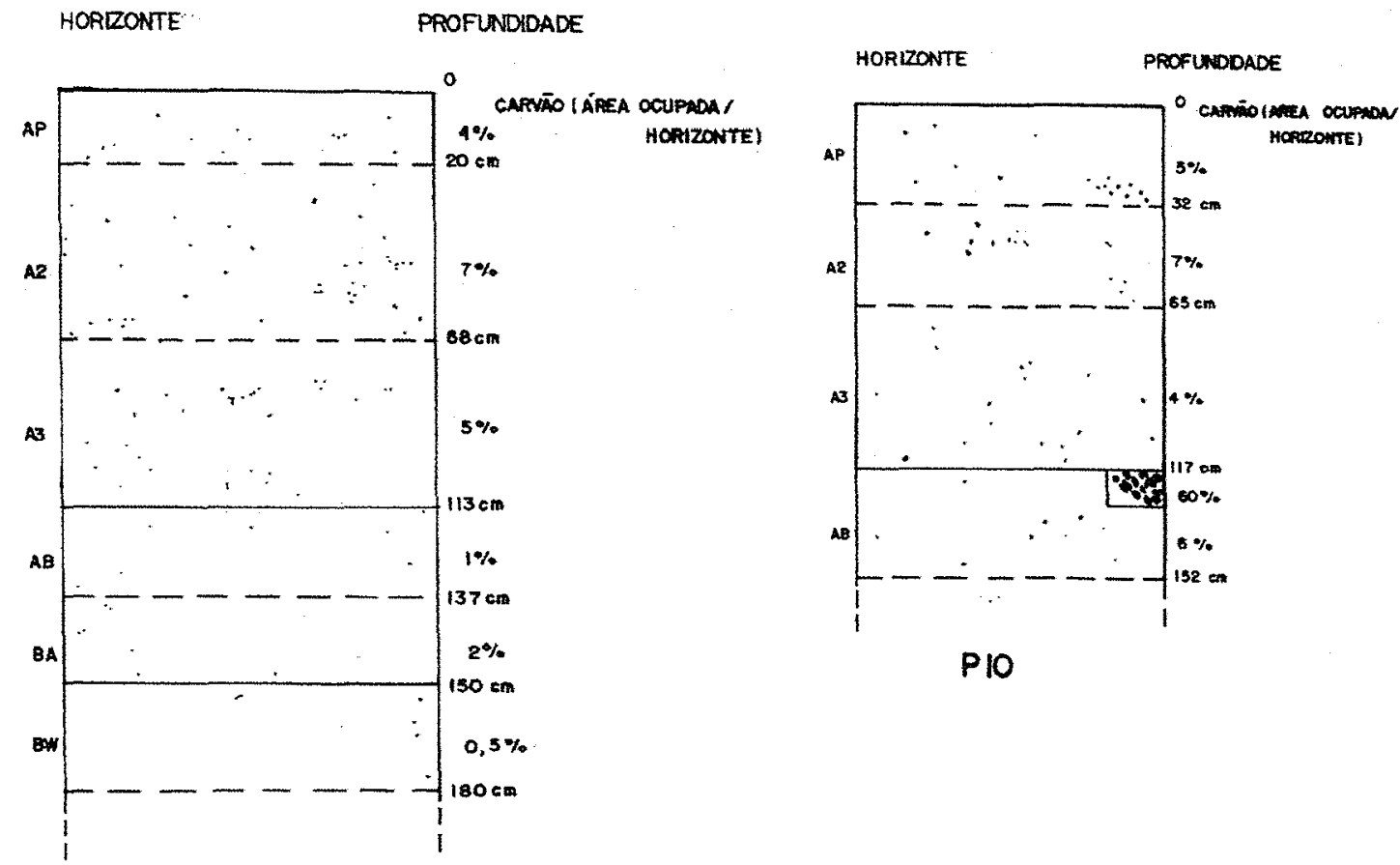

P3

ESCALA I:20

Figura 56. Perfil de distribuição do carvão com a profundidade em P3 (SMI) e P10 (SMII). 
Tabela 3- Datação do carvão do solo, coletado a diferentes profundidades em dois perfis de Latossolo Húmico, pelo método do $\mathrm{C}^{14}$

\begin{tabular}{cccc}
\hline Perfil & $\begin{array}{c}\text { Profundidade } \\
\text { (cm) }\end{array}$ & $\begin{array}{c}\text { Idade } \\
\text { (anos) }\end{array}$ & $\begin{array}{c}\text { Desvio padrão } \\
\text { (anos) }\end{array}$ \\
\hline \multirow{2}{*}{ P3 } & $0-20$ & 2260 & \pm 90 \\
& $20-68$ & 3600 & \pm 40 \\
& $68-113$ & 5330 & \pm 50 \\
& & & \pm 70 \\
& $0-32$ & 280 & \pm 80 \\
& $32-65$ & 2100 & \pm 30 \\
\hline
\end{tabular}

Como P10 se situa no topo de uma encosta e não recebeu colúvios, a hipótese mais provável de seu enterramento é a atividade da fauna do solo, como proposto por Boulet et al. (1995) para solos do Triângulo Mineiro.

As idades dos fragmentos de carvão coletados em P3 (localizado em um sopé do SMI) vairam de 2260 anos na superficie a 5330 anos no horizonte localizado entre 68 e $113 \mathrm{~cm}$ de profundidade. Ausência de fragmentos de carvão de idade do período colonial brasileiro na superfície dá margens a elaboração de duas hipóteses: a) não houveram grandes incendios nesta área durante o período colonial; b) Uma camada superficial do solo, de aproximadamente $35 \mathrm{~cm}$ de espessura, foi retirada deste local. Os movimentos de massa, evidenciados e discutidos nos capitulos anteriores, poderiam ser os responsáveis pela retirada deste material. Neste caso, eles também ocorreram durante o Quaternário. Está constatação pode ser mais uma evidência da ação da tectônica ressurgente (neste caso, holocênica) neste sistema morfopedológico. A combinação destas hipóteses parece ser a explicação mais plausível.

O carvão e os hábitos construtor e alimentar da fauna do solo têm fundamental importância na melanização do horizonte superficial em profundidade, originando o A 
húmico. Como descrito no capítulo anterior, este horizonte pode ser considerado um emaranhado de biopedotúbulos preenchidos por microagregados arredondados $\mathrm{e}$ brunados, a maioria de origem biológica. A Figura 35 mostra a diminuição da densidade de biopedotúbulos preenchidos/área, com a profundidade. $\mathrm{O}$ horizonte $\mathrm{A}$ húmico é totalmente ocupado por estes biopedotúbulos, enquanto que no horizonte $A B$ eles representam $40 \%$ da área exposta, contra $25 \%$ em BA e apenas $10 \%$ em Bw.

As análises morfológicas e micromorfológicas corroboram as observações desta Figura. Esta constatação sugere um espessamento atual do horizonte húmico pela ação da fauna do solo, que constrói canais e cavidades, leva o material retirado para as camadas superiores e depois preenche os mesmos com agregados de origem biológica fabricados nas proximidades da superficie. O material remontado para a superfície é avermelhado ou amarelado, de acordo com observações tomadas no campo e confirmadas nas lâminas delgadas, onde ocorrem como microagregados de origem biológica, de croma e valor altos (Figura 57), assim como são brunados muitos daqueles que preenchem os biopedotúbulos a grandes profundidades (Figura 58). A análise da fração areia em microscópio petrográfico, confirmada posteriormente pela observação de amostras indeformadas com a lupa (descrita no capítulo anterior) mostra que, notadamente no horizonte $\mathrm{A}$, cerca de $20 \%$ em média dos fragmentos de areia na verdade são microagregados de origem biológica que não foram destruídos pela dispersão das amostras. Esta observação ajuda a explicar o menor teor de argila verificado no horizonte Ap dos latossolos húmicos.

Os agregados de origem biológica maiores que $1 \mathrm{~mm}$ estão se partindo em outros (Figura 59), se dispersando na matriz do solo, aumentando o efeito de melanização da mesma. Estes agregados são formados pela cimentação e escurecimento de plasma e esqueleto por substâncias orgânicas produzidas pela fauna do solo. As substâncias orgânicas, principalmente a humina, se ligam as argilas, formando complexos muito estáveis ( Dabin, 1976; Stevenson et al., 1982; Miyasaka et al., 1983; Lepsch \& Buol, 1986; Melo, 1994). Esta estabilidade pode provocar a concentração residual de agregados, inteiros ou fragmentados, de origem biológica. Como eles são mais escuros, a 


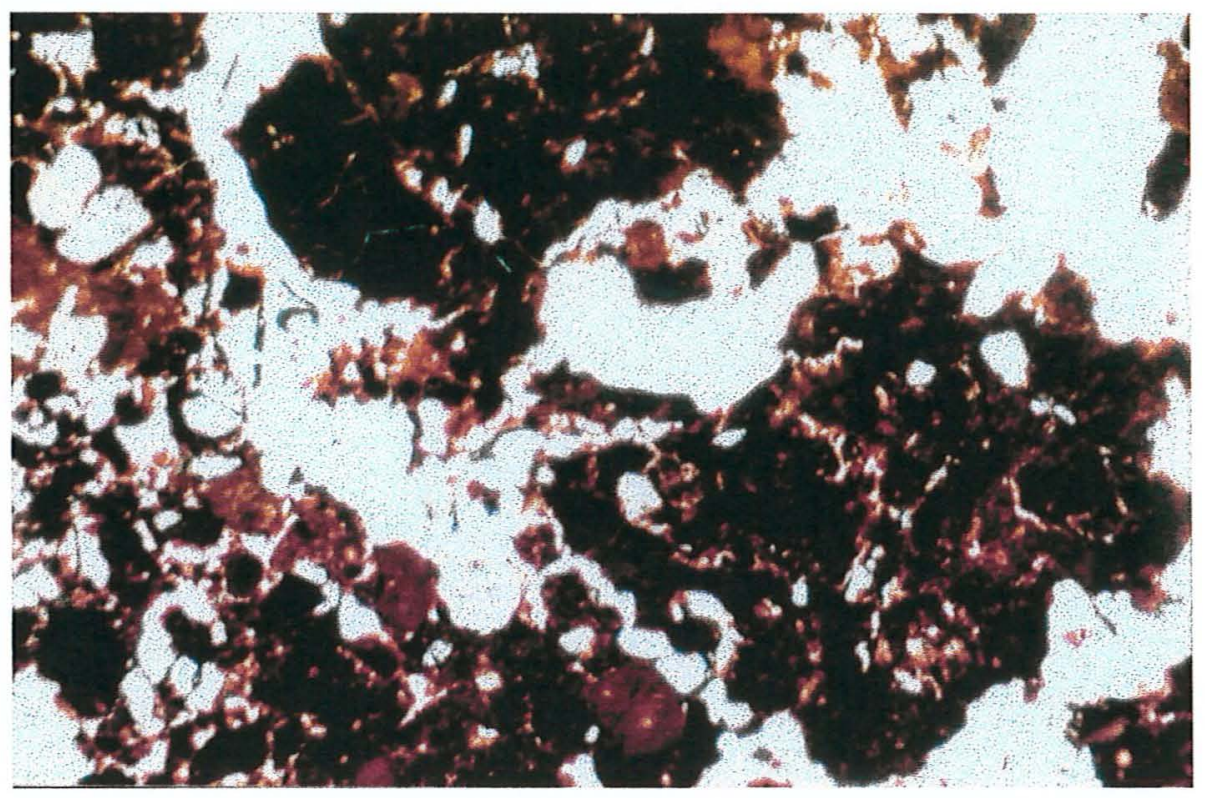

Figura 57. Fotomicrografia do horizonte Ap de P10. Detalhe: Agregados vermelhos arredondados.

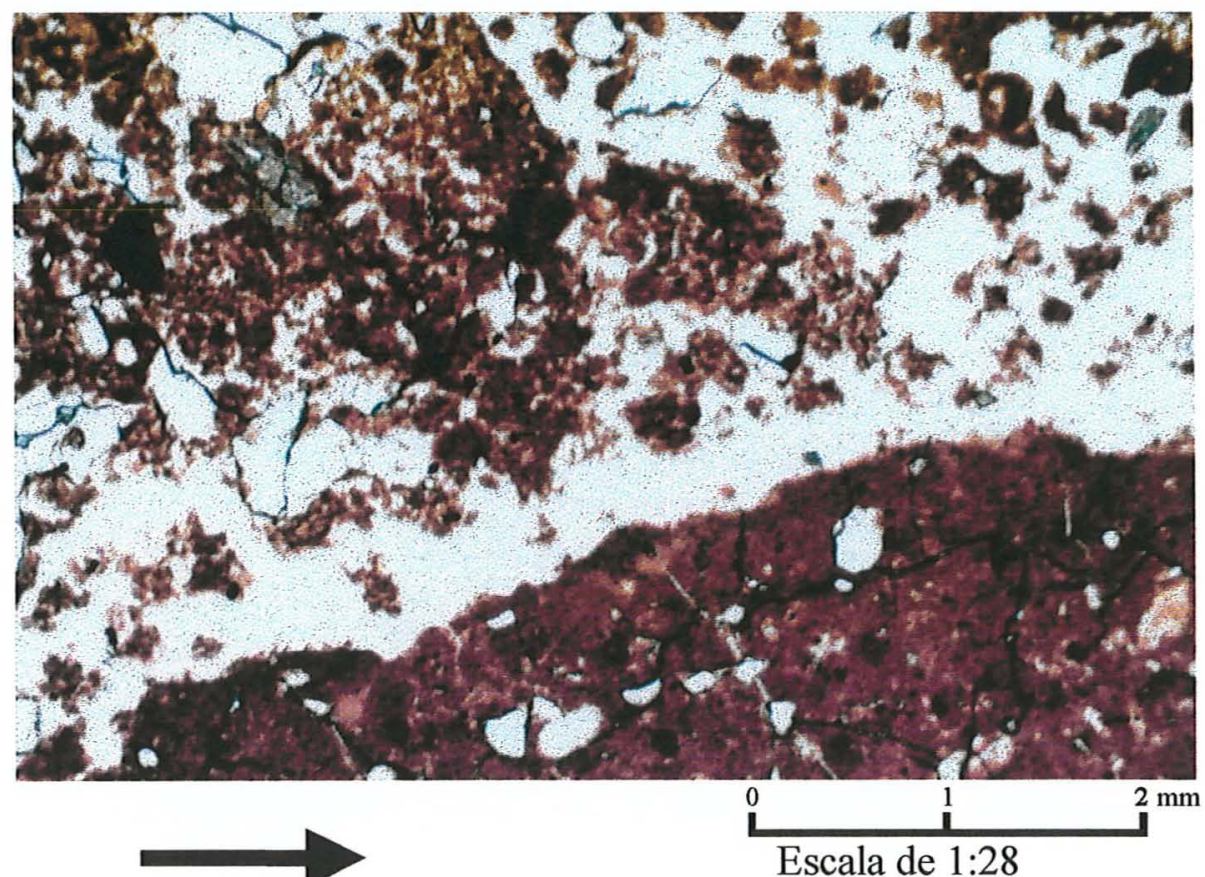

Figura 58. Fotomicrografia do horizonte Bw de Extra 64. Detalhe: cor brunada dos agregados que estão preenchendo os biopedotúbulos. 


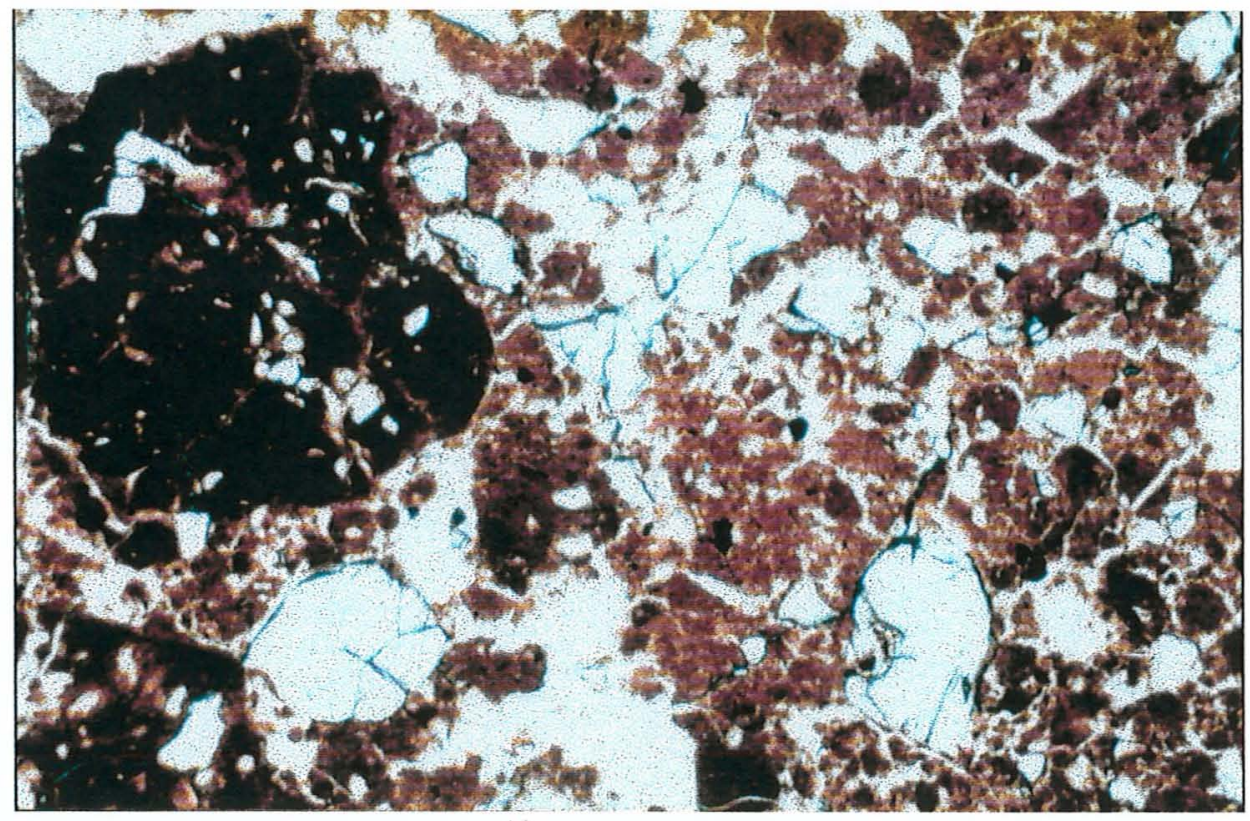

A)

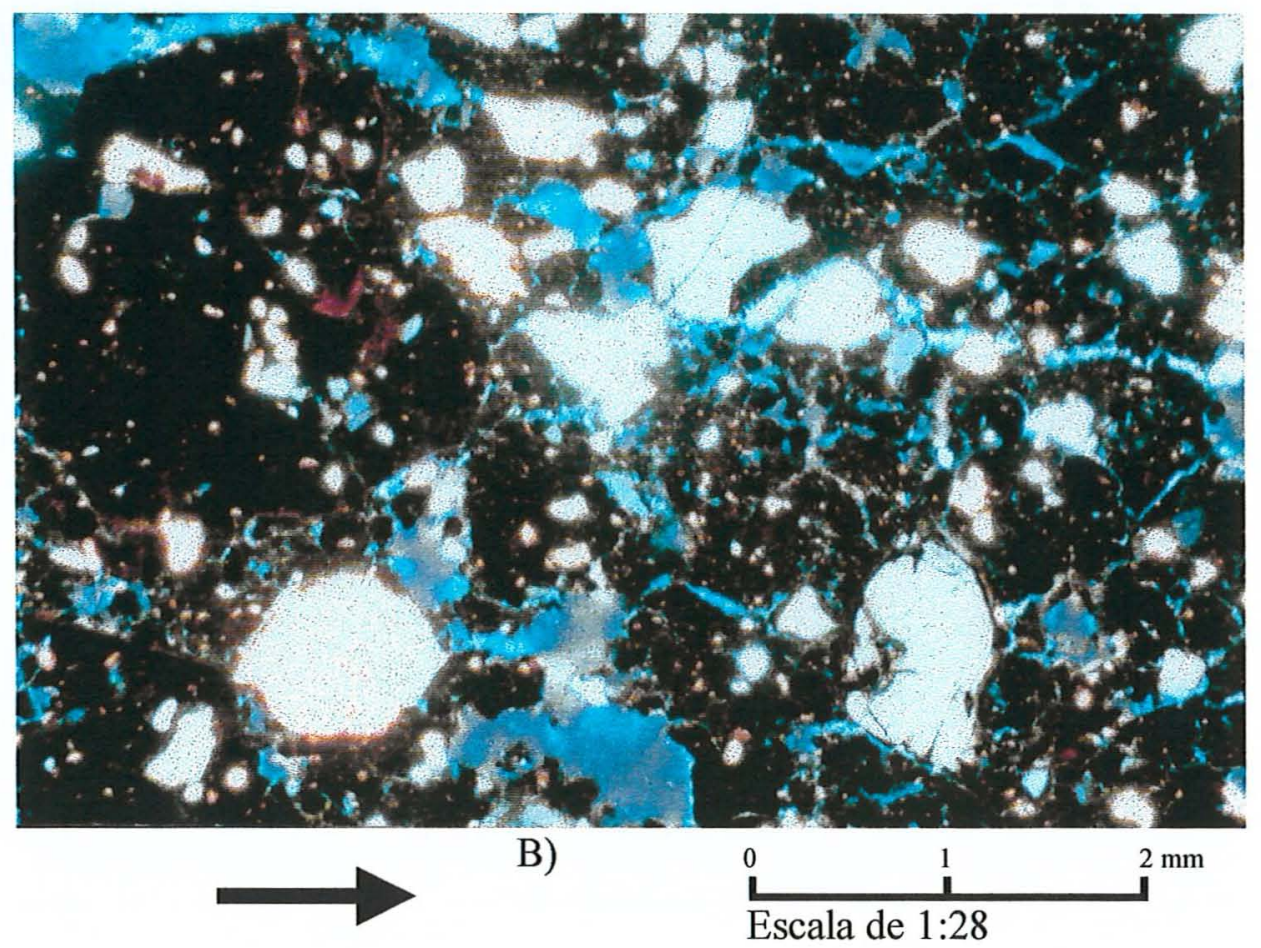

Figura 59. Fotomicrografia do horizonte $\mathrm{A} 2$ de $\mathrm{P} 2$, sob luz incidente (A) e sob luz polarizada (B). Detalhes: A) microagregado de $2 \mathrm{~mm}$ se partindo; B) avermelhamento do carvão 
melanização do horizonte A progride com o tempo e em profundidade, pelo remonte vertical.

O carvão é outro componente do pedossistema que influencia decisivamente a melanização do horizonte A. Presente em quantidades que variam de 3 a $8 \%$ em todas as lâminas delgadas de horizonte e subhorizontes húmicos analisados, podem ocorrer isoladamente (fragmentos maiores), ou constituíndo o esqueleto triado de microagregados de origem biológica.

Os fragmentos de carvão do esqueleto das microunidades estruturais zoogenéticas normalmente são arredondados (Figura 31) e, como são manipulados, transportados e depositados, por regurgitação ou excreção pela fauna do solo (Echenbrenner, 1996), se decompõe com maior facilidade, pois cupins e outros insetos também são capazes de degradar a lignina pela presença de um microorganismo em sua flora intestinal (Melo, 1994). Esta decomposição é predominantemente perimetral, e resulta em material plásmico bruno-avermelhado a bruno médio que se espalha pela matriz do solo e contribui para a melanização deste horizonte. As Figuras 50 e 60 demonstram este processo. O plasma escurecido originado da decomposição do carvão pode ser diferenciado do plasma escurecido originado de atividade biológica através de fotografias polarizadas ( Figuras 59; 60 e 61). Elas mostram que o primeiro tem sua tonalidade bruno avermelhada intensificada enquanto o segundo apenas escurece. As Figura 53 e 63 mostram uma raiz em decomposição e evidenciam as cores avermelhadas advindas da matéria orgânica. As formas arredondadas observadas na Figura 63 têm sua origem atribuída a colonização de fragmentos de raíz em decomposição por fungos.

A migração de substâncias pré-húmicas através do perfil do solo, dando origem aos ácidos húmicos, fúlvicos e a humina em profundidade (Volkoff et al., 1978) também pode contribuir para o espessamento do horizonte A.

Em síntese, a gênese do horizonte $\mathrm{A}$ húmico pode ser atribuída a estabilidade da ligação humus-argila, que provoca melanização por concentração residual. Seu escurecimento está relacionado a produção de microagregados pela fauna do solo e a decomposição do carvão, enquanto seu espessamento está intimamente ligado a 


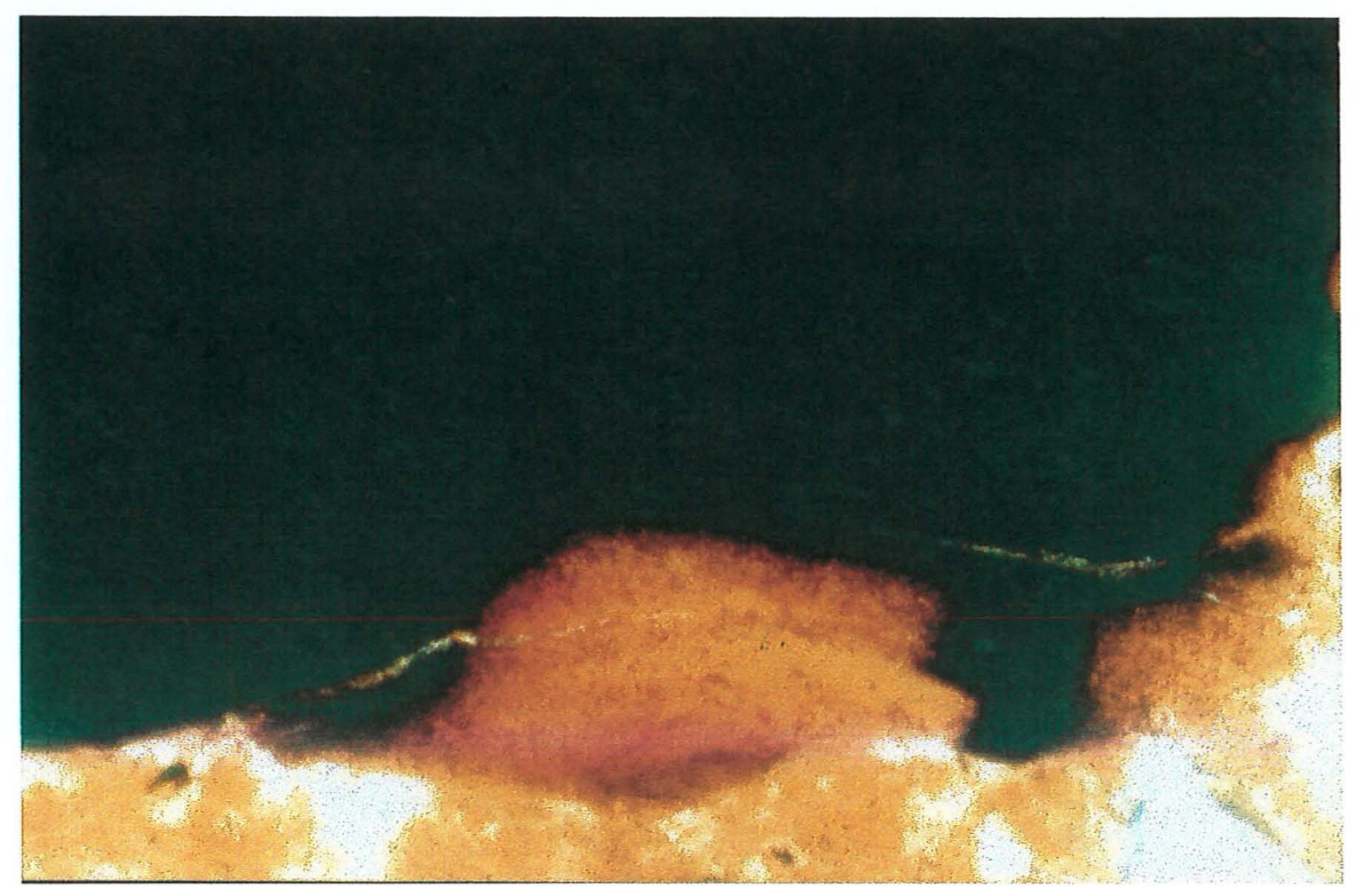

Figura 60. Detalhe do carvão se decompondo no horizonte $\mathrm{AB}$ de $\mathrm{P} 2$, resultando em material plásmico bruno avermelhado e brunado.

construção de canais e cavidades em profundidades superiores a $1 \mathrm{~m}$ pela fauna do solo, causando o revolvimento do solo e, secundariamente, a migração de substâncias pré-húmicas e a sua modificação a humus em profundidade.

Como poucos são os latossolos atuais que apresentam este horizonte espesso e escuro, pode-se deduzir que os mesmos são pedorrelíquias, ou seja, o início de sua pedogênese remonta ao Terciário. Provavelmente desde esta época a fauna do solo transloca material através do perfil deste solo. Sua presença está relacionada a áreas estáveis da paisagem, pouco afetadas pela degradação de materiais da superfície da cobertura pedológica. Sua gênese se constitui em um elo fundamental de ligação entre os solos e os fenômenos que esculpiram a paisagem atual. 

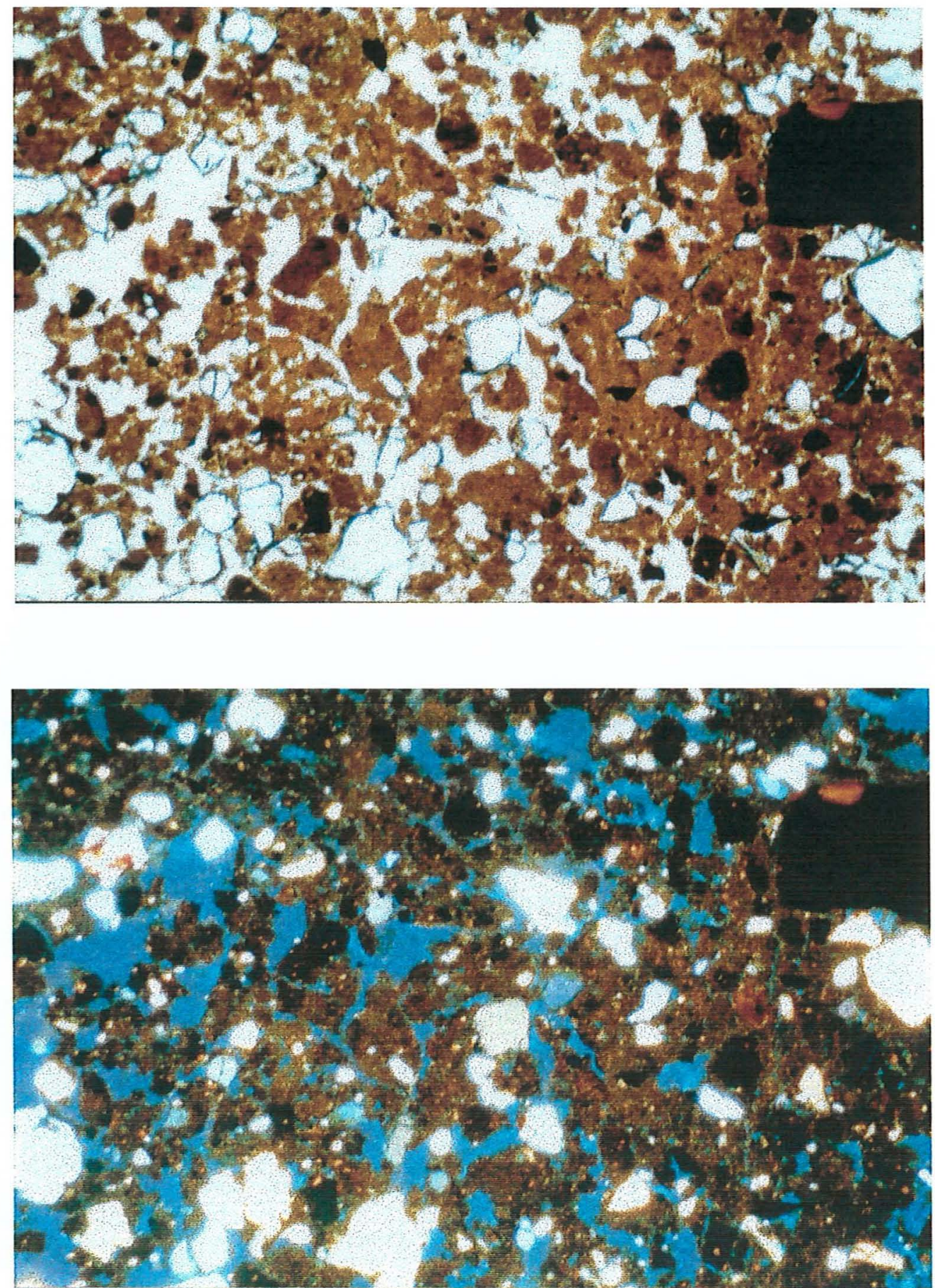

B)

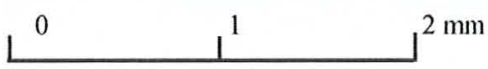

Escala de 1:28

Figura 61. Fotomicrografia do horizonte $\mathrm{AB}$ de $\mathrm{P} 2$, mostrando que as cores avermelhadas que aparecem na periferia dos fragmentos de carvão sob luz incidente (A), se intensificam com nicóis cruzados(B). 

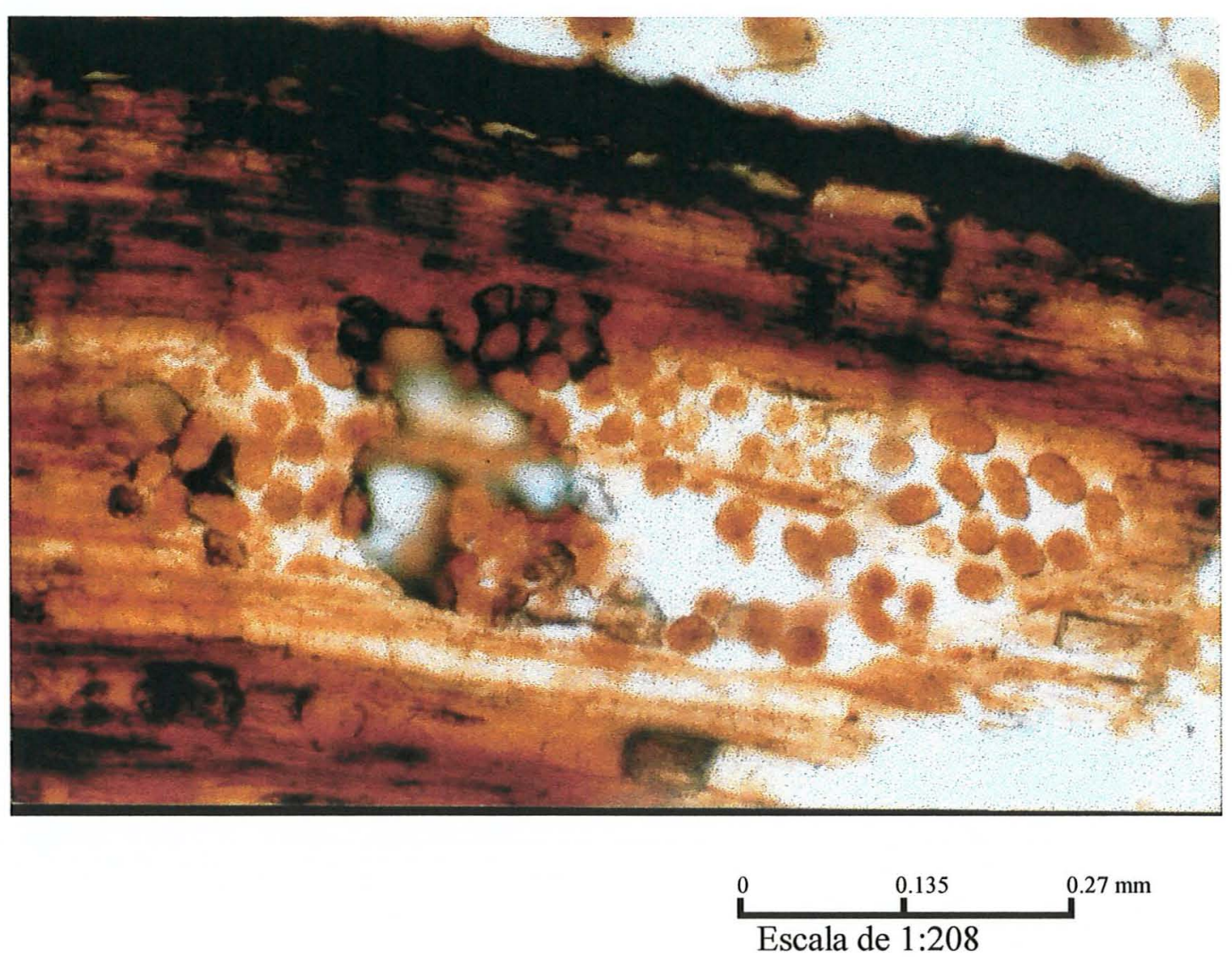

Figura 62. Fotomicrografia do horizonte Bw de P12. Raiz em decomposição.

Detalhe: cores avermelhadas.

\subsection{Evolução cronológica da paisagem e dos solos}

A sucessão de eventos que culminaram na conformação atual da paisagem desta área cratônica do centro-sul de Minas Gerais, remonta a um período de quiescência tectônica da Era Mesozóica (Cretáceo Superior), com a instalação da Superfície Gondwana (King,1956) em duas litologias metamorfizadas do Pré-Cambiano: o Complexo Amparo e o Complexo Guaxupé, (Fiori,1979, Radambrasil, 1983, Minas Gerais, 1983; Schobbenhaus et al. 1984, Artur,1988). Estes Complexos de rocha, que seriam antigos continentes que colidiram, embasam a região denominada por Hasui et al. (1990a) como "Cunha de Guaxupé". Esta região, palco deste estudo pedológico e 
morfológico em escala local, é bordejada pelos cinturões transcorrentes Cássia-Barbacena (E-NW) e Carandai-Ouro Fino (NE-SW), (Almeida, 1980; Wernick et al. 1981; Hasui et al., 1990a; Saadi, 1990 e 1991), zonas preferenciais para os movimentos tectônicos (Figura 63 -To).

A partir do Cretáceo Inferior até o início do Paleoceno, o vulcanismo alcalino ocorrido na região de Poços de Caldas (a $50 \mathrm{Km}$ em linha reta da área deste trabalho) formou uma imensa caldeira (Leinz \& Amaral, 1985) que causou perda de massa magmática abaixo da litosfera, arqueamentos e fraturamentos regionais.

Os movimentos tectônicos das bordas da "Cunha de Guaxupé", juntamente com o vulcanismo de Poços de Caldas, fragilizaram as áreas de junção entre estruturas geológicas pré-cambrianas (os complexos Amparo e Guaxupé), provocando o basculamento de grandes blocos litológicos, movimentando o relevo (Figura 63 - T1).

No Eoceno-Mioceno, em períodos de quiescência tectônica (Schaefer,1996), o relevo regional foi reafeiçoado. Durante estes períodos, eventos morfoclimáticos predominavam na dinâmica das paisagens. Em uma época seca muito prolongada, de 250.000 anos, (Penteado,1968; Melo,1995) teria-se originado a Superficie de Aplainamento Sul Americana (King, 1956), também proposta por vários outros autores (De Martonne, 1953, Almeida, 1959; Radambrasil, 1983; Minas Gerais,1983), mas com denominações próprias. Todo material pedológico formado até então teria sido removido (Figura 63 - T2).

A reinstalação das condições umidas a partir do Mioceno superior proporcionou um intenso intemperismo das rochas, formando um espesso regolito. A latolização deste material se intensificaria pela explosão populacional e areal dos térmitas, ocorrida, de acordo com Schaefer (1996), no Terciário Médio. A melanização do horizonte superficial da cobertura pedológica possivelmente também se iniciou nesta época, em virtude da incorporação no solo da matéria orgânica produzida pela vegetação. A humina, produzida pela decomposição da matéria orgânica, se ligaria as argilas do solo, formando complexos altamente estáveis (Stevenson, 1982; Lepsch \& Buol, 1986; Siqueira \& Franco, 1988; Melo, 1994). O avanço do escurecimento em profundidade se daria pelo 
To

CRETÁCEO

SUPERIOR

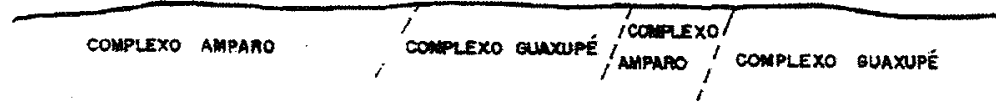

TI

CRETÁCEO INFERIOR/

PALEOCENO SUPERIDR

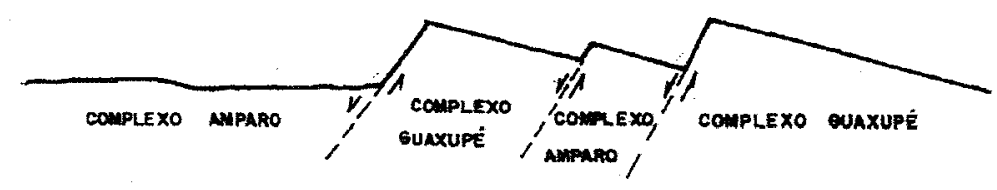

T2

EOCENO/

MIOCENO

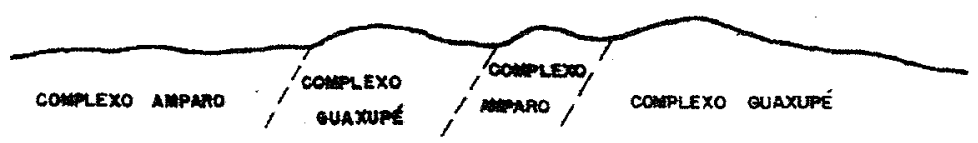

T3

MIOCENO

SUPERIOR
T4

MIOCENO

MÉDIO E

NFERIOR
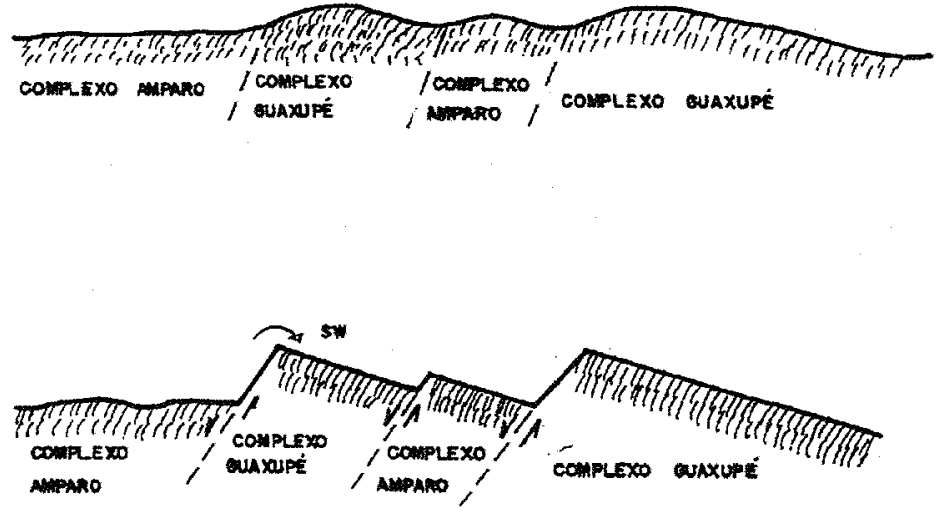

Ts

PLIOCENLQ!

PLEISTOCENO/

HOLOCENO

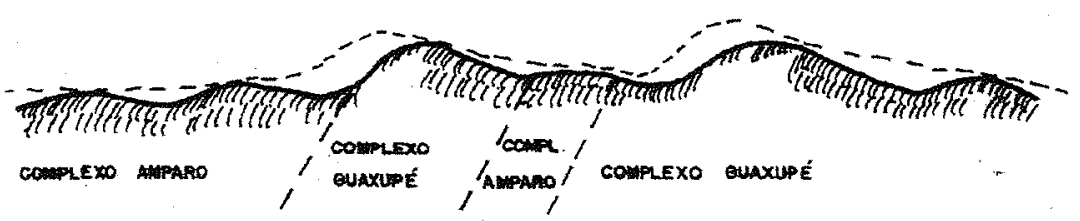

Figura 63. Sequência de evolução do relevo ao longo do tempo geológico 
revolvimento do solo pela fauna, devido aos seus hábitos alimentar e construtor (Eschenbrenner, 1986; Miklós, 1992, 1996) (Figura 35), levando agregados mais escuros e particulas de carvão para camadas mais profundas e trazendo material do horizonte $B$ para ser melanizado na superfície. A decomposição do carvão e a migração de substâncias pré-húmicas, ao longo do tempo, também contribuem efetivamente para o escurecimento do horizonte A (Figura 63-T3).

A aceleração do soerguimento das Serras do Mar e da Mantiqueira no Mioceno Médio, proporciona uma reativação tectônica (Saadi, 1991), ocasionado uma removimentação gradual, mas com intensidade diferenciada, dos blocos estruturais no sentido SW.

A cobertura latossólica do reverso destes blocos basculados teria sido transportada a curta distância, sendo deslocada por movimentos de massa das posições de topo, onde rochas passaram a aflorar. Nestes reversos, os processos de pedogeneização permaneceriam atuando ao longo do tempo, variando apenas em intensidade. No front, solum e saprolito (todo ou em parte) foram removidos, formando escarpas e causando a retomada dos processos geomorfogênese e pedogênese (Figura 63-T4).

A paisagem atual teria sua conformação iniciada no Plioceno, com o recuo das encostas e reinstalação da rede de drenagem. Os mecanismos que ativaram o intemperismo e a erosão/dissecação teriam sido as alternâncias entre climas úmidos e semi-áridos (Bigarella et al., 1965a e 1965b), notadamente nas áreas mais estáveis, embasadas por apenas uma litologia (SMII). Nos locais onde os blocos foram basculados (SMI), os movimentos tectônicos residuais, persistentes até os dias atuais (Mioto, 1984 e 1990; Saadi 1991), e comprovados pela presença de espelhos de falha no saprolito e no solum da cobertura pedológica, influenciaram e influenciam o afeiçoamento do relevo.

$\mathrm{Na}$ áreas representadas por SMII, o horizonte A húmico foi removido predominantemente por erosão hídrica, permanecendo apenas em alguns topos das colinas suavizadas. Nas áreas mais movimentadas (SMI), o Latossolo Húmico permaneceu nos interflúvios do reverso dos blocos basculados, sendo apenas remanejado a curta distância. A ação da fauna do solo continuou a ser efetiva e os processos que 
levam a melanização do horizonte A e a latolização do saprolito avançam em profundidade. No front destes blocos de rocha, ciclos de pedogênese e erosão levaram a formação de uma sequência de solos pouco desenvolvidos associados a afloramentos de rocha ( nos segmentos de topo e meia encosta) e solos podzólicos ( nos segmentos de ombro e sopé) (Figura 63- T5). 


\section{CONCLUSÕES}

1) A tectônica ressurgente é um dos fatores responsáveis pela adição de energia requerida pelos processos de formação da paisagem da área estudada. A reativação de falhas geológicas durante o Terciário e o Quaternário provoca o basculamento de blocos litológicos, induzindo os movimentos de massa e o reafeiçoando o relevo. As evidências desta ação são a ocorrência de sismos nos dias atuais; os falhamentos e fraturamentos observados a partir de fotos aéreas; feições geomorfológicas como topo escarpado com solos rasos e pedregosos associados a formas trapezoidais pontuadas por matacões no sopé; sequência de falhas orientadas no sentido SE-NW no saprolito e no solo em corte de estrada, onde foram constatadas superficies polidas com estrias (espelho de falha). A descrição de lâmina delgada confeccionada a partir de material coletado no espelho de falha revelou a presença de uma estrutura de cizalhamento.

2) A distribuição dos solos na paisagem do SMI deve ter sido muito influenciada pelos movimentos de massa, movimentando materiais a curta distância através dos interfluvios de sua encosta $\mathrm{NE}$, com retirada de materiais pédicos predominantemente da superfície. Na encosta SE (escarpa da falha), a remoção de materiais foi acentuada, expondo rochas a um novo ciclo de intemperismo. Matacões e callhaus ao longo da superfície e dos perfis dos solos das escarpas de linha de falhas; o adensamento do solo situado em um sopé deste sistema e os poros fissurais da matriz $\mathrm{S}$ orientados no sentido SE-NW são evidências destes processos. A descontinuidade litológica observada no sopé da encosta NE de SMI, assim como a ausência de carvão de idade inferior a 350 anos na superficie deste mesmo solo também evidenciam a ação destes processos geológicos e geomorfológicos.

3) O controle estrutural também influencia decisivamente as formas de relevo do SMI. Lentes de rochas félsicas, interpostas entre rochas máficas, passam a compor os 
afloramentos, pela resistência diferenciada ao ao intemperismo. Topos com afloramentos de rochas, soleiras, anfiteatros suspensos e escarpas comprovam esta influência.

4) A erosão hídrica é o principal processo de esculpimento da paisagem em SMII. O aumento da quantidade de areia encosta abaixo; a discrepante distribuição de areias entre os perfis situados no topo (P9 e P10) em relação aos situados na meia encosta e sopé (P11 e P12) e as relações entre as cores dos horizontes dos solos nas diferentes posições da encosta, mostrada pela análise estrutural, atestam o transporte via água.

5) A linha de pedras do SMI é de origem residual. Sua forma de ocorrência (acompanhando o relevo interno), a pobre seleção de seus fragmentos de gnaisse ferruginizado, sua distribuição e a elevada relação de filiação dos fragmentos pequenos em relação aos grandes comprovam esta origem.

6) Os microagregados dos latossolos da área deste estudo são originados por quatro processos: zoogênese, geoquímica relacionada ao ferro, estruturação, e complexação. Os microagregados zoogenéticos apresentam forma externa oval, esqueleto interno triado com partículas de carvão, e cores mais escuras e brilhantes. São observados em escala macro e micromorfológica. A desferrificação parcial resultante da transformação de hematita em goethita poderia promover a individualização de micronódulos, unidade fundamental para a formação geoquímica de microagregados. Os microagregados estruturais se formariam por fissuração do plasma, adensado pela ação da fauna, por ciclos de umidecimento e secagem ou por movimentos de massa. Este adensamento, por sua vez, influencia a formação de agregados complexos.

7) O horizonte húmico foi formado a partir de intensa melanização. Este processo é provocado pela entrada e permanência da matéria orgânica no sistema. A fauna do solo é responsável pela adição de matéria orgânica, translocação de materiais dentro do perfil e transformação de material orgânico em humus. Microagregados de cores brunadas produzidos pela fauna são transportados para as partes inferiores do perfil, enquanto que materiais pédicos de cores mais claras são transportados para a superfície, onde são melanizados, provocando a formação e o escurecimento dos microagregados e o espessamento do horizonte húmico, o que é comprovado pelo 
aumento da idade do carvão com a profundidade em P10, datada pelo método do $\mathrm{C}^{14}$ (variando de 280 anos na superfície e 4150 anos a $135 \mathrm{~cm}$ de profundidade). Este perfil foi descrito na posição de topo do SMII, onde a relação $\mathrm{Ti} / \mathrm{Zr}$ e a distribuição de areias permaneceram constantes em profundidade. Estas constatações evidenciam a ausência de coluvionamento neste local. A decomposição do carvão, gerando material plásmico brunado, também contribui significativamente para o escurecimento deste horizonte, que somente é encontrado no presente em alguns nos topos de SMII (onde foi preservado da erosão hídrica) e nos interflúvios da meia encosta e do sopé da vertente NE de SMI (onde foi transportado a curta distância por movimentos de massa e também preservado da erosão hídrica).

8) Os latossolos húmicos foram pouco afetados por processos que levam à retirada de seus materiais constituintes. A fauna do solo pode estar translocando os materiais destes solos desde o Terciário, enquanto que os outros latossolos perderam parte ou todo seu horizonte superficial e os podzólicos se situam nas áreas rejuvenescidas da paisagem. Eles constituíram em um elo fundamental para o entendimento da dinâmica da paisagem nas quais estão inseridos, sendo considerados paleossolos .

9) O estabelecimento do modelo de evolução da paisagem só foi possível pela integração de informações de caráter geológico, geomorfológico e pedológico. 


\section{REFERÊNCIAS BIBLIOGRÁFICAS}

Ab'SABER, A.N.; BERNARDES, N. Vale do Paraíba, Serra da Mantiqueira e arredores de São Paulo. Guia da Escursão $n^{\circ}$ 4. In: CONGRESSO INTERNACIONAL DE GEOGRAFIA, 18, Rio de Janeiro, 1958. Anais. Rio de Janeiro, Conselho Nacional de Geografia, 1958. p.7-32.

Ab'SABER, A. N. Revisão dos conhecimentos sobre o horizonte superficial de cascalhos inhumados do Brasil Oriental. Notícia Geomorfológica, v.6, n.11, p. 59 $-80,1966$.

ABSY, M. L., ClEEF, A; FOUNIER, M.; MARTIN, L. SERVANT, M.; SIFFEDINE, A.; FERREIRA DA SILVA, M.; SOBIES, F.; SUGUIO, K.; TURQ, B. ; Van DERHAMEN, T. Nise en évidence de quatre plases d'ouvertue de la forêt dense dans le sud-est de l'Amazonie ou cours des 6.000 dernieres annés. Premeire comparaison avec d'autres régions tropicales. C.R. Acad. Sci. Paris, t. 312, Série II, p. 673 - 678, 1991.

ABSY, M. L. ; SERVANT, M. ; ABSY, N.L. A história do clima e da vegetação pelo estudo do pólem. Ciência Hoje, v. 16, n.93,p.26-30,1993.

ALAILY, F. Soil formation on limestones in the arid region of Northeast- Somalia. Catena, v.20, n.3, p.227-246,1993.

ALLEN, B. L. ; FANNING, D. S. Composition and Soil Genesis. In: L. P. Wilding, N. E Smeck e G. F. Hall (eds).Pedogenesis and Soil taxonomy. I. Concepts and interactions . Amsterdan: Elsevier, 1983. P.141-192. 
ALMEIDA, F. F. M. de. Traços gerais da geomorfologia do Centro-Oeste brasileiro. In: CONGRESSO INTERNACIONAL DE GEOGRAFIA, 18, rIO DE jANEIRO, 1959. Anais. Rio de Janeiro, Conselho Nacional de Geografia, 1959. P. 7-65.

ALMEIDA, F. F. M. de. O Cráton do Paramirim e suas relações com o do São Francisco. In: SIMP. SOBRE O CRATON DO SÃO FRANCISCO E SUAS FAIXAS MARGINAIS, Salvador, 1979. Anais... Salvador: SME-BA / SBGBA,1981. p. 1-10.

ALMEIDA, A. F. M.; HASUI, Y.; DAVINO, A.; HARALY, N. L. E. Informações geofísicas sobre o oeste mineiro e seu significado geotectônico. An. Acad. Bras. Ciências, Rio de Janeiro, v. 52, n. 1, p. 49-60, 1980.

AMAL-KAR et al.. Morphological processes responsible of land degradation due to water and win erosion in the Indian desert. Rehabilitation of degraded nad ecossystem, v.2, p.85-95,1992. / Resumo em CAB Abstracts CD-ROM ,1992/

AMARAL, G. Potassium-argon dates of basaltic rochs from Southern Brasil. Geochimica et Cosmo Chimica Acta, v. 30, n. 2, p. $188-189$, jan-jun. 1966.

ANDRADE, H. Caracterização genética, morfológica e classificação de dois solos do município de Lavras (MG) em correlação com a geomorfologia da área. Lavras, 1979. 98p. Dissertação ( M.S.) Escola Superior de Agricultura de Lavras.

ARTUR, A.C. Evolução policíclica da infra estrutura da porção sul do Estado de Minas Gerais e regiões adjacentes do Estado de São Paulo. São Paulo, 1988. 232p. Tese (Dr.) Instituto de Geociências-USP.

BACHELER, G. La faune des sols. Son écologue et son action. ORSTOM. Int. Doc. teach. n. 38, 391p. 1978.

BEADOU, A. G.; CHATEZIN, Y.; COLLINET, J.; SALA, G. H. Notes sur la micromorphologie de certains ferralitiques jaunes de regions équatoriels d'Afrique. Cah ORSTORM, Ser. Ped. v. 4, p. 357 - 370, 1972. 
BEADOU, A. G.; FROMAGET, M. ; GUICHARD, E. Análysis of the macro and microotruturales de sols ferralitigues centrafricains issus de roches basiques. Réunion INTERnationale de Micromorphologie des sols, 7 , Paris,1987. Anais .Paris: Edite par.N.Fedoroff et L.M. Bresson, p. 119 - 124, 1987.

BECKER, A. A time-space model fot the genesis of Early Tertiary laterites from the Jos Plateau, Nigéria. Journal of African Earth Sciences, v15, n.2, p. 265-269, 1992. /Resumo em CAB Abstracts on CD-ROM, 1992/

BERG, M. van den; LEPSCH, I.F. ; SAKAI, E. Solos de planícies aluviais do Vale do Rebeira do Iguape: II Relações entre características químicas e físicas. Rev. bras. Ci. Solo, v. 11, n. 2, P. 315-321, 1987.

BICKI, T.J. ; TANDARICH, J.P. The roots of pedology: A response to "Pedology, a field or a laboratory science?". Soil Sci. Soc. Am. J, , v.53, p. 1920-1921, 1989.

BIGARELlA, J. J., MOUSINHO, M. R. ; DA SILVA, J. X. Considerações a respeito da evolução das vertentes. Boletim Paranaense de Geografia, v. 16 e 17 , p. $85-116,1965$ a.

BIGARELlA, J. J., MOUSINHO, M. R. ; DA SILVA, J. X. Pediplanos, Pedimentos e seus Depósitos correlativos no Brasil. Boletim Paranaense de Geografia, v.16 e 17, p. 117-151., 1965b.

BIGARELLA, J. J.; MOUSINHO, M. R. Contribuição ao estudo da formação Pariquera-Açu ( estado de São Paulo). Boletim Paranaense de Geografia, v. 16 e 17, p. 17- 41,1965.

BIGARELLA, J. J., MOUSINHO, M. R. ; DA SILVA, J. X. Considerações a respeito dos terraços fluviais, rampas de colúvio e várzeas. Boletim Paranaense de Geografia, v. 16 e 17, p. 153-197, 1965c.

BIGARELLA, J. J.; BECKER, R. D.; SANTOS, G. F. dos. Estrutura e origem das paisagens tropicais e subtropicais. v. 01. Florianópolis: Ed. UFSC, 1994. 424p.

BIRKELAND, P.W. Pedology, weathering and geomorphological research. New York:Oxford Univ. Press, 1974. 242p. 
BIRKELAND, P.W. Soil and Geomorfology. New York: Oxford Univ. Press, 1984. $372 p$.

BOULET, R. Análise estrutural da cobertura pedológica e topografia. In: CONGRESSO BRASILEIRO DE CIÊNCIA DO SOLO, 21, Campinas, 1987. Resumos. Campinas: SBCS, 1987. P. 79-90.

BOULET, R.; KOHLER, N. C.; MALTA, I. M. ; FILIZZOLA, H. F. Estudo da cobertura pedológica de uma vertente adjacente à uvala do conjunto cárstico da Lapa Vermelha Anais de Pedro Leopoldo (MG). In: CONGRESSO ABQUA, 3, Belo Horizonte, 1992.. Belo Horizonte: ABEQUA, 1992. p. 59 - 64.

BOULET, R.; PESSENDA, L.C.R.; TELLES, E. C. C.; MELFI, A. J. Une évaliation de la vitesse de l'accumulation de matiére par la faune du sol. Exemple des latosols de versantes du lac Campestre, Salitre, Minas Gerais, Brésil. C. R. Acad. Sci. Paris, t.320, Paris, sér. IIa, p. 287-294, 1995.

BOWNT, T. M. ; KRAUS, M. J. Time-stratigrafic reconstruction and integration of paleopedologic, sedimentologic and biotic events. Palaios, v.8, n. 1, p. 68-80, 1993.

/ Resumo em CAB Abstracts on CD-ROM, 1993/

BREWER, R. Fabric and Mineral Analysis of Soil. New York:Robert E. Krieger Publishing Company, 1976. 482p.

BRINKMAN, R. Ferrolysis, a hidromorphic soil forming process. Geoderma, v. 3, p. 199-206, 1969/1970.

BUCKMAN, H. O. ; BRADY, N. C. Natureza e Propriedades dos Solos. Rio de Janeiro: Freitas Bastos, 1968. 594p.

BUOL, S. W. HOLE, F. D. ; McCRACKEN, R.J. Soil genesis and classification. Ames: Iowa State Univ. Press, 1980. 360p.

BUSHEEJ. Potassium-argon ages of some alkaline rocks from Southern Brasil. Berkeley, 1974. 175p. Thesis ( Ph. D. ) University of California.

CAILLEUX, A.; TRITICART, J. Zonas fitogeográficas e morfoclimáticas do Quaternário do Brasil. Notícia Geomorf., v. 6, n. 12, p. 43 - 49, 1959. 
CALVO, S. S.; PENRTHREE, P. A. Tectonic geomorphology of Quaternarie faut scarps, Santa Rita Mountains, southeasten Arizona. Abstracts, Geological Society of America, v.13, n.2, p.47, 1981. / Resumo em CAB Abstracts on CD-ROM/

CAMARGO, M.N.; HIRANO, C.; FREITAS, F.G. de; JACOMINE, P.K.T.; ANTUNES, F. dos S.; SILVEIRA, C.O. da ; BENNEMA, J. Levantamento dos Solos da Região de Influência do Reservatório de Furnas. Rio de Janeiro: Ministério da Agricultura: 1962, 462p.

CAMARGO, M. N.; KAMPF, N. ; KLAMT, E. Sistema Brasileiro de Classificação de Solos. Rio de Janeiro: SNLCS/EMBRAPA, 1987. 35p. (Boletim Informativo 15).

CAMPOS, J.C. de; LANDGRAF, P.R.C. Análise da cobertura florestal das bacias hidrográficas dos Rios Cabo Verde e Machado, no Sul de Minas Gerais. In: CONGRESSO FLORESTAL BRASILEIRO, 6, Campos do Jordão, 1990. Resumos. São Paulo: Sociedade Brasileira de Silvicultura, 1990. p.28.

CARMO, D.N.; CURI, N. ; RESENDE, M. Caracterização e gênese de latossolos da região do Alto Paranaíba (MG). R. Bras. Ci. Solo, v. 8, n. 2, p. 235-240, 1984.

CARVALHO, A. P. de LARACH, J. O. I.; JACOMINE, P.K.T. ; CAMARGO, M.N. Critérios para distinção de classes de solos e de fases de unidades de mapeamento. Normas em uso pelo SNLCS. Rio de Janeiro: SNLCS/EMBRAPA, 1988. 67p. (Documentos 11).

CARVALHO, A. LEPSCH, I.F.; OLIVEIRA, J.B.; VALADARES, J. e ROTTA, C.L. Levantamento pedológico semi-detalhado do município de Atibaia (SP). Bragantia, v. 34, n. 1, p. $1-58,1975$.

CARVALHO, A. e ROTTA, C. L.Estudo das formações superficiais do município de Atibaia (SP). Boletim Paranaense de Geografia, Curitiba, n. 49, p. 5-22, jan. 1974.

CASTRO, S. S. Impregnação de amostras de solo para confecção de lâmina delgada. B. Inf. da Soc. Bras. Ci. do Solo, v.10, n.2, p.44, 1985. 
CASTRO, S. S. Sistemas de transformação pedológica em Marilia, SP: B latossólicos e B texturais. São Paulo, 1989. 274p. Tese ( Dr. ). Faculdade de Filosofia, Letras e Ciências Humanas da Universidade de São Paulo .

CETEC. Caracterização ambiental da bacia do Rio das Mortes - MG.Belo Horizonte: CETEC / COPAM, 1989. V. 1-4 (Relatório técnico Final, tapa 1).

CHAPMAN, S. L. \& HORN, M. E. Parent material uniformity and origin of silty soils in northwest Arkansas based on zirconium-titanium contents. Soil Sci. Soc. Am. Proc., v.32, p.265-271,1968.

CHAUVEL, G.; BOCQUIER, G. ; PEDRO, G. La stabilite et la transformation de la microestruture des sols rouges ferralitiques de casamance (Senegal). Analyse microscopique et donnés experimentales. In: INT. WORK. MEET. SOIL MICROMORPHOL., 5 , Granada, 1978. Anais. Granada: Universidade de Granada,1978. p. 779-813.

CHAUVEL, A. Recherches seu la transformation des sols ferralitiques dans la zone tropicauxs à soisons contrastees. These Sci. Starboug (1976) et Trav. et Doc. ORSTOM, 62, 532p. 1977.

CHOUDHRI, A., FIORI, A. P. \& BETTEN COURT, V. da S. Charnockitic gneisses and granulites of the Botelhos region, Southern Minas Gerais. In : CONGR. BRAS. GEOL., 30, Recife, 1978. Anais. Recife: SBG, 1978. v. 3, p. 1236-1249.

CHRISTOFOLETTI, A. Geomorfologia. São Paulo:Ed. Edgard Blucher Ltda, 1982. 188p.

COOPER, M. Estratigrafia e pedogênese de uma sequência de solos com B latossólico e B textural em Piracicaba-SP. Piracicaba, 1996. 125p. Dissertação ( M. S. ) Escola Superior de Agricultura Luís de Queiróz- USP.

CURI, N.; FRANZMEIER, D. P. Toposequence of oxisols from the Central plateau of Brasil. Soil Sci. Soc. Am. J., v.48, p.341-346, 1984.

CURI, N. Lithosequence and toposequence of Oxisols from Goiás and Minas Gerais, Brazil. West Lafayette, 1983. 158p. Thesis ( Ph. D. ) Purdue University. 
CURI, N.; LIMA, J.M. de; ANDRADE, H. ; GUALBERTO, V. Geomorfologia, física, química e mineralogia dos principais solos da região de Lavras (MG). Ciênc. Prát, Lavras, v. 14, n. 13, p 297 - 307, set/dez. 1990.

DABIN, B. Curso sobre matéria orgânica do solo. Parte I. Análise dos compostos húmicos do solo. Piracicaba : CENA, 1976. 55p. (Apostila).

DANIELS, R. B. Pedology, a field or a laboratory science? Soil Sci Soc. Am. J., v.52, p. 1518- 1519, 1988.

DANIELS, R. B. ; GAMBLE, E. E. The edge effect in some ultisols in the North Caroline Coastal Plain. Geoderma, , v. 01, p. 117 - 124, 1967.

DANIELS, R.B.; GAMBLE, E.E. ; CADY, J.G. Some relations among coastal plain soil and geomorphic surfaces in North Carolina. Soil Sci Soc. of Am. Proceeding, , v. 34, n. 41, p. 648-653, 1970.

DANIELS, R.B.; GABLE, E.F. ; CADY, J.G. The relation between geomorphology an soil morphology an genesis. Advances in Agronomy, v. 28, p. 51 - 87, 1971.

DANIELS, R. B. ; HAMMER, R. D. Soil Geomorphology. New York: John Wiley e Sons, 1992. 236p.

DARLYMPLE, J.; BLONG, R. J. ; CONACHER, A. J. A hypothetical nine unit land surface model. Zeitshrift fur Geomorphologie, v. 12, n. 1, p. 60-76, 1968.

DE BOER, M.W.H. Landforms an Soil in Eastern Surinam Wageningen : Wageningem Centre for Agricultural Publishing and Documentation, 1972. 168p.

DELGADO-CALVO-FLORES, R.; BARAHONA, E.; LINARES,J. Soil forming factors of the upper basin of the Dilar river ( Sierra Nevada). Anales de Edafologia $y$ Agrobiologia, v.41, n.12, p. 21-37, 1982. / Resumo em Cab Abstrets on CDROM, 1983 /

DE MARTONNE, E. Mapa do relevo. Anuário Geográfico do Brasil, Ano I. Rio de Janeiro : Conselho Nacional de Geografia, 1953. p. 149-152.

DEMATTÊ, J. L. I. ; HOLOWAY CHUCK, N. Solos da Região de São Pedro, Estado de São Paulo. I. Propriedades gramulométricas e químicas. R. Bras. Ciência do Solo, v. 1, n. 2 - 3, p. 104 - 107, 1977. 
DIAS-FERREIRA, R. P.; QUEIROZ NETO, J. P., COUTARD, J. P. ; PELLERIN, J. Estude preleminare du Quaternaire de la Région de São Pedro (São Paulo, Brasil). An. Acad. Brasileira de Ciência, Suplemento, São Paulo. v. 47, p. 317-326, 1975.

DIJ KERMAN, J.C. ; MIEDEMA, R. An Ustult-Aquet-Tropept Catena in Sierra Leone, West. Africa. I. Characteristics, Genesis and classification. Geoderma, v. 42, p. 1-27, 1988.

DORMAAR, J. F. ; FOSTER, R.C. Nascent aggregates in the rhizosfere of perennial rygrass (Lolium perenne L.). Canadian Journal of Soil Science, v. 71, n. 4, p. $465-474,1991$.

DREES, L. R. ; WILDING, L. P. Elemental variability within a sampling unit. Soil Sci. Soc. Am. Proc., v.37, p.82-87, 1973.

DUBROEUCQ, D. ; GEISSERT, D. ; MORENO, P.; MILLOT,G. Soil evolution and plant communities in coastal dunes near Veracruz, México. Cah. ORSTOM, sér. Ped.,v.27, n.2, p.237-250, 1992.

EBERT, H. Mapa geológico preliminar da parte Sul do Estado de Minas Gerais e adjacências. Relatório anual do Diretor, 1956. Divisão de Geologia e Mineralogia do D.N.P.M, Rio de Janeiro, Ministério de Agricultura, 1956.

EBERT, H. Ocorrência des fácies granulíticas no Sul de Minas Gerais e em áreas adjacentes, em dependência da estrutura orogênica: hipóteses sobre sua origem. An. Acad. Bras. Ciências, Rio de Janeiro,v. 40, p. 215-229, 1968.

ELLERT, R. Contribuição à geologia do maciço alcalino de Poços de Caldas. São Paulo: Faculdade de Filosofia, Ciências e Letras, Geologia, 1959. 63p. (Boletim Técnico 237 ).

EMPRESA BRASILEIRA DE PESQUISA AGROPECUÁRIA. Mapa de Solos do Brasil. Escala de 1:5.000.000. Rio de Janeiro : EMBRAPA/SNLCS, 1981.

EMPRESA BRASILEIRA DE PESQUISA AGROPECUÁRIA. Serviço Nacional de Levantamento e Conservação de Solos. Manual de Métodos de Análise de Solos. Rio de Janeiro: Ministério da Agricultura, 1979. n.p. 
EMPRESA BRASILEIRA DE PESQUISA AGROPECUÁRIA. Serviço Nacional de Levantamento e Conservação de Solos. Sistema Brasileiro de Classificação de Solo. $2^{a}$ aproximação. Rio de Janeiro: EMBRAPA/SNLCS, 1981a. 107p.

ERGENZINGER, P. Regional erosion: rates and scale problems in the Buonamico basin, Calábria. Catena, v.13, p. 97-107, 1988.

ESCHENBRENNER, V. Contribution des termites à la micro-agregation des sols tropicaux. Cah. ORSTOM, ser. Ped.., XXII, v. 4, p. 387 - 408, 1986.

ESCHENBRENNER, V. Les globules des sols de Cote d'lvoiré. Nature et origine en mileu ferralitigue. Modalites de leur concentration. Rete des termites. ORSTOM, Paris, TDM, 39, p. 198-282, 1988.

ESCHENBRENNER, V. Termite activity and soil morphology in tropical áreas ( compact disc).In: CONGRESSO LATINO AMERICANO DE CIÊNCIA DO SOLO, 30 , Água de Lindóia, 1996. Solo-Suelo96: trabalhos. Piracicaba: SBCS/SLCS, 1996.

ESPEN, P.; NULLENS, H.; ADAMS, F. A. A computer analysis of X-ray fluorescence spectra. Nuclear Instruments and Methods, v.142, p. 243-250, 1977.

ESPEN,P. ; JANSSENS, P.; SWENTER, I. Axil X-ray analysis software. Users manual. Version 3.1. Camberra: Benelux, 1991. 72p.

ESWARAN, H. ; SYS, C. Argillic horizon in LAC soils: formation and significance to classification. Pedologie, Ghent, v. 29, p. 175-190, 1979.

E.U.A. Soil Survey Staff. Soil Taxonomy: A Basic System of Soil Classification for Making and Interpreting Soil Surveys. Agric. Handb. $\mathrm{n}^{\circ} 436$, v.5, Government Printing Office, Washington, D.C. 330p. 1975.

FANIRAN, A. ; JEJE, L. K. Humid tropical geomorphology. A Study of the geomorphological processes and landforms in warm humid Climates. New York: Longman Inc., 1983. 332p.

FELIX-HENNINGSEM, P. Mesozóic-Tertiary weatering and formation on slates of the Renish Massif, Germany. Catena, v.21, n.2-3, p. 229-242, 1994. 
FERREIRA, M. M. Influência da mineralogia nas propriedades fisicas de latossolos brasileiros. Viçosa, 1988. 89p. Tese ( Dr. ) Universidade Federal de Viçosa.

FLACH, W. CADY, J. G. e NETTELTON, W. D. Pedogenitic alteration of highly weathered parent material.In: INT. CONGR. SOIL. SCI., 9, Adelaide, 1968. Anais. Adelaide: SICS, 1968. p. 343-351.

FILIZZOLA, H.F. ; BOULET, R. Une évaluation de la vitesse de l'érosion géochimique à partir de l'etude de dépressions fermées sur roches sedimentaires quartzokaoliniques au Brésil. C.R. Acad. Sci. Paris 316, Paris, sér. II. p. 693-700, 1993a.

FILIZZOLA, H. F. ; BOULET, R. Evolution et ouverture des depressions fermees sur substrat quartzo-kaolinique dans le Bassin de Taubaté - São Paulo, Bresil In: CONGRESSO INTERNACIONAL DE GEOMORFOLOGIA, 30, Hamilton, 1993. Anais. Hamilton : SIGE, 1993b. P.87-99.

FIORI, A. P. Geologia da região de Pouso Alegre-Machado : análise estrutural dos dobramentos superpostos. São Paulo, 1979. 200p. Tese (Dr.) Instituto de Geociências-Universidade de São Paulo.

GAVANDE, S. A. Física de suelos; princípios Y aplicaciones. México: Editorial Limusa, 1976. p. 87 - 95.

GERRARD, J. Soil Geomorphology: one integration of pedology and geomorphology. London: Chapman e hall ed, 1992.269p.

GERRARD, J. Soil Geomorphology: present dilemmas and future challenges. Geomorphology, v. 7, p. $67-84,1993$.

GILE, L.H. ; HAWLEY, J.W. Periodic sedimentation and soil formation on an Alluvial-Fan Piedmont in Southern New-Mexico. Soil Sci. Soc. Am. Proc, Madison, v.30, n.2,p.261-268, 1966.

GILE, L.H. Causes of soil boundary in an arid region: I. Age and parent materials. Soil Sci. Soc. Am. Proc. , v. 39, n. 2, p. 314-323, 1975a.

GILE, L. H. Causes of soil boundary in an arid region : II. Dissection, moisture and faunal activity. Soil Sci. Soc. Am. Proc. , v. 39, n. 2, p. 324-330, 1975 b. 
GOLFARI, L. Zoneamento Ecológico do Estado de Minas Gerais para Reflorestamento. Belo Horizonte: IBDF, 1975.65p

GRASSE, P. P. Termitologie, Anatomie, phisiologic, biologic systematiques des termites t2. fondation des rociéter-contruction. Paris: Masson ed., 1984. 676p.

GRASSE, P. P. Termitologie Anatomie, phisiologic, biologie systematiques des termites t. 3. Comportamentu, sociability, ecologie, evolution, sistematique. Paris: Masson ed. 1986. 715p.

GRIFFITH, G. Laterita Vesicular. Nature, Londres, V. 171, p. 530, 1953.

GUERRA, A. J. T. e CUNHA, S. B. da. Geomorfologia: uma atualização de bases e conceitos. 2 ed. Rio de Janeiro: Bertrand Brasil, 1995. 472p.

HALL, G.F. Pedogenesis and soil toxonomy. I. Concept and interactions. New York: Elsenvier Sci. Pub., 1983. p. 117-140.

HAMA, M. Geocronologia. In: KAEFER, L. Q. et alii. Projeto Sapucaí, Estados de São Paulo, Rio de Janeiro e Minas Gerais; relatório final de geologia. Brasilia: DNPM, 1979. 299p. (Série Geologia, 4 Seção Geologia Básica, 2).

HASUT, Y. e ALMEIDA, M. A. Aspectos estruturais na geomorfologia da área cristalina de São Paulo e Paraná - IN: CONGRESSO BRASILEIRO DE GEOLOGIA, 30, Recife, 1978. Anais. Recife: SBG-PE, 1978.

HASUI, Y. HERBERT, H. D. e COSTA, J.B.S. Estruturação de extremidade oriental da chamada Cunha de Guaxupé: dados preliminares. In: CONGRESSO BRASILEIRO DE GEOLOGIA, 36 , Natal, 1990. Anais. Natal: Sociedade brasileira de Geologia, 1990a. p. 2296 - 2308.

HASUY, Y. Neotectônica e aspectos fundamentais da tectônica ressurgente no Brasil. Bol. Soc. Bras., Geologia. Núcleo Minas Gerais, Belo Horizonte, v. 11, p. 131, 1990.

ISBELL, R. F. The argilic horizon concept and its application to the classification of tropical soils. In : PROCEEDINGS CONFERENCE ON CLASSIFICATION OF TROPICAL SOILS, Kuala Manpur, 1980. Resumos. Kuala Manpur: Malasyan Society of Soil Science, 1980. p.150-157. 
JOHNSON, D. L. Biomantle evolution and the redistribuition of earth materials and artifacts. Soil Science, v. 149, n. 2, p. 84-101.1990.

JONG van LIER, Q. de; VIDAL-TORRADO, P. PHI: Programa de microcomputador para análise estatística da granulometria de sedimentos. R.Bras. Ciência do Solo, v. 16, n.3, 277-281,1992.

JACKSON, M. L. Soil Chemical analysis. Advanced course. Madison: Publicado pelo autor, 1969. 894p.

JACOB, J.S. ; NORDT, L.C. Soil and Landscape Evolution: A Paradigm for Pedology. Soil Sci. Soc. Am. J., v. 55, p. 1194, 1991.

JMENEZ RUEDA ; DAMATTÊ, J. L. I. Solos originados de lamitos da formação Marilia (Grupo Bauru) da região de Monte Alto, SP. R. bras. Ci. Solo, v. 12, n. 2, p.161-170, 1988.

KAR, A. Lineament control on channel behaouviour during the 1990 flood in the southeasten Thar Desert. International Journal of Remoting Sensing, v.15, m.13, p. $2521-2530,1994$.

KING, L. Canons of landscape evolution. Bulletin of the Geological Society of America., New York, v. 64, p. 721 - 751, 1963.

KING, L. A Geomorfologia do Brasil Oriental. Rev. bras. Geogr., , v. 18, n. 2,147 256, 1956.

LECOMTE, P. Stoneline profiles: importance en geochemical exploration. Journ. Geochem. Exploration, v. 30, p. 35 - 61, 1988.

LEE, K.E. \& WOOD, T.G. Termites and Soils. London: Academic Press, 1971. N.p.

LEINZ, V.; AMARAL, S. E. do. Geologia Geral. 9 ed. São Paulo, Ed. Nacional, 1985. $398 \mathrm{p}$.

LEMOS, R. C. de; SANTOS, R. D. Dos. Manual de descrição e coleta de solo no campo. Campinas: SBCS/SNLCS, 1984. 46p. 
LEPSCH, I. F.; BUOL, S.W. Oxisol Landscape relationships in Brazil. In: INTERNATIONAL SOIL CLASSIFICATION WORK SHOP., 13 , Campinas, 1986. Part 1: papers. Campinas: SNLCS / EMBRAPA, USDA, University of Puesto Rico, 1986. p. $174-189$.

LEPSCH, I.F.; BUOL, S. W. ; DANIELS, R.B. Soil landscape relationships in the occidental plateau of São Paulo, Brazil: I Geomorphic surfaces and soil mapping units. Soil Sci. Soc. Am. J., v. 41, p. 104-109, 1977 a.

LEPSCH, I. F.; BUOL, S. W. ; DANIELS, R.B. Soil landscape relationships in the occidental plateau of São Paulo, Brazil: II Soil morphology, genesis and classification. Soil Sci. Soc. Am. J., v. 41, p. 109 - 115, 1977 b.

LEPSCH, I. Superficies Geomorfológicas e depósitos superficiais neocenozóicos em Echaporã, SP. Boletim Paulista de Geografia, v. 53, p. 5 - 34, 1977.

LEPSCH, I.F. ; BUOL, S.W. Investigation in an Oxisol-Ultisol toposequence in São Paulo State, Brazil. Soil Sci. Soc. Amer. Proc; v. 38, p. 421 - 496, 1975.

LICHTE, M. Arid processes in the SE-Brazilian relief evolution during the last glacial. Bol. IG-USP, Publ. Esp. , São Paulo, v. 8, p. 201 - 211, 1991.

LICHTE, M. Stonelines as a definite cyclic feature in southeast Brazil: A geomorphological and pedological case study. Pedologie, Ghent, XL-1, p. 101-109. 1990.

LIMA, P.C.; CURI, N. ; LEPSCH, I. F. Terminologia de micromorfologia do solo B. Inf. Soc. bras. Ci. Solo, v. 10, n. 2, p. 33 - 43, 1985.

LIU, S. Et al. . Preliminaries study of properties of palaeo-red-soils in southwest Sichuan. Journal of Sichuan-Agricultural-University, v.8, n. 4, p. 273-283, 1990. /Resumo em CAB Abstracts on CD-ROM, 1990)/

LOVELOCK, J. E. A new lock of life on Earth. New York: Oxford. Uni. Press, 1979. $157 \mathrm{p}$. 
LU, J. G. Effect of neo-tectonic movement on soil formation and soil development in the Yangtzé delta. Acta-Pedológica-Sinica, v. 19, n.1, p. 1-12, 1983. / Resumo em CAB Abstracts on CD-ROM/

LUCAS, Y.; LUIZÃO, F. J.; CHAUVEL, A.; ROUILLER, J. ; NAHON, D. The relation betwen biological activity of the rain forest and mineral composition of soils. Science, v. 260, p. $521-523,1993$.

LUCAS,Y.; SOUBIES, F.; CHAUVEL , A.; DESJARDINS, T. Estudos do solo revelam alterações climáticas da Amazônia. Ciência Hoje,, v.16, n.93, p.36-39, 1993.

LUZ, L. R. Q. P.; SANTOS, M. C. dos ; MERMUT, A. R. Pedogênese em uma topossequência do semi-árido de Pernambuco. R. Bras. Ci. Solo, v. 16, n.1, p. 95 $102,1992$.

MACEDO, J. ; BRYANT, R.B. Morphology, minerology and genesis of a hidrosequence of oxisols in Brasil. Soil Sci. Soc. Am. J., v. 51,P. 690-698, 1987.

MAGALHÃES JÚNIOR, A. P.; MAGNIC, M. V. e MARQUES, M. R. Análise e mapeamento geomorfológico da região a Oeste de São João Del Rei. Belo Horizonte, 1990. 102p. Monografia ( Graduação) Faculdade de Geografia-UFMG.

MARQUES JÚNIOR, J.; LEPSCH, I. F. ; FERRAUDO, A. S. Neotectônicas e distribuição dos solos no Planalto Ocidental Paulista ( Compact disc). In: CONGRESSO BRASILEIRO DE CIENCIA DO SOLO, 26, RIO DE jANEIRO, 1997. Informatização, Globolização, uso do solo. Trabalhos. Rio de janeiro: SBCS, 1997.

MARSHAL, C. E. A petrographic method for the study of soil formation processes. Soil Sci. Soc. Am. Proc. ,V.5, p. 100-103, 1940.

MC FARLANE, M. J. ; POLLARD, S. Some aspects of stone-lines and dissolution fronts associated with regolith and Dambo profiles in parts of Malawi and Zimbabwe. Geo-Eco-Trop., v. 11, n. 1 - 9, p. 23 - 35, 1989.

MARTINEZ - DELCLOS, Y. e MARTINELL, J. The oldest know record of social insects. J. Paleontology, v. 69, n. 3, p. 594-599, 1995. 
MEIS, M. R. M. A morfologia de rampas e terraços no Planalto Sudeste do Brasil. Médio Vale do Rio Doce. Finisterra, v. 11, n. 26, p. 201 - 210, 1978.

MELO, M. S. ; PONÇANO, W. L. Gênese, distribuição e estratigrafia dos depósitos cenozóicos no Estado de São Paulo. São Paulo: IPT, 1983. 74p. ( Série Monografias, 9).

MELO, W. J. Matéria orgânica do solo. Jaboticabal: UNESP, 1994. 68p. (Apostila).

MELO, M. S. A formação Rio Claro e depósitos associados: sedimentação neocenozóica na Depressão Periférica Paulista. São Paulo, 1995. Tese ( Dr. ) Instituto de Geociências-USP.

MICHAEL, P. et al. The landforms of Tailand: ideas about their genesis and influence on soil distribuition. In: INTERNATIONAL SIMPOSIUM ON SOIL, GEOLOGY AND LANDFORMS, Bangkok , 1982. Nc-10, p.14. /Resumo em CAB Abstracts on CDROM/

MIKLÓS, A. A. de W. Byodinamique d'une couverture pedologique dans la region de Botucatu, Brésil. France ,1992. 438p. Thése ( Dr.) Université Paris VI.

MIKLOS, A. A. de W. ; MIOCQUE, P. Horizontes latossólicos, horizontes sômbricos e " stone-line ": organizações de origem biológica-fauna do solo. In: CONGRESSO BRASILEIRO DE CIÊNCIA DO SOLO, 24, Goiânia, 1993. Cerrados: Fronteira Agrícola do Século XXI .Resumos .Campinas: SBCS,1993. v.2. p.327-328.

MIKLÓS, A. A. de W. A contribuição da fauna do solo na gênese de latossolos e de "Stone - lines"( Compact disc ). In: CONGRESSO LATINO AMERICANO DE CIÊNCIA DO SOLO,13, Águas de Lindóia, 1996. Solo-suelo 96: trabalhos. Piracicaba:SBCS/SLCS, 1996.

MILLOT, G. Geologie des argiles. Masson: Paris, 1964. 499p.

MINAS GERAIS. Mapa Geológico do Estado de Minas Gerais. Escala de 1:1.000.000. Minas Gerais: Instituto de Geo-Ciências Aplicadas da Secretaria do Planejamento e Coordenação Geral, 1976. 
MINAS GERAIS. Secretaria de Ciência e Tecnologia. Diagnóstico Ambiental de Minas Gerais: Belo Horizonte: COPAM / CETEC, 1983. 242p.

MIOTO, J. A. Mapa de risco sísmico do sudeste brasileiro. São Paulo: IPT, 1984. (Monografia, 10 - ITP, 1563).

MIOTO, J. A. Tentativa de zoneamento sísmico do sudeste brasileiro. Bol. Soc. Bras. Geologia - Núcleo Minas Gerais, n. 11, 1990. p. 33-45.

MIYASAKA, S. et al. Adubação orgânica, adubação verde e rotação de culturas no estado de São Paulo. São Paulo: Fundação Cargil, 1983. 138p.

MODENESI-GAUTIERI, M. C.; TOLEDO, M. C. De. Wheatering and the formation of hillslope deposits in tropical higlands of Itatiaia -Southeastern Brasil. Catena, v. 27, p. 81-103, 1996.

MONIZ, A.C. ; BUOL, S.W. Formation od an Oxisol-Ultisol Transition in São Paulo, Brasil: I. Double Water Flow Model of Soil Development. Soil Science Soc. Am.Journal, v. 46, p. 1228 - 1233, 1982.

MULLER, J. P. Microestruturation des structichrons rouges ferralitiques à l'amont des modelés convexos (Centre-camerum).Aspects morphologiques. Cah. ORSTOM, ser. Péd., v. 15, n. 3, p. 239 - 258, 1977.

MULLER, J.P. Sequence of vertical evolution in the microorganization of loose ferralitic materials in the Cameroons. In: INTERNACIONAL WORK. MEET. SOIL MICROMORFOLOGY, Londom,1981..Anais. London: A.B. Academic Pub. 1981.P.1-10.

NETTLETON, W. D.; ESWARAN, H.; HOLZEY, C. S.; NELSON, R. E. Micromorphological evidence of clay translocation in poorly dispersible soils. Geoderma, v. 40, p. 37-48, 1987.

OLIVEIRA, M. A.T.Petrologia das rochas metamórficas da região de São José do Rio Pardo (SP). Rev. Bras. Geol, v. 3, p. 257-278, 1973.

OLIVEIRA, M. A. T. e ALVES, F. R. Geologia e Petrografia da região de Caconde (SP). In: CONGRESSO BRASILEIRO DE GEOLOGIA,18, 1974, Porto Alegre. Anais.Porto Alegre: SBG,1974. v. 3, p. 133-143. 
PEDRO, G. Geóchime, mineralogie et. organisation des sols Aspects coordennés des problemes pédogenetiques. Cah. ORSTOM, ser. Ped., v. 23, n. 3, p. $169-185$, 1987.

PELLERIN, J. ; QUEIROZ NETO, J. P. Morfogênese e pedogênese no córrego da invernada (Marilia-SP).In: CONGRESSO DA ABEQUA, 3 , Belo Horizonte, 1992.Anais. Belo Horizonte: ABEQUA, 1992. p.111- 120.

PENTEADO, M.M. Geomorfologia do Setor Centro Ocidental da Depressão Perférica Paulista . Rio Claro, 1968. 86p. Tese (Dr. ) Faculdade de Filosofia, Ciências e Letras de Rio Claro.

PENTEADO, M. M. Fundamentos de geomorfologia. IBGE. Biblioteca Geográfica Brasileira, Série D. Publicação n 3. Rio de Janeiro, 1974. 158p.

QUEIROZ NETO, J.P. e CASTRO, S. F. Formações superficiais e Latossolo Vermelho Amarelo Húmico da área de Bragança Paulista (SP). In: CONGRESSO BRASILEIRO DE GEOLOGIA, 18, Porto Alegre, 1974. Anais. Porto Alegre: SBG, 1974. p. 65-83.

QUEIROZ NETO, J.P. ; JOURNAUX, A. (Coordenadores). Carta geomorfológica de São Pedro (SP). Sedimentologia e Pedologia. Sào Paulo: Instituto de Geografia/USP, 1978. v. 12,p. 1-33.

QUEIROZ NETO, J. P.; CASTRO, S. S.; FERNANDES BARROS; O. N. MANFREDINI, S.; PELLERIN, J.; RUELLAN, A. ; TOLEDO, G. S. Um estudo de dinâmica de solos: formação e transformação de perfis com horizonte $B$ textural. In: CONGRESSO BRASILEIRO DE CIÊNCIA DO SOLO, 18, Salvador, 1980. Resumos. Campinas: Sociedade Brasileira de Ciência do Solo, 1981.

RABENHORST, M. C. ; WILDING, L. P. Pedogenesis on the Eduards Plateau, Texas: I. Nature and continuity of parent material. Soil Sci. Soc. Am. J. , v. 50, p. 678-687, 1986.

RADAMBRASIL, Levantamento dos recursos naturais: geologia, geomorfologia, pedologia, vegetação e uso potencial da terra. Folhas SF. $23 / 24$, Rio de Janeiro/Vitória. Rio de Janeiro: Ministério das Minas e Energia, 1983. 780p. 
RANZANI, G.; PENTEADO, M.M. ; SILVEIRA, J.D. Concreções ferruginosas, paleossolo e as superficies de cimeira do Planalto Ocidental Paulista. Geomorfologia, v. 1, p. $1-28,1972$.

RESENDE, M. Mineralogy, chemistry, morphology and geomorphology of some soils of the Central Plateau of Brazil. West Lafayette, 1976. 218p. Thesis (Ph. D.) Purdue University

RESENDE, M. Pedologia. Viçosa; Impresa Universitária, 1980. 100p.

RESENDE, M.; CURI, N.; RESENDE, S.B. \& CORREA, .F. Pedologia: base para distinção de ambientes. Viçosa: NEPOT, 1995. 304p.

RESENDE, M.; CURI, N.; SANTANA, D. P. Pedologia e Fertilidade do Solo: Interações e Aplicações. Brasilia: MEC/ESAL/POTAFOS, 1988. 81p.

RETALLACK, G. J. Late Eocene and Oligocene paleosols from Badlands National Park South Dakota. Special-Paper, Geological Society of America, n. 93. 82p., 1983

REZENDE, S.B. Geomorphology, mineralogy and genesis four fom soils on genesis in southeastern Brasil. West Lafayette, 1980. Thesis ( $\mathrm{Ph}$. D.) Purdue University. RIBEIRO, F. S.; SAADI, A. Os terraços do baixo vale do Rio Carandaí. (MG): possível significado. In: SIMPÓSIO DE GEOGRAFIA FÍSICA APLICADA, 1989, Nova Friburgo. Anais. Nova Friburgo: IG / UFRJ, 1989. p. 131-148.

ROSS, J. L. S. O relevo brasileiro, as superficies de aplainamento e os níveis morfológicos. Rev. do Departamento de Geografia da USP, v. 5, p. 7-24. 1991.

RUHE, R.V. Geomorphology. Boston: Houghton Mifflin pub., 1975. 327p.

RUHE, R.V.; DANIELS, R. B. e CADY, J.G. Landscape evolution and soil formation in south wester Iowa. USDA Technical Bulletin 1349. 1967.

SAADI, A. Um "Rift" neocenozóico na região de São joão del Rei (MG). Bol. Soc. Bras. Geol.- Núcleo Minas Gerais , n. 11, 1990, p.63-79.

SAADI, A. Eventos tectono-sedimentares na bacia neocenozóica do Rio das Mortes, região de São João Del Rei - MG . Bol. Soc.Bras.Geol. Núcleo Minas Gerais, n. 11,1990 a, p. $81-99$. 
SAADI, A. Ensaio sobre a morfotectônica de Minas Gerais. Belo Horizonte, 1991. 160p. Tese (Professor Titular) IGC-UFMG.

SALIK, J.; HERRERA, R. e JORDAN, C.F. Termitaria nutrient patchiness in nutrient deficient rainforest. Biotropica, v. 15, n. 1, p. 1-7.

SANCHEZ, P.A. Suelos del Tropico características y manejo . San José - IICA: 1991. $660 \mathrm{p}$.

SANFORD, R. L.; SALDARRIAGA, J.; CLARK, K. E.; UHL, C.; HERRERA, R. Amazon rain forest fires. Science, v. 227, n.46-82, p.53-55, 1985.

SANTOS, M. C.D.; ST ARNAUD, R.J. ; ANDERSON, D.W. Quantitative evalution of pedogenic changes in Boralfs (gray Luvisols) of East Central Saskatchewam. Soil. Sci. Soc. Am. J., v. 50, p. 1019 - 1041, 1986.

SANTOS, M. C. D., MERMUT, A.R. e RIBEIRO, M.R. Micromorfologia de solos com argila de atividade baixa no Sertão de Pernambuco. R. Bras. Ci. Solo, v. 15, n. 1, p. 83-91, 1991.

SCHAEFER, C. E. The microestruture of latosols as long-tem biotic constructs (Compact disc). In: CONGRESSO LATINO AMERICANO DE CIÊNCIA DO SOLO, 13, Águas de Lindóia, 1996. Anais. Piracicaba: SBCS/SLCS, 1996.

SCHOBBENHAUS FILHO, C. Carta Geológica do Brasil ao Milionésimo. Folha Goiânia SF22. Brasilia: DNPM, 1975.

SCHOBBENHAUS, C.; CAMPOS, D. de A.; DERZE, G. R. e ASMUS, H.E. Geologia do Brasil. Brasilia: DNPM, 1984. 501p.

SILVA, A. C.; LIMA, J. M. de ; CURI, N. Relação entre voçorocas, usos da terra, solos e materiais de origem na região de Lavras (MG). Revista Brasileira de Ciência do Solo, v. 17, n. 3, p. 459-464, 1993.

SILVA, C. L. da; JMENES-RUEDA, J. R.; HASUY, Y. Aspectos pedogenéticos na evolução de uma bacia tectônica do Quaternário (Compact disc). In: CONGRESSO BRASILEIRO DE CIÊNCIA DO SOLO, 26, Rio de Janeiro, 1997. Informatização, globalização, uso do solo: trabalhos. Rio de Janeiro: SBCS, 1997. 
SIQUEIRA, J. O.; FRANCO, A. A. Biotenologia do solo: Fundamentos e perspectivas. Brasila: MEC-ESAL-FAEP-ABEAS, 1988. 205p.

SIRKIN, L.; CONNALLY, G.; STUCKEERRATH, R. The west Mexican Coastal-Plain: estatigraphy and geologic history. Abstracts, Geological Society of America, v.13, n.2, p.106, 1981.

SOMBROEK, W. G.; SIDERIUS, W. Nitosols and their genesis. In: MEETING OF THE EASTERN AFRICAN SUB-COMMITTEE FOR SOIL CORRELATION LAND EVALUATION, 2, Addis Abeba, 1996. FAU: Addis Abeba, 1976. P.84-86 (World soils resourses reports, 47)

SOMBROEK, W. G. Soils with nitic attributes. In: CONGRÉS DE L'ASSOCIATION INTERNATIONALE DE LA SCIENCE DU SOL, 14, Tokyo, 1990. Anais. Tokyo: ISSC, 1990.

SOUBIÉS, F. Existence d'une phasé seche en Amazonie Brésilene par la presence de charbons dans le sols (6000-3000 ans BP). Cah ORSTOM, sér. Geol., v.11, n.1 p.133-148, 1980.

STEVENSON, F. J. Hymus chemistry. New York: John Willey and Sons, 1982. 443p.

STOCKING, M.A. Interpretation of Stone-lines. The South. African. Geograph. Journ. v. 60 , p. $121-134,1978$.

STOOPS, G. Le profil d'alteration au Bas-Congo (Kinshasa). Sa description e sa genèse. Pedologie, Ghent, v. 17, p. 60 - 65, 1967.

STOOPS, G. 1983. Micromorphology of the oxic horizon. In: BULLOCK , P.; MURPHY, C. P. (eds.)Soil Micromorphology Vol. 2: Soil Genesis. Berkhamsted: AB Academic publishers. p. 419-440. 1983.

STOOPS, G. ; BUOL S.W. Micromorphology of Oxisols. In: L.A. Douglas e M.L. Thompson (eds.), Soil Micromorphology and soil Classification. SSSA Publ. $\mathrm{n}^{\circ}$. 15. SSSA, Madison, WI (EUA). p. 105-119. 1985.

SUBRAHMANYAM, C. On the relation of gravity anomalies to geotectônics of the Precambrian terrains of South Indian Shield. J. Geol. Soc. Índia, v.19, p. 251$263,1978$. 
SUDOM, M. D. ; ARNAUD, R. J. St. Use of quartz, zirconium and titanium as indice in pedological studies. Can. J. Soil Science, v.51, p. 385-396, 1971.

SWARDT, A. M. J. Laterisation and landscape development in parts of equatorial Afríca. Zeit. fur Geom., n. 8, p. 313-333, 1964

TARDY, Y. Érosion. Encyclopeaedia Universalis, Paris, v. 8, p. 615 - 627, 1990.

TRAPNELL, C.G. ; WEBSTER, R. Microaggregates in red carths and related soils in East and Central Africa, their classification and occurence. J. of Soil Science, v. 37, p. $199-123,1986$.

TRICART, J. As relações entre a morfogênese e a pedogênese. Notícia Geomorfológica, v. 8, n. 15, 5-18, 1968.

TURCQ, B.; SUGUIO, K.; SOBIES, F.; SERVANT, M.; PRESSINOTTI, M.M.N. Alguns terraços fluviais do sudeste e do centro-oeste brasileiro datados por radiocarbono: possíveis significados paleoclimáticos. In: CONGRESSO ABEQUA, 1, Porto Alegre, 1987. Anais. Porto Alegre: ABEQUA, 1987. p. 379-392.

TURCQ, B.; SUGUIO, K.; MARTIN, L.; FLEXOR, J. M. Registros milenares nos sedimentos dos lagos da serra de Carajas. Ciência Hoje, Rio de Janeiro, v. 16, n.93, p.32-35, 1993.

TYLER, E.J.; BUOL, S.W. ; SANCHES, P.A. Genetic association of properties of soil an área in the upper Amazon Basin of Peru. Soil Sci. Soc. Am. Proc. v. 42, p.771-776.

VETTORI, L. Métodos de análise de solos. Rio de Janeiro, Ministério da Agricultura, 1969. 24p. (Boletim Téenico 7).

VIDAL TORRADO, P. Relações solo $x$ relevo em Mococa (SP); influência das características topográficas e posição na vertente nos atributos do solo. Piracicaba, 1989 . 205p. Dissertação (M. S.) Escola Superior de Agricultura "Luiz de Queiroz" - USP. 
VIDAL TORRADO, P.; MAZZA, J.A.; CASTRO, S.S.; DEMATTÊ, J.L.I. Micromorfologia e gênese de um Podzólico Vermelho Amarelo desenvolvido de sedimentos da formação Itararé no distrito de Tupi (Piracicaba-SP). In: CONGRESSO BRASILEIRO DE CIÊNCIA DO SOLO, 23, Porto Alegre, 1991. Resumos. Campinas: Sociedade Brasileira de Ciência do Solo, 1991. p.275.

VIDAL TORRADO, P. ; LEPSCH, I. F. Morfogênese dos solos de uma topossequência com transição $\mathrm{B}$ latossólico $\times \mathrm{B}$ textural sobre migmatitos em Mococa (SP). R. Bras. Ci. Solo. v. 17, n. 1, p. 109-119. 1993.

VIDAL TORRADO, P. Relações entre morfogênese e pedogênese no Distrito de Tupy (Piracicaba -SP). Piracicaba, 1994. 214p. Tese (Dr.) Escola Superior de Agricultura "Luiz de Queiroz"-USP.

VIDAL TORRADO, P.; LEPSCH, I.F.; CASTRO, S.S.; COOPER, M. ; PESSOTI,P. R.R. Pedogênese em uma catena com transição B latossolólico - B textural sobre sedimentos pelíticos em Piracicaba, SP. In: CONGRESSO BRASILEIRO DE CIÊNCIA DO SOLO, 25, Viçosa, 1995. Resumos expandidos. Campinas: Sociedade Brasileira do Solo, 1995. p. 1503 - 1505.

WERNICK, E.; OLIVEIRA, M.A.F.; KAWASHITA, K.; CORDANI, U.G.e DEHAL, J. Estudo geocromológico pelo método $\mathrm{Rb} / \mathrm{Sr}$ em rochas do Bloco Jundiaí e regiões adjacentes. Rev. Bras. Geol., v. 6, p. 125-135, 1976.

WERNICK E.; FIORI, A. P.; BETTE COURT, J. S.; CHOUDHURI, A. A tectônica rígida do fim do ciclo Brasiliano e sua implicação na estrutura da borda sul e sudoeste do Cráton do São Francisco: tentativa de um modelo preliminar. In: SIMPÓSIO CRÁTON DO SÃO FRANCISCO E SUAS FAIXAS MARGINAIS, Salvador, 1978. Anais.

WHITE, E. M. Soil age and texture in subsoil structure gênesis. Soil Science, v. 103 , p. $288-298$, apr. 1967.

WOLKOFF, B.; FLEXOR, J. M.; SANTA ISABEL L.; SANTA ISABEL, M. Natureza do humus nos latossolos distróficos da Bahia. R. Bras. Ci. Solo, v.2, n.1, p.59-63, 1978. 
WOOD, T. G. e SANDS, W. A. The role of termites in ecossystens. In: BRIAN, M. V., coord. Prodution ecology of ants and termites. London: Cambridge Un. Press, 1978. p. 245-292.

YOUNG, A. Slopes. London: Ed. Longman, 1972. 288p.

YOUNG, A. ; YOUNG, D. M. Slope development. London: Pub. Macmillan ducation Ltd. 1974. 35p. 
APÊNDICE 1

Descrição morfológica dos perfis 


\begin{tabular}{|c|c|c|c|c|c|}
\hline 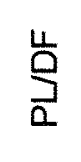 & 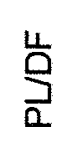 & & 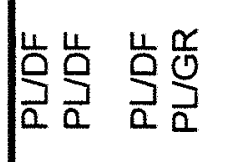 & 訔告 & 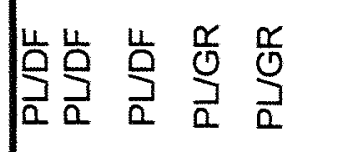 \\
\hline $\begin{array}{l}0 \\
\frac{1}{2} \\
\frac{0}{2}\end{array}$ & $\frac{0}{\frac{0}{2}}$ & $\frac{1}{\frac{1}{2}}$ & 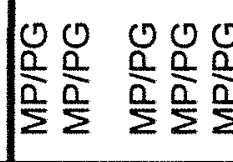 & 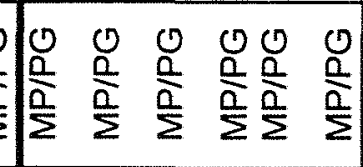 & 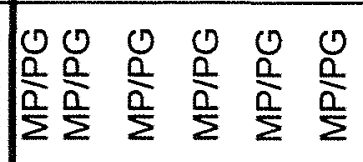 \\
\hline$\frac{q}{\underline{L}}$ & $\frac{\frac{\alpha}{u}}{\Sigma}$ & $\frac{\frac{x}{4}}{2}$ & 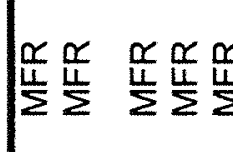 & 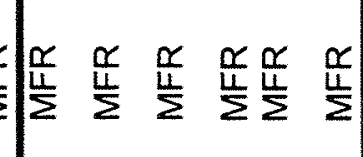 & 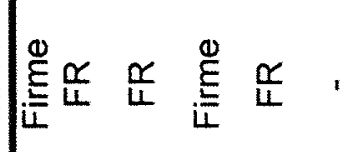 \\
\hline & & & & & 言 \\
\hline & 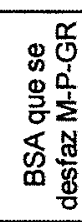 & & 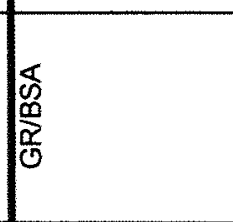 & 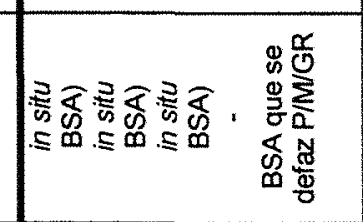 & 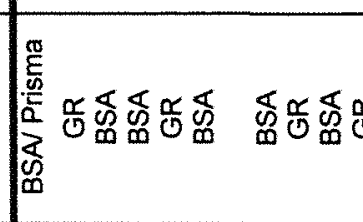 \\
\hline$\Sigma$ & 0 & & $\mid \begin{array}{l}\frac{2}{2} \\
\frac{1}{2} \\
\frac{1}{2}\end{array}$ & 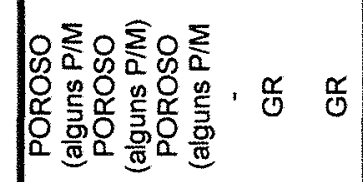 & 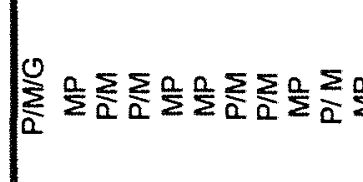 \\
\hline 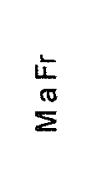 & & & 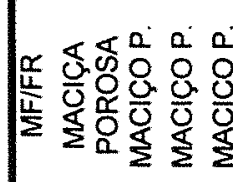 & 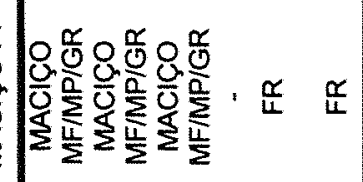 & $\sum \frac{\omega}{\Sigma} \Sigma \frac{u}{2}$ \\
\hline 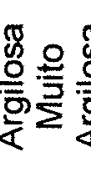 & $\frac{6}{5}$ & & 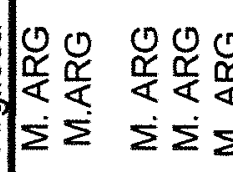 & 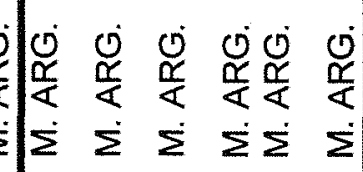 & 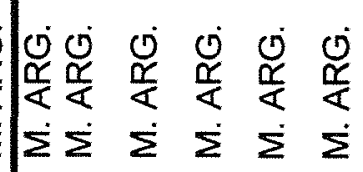 \\
\hline $\begin{array}{l}\frac{\infty}{10} \\
\frac{x}{2} \\
6\end{array}$ & $\begin{array}{l}\frac{\infty}{10} \\
\frac{x}{2} \\
i n\end{array}$ & & 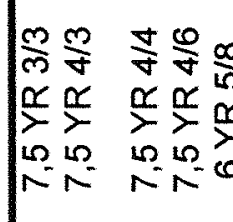 & 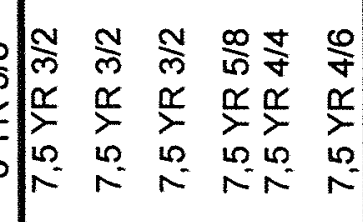 & 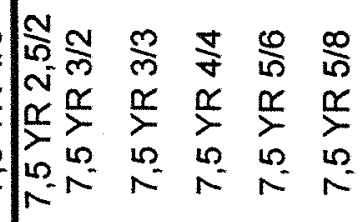 \\
\hline$\stackrel{\circ}{\grave{c}}$ & $\begin{array}{l}\stackrel{0}{0} \\
\vdots \\
\stackrel{0}{0}\end{array}$ & & 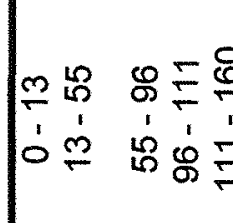 & 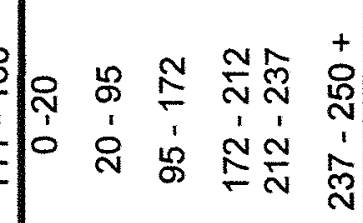 & 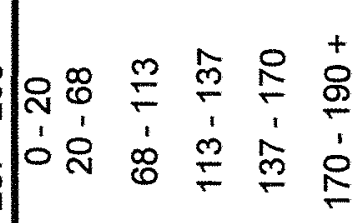 \\
\hline 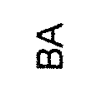 & 产 & & 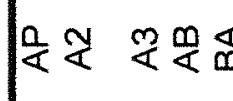 & 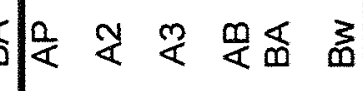 & 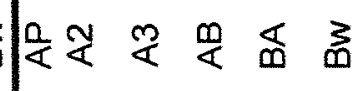 \\
\hline & & & $\bar{a}$ & a & $\dddot{2}$ \\
\hline
\end{tabular}




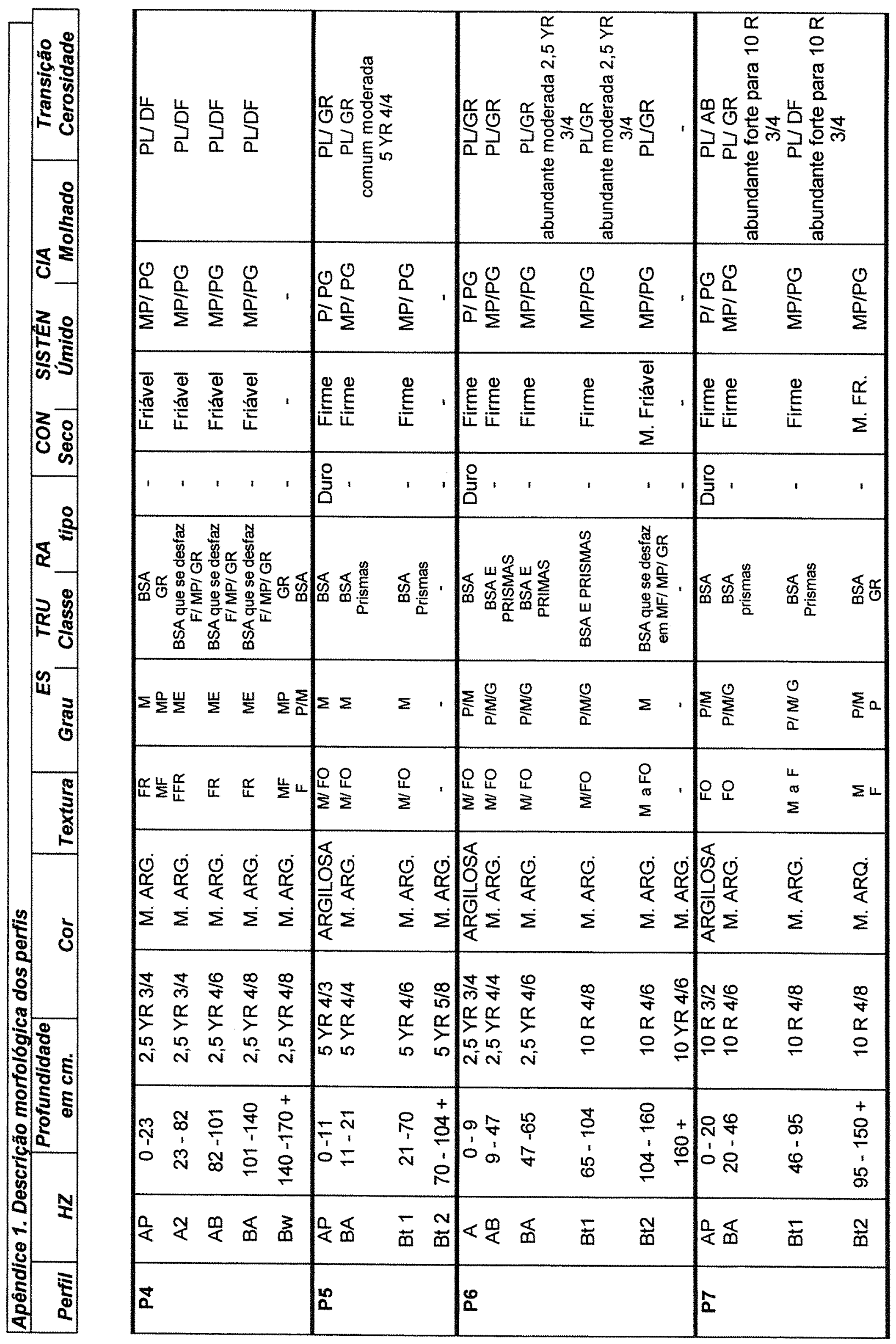




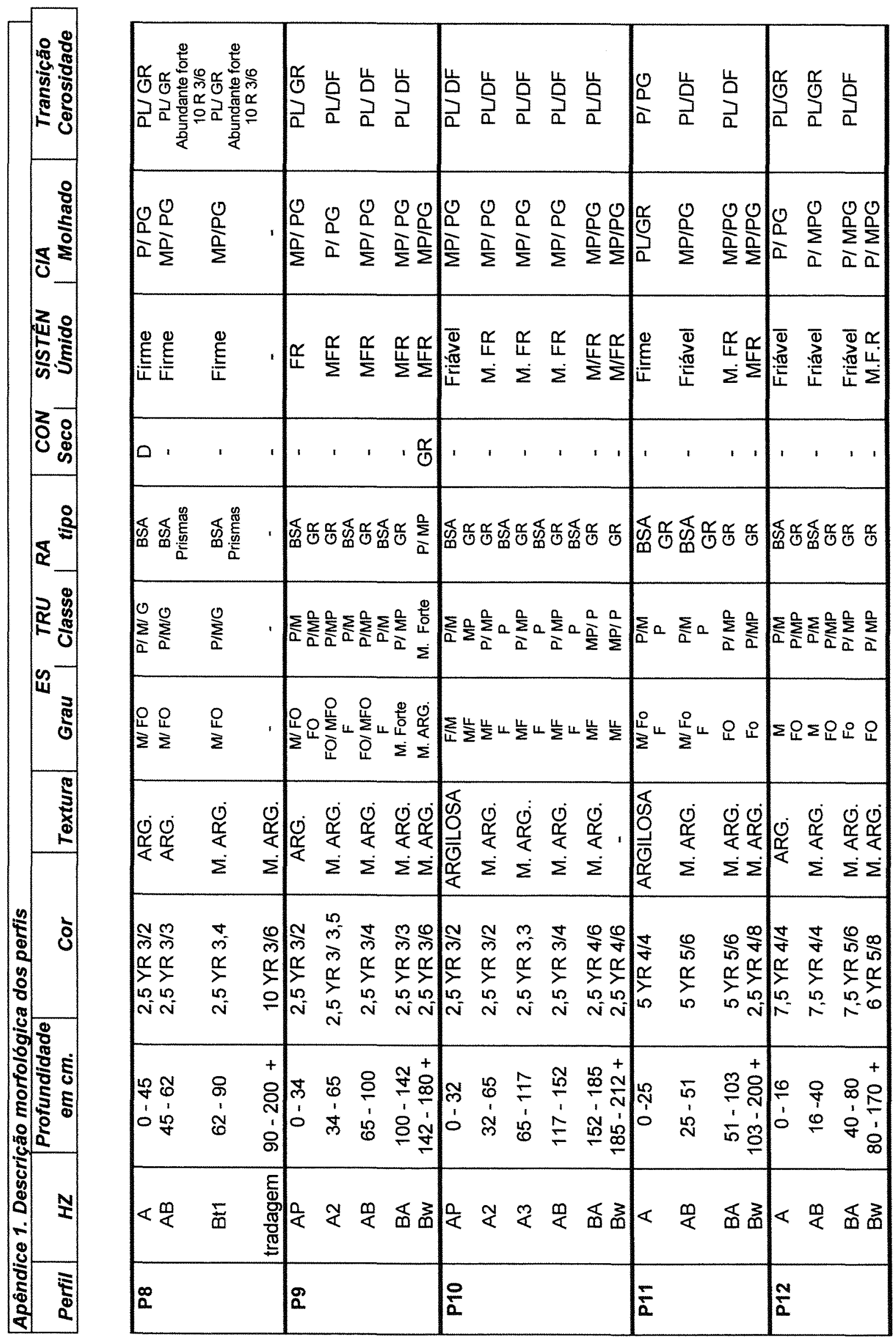




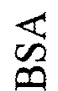

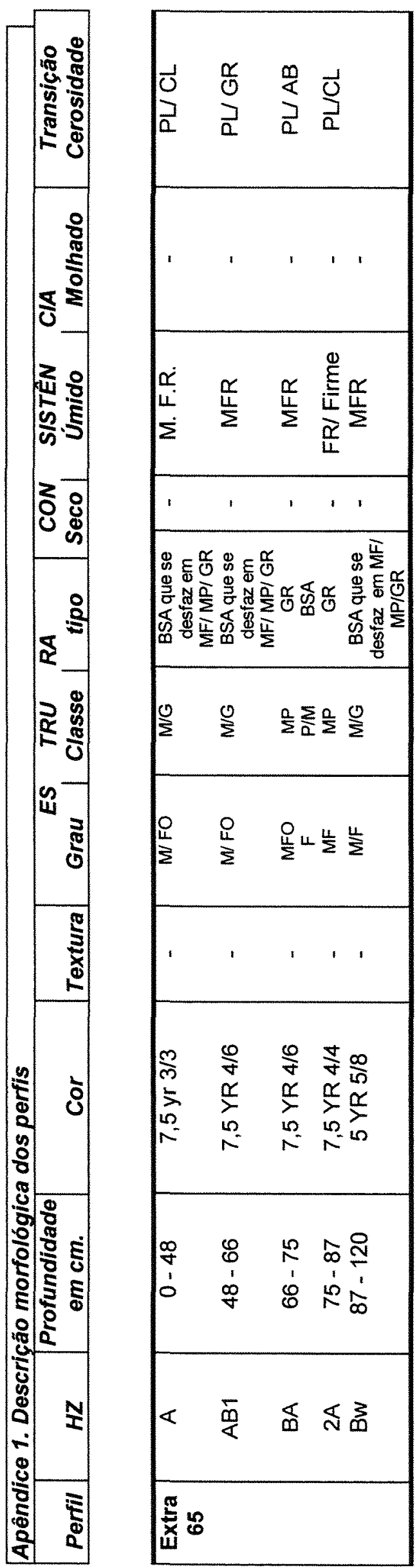

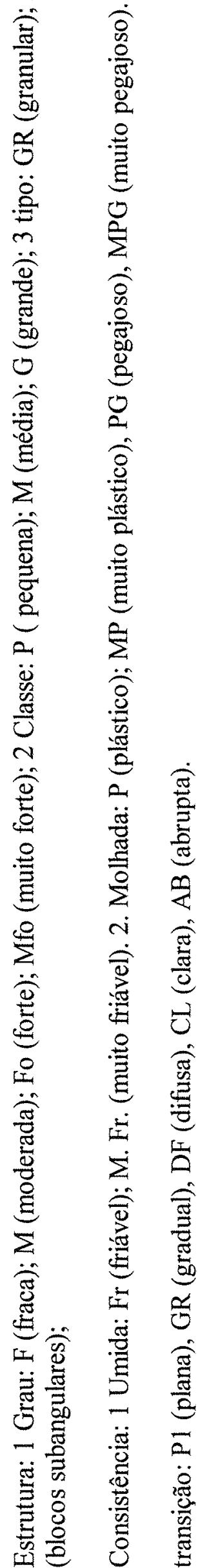




\section{APÊNDICE 2}

Análises granulométricas, de densidade do solo, de densidade de partículas e porosidade dos perfis estudados 


\begin{tabular}{|c|c|c|c|}
\hline 5 & 路芯 8 员昌 & $\operatorname{lom}_{0}$ & 他出专年㠻 \\
\hline Ea & 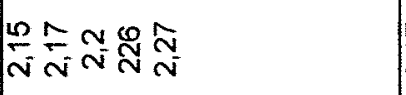 & $\operatorname{ni} \frac{N}{\pi}$ & 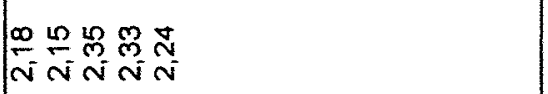 \\
\hline 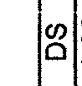 & 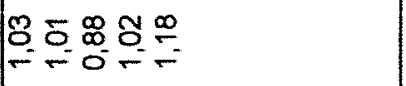 & $\begin{array}{l}\sqrt{1}: 0 \\
0: 0 \\
0: 0\end{array}$ & 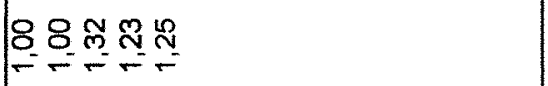 \\
\hline $\mid$ & $\mid \frac{1}{0}$ & 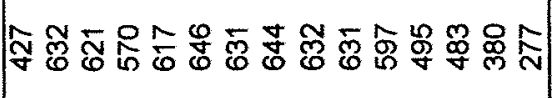 & 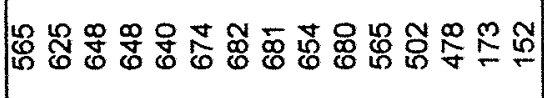 \\
\hline$\left|\begin{array}{|l} \\
\bar{\omega}\end{array}\right|$ & 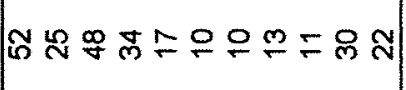 & ○® & 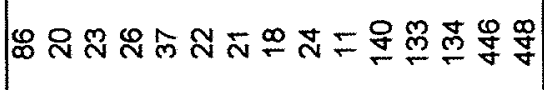 \\
\hline$k$ & 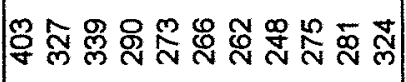 & 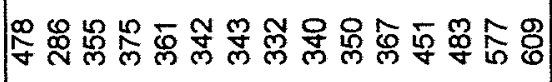 & 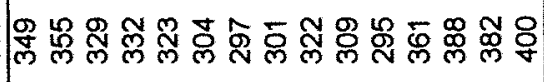 \\
\hline $\mid \frac{1}{<}$ & 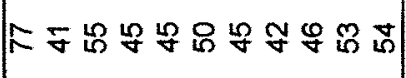 & 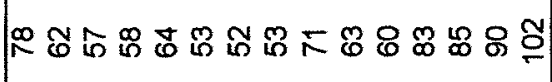 & 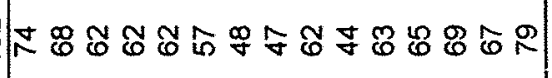 \\
\hline 品 & $\stackrel{2}{2}$ & 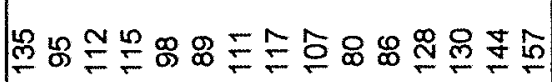 & 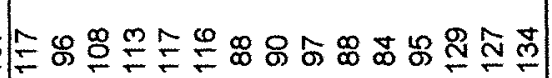 \\
\hline$\sum$ & 电 & 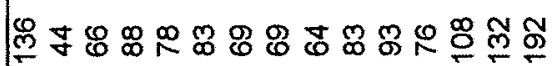 & 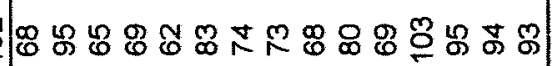 \\
\hline 0 & 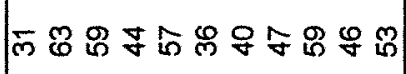 & 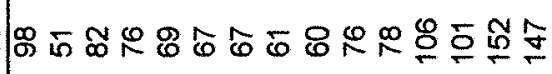 & : ஜ \\
\hline $\mid \frac{0}{2}$ & 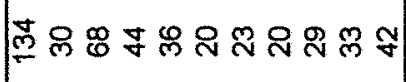 & 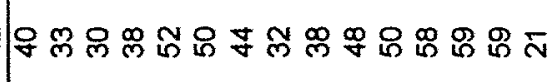 & W \\
\hline 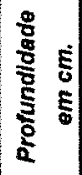 & 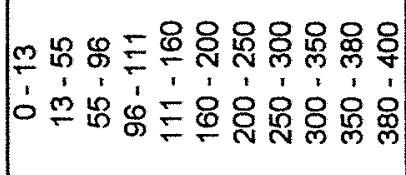 & 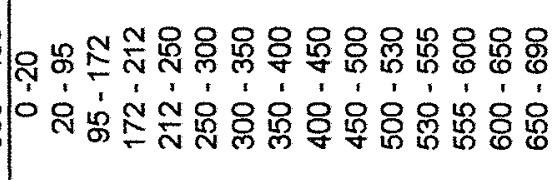 & 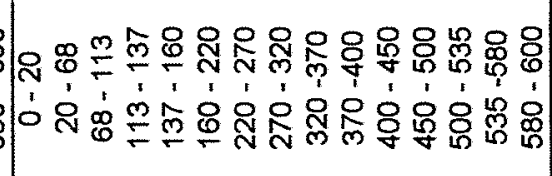 \\
\hline $\mathbf{N}$ & 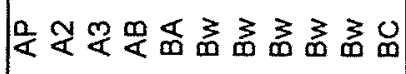 & 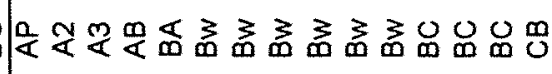 & 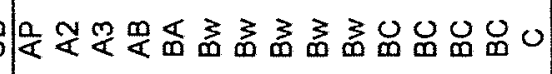 \\
\hline \$ & $\overline{2}$ & $\tilde{\alpha}$ & 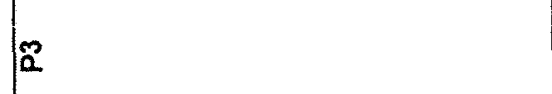 \\
\hline
\end{tabular}




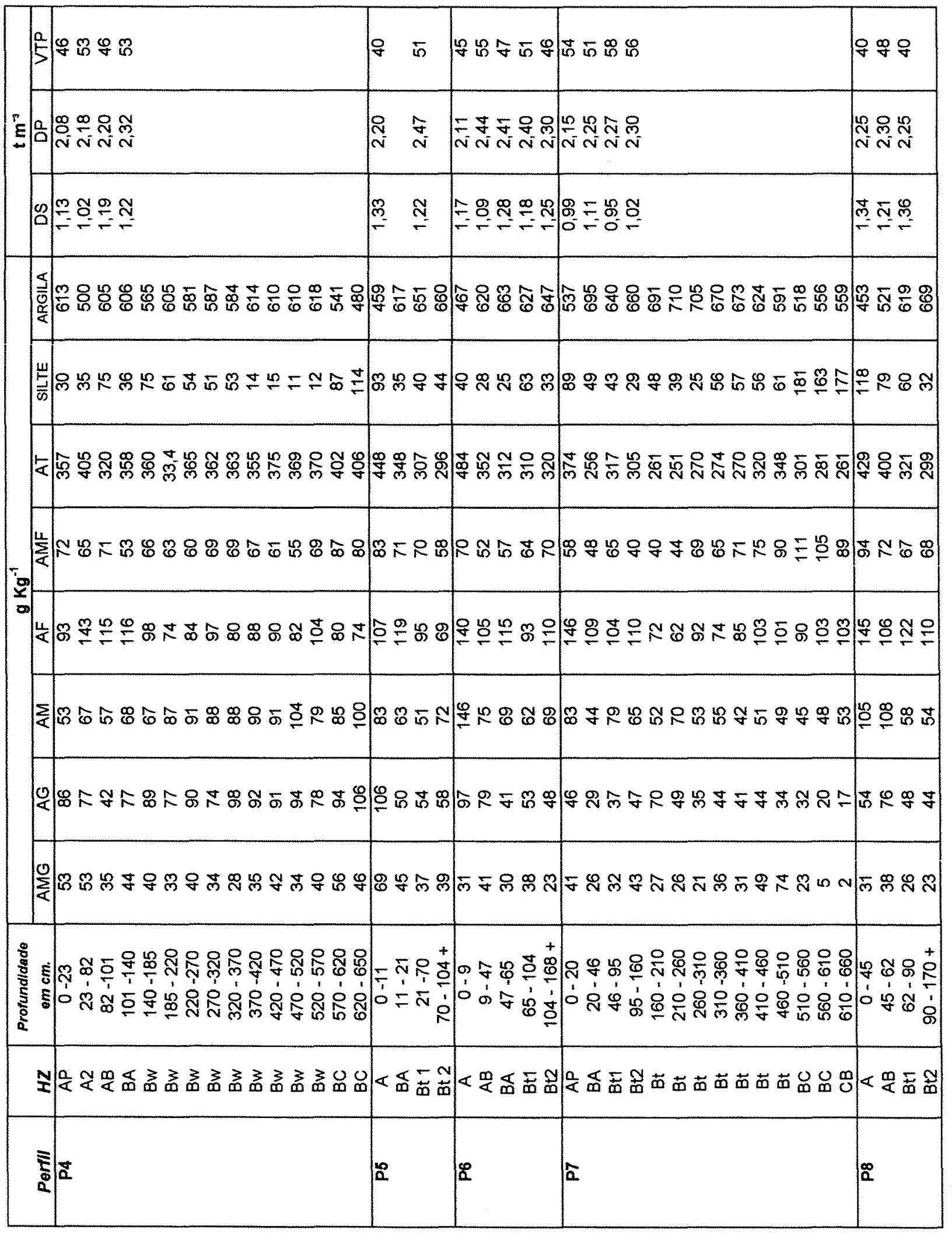




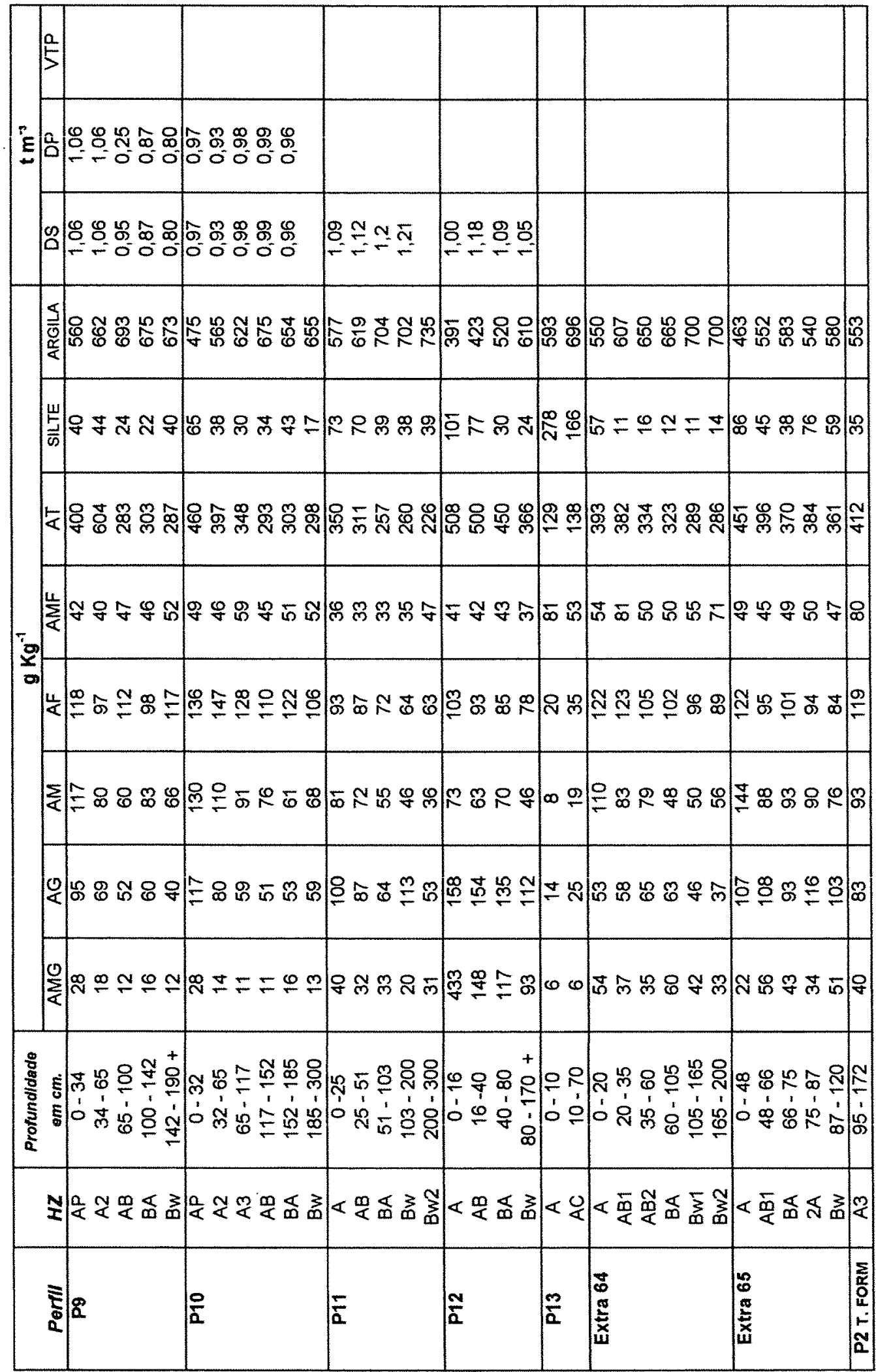




\section{APÊNDICE 3}

Análise químicas e cor dos perfis estudados 


\begin{tabular}{|c|c|c|c|}
\hline 5 & 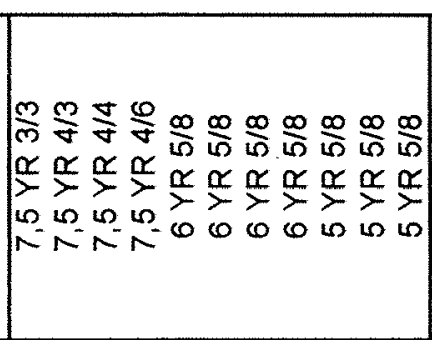 & 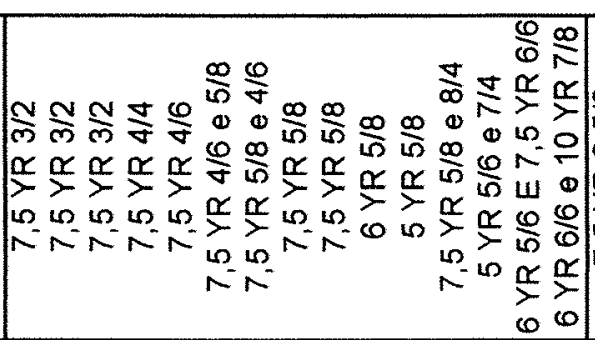 & 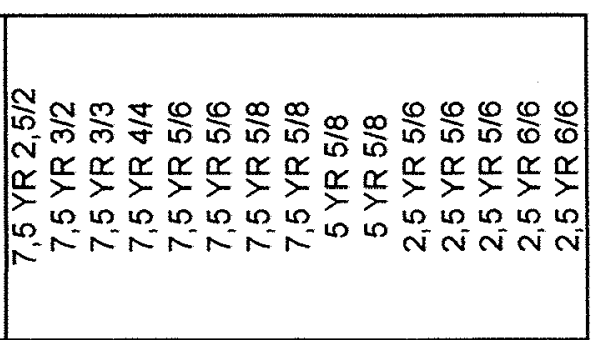 \\
\hline & 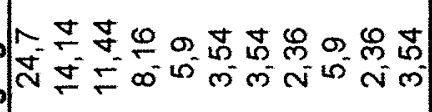 & 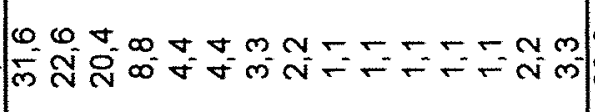 & 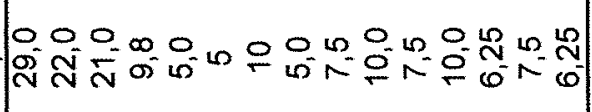 \\
\hline$\varepsilon$ & 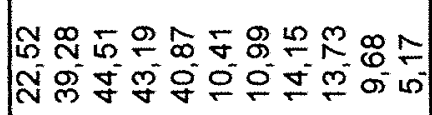 & 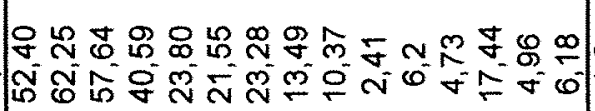 & 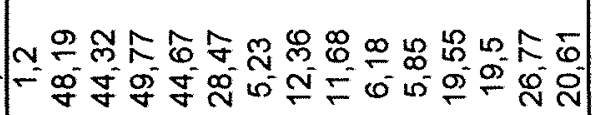 \\
\hline$>$ & 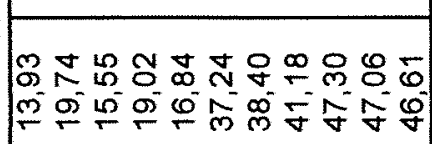 & 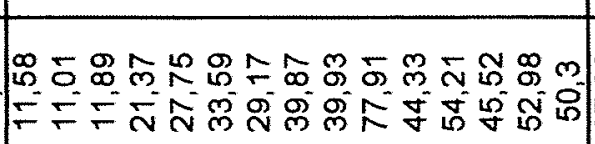 & 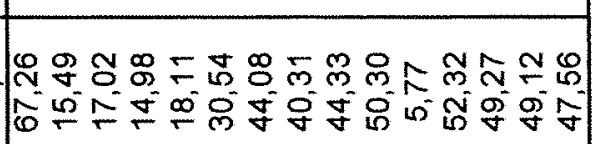 \\
\hline ֻٕ & 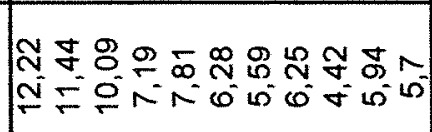 & 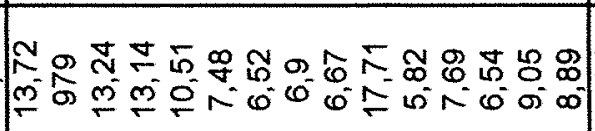 & 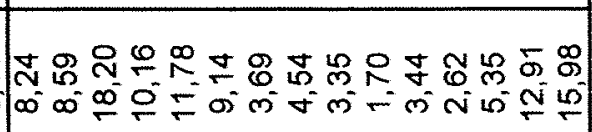 \\
\hline 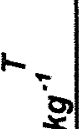 & 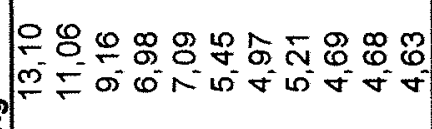 & 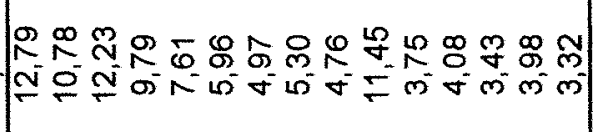 & 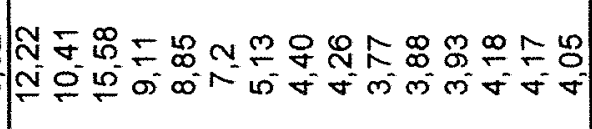 \\
\hline œ & 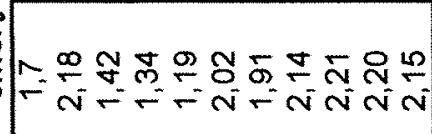 & $\mid$\begin{tabular}{l}
$\infty$ \\
$q$ \\
\hdashline
\end{tabular} & 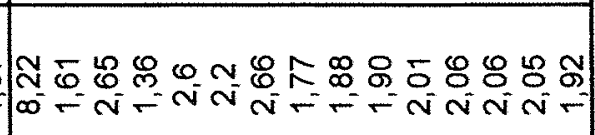 \\
\hline $\begin{array}{ll}\vec{x} \\
\\
\end{array}$ & 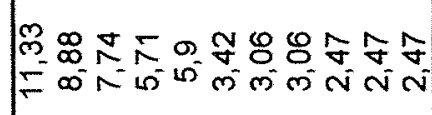 & 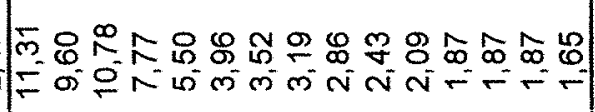 & 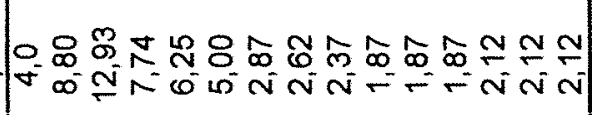 \\
\hline$a \frac{7}{9}$ & 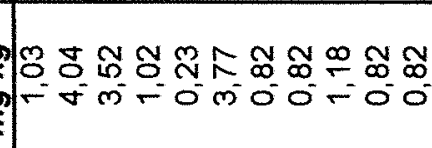 & 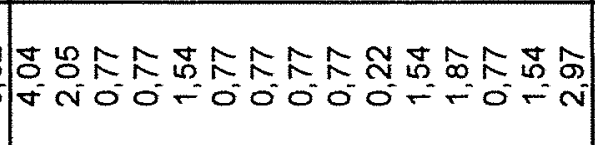 & 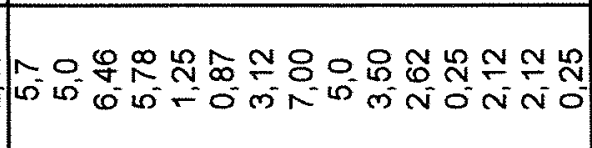 \\
\hline$\frac{1}{2} \underset{1}{0}$ & 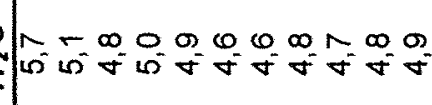 & 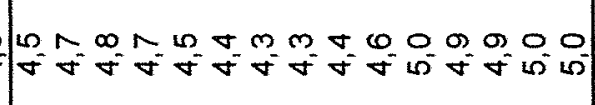 & 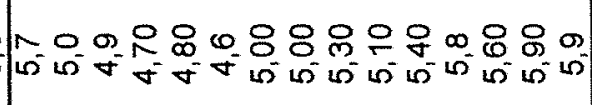 \\
\hline 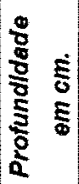 & 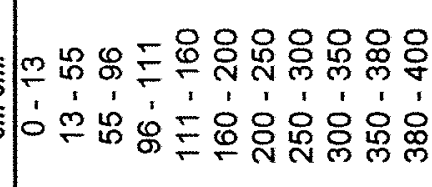 & 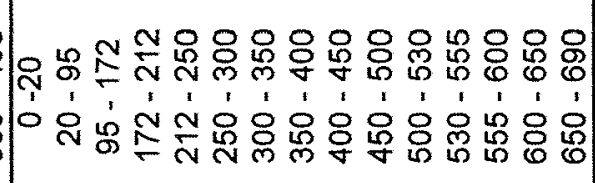 & 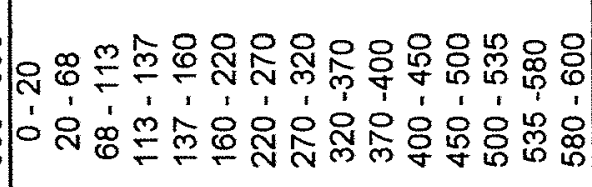 \\
\hline $\mathbf{x}$ & 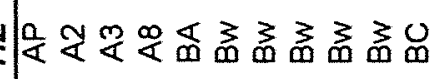 & 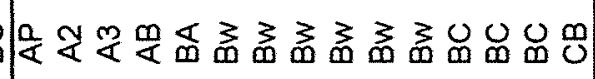 & 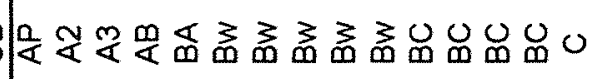 \\
\hline 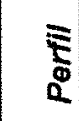 & 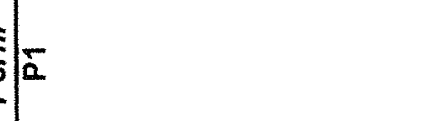 & $\mathbf{a}$ & $\mathbb{a}$ \\
\hline
\end{tabular}




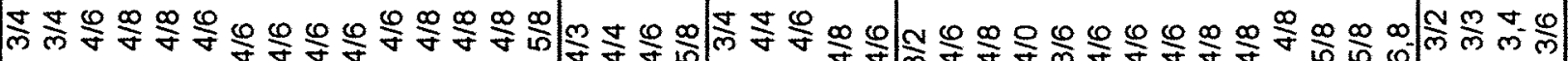

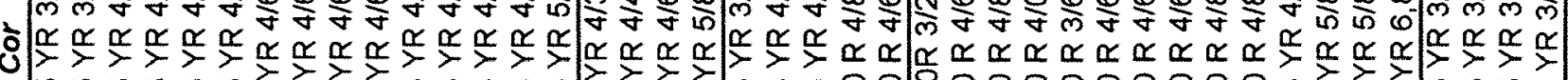
w

\begin{tabular}{ll|l|l|} 
& & & \\
\hline
\end{tabular}

o ह :

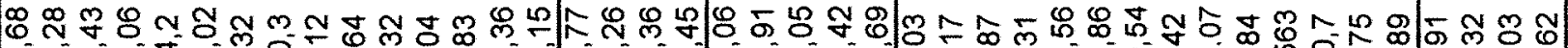
E क ल

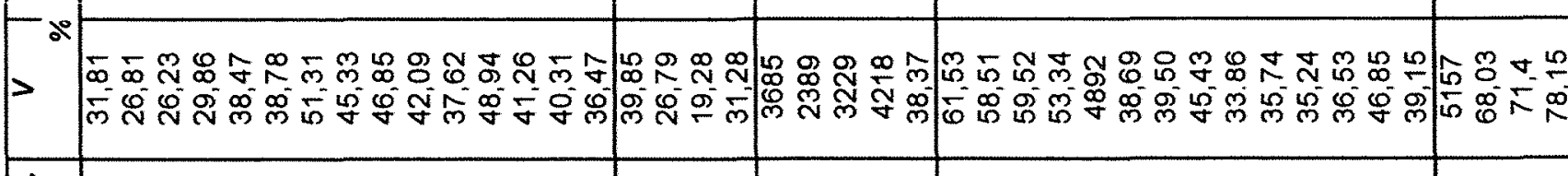

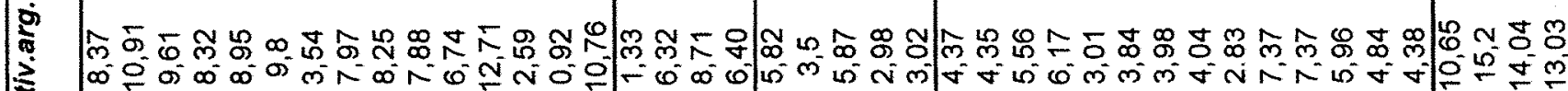

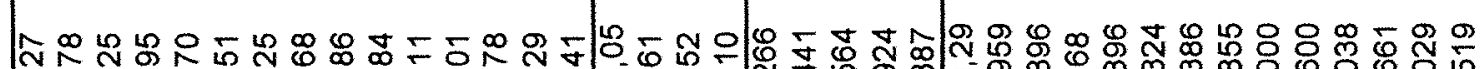
(잉

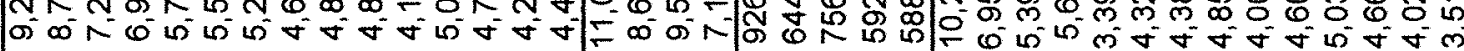

ㅇํㅇ

\#息

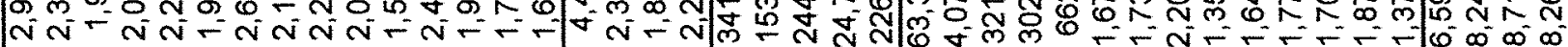

NNm ल 0

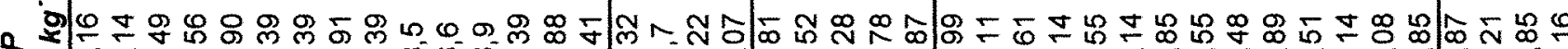
a Dल

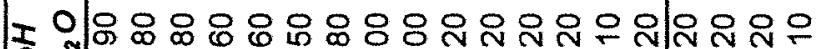

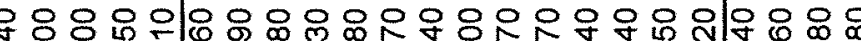

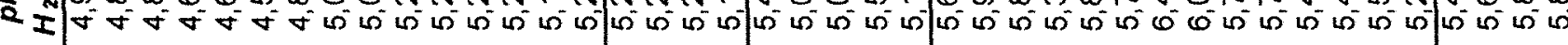

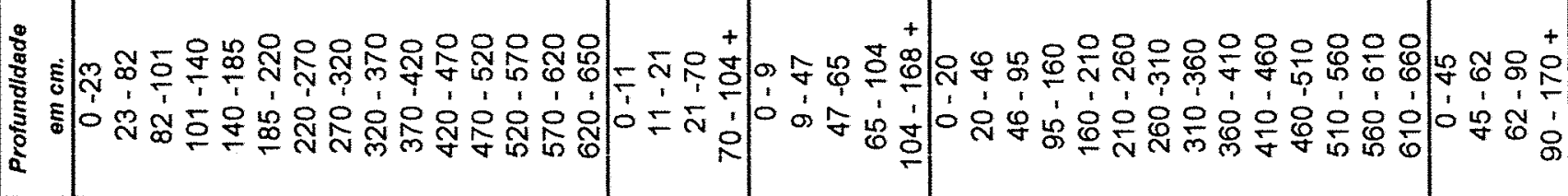

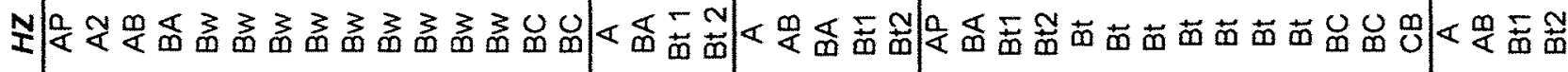
홍

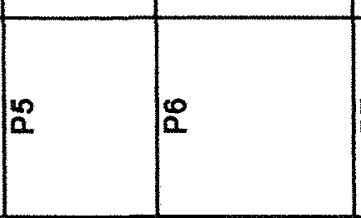




\begin{tabular}{|c|c|c|c|c|c|c|c|c|}
\hline$\$$ & 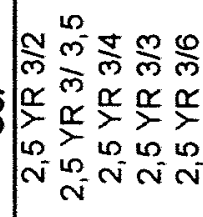 & 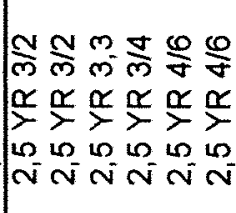 & 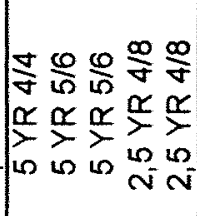 & 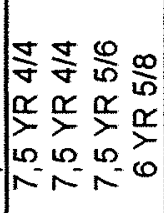 & 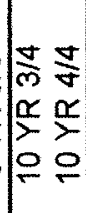 & 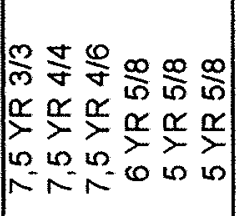 & 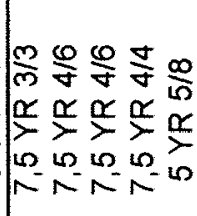 & 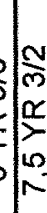 \\
\hline & 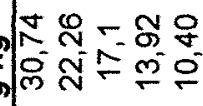 & 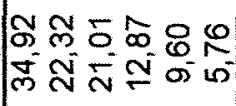 & 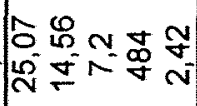 & 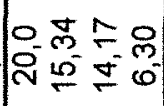 & $\mid \begin{array}{ll}0 & 0 \\
0 & 0 \\
2 & -\end{array}$ & 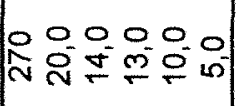 & 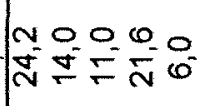 & 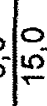 \\
\hline$E$ & 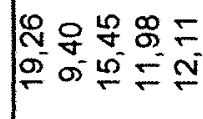 & 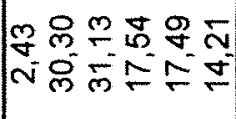 & 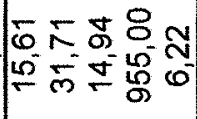 & 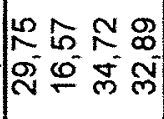 & $\mid$\begin{tabular}{ll}
- & $\infty$ \\
$\infty$ & 0 \\
5 & -1 \\
\hdashline & -1
\end{tabular} & 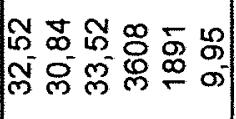 & 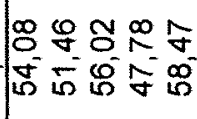 & 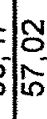 \\
\hline$>$ & 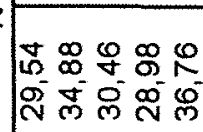 & 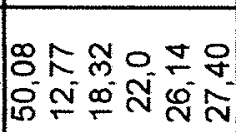 & 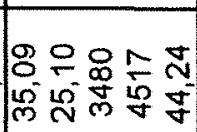 & 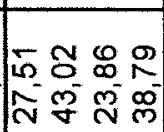 & $\left|\begin{array}{ll}0 & m \\
0 & 0 \\
-1 & 0 \\
m & 0\end{array}\right|$ & 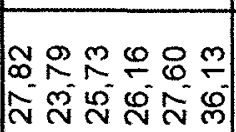 & 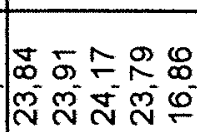 & $m$ \\
\hline 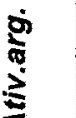 & 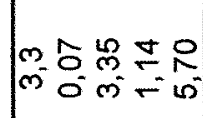 & 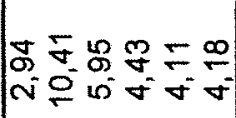 & 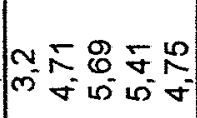 & 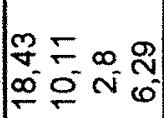 & $\mid \begin{array}{cc}F & 0 \\
0 & 0 \\
0 & 0 \\
0 & 0\end{array}$ & 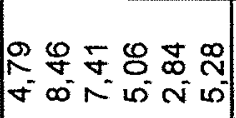 & 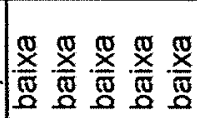 & $\mid \frac{\pi}{\tilde{a}}$ \\
\hline & 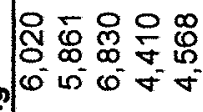 & 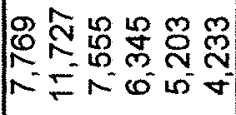 & 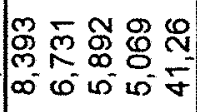 & 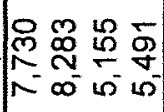 & $\mid$\begin{tabular}{ll}
0 & 0 \\
& 0 \\
- & 0 \\
\hdashline & $\infty$
\end{tabular} & 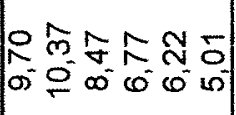 & 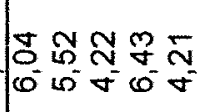 & $=$ \\
\hline $\operatorname{si} \frac{\bar{g}}{0}$ & 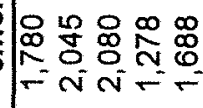 & $\begin{array}{l}\mathscr{g} \\
\infty \\
\infty \\
\infty \\
m\end{array}$ & 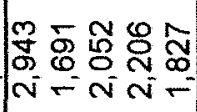 & 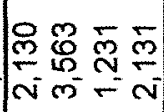 & $\mid$\begin{tabular}{ll}
0 & 0 \\
\hdashline & 0 \\
\hdashline & 0 \\
$m$
\end{tabular} & 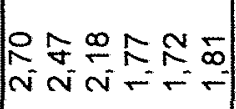 & $\mid$\begin{tabular}{l}
$\forall$ \\
$\forall$ \\
\hdashline
\end{tabular} & 5 \\
\hline 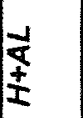 & 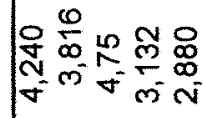 & 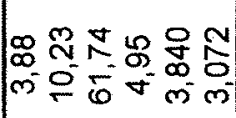 & 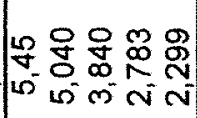 & 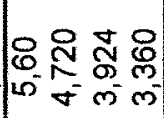 & 88 & $\left|\begin{array}{cccccc}8 & 8 & 8 & 8 & 0 & 9 \\
N & 0 & 0 & 0 & 0 & 0 \\
N\end{array}\right|$ & 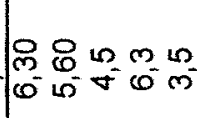 & 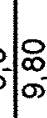 \\
\hline $\begin{array}{ll}a & 0 \\
0 & 0\end{array}$ & 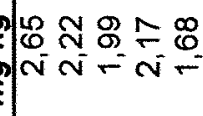 & 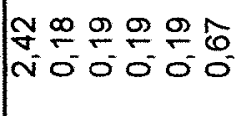 & 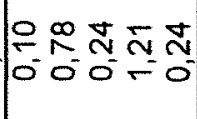 & 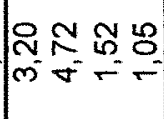 & $\mid \begin{array}{l}8 \\
8 \\
0\end{array}$ & 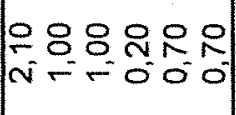 & 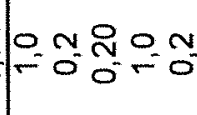 & $P^{0}$ \\
\hline$\frac{1}{2} \underset{n}{1}$ & $\mid \begin{array}{ccccc}0 & 8 & 0 & 0 & 0 \\
0 & 0 & 8 & 10 & 0 \\
10 & 10 & 10 & 10 & 10\end{array}$ & 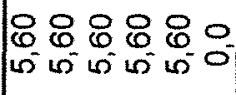 & 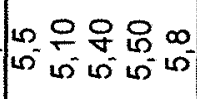 & 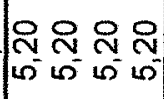 & 50 & 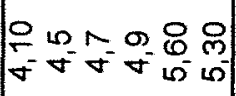 & 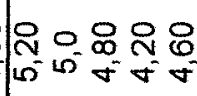 & $=0$ \\
\hline 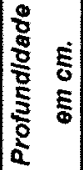 & 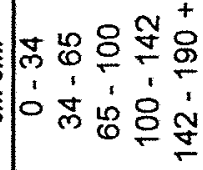 & 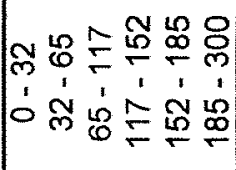 & 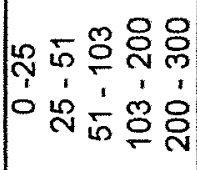 & 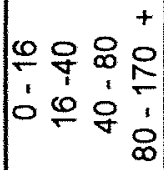 & $\mid$\begin{tabular}{ll}
0 & 0 \\
\hdashline & 1 \\
0 & 0
\end{tabular} & 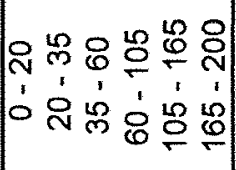 & 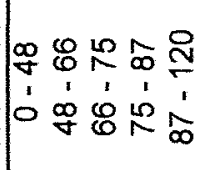 & $\frac{N}{\frac{N}{1}}$ \\
\hline$\frac{N}{x}$ & 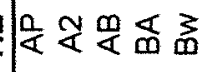 & 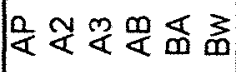 & 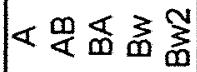 & 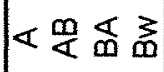 & $\varangle \%$ & 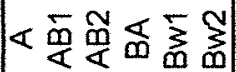 & 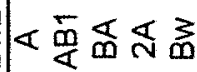 & 3 \\
\hline$\stackrel{5}{\Phi}$ & I & 울 & $\bar{a}$ & $\mid \stackrel{N}{a}$ & $\frac{m}{a}$ & $\mid \begin{array}{l}8 \\
0 \\
w \\
\frac{5}{x} \\
w\end{array}$ & 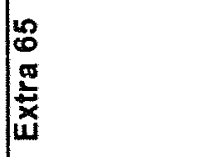 & 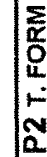 \\
\hline
\end{tabular}




\section{APÊNDICE 4}

Análises de fluorecência de raios $\mathrm{X}(\mathrm{Fe}, \mathrm{Ti}, \mathrm{Zr}$ ), relação $\mathrm{Ti} / \mathrm{Zr}$ e mineralogia das

frações silte e argila 


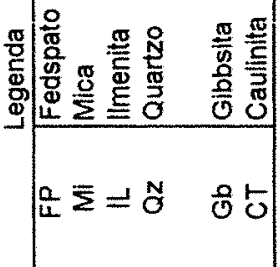

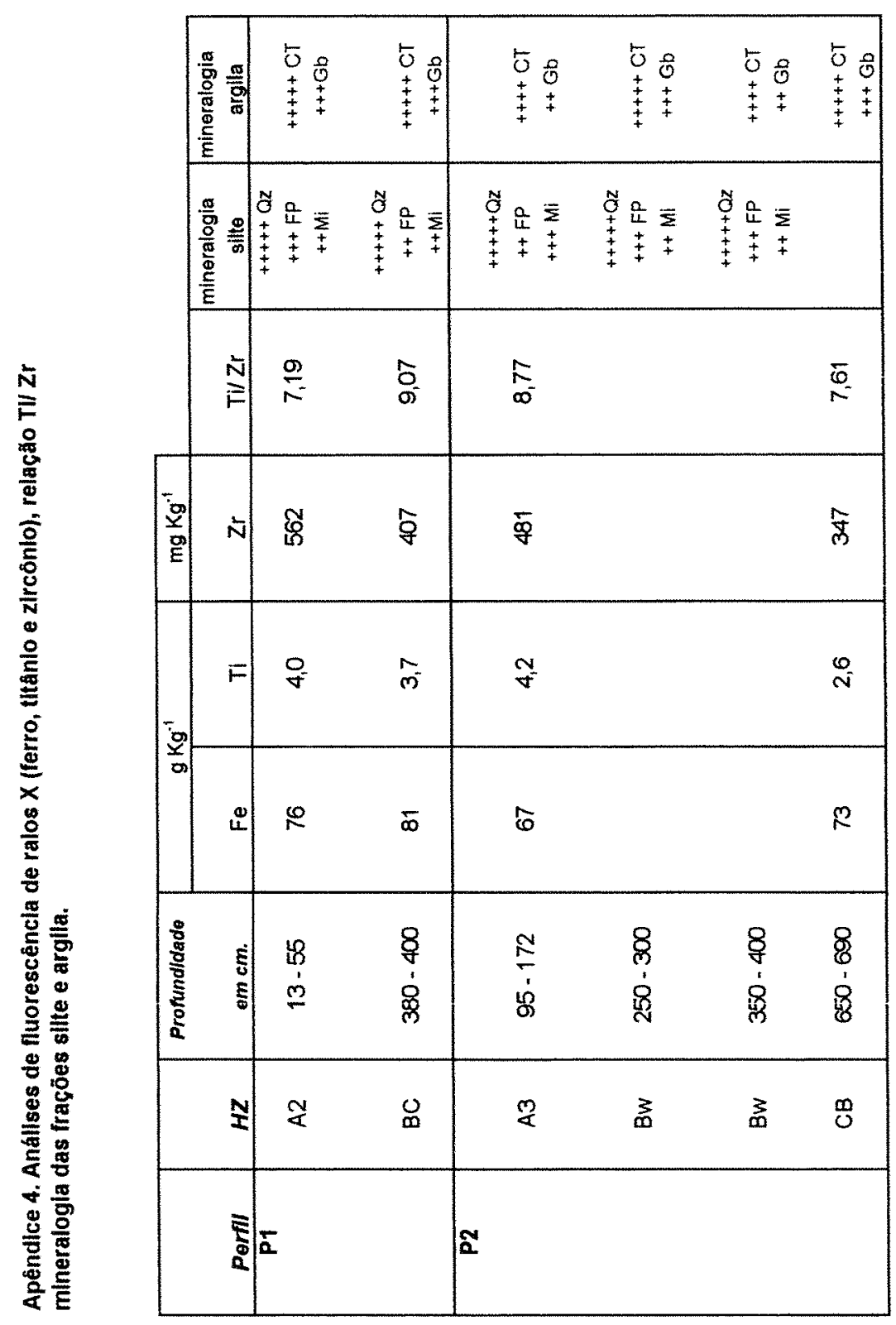




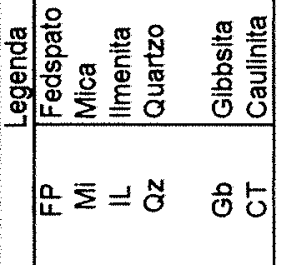

\begin{tabular}{|c|c|c|c|c|c|c|c|c|}
\hline 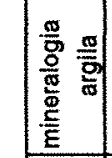 & $\begin{array}{ll}5 & \\
0 & 0 \\
+ & 0 \\
+ & + \\
+ & + \\
\end{array}$ & $\begin{array}{l}5 \\
\vdots \\
+ \\
+ \\
+ \\
+\end{array}$ & $\begin{array}{l}5 \\
\vdots \\
+ \\
+ \\
+ \\
+\end{array}$ & $\begin{array}{l}5 \\
\vdots \\
+ \\
+ \\
+ \\
+\end{array}$ & $\begin{array}{l}5 \\
\vdots \\
+ \\
+ \\
+ \\
+\end{array}$ & $\begin{array}{l}5 \\
\vdots \\
+ \\
+ \\
+\end{array}$ & $\begin{array}{l}5 \\
\vdots \\
+ \\
+ \\
+\end{array}$ & $\begin{array}{l}5 \\
\vdots \\
+ \\
+ \\
+ \\
+\end{array}$ \\
\hline 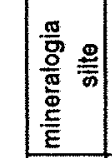 & 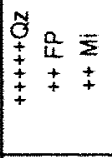 & 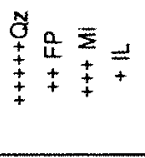 & 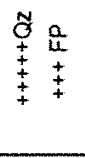 & 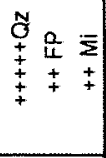 & 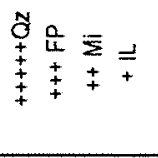 & 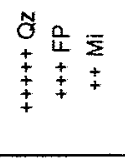 & 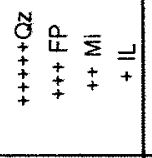 & 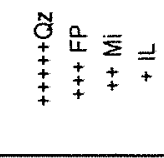 \\
\hline$\stackrel{N}{\stackrel{N}{F}}$ & $\underset{\infty}{8}$ & & $\stackrel{8}{\stackrel{8}{N}}$ & $\stackrel{8}{\underline{m}}$ & & $\hat{m}$ & $\underset{\mathbb{N}}{\stackrel{N}{2}}$ & \\
\hline 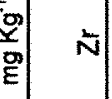 & : & & $\frac{\mathscr{P}}{\mathrm{V}}$ & $\widehat{8}$ & & $\frac{\infty}{i}$ & 8 & \\
\hline$F$ & $\overline{60}$ & & 8 & $\stackrel{\sim}{6}$ & & $\bar{N}$ & $\bar{\sigma}$ & \\
\hline$\ddot{\infty}$ & 8 & & 8 & $\overline{5}$ & & $\overline{0}$ & 83 & \\
\hline : & $\begin{array}{l}8 \stackrel{9}{7} \\
\dot{8} \\
\dot{8}\end{array}$ & $\begin{array}{l}\stackrel{N}{N} \\
\stackrel{N}{~}\end{array}$ & $\begin{array}{l}8 \\
8 \\
8 \\
8\end{array}$ & $\begin{array}{l}8 \\
\dot{8} \\
\dot{8}\end{array}$ & 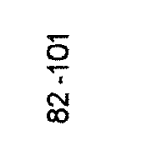 & $\begin{array}{l}\text { \& } \\
\stackrel{2}{8} \\
\text { e }\end{array}$ & $\begin{array}{l}8 \\
8 \\
\dot{8} \\
80\end{array}$ & $\frac{p}{i}$ \\
\hline $\mathbf{N}$ & 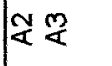 & 高 & O & 0 & $\stackrel{\infty}{<}$ & 盖 & O & $\overline{\mathbf{0}}$ \\
\hline \$్ & $\ddot{2}$ & & & & \pm & & & 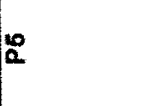 \\
\hline
\end{tabular}




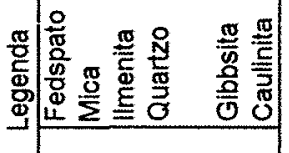

迹 $\bar{\Sigma}=\mathbb{N}$ ㅇํㄴ

\begin{tabular}{|c|c|c|c|c|c|c|c|c|c|}
\hline 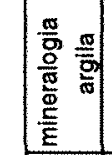 & $\begin{array}{l}5 \\
5 \\
+0 \\
+ \\
+ \\
+\end{array}$ & $\begin{array}{l}5 \\
0 \\
+0 \\
+0 \\
+ \\
+\end{array}$ & $\begin{array}{l}50 \\
0 \\
+ \\
+ \\
+ \\
+\end{array}$ & $\begin{array}{l}5 \\
\vdots \\
+ \\
+ \\
+ \\
+\end{array}$ & $\mid \begin{array}{ll}0 & 0 \\
0 & 0 \\
+ & +\end{array}$ & $\begin{array}{ll}5 & 0 \\
\vdots & 0 \\
+ & + \\
+ & +\end{array}$ & $\begin{array}{l}5 \\
0 \\
+ \\
+ \\
+\end{array}$ & $\begin{array}{cc}5 & 0 \\
+ & 0 \\
+ & \ddagger\end{array}$ & $\mid \begin{array}{ll}5 & 0 \\
\vdots & 0 \\
\vdots & +\end{array}$ \\
\hline 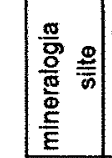 & 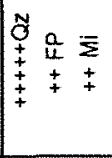 & 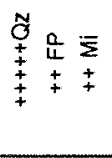 & 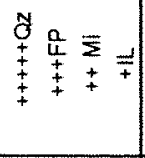 & 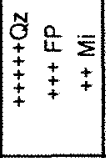 & 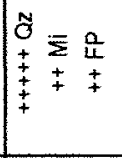 & 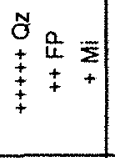 & 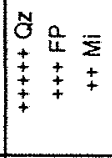 & 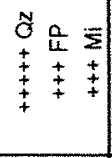 & 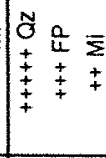 \\
\hline$\stackrel{N}{\vec{F}}$ & $\stackrel{\mathscr{R}}{\stackrel{M}{2}}$ & 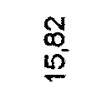 & $\begin{array}{l}n \\
0 \\
0\end{array}$ & & $\underset{\infty}{\infty}$ & 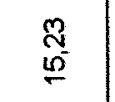 & $\begin{array}{l}q \\
\text { \& }\end{array}$ & $\frac{\varphi}{\sigma}$ & \\
\hline 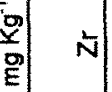 & $\overline{8}$ & 怘 & $\hat{\theta}$ & & To & 粉 & $\$$ & 疋 & $\mathbb{8}$ \\
\hline$F$ & $\stackrel{10}{\sigma}$ & $\frac{\nabla}{\nabla}$ & $\stackrel{m}{\sigma}$ & & $\hat{\circ}$ & $=$ & 只 & \pm & 응 \\
\hline 农 & œ & $\bar{\infty}$ & 8 & & $\stackrel{\circ}{2}$ & $\bar{I}$ & 응 & $\underline{8}$ & 这 \\
\hline 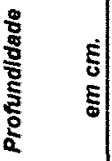 & $\frac{8}{\dot{8}}$ & 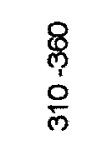 & $\begin{array}{l}8 \\
8 \\
\dot{0} \\
\stackrel{0}{0}\end{array}$ & $\frac{+}{\frac{1}{2}}$ & m & 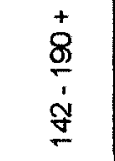 & $\begin{array}{l}8 \\
\dot{m} \\
\dot{m}\end{array}$ & 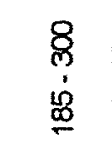 & סֵ \\
\hline $\mathbf{N}$ & $\underset{\mathbb{0}}{\mathbb{N}}$ & 苗 & $\mathscr{O}$ & 㩊 & $\frac{a}{\alpha}$ & 亯 & $\underset{\&}{q}$ & 亳 & $<$ \\
\hline$\$$ & 2 & & & 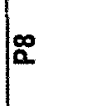 & 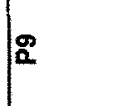 & & $\frac{0}{a}$ & & $\frac{F}{\alpha}$ \\
\hline
\end{tabular}




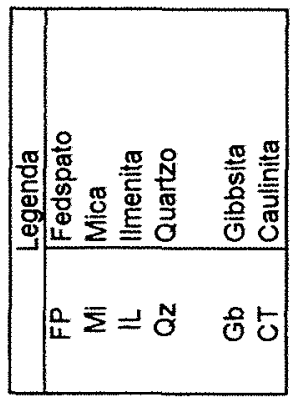

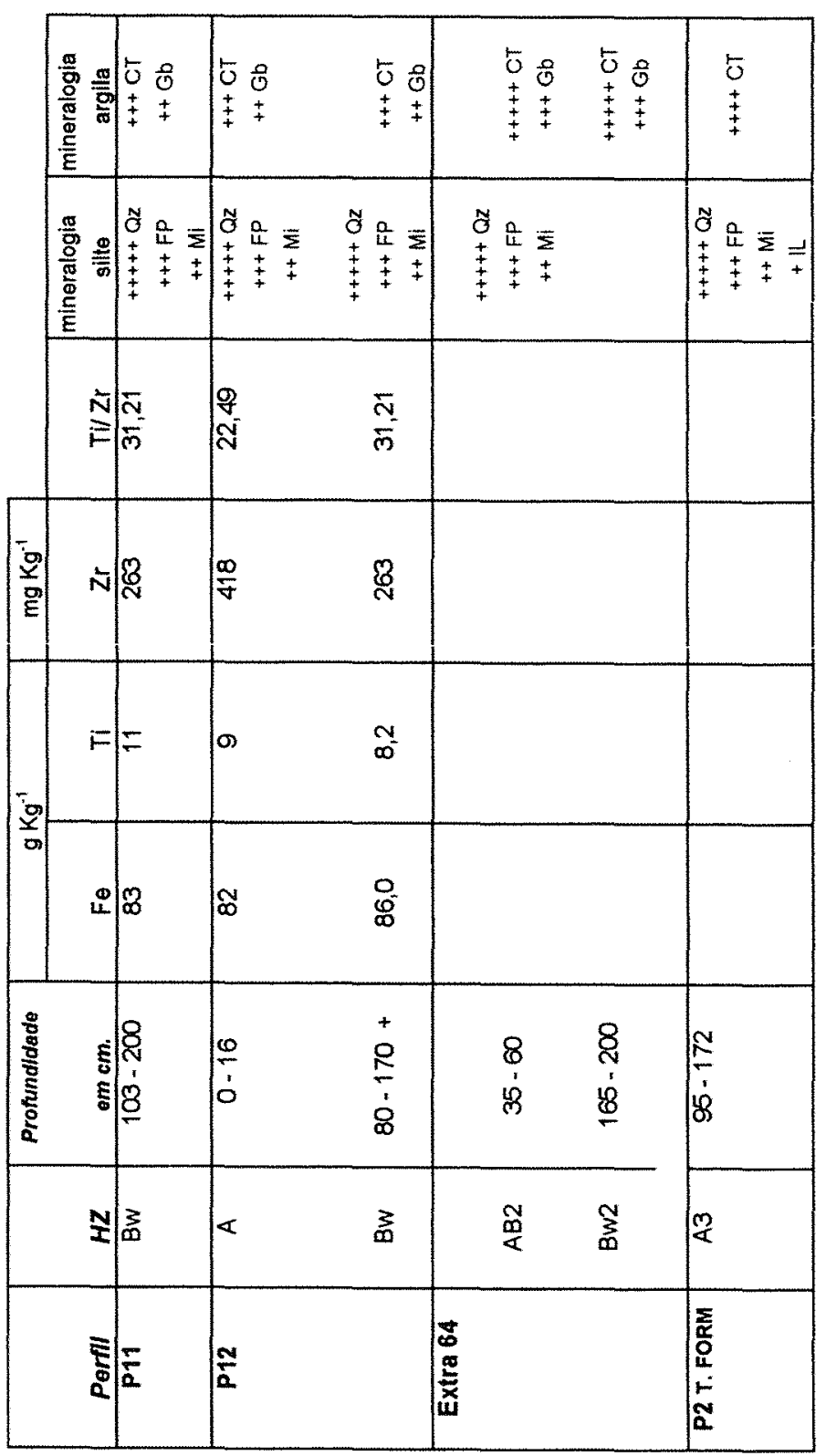




\section{APÊNDICE 5}

Cálculos estatísticos da distribuição granulométrica das areias 
Arquivo de entrada SMP1.DAT

Arquivo de saida SMP1. OUT

19-01-1998 09:14:31

PI AP $0-13$

$\begin{array}{rrrrr}\text { intervalo phi } & \text { valor abs } & \% \text { rel } & \% \text { cum } \\ -1.00 \text { a } & 0.00 & 13.40 & 33 & 33 \\ 0.00 \text { a } & 1.00 & 3.10 & 8 & 41 \\ 1.00 \text { a } & 2.00 & 4.60 & 11 & 52 \\ 2.00 \text { a } & 3.00 & 11.50 & 29 & 81 \\ 3.00 \text { a } & 4.30 & 7.70 & 19 & 100\end{array}$

Interpretacao do grafico (segundo Folk e Ward, 1957) : media grafica 1.543

desvio padrao 1.505 pobremente selecionado

assimetria $\quad-0.190$ assimetria negativa (grosseiros)

curtose $\quad+0.616$ muito platicurtico

P1 A2 13-55

$\begin{array}{rrrrr}\text { intervalo phi } & \text { valor abs } & \text { orel } & \% \text { cum } \\ -1.00 \text { a } & 0.00 & 3.00 & 9 & 9 \\ 0.00 \text { a } & 1.00 & 6.30 & 19 & 28 \\ 1.00 \text { a } & 2.00 & 8.00 & 24 & 53 \\ 2.00 \text { a } & 3.00 & 11.30 & 35 & 87 \\ 3.00 \text { a } & 4.30 & 4.10 & 13 & 100\end{array}$

Interpretacao do grafico (segundo Folk e Ward, 1957) : media grafica 1.739

desvio padrao 1.191 pobremente selecionado

assimetria -0.158 assimetria negativa (grosseiros)

curtose +0.939 mesocurtico

\section{P1 A3 55-96}

intervalo phi

-1.00 a 0.00

valor abs \%rel \%cum

0.00 a 1.00

6.80

$20 \quad 20$

1.00 a 2.00

5.90

$17 \quad 37$

2.00 a 3.00

5.00

15

10.70

32

52

3.00 a 4.30

5.50

16100

Interpretacao do grafico (segundo Folk e Ward, 1957) : media grafica 1.588

desvio padrao 1.409 pobremente selecionado

assimetria $\quad-0.213$ assimetria negativa (grosseiros)

curtose

+0.734 platicurtico 


$\begin{array}{rrrrr}\text { intervalo phi } & \text { valor abs } & \% \text { rel } & \% \text { cum } \\ -1.00 \text { a } & 0.00 & 4.40 & 15 & 15 \\ 0.00 \text { a } & 1.00 & 4.40 & 15 & 30 \\ 1.00 \text { a } & 2.00 & 6.20 & 21 & 52 \\ 2.00 \text { a } & 3.00 & 9.50 & 33 & 84 \\ 3.00 \text { a } & 4.30 & 4.50 & 16 & 100\end{array}$

Interpretacao do grafico (segundo Folk e Ward, 1957) : media grafica 1.665 desvio padrao 1.352 assimetria $\quad-0.208$ pobremente selecionado curtose $+0.862$ assimetria negativa (grosseiros)
platicurtico

P1 BA 111-160

intervalo phi -1.00 a 0.00 0.00 a 1.00 valor abs \%rel \%cum $3.60 \quad 13 \quad 13$

1.00 a 2.00

5.70 $21 \quad 34$

2.00 a 3.00 5.70 $21 \quad 55$

3.00 a 4.30

7.80 $29 \quad 84$

$4.50 \quad 16 \quad 100$

Interpretacao do grafico (segundo Folk e Ward, 1957) : media grafica 1.650 desvio padrao 1.320 assimetria $\quad-0.102$ curtose $+0.834$

pobremente selecionado assimetria negativa (grosseiros) platicurtico

P1 BW 160-200

intervalo phi -1.00 a 0.00 0.00 a 1.00

1.00 a 2.00

2.00 a 3.00

3.00 a 4.30

Interpretacao do grafico (segundo Folk e Ward, 1957) : media grafica 1.941 desvio padrao 1.185 assimetria curtose valor abs 2.00

3.60

7.80

8.40

5.00 orel \%cum

$7 \begin{array}{ll}7 \\ 13\end{array}$

$13 \quad 21$

$29 \quad 50$

$31 \quad 81$

19100 pobremente selecionado assimetria negativa (grosseiros) mesocurtico 
P1 200-250

intervalo phi

-1.00 a 0.00

0.00 a 1.00

1.00 a 2.00

2.00 a 3.00

valor abs

\%rel ㄷm

2.30

4.00

99

7.80

15

24

7.60

$30 \quad 54$

3.00 a 4.30

4.50

$29 \quad 83$

$17 \quad 100$

Interpretacao do grafico (segundo Folk e Ward, 1957) : media grafica desvio padrao assimetria 1.819 1.224 $-0.084$ pobremente selecionado curtose $+0.995$ aproximadamente simetrica mesocurtico

P1 250-300

intervalo phi -1.00 a 0.00 0.00 a 1.00 valor abs \%rel \%cum 2.00 4.70 $8 \quad 8$

1.00 a 2.00

5.70 $19 \quad 27$

2.00 a 3.00

8.20

$23 \quad 50$

3.00 a 4.30

4.20

$\begin{array}{rr}33 & 83 \\ 17 & 100\end{array}$

Interpretacao do grafico (segundo Folk e Ward, 1957) : media grafica desvio padrao 1.852

1.223 assimetria $-0.165$ curtose $+0.900$

pobremente selecionado assimetria negativa (grosseiros) platicurtico

PI $300-350$

intervalo phi valor abs \%rel cum -1.00 a 0.00 0.00 a 1.00 2.90 $11 \quad 11$ $5.90 \quad 21 \quad 32$

1.00 a 2.00 $5.80 \quad 21 \quad 53$

2.00 a 3.00

8.30

$30 \quad 83$

3.00 a 4.30

4.60

$17 \quad 100$

Interpretacao do grafico (segundo Folk e Ward, 1957) : media grafica desvio padrao 1.735

1.295 assimetria $-0.125$ curtose $+0.847$

pobremente selecionado assimetria negativa (grosseiros) platicurtico 
P1 $350-380$

$\begin{array}{rrrrr}\text { intervalo phi } & \text { valor abs } & \% \text { rel } & \% \text { cum } \\ -1.00 \text { a } & 0.00 & 3.30 & 12 & 12 \\ 0.00 \text { a } & 1.00 & 4.60 & 16 & 28 \\ 1.00 \text { a } & 2.00 & 5.00 & 18 & 46 \\ 2.00 \text { a } & 3.00 & 9.90 & 35 & 81 \\ 3.00 \text { a } & 4.30 & 5.30 & 19 & 100\end{array}$

Interpretacao do grafico (segundo Folk e Ward, 1957) : media grafica 1.838

desvio padrao 1.320 pobremente selecionado assimetria

-0.255 assimetria negativa (grosseiros) curtose +0.863 platicurtico

P1 $380-400$

intervalo phi valor abs \%rel \%cum

-1.00 a 0.00

0.00 a 1.00

4.20

$13 \quad 13$

1.00 a 2.00

5.30

$16 \quad 29$

2.00 a 3.00

8.00

54

3.00 a 4.30

9.50

25

29

5.40

$17 \quad 100$

Interpretacao do grafico (segundo Folk e Ward, 1957) : media grafica 1.704 desvio padrao 1.322 assimetria $-0.133$ curtose

pobremente selecionado assimetria negativa (grosseiros) platicurtico 
yara

Arquivo de entrada SMP2.DAT

Arquivo de saida SMP2. OUT

19-01-1998 $09: 18: 38$

P2 AP $0-20$

$\begin{array}{rrrrr}\text { intervalo phi } & \text { valor abs } & \% \text { rel } & \% \text { cum } \\ 1.00 \mathrm{a} & 0.00 & 4.00 & 8 & 8 \\ 0.00 \mathrm{a} & 1.00 & 9.80 & 20 & 28 \\ 1.00 \mathrm{a} & 2.00 & 13.60 & 28 & 56 \\ 2.00 \mathrm{a} & 3.00 & 13.50 & 28 & 84 \\ 3.00 \mathrm{a} & 4.30 & 7.80 & 16 & 100\end{array}$

Interpretacao do grafico (segundo Folk e Ward, 1957) : media grafica desvio padrao assimetria 1.764

1.137 pobremente selecionado curtose $+0.027$ aproximadamente simetrica +0.799 platicurtico

P2 A2 20-96

$\begin{array}{rrrrr}\text { intervalo phi } & \text { valor abs } & \% \text { rel } & \text { \%cum } \\ 1.00 \text { a } & 0.00 & 3.30 & 12 & 12 \\ 0.00 \text { a } & 1.00 & 5.10 & 18 & 29 \\ 1.00 \text { a } & 2.00 & 4.40 & 15 & 45 \\ 2.00 \text { a } & 3.00 & 9.60 & 34 & 78 \\ 3.00 \text { a } & 4.30 & 6.20 & 22 & 100\end{array}$

Interpretacao do grafico (segundo Folk e Ward, 1957) : media grafica 1.872 desvio padrao 1.227 assimetria $-0.160$ pobremente selecionado curtose $+0.653$ assimetria negativa (grosseiros) muito platicurtico

\section{P2 A3 $95-172$}

$\begin{array}{rrrrr}\text { intervalo phi } & \text { valor abs } & \% \text { rel } & \text { \%cum } \\ 1.00 \text { a } & 0.00 & 3.80 & 11 & 11 \\ 0.00 \text { a } & 1.00 & 8.20 & 23 & 34 \\ 1.00 \text { a } & 2.00 & 6.60 & 19 & 52 \\ 2.00 \text { a } & 3.00 & 11.20 & 32 & 84 \\ 3.00 \text { a } & 4.30 & 5.70 & 16 & 100\end{array}$

Interpretacao do grafico (segundo Folk e Ward, 1957) : media grafica 1.725 desvio padrao 1.172 assimetria curtose

$-0.056$ pobremente selecionado +0.673 platicurtico 


\begin{tabular}{rrrrr}
\multicolumn{1}{l}{ intervalo phi } & valor abs & $\%$ rel & \%cum \\
1.00 a & 0.00 & 3.80 & 10 & 10 \\
0.00 a & 1.00 & 7.60 & 20 & 30 \\
1.00 a & 2.00 & 8.80 & 23 & 54 \\
2.00 a & 3.00 & 11.50 & 31 & 85 \\
3.00 a & 4.30 & 5.80 & 15 & 100
\end{tabular}

Interpretacao do grafico (segundo Folk e Ward, 1957) : media grafica 1.724

desvio padrao 1.139 pobremente selecionado

assimetria $\quad-0.023$

+0.739 platicurtico

P2 BA 212-250

$\begin{array}{rrrrr}\text { intervalo phi } & \text { valor abs } & \text { \%rel } & \text { \%cum } \\ 1.00 \mathrm{a} & 0.00 & 5.20 & 14 & 14 \\ 0.00 \mathrm{a} & 1.00 & 6.90 & 19 & 34 \\ 1.00 \mathrm{a} & 2.00 & 7.80 & 22 & 55 \\ 2.00 \mathrm{a} & 3.00 & 9.80 & 27 & 82 \\ 3.00 \mathrm{a} & 4.30 & 6.40 & 18 & 100\end{array}$

Interpretacao do grafico (segundo Folk e Ward, 1957) : media grafica 1.656 desvio padrao 1.224 assimetria $+0.036$ pobremente selecionado curtose $+0.632$ aproximadamente simetrica muito platicurtico

P2 BW 250-300

$\begin{array}{rrrrr}\text { intervalo phi } & \text { valor abs } & \text { \%rel } & \text { \%cum } \\ 1.00 \text { a } & 0.00 & 5.00 & 15 & 15 \\ 0.00 \text { a } & 1.00 & 6.70 & 20 & 34 \\ 1.00 \text { a } & 2.00 & 8.30 & 24 & 58 \\ 2.00 \text { a } & 3.00 & 8.90 & 26 & 85 \\ 3.00 \text { a } & 4.30 & 5.30 & 15 & 100\end{array}$

Interpretacao do grafico (segundo Folk e Ward, 1957) : media grafica 1.563 desvio padrao 1.197 assimetria $+0.062$ pobremente selecionado curtose $+0.649$ aproximadamente simetrica muito platicurtico 
P2 $300-350$

$\begin{array}{rrrrr}\text { intervalo phi } & \text { valor abs } & \% \text { rel } & \% \text { cum } \\ 1.00 \text { a } & 0.00 & 4.40 & 13 & 13 \\ 0.00 \text { a } & 1.00 & 6.70 & 20 & 32 \\ 1.00 \text { a } & 2.00 & 6.90 & 20 & 52 \\ 2.00 \text { a } & 3.00 & 11.10 & 32 & 85 \\ 3.00 \text { a } & 4.30 & 5.20 & 15 & 100\end{array}$

Interpretacao do grafico (segundo Folk e Ward, 1957) : media grafica desvio padrao 1.687 assimetria

1.171 $-0.080$ pobremente selecionado curtose $+0.670$ aproximadamente simetrica platicurtico

P2 $350-400$

intervalo phi valor abs 1.00 a 0.00 0.00 a 1.00 3.20 \%rel $\div$ cum 6.10 $10 \quad 10$ 1.00 a 2.00 6.90 $18 \quad 28$

2.00 a 3.00

3.00 a 4.30

$\begin{array}{lll}11.70 & 35 & 84\end{array}$

Interpretacao do grafico (segundo Folk e Ward, 1957) : media grafica desvio padrao 1.812

1.145 assimetria $-0.134$ pobremente selecionado curtose $+0.742$ assimetria negativa (grosseiros) platicurtico

P2 $400-450$

intervalo phi 1.00 a 0.00 0.00 a 1.00 1.00 a 2.00 2.00 a 3.00 3.00 a 4.30 valor abs 3.80 6.00 6.40 10.70 7.10 \%rel $\div$ cum $11 \quad 11$

$18 \quad 29$

1948

$31 \quad 79$

$21 \quad 100$

Interpretacao do grafico (segundo Folk e Ward, 1957) : media grafica 1.854

1. 210 assimetria $\quad-0.112$ pobremente selecionado curtose $+0.675$ assimetria negativa (grosseiros) platicurtico 
P2 $450-500$

$\begin{array}{rrrrr}\text { intervalo phi } & \text { valor abs } & \% \text { rel } & \% \text { cum } \\ 1.00 \text { a } & 0.00 & 4.80 & 14 & 14 \\ 0.00 \text { a } & 1.00 & 7.60 & 22 & 35 \\ 1.00 \text { a } & 2.00 & 8.30 & 24 & 59 \\ 2.00 \text { a } & 3.00 & 8.00 & 23 & 82 \\ 3.00 \text { a } & 4.30 & 6.30 & 18 & 100\end{array}$

Interpretacao do grafico (segundo Folk e Ward, 1957) : media grafica 1.608 desvio padrao 1.226 pobremente selecionado assimetria +0.124 assimetria positiva (finos) curtose $+0.639$ muito platicurtico

P2 $500-530$

intervalo phi 1.00 a 0.00

0.00 a 1.00

valor abs :rel $\div$ cum 5.00 7.80 $14 \quad 14$ 1.00 a 2.00 9.30 $21 \quad 35$

2.00 a 3.00

8.60 25

60

3.00 a 4.30

6.00

23

84

Interpretacao do grafico (segundo Folk e Ward, 1957) : media grafica desvio padrao 1.575

1. 201 assimetria $+0.124$ curtose $+0.657$

pobremente selecionado assimetria positiva (finos) muito platicurtico

P2 $530-555$

intervalo phi 1.00 a 0.00 0.00 a 1.00 1.00 a 2.00 2.00 a 3.00 3.00 a 4.30 valor abs 5.80 10.60 7.60 12.80

8.30 orel \%cum

$13 \quad 13$

$24 \quad 36$

$17 \quad 53$

$28 \quad 82$

$18 \quad 100$

Interpretacao do grafico (segundo Folk e Ward, 1957) : media grafica 1.690 desvio padrao 1.217 assimetria $-0.001$ pobremente selecionado curtose $+0.625$ aproximadamente simetrica muito platicurtico 


\begin{tabular}{rrrrr}
\multicolumn{1}{l}{ intervalo phi } & valor abs & \%rel & \%cum \\
1.00 a & 0.00 & 5.90 & 12 & 12 \\
0.00 a & 1.00 & 10.10 & 21 & 33 \\
1.00 a & 2.00 & 10.80 & 22 & 55 \\
2.00 a & 3.00 & 13.00 & 27 & 82 \\
3.00 a & 4.30 & 8.50 & 18 & 100
\end{tabular}

Interpretacao do grafico (segundo Folk e Ward, 1957) : media grafica 1.699

desvio padrao 1.202 pobremente selecionado

assimetria +0.039 aproximadamente simetrica

curtose

+0.665 muito platicurtico

P2 $600-650$

intervalo phi valor abs \%rel \%cum

1.00 a 0.00

5.90

$10 \quad 10$

0.00 a 1.00

15.20

$26 \quad 37$

1.00 a 2.00

13.20

$23 \quad 59$

2.00 a 3.00

3.00 a 4.30

14.40

$25 \quad 84$

$9.00 \quad 16 \quad 100$

Interpretacao do grafico (segundo Folk e Ward, 1957) : media grafica desvio padrao assimetria 1.632 1.173 $+0.142$ curtose

+0.694 platicurtico

pobremente selecionado

assimetria positiva (finos)

P2 $650-690$

intervalo phi 1.00 a 0.00 0.00 a 1.00 1.00 a 2.00 2.00 a 3.00 3.00 a 4.30

Interpretacao do grafico (segundo Folk e Ward, 1957) : media grafica desvio padrao assimetria curtose valor abs

2.10

14.70

19.20

15.70

10.20 ○rel \%cum

$\begin{array}{rr}3 & 3 \\ 24 & 27 \\ 31 & 58 \\ 25 & 84 \\ 16 & 100\end{array}$

1.817

1.098

$+0.088$

$+0.860$ pobremente selecionado

aproximadamente simetrica

platicurtico 
yara

Arquivo de entrada SMP3.DAT

Arquivo de saida SMP3. OUT

19-01-1998 09:23:43

P3 AP $\quad 0-20$

intervalo phi

-1.00 a 0.00

0.00 a 1.00

valor abs \%rel \%cum

1.00 a 2.00

2.00 a 3.00

3.00 a 4.30

2.50

6.50

$\begin{array}{rr}7 & 7 \\ 19 & 26\end{array}$

$6.80 \quad 19 \quad 45$

$11.70 \quad 34 \quad 79$

$\begin{array}{lll}7.40 & 21 & 100\end{array}$

Interpretacao do grafico (segundo Folk e Ward, 1957) : media grafica 1.958 desvio padrao

1.239 assimetria

$-0.199$ curtose

pobremente selecionado

assimetria negativa (grosseiros)

platicurtico

P3 A2 20-68

intervalo phi

-1.00 a 0.00

valor abs

:rel cum

0.00 a 1.00

3.30

99

1.00 a 2.00

6.30

$18 \quad 27$

2.00 a 3.00

9.50

27

54

3.00 a 4.30

9.60

$27 \quad 81$

$\begin{array}{lll}6.80 & 19 \quad 100\end{array}$

Interpretacao do grafico (segundo Folk e Ward, 1957) : media grafica desvio padrao assimetria 1.813

1.263 pobremente selecionado curtose

-0.068 aproximadamente simetrica

+0.899 platicurtico

P3 A3 $68-113$

intervalo phi valor abs \%rel \%cum

-1.00 a 0.00

0.00 a 1.00

3.50

11

11

5.90

$18 \quad 29$

1.00 a 2.00

6.50

$20 \quad 48$

2.00 a 3.00

10.80

$33 \quad 81$

3.00 a 4.30

6.20

19100

Interpretacao do grafico (segundo Folk e Ward, 1957) : media grafica desvio padrao assimetria 1.834

1.307 pobremente selecionado curtose

$-0.218$ $+0.851$ assimetria negativa (grosseiros) platicurtico 


\begin{tabular}{rrrrr}
\multicolumn{1}{l}{ intervalo phi } & valor abs & \%rel & \%cum \\
-1.00 a & 0.00 & 2.40 & 7 & 7 \\
0.00 a & 1.00 & 5.80 & 18 & 25 \\
1.00 a & 2.00 & 6.90 & 21 & 46 \\
2.00 a & 3.00 & 11.30 & 35 & 81 \\
3.00 a & 4.30 & 6.20 & 19 & 100
\end{tabular}

Interpretacao do grafico (segundo Folk e Ward, 1957) : media grafica 1.936 desvio padrao 1.215 pobremente selecionado assimetria $-0.192$ curtose

\section{assimetria negativa (grosseiros)} platicurtico

P3 BA 137-170

intervalo phi -1.00 a 0.00

valor abs \%rel \%cum

0.00 a 1.00

3.00

99

1.00 a 2.00

5.20

$16 \quad 25$

2.00 a 3.00

6.20

1945

3.00 a 4.30

11.70

6.20

$36 \quad 81$

19100

Interpretacao do grafico (segundo Folk e Ward, 1957) : media grafica desvio padrao 1.916

1.252 pobremente selecionado assimetria curtose assimetria negativa (grosseiros) $+0.912$ mesocurtico

\section{P3 BW 170-220}

intervalo phi -1.00 a 0.00 0.00 a 1.00 1.00 a 2.00 valor abs

$$
\text { 1. } 50
$$
\%rel cum

3. 30

2.00 a 3.00

8.30

3.00 a 4.30

11.60

5.70

$\begin{array}{rr}5 & 5 \\ 11 & 16 \\ 27 & 43 \\ 38 & 81 \\ 19 & 100\end{array}$

Interpretacao do grafico (segundo Folk e Ward, 1957) : media grafica desvio padrao 2.091

1.085 pobremente selecionado assimetria $-0.142$ curtose $+1.069$ assimetria negativa (grosseiros) mesocurtico 


$\begin{array}{rrrrr}\text { intervalo phi } & \text { valor abs } & \text { \%rel } & \text { \%cum } \\ -1.00 \text { a } & 0.00 & 2.10 & 7 & 7 \\ 0.00 \text { a } & 1.00 & 6.60 & 22 & 29 \\ 1.00 \text { a } & 2.00 & 7.20 & 24 & 53 \\ 2.00 \text { a } & 3.00 & 8.90 & 30 & 83 \\ 3.00 \text { a } & 4.30 & 5.20 & 17 & 100\end{array}$

Interpretacao do grafico (segundo Folk e Ward, 1957) : media grafica 1.814 desvio padrao assimetria

1.213

$-0.080$ pobremente selecionado curtose $+0.871$ aproximadamente simetrica platicurtico

\section{P3 220-270}

intervalo phi -1.00 a 0.00

0.00 a 1.00

1.00 a 2.00

2.00 a 3.00

3.00 a 4.30 valor abs

2.10

6.60

7.40

8.80

4.80 orel \%cum

$7 \quad 7$

$22 \quad 29$

$25 \quad 54$

$30 \quad 84$

16100

Interpretacao do grafico (segundo Folk e Ward, 1957) : media grafica 1.789 desvio padrao assimetria

1.200 pobremente selecionado curtose $-0.068$ $+0.886$

aproximadamente simetrica platicurtico

P3 $270-320$

intervalo phi

-1.00 a 0.00

0.00 a 1.00

1.00 a 2.00

2.00 a 3.00

3.00 a 4.30

Interpretacao media grafica desvio padrao assimetria curtose

$\begin{array}{rrr}\text { valor abs } & \% \text { rel } & \text { \%cum } \\ 2.20 & 7 & 7 \\ 6.90 & 23 & 30 \\ 7.30 & 24 & 54 \\ 9.00 & 30 & 84 \\ 4.70 & 16 & 100\end{array}$

do grafico (segundo Folk e Ward, 1957) :

1.781

1.204 pobremente selecionado

-0.066 aproximadamente simetrica

+0.873 platicurtico 


\begin{tabular}{rrrrr}
\multicolumn{1}{l}{ intervalo phi } & valor abs & $\%$ rel & \%cum \\
-1.00 a & 0.00 & 2.80 & 9 & 9 \\
0.00 a & 1.00 & 6.70 & 21 & 30 \\
1.00 a & 2.00 & 6.80 & 21 & 51 \\
2.00 a & 3.00 & 9.70 & 30 & 81 \\
3.00 a & 4.30 & 6.20 & 19 & 100
\end{tabular}

Interpretacao do grafico (segundo Folk e Ward, 1957) : media grafica 1.827

desvio padrao 1.276 pobremente selecionado

assimetria $\quad-0.137$

curtose

+0.842 platicurtico

\section{P3 $370-400$}

$\begin{array}{rrrrr}\text { intervalo phi } & \text { valor abs } & \text { orel } & \text { \% cum } \\ -1.00 \text { a } & 0.00 & 2.30 & 7 & 7 \\ 0.00 \text { a } & 1.00 & 7.40 & 24 & 31 \\ 1.00 \text { a } & 2.00 & 8.00 & 26 & 57 \\ 2.00 \text { a } & 3.00 & 8.80 & 28 & 86 \\ 3.00 \text { a } & 4.30 & 4.40 & 14 & 100\end{array}$

Interpretacao do grafico (segundo Folk e Ward, 1957) : media grafica 1.712 desvio padrao assimetria

1.178 pobremente selecionado curtose +0.896 platicurtico

\section{P3 $400-450$}

intervalo phi -1.00 a 0.00 0.00 a 1.00 valor abs \%re1 $\div$ cum 1.00 a 2.00 2.00 a 3.00 3.00 a 4.30

1.60

6.30

6.90

8.40

6.30

$\begin{array}{rr}5 & 5 \\ 21 & 27 \\ 23 & 50 \\ 28 & 79 \\ 21 & 100\end{array}$

Interpretacao do grafico (segundo Folk e Ward, 1957) : media grafica desvio padrao assimetria 1.930

1.196 pobremente selecionado $-0.079$ aproximadamente simetrica curtose 
P3 450-500

\begin{tabular}{rrrrr}
\multicolumn{1}{l}{ intervalo phi } & valor abs & $\%$ rel & \%cum \\
-1.00 a & 0.00 & 1.10 & 3 & 3 \\
0.00 a & 1.00 & 9.10 & 25 & 28 \\
1.00 a & 2.00 & 10.30 & 28 & 56 \\
2.00 a & 3.00 & 9.50 & 26 & 82 \\
3.00 a & 4.30 & 6.50 & 18 & 100
\end{tabular}

Interpretacao do grafico (segundo Folk e Ward, 1957) : media grafica desvio padrao assimetria 1.850

1.127 $+0.073$ pobremente selecionado curtose $+0.815$ aproximadamente simetrica platicurtico

P3 500-535

intervalo phi -1.00 a 0.00 0.00 a 1.00 1.00 a 2.00 2.00 a 3.00 3.00 a 4.30

valor abs

1.30

8.20

9.50

12.90

6.90 rel \%cum

33

$21 \quad 24$

$24 \quad 49$

$33 \quad 82$

18100

Interpretacao do grafico (segundo Folk e Ward, 1957) : media grafica desvio padrao assimetria 1.951

1.106 curtose $-0.075$ pobremente selecionado aproximadamente simetrica platicurtico

\section{P3 $535-580$}

intervalo phi -1.00 a 0.00 0.00 a 1.00 1.00 a 2.00 2.00 a 3.00 3.00 a 4.30 valor abs 1.30

8.00

9.40

12.70

6.70 \%rel :cum

33

$21 \quad 24$

$25 \quad 49$

$33 \quad 82$

18100

Interpretacao do grafico (segundo Folk e Ward, 1957) : media grafica 1.951 desvio padrao 1.106 assimetria $-0.075$ curtose

pobremente selecionado aproximadamente simetrica platicurtico 
P3 $580-600$

$\begin{array}{rrrrr}\text { intervalo phi } & \text { valor abs } & \text { \%rel } & \text { \%cum } \\ -1.00 \text { a } & 0.00 & 0.50 & 1 & 1 \\ 0.00 \text { a } & 1.00 & 8.90 & 22 & 23 \\ 1.00 \text { a } & 2.00 & 9.30 & 23 & 47 \\ 2.00 \text { a } & 3.00 & 13.40 & 33 & 80 \\ 3.00 \text { a } & 4.30 & 7.90 & 20 & 100\end{array}$

Interpretacao do grafico (segundo Folk e Ward, 1957) : media grafica 2.018

desvio padrao 1.070 pobremente selecionado

assimetria

curtose

-0.046 aproximadamente simetrica

+0.780 platicurtico 
yara

Arquivo de entrada SMP4.DAT

Arquivo de saida SMP4.OUT

19-0I-1998 09:25:15

P4 A1 $0-23$

$\begin{array}{rrrrr}\text { intervalo phi } & \text { valor abs } & \% \text { rel } & \text { \%cum } \\ -1.00 \text { a } & 0.00 & 5.30 & 15 & 15 \\ 0.00 \text { a } & 1.00 & 8.60 & 24 & 39 \\ 1.00 \text { a } & 2.00 & 5.30 & 15 & 54 \\ 2.00 \text { a } & 3.00 & 9.30 & 26 & 80 \\ 3.00 \text { a } & 4.30 & 7.20 & 20 & 100\end{array}$

Interpretacao do grafico (segundo Folk e Ward, 1957) : media grafica 1.641

desvio padrao 1.402 pobremente selecionado

assimetria $\quad-0.073$ aproximadamente simetrica

curtose $\quad+0.745$ platicurtico

P4 A2 23-82

intervalo phi valor abs \%rel \%cum

$\begin{array}{rrrrr}-1.00 \mathrm{a} & 0.00 & 5.30 & 13 & 13 \\ 0.00 \mathrm{a} & 1.00 & 7.70 & 19 & 32 \\ 1.00 \mathrm{a} & 2.00 & 6.70 & 17 & 49 \\ 2.00 \mathrm{a} & 3.00 & 14.30 & 35 & 84 \\ 3.00 \mathrm{a} & 4.30 & 6.50 & 16 & 100\end{array}$

Interpretacao do grafico (segundo Folk e Ward, 1957) : media grafica 1.741 desvio padrao 1.316 assimetria curtose

$-0.256$ $+0.834$

pobremente selecionado assimetria negativa (grosseiros) platicurtico

$\mathrm{P} 4 \mathrm{AB} \quad 82-101$

intervalo phi -1.00 a 0.00 0.00 a 1.00 1.00 a 2.00 2.00 a 3.00 3.00 a 4.30

$\begin{array}{rrr}\text { valor abs } & \text { \%rel } & \text { \%cum } \\ 3.50 & 11 & 11 \\ 4.20 & 13 & 24 \\ 5.70 & 18 & 42 \\ 11.50 & 36 & 78 \\ 7.10 & 22 & 100\end{array}$

Interpretacao do grafico (segundo Folk e Ward, 1957) : media grafica 1.946 desvio padrao assimetria 1.308 curtose

pobremente selecionado assimetria negativa (grosseiros) mesocurtico 
P4 BA 101-140

$\begin{array}{rrrrr}\text { intervalo phi } & \text { valor abs } & \text { \%rel } & \text { \%cum } \\ -1.00 \text { a } & 0.00 & 4.40 & 12 & 12 \\ 0.00 \text { a } & 1.00 & 7.70 & 22 & 34 \\ 1.00 \text { a } & 2.00 & 6.80 & 19 & 53 \\ 2.00 \text { a } & 3.00 & 11.60 & 32 & 85 \\ 3.00 \text { a } & 4.30 & 5.30 & 15 & 100\end{array}$

Interpretacao do grafico (segundo Folk e Ward, 1957) : media grafica 1.680

desvio padrao 1.289 pobremente selecionado

$\begin{array}{lll}\text { assimetria } & -0.152 & \text { assimetria negativa (grosseiros) } \\ \text { curtose } & +0.838 & \text { platicurtico }\end{array}$

P4 BW 140-170

intervalo phi -1.00 a 0.00 0.00 a 1.00 1.00 a 2.00 2.00 a 3.00 3.00 a 4.30

valor abs \%rel \%cum $4.00 \quad 11 \quad 11$ $8.90 \quad 25 \quad 36$ $6.70 \quad 19 \quad 54$

$9.80 \quad 27 \quad 82$

$\begin{array}{lll}6.60 & 18 \quad 100\end{array}$

Interpretacao do grafico (segundo Folk e Ward, 1957) : media grafica desvio padrao 1.707

1. 316

pobremente selecionado assimetria

$-0.072$

aproximadamente simetrica curtose

$+0.803$ platicurtico

P4 $170-220$

intervalo phi -1.00 a 0.00 0.00 a 1.00 valor abs \%rel $\%$ cum 3.30 7.70 $10 \quad 10$ 1.00 a 2.00 8.70 $23 \quad 33$

2.00 a 3.00

7.40 26 59

3.00 a 4.30

6.30

22

81

19100

Interpretacao do grafico (segundo Folk e Ward, 1957) : media grafica desvio padrao assimetria 1.702

1. 302 pobremente selecionado curtose $+0.026$ aproximadamente simetrica +0.842 platicurtico 


$\begin{array}{rrrrr}\text { intervalo phi } & \text { valor abs } & \% \text { rel } & \% \text { cum } \\ -1.00 \text { a } & 0.00 & 4.00 & 11 & 11 \\ 0.00 \text { a } & 1.00 & 9.00 & 25 & 36 \\ 1.00 \text { a } & 2.00 & 9.10 & 25 & 61 \\ 2.00 \text { a } & 3.00 & 8.40 & 23 & 84 \\ 3.00 \text { a } & 4.30 & 6.00 & 16 & 100\end{array}$

Interpretacao do grafico (segundo Folk e Ward, 1957) : media grafica 1.609 desvio padrao 1.292 pobremente selecionado assimetria $\quad+0.042$ curtose $+0.859$

aproximadamente simetrica platicurtico

P4 $270-320$

intervalo phi -1.00 a 0.00 0.00 a 1.00 1.00 a 2.00 2.00 a 3.00 3.00 a 4.30

Interpretacao media grafica desvio padrao assimetria curtose

$\begin{array}{rrr}\text { valor abs } & \text { \%rel } & \text { \%cum } \\ 3.40 & 9 & 9 \\ 7.40 & 20 & 30 \\ 8.80 & 24 & 54 \\ 9.70 & 27 & 81 \\ 6.90 & 19 & 100\end{array}$

do grafico (segundo Folk e Ward, 1957) :

1.789

1.276

$-0.065$

$+0.853$ pobremente selecionado

aproximadamente simetrica

platicurtico

P4 $320-370$

\begin{tabular}{rrrrr}
\multicolumn{1}{l}{ intervalo phi } & valor abs & $\%$ rel & \%cum \\
-1.00 a & 0.00 & 2.80 & 8 & 8 \\
0.00 a & 1.00 & 9.80 & 27 & 35 \\
1.00 a & 2.00 & 8.80 & 24 & 59 \\
2.00 a & 3.00 & 8.00 & 22 & 81 \\
3.00 a & 4.30 & 6.90 & 19 & 100
\end{tabular}

Interpretacao do grafico (segundo Folk e Ward, 1957) : media grafica desvio padrao assimetria 1.712

1.274 pobremente selecionado curtose +0.067 aproximadamente simetrica +0.821 platicurtico 


$\begin{array}{rrrrr}\text { intervalo phi } & \text { valor abs } & \% \text { rel } & \% \text { cum } \\ -1.00 \text { a } & 0.00 & 3.50 & 9 & 9 \\ 0.00 \text { a } & 1.00 & 9.20 & 25 & 34 \\ 1.00 \text { a } & 2.00 & 9.00 & 24 & 58 \\ 2.00 \text { a } & 3.00 & 8.80 & 24 & 82 \\ 3.00 \text { a } & 4.30 & 6.70 & 18 & 100\end{array}$

Interpretacao do grafico (segundo Folk e Ward, 1957) : media grafica desvio padrao 1.705

1.279

$+0.022$

pobremente selecionado assimetria $+0.839$

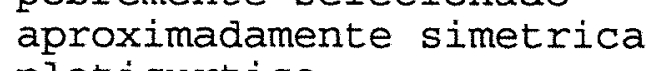
curtose platicurtico

P4 420-470

intervalo phi -1.00 a 0.00 0.00 a 1.00 1.00 a 2.00 2.00 a 3.00 3.00 a 4.30 valor abs 4.20

9.10

9.10

9.00

6.10 orel cum

1111

$24 \quad 35$

$24 \quad 60$

$24 \quad 84$

16100

Interpretacao do grafico (segundo Folk e Ward, 1957) : media grafica desvio padrao assimetria 1.626

1.290 $+0.018$ pobremente selecionado curtose $+0.861$

aproximadamente simetrica

platicurtico

P4 $470 \quad 520$

intervalo phi -1.00 a 0.00 0.00 a 1.00 1.00 a 2.00 2.00 a 3.00 3.00 a 4.30 valor abs \%rel \%cum $3.40 \quad 9 \quad 9$ $9.40 \quad 25 \quad 35$ $10.40 \quad 28 \quad 63$ $8.20 \quad 22 \quad 85$ $\begin{array}{lll}5.50 & 15 & 100\end{array}$

Interpretacao do grafico (segundo Folk e Ward, 1957) : media grafica 1.613 desvio padrao assimetria

1.239 pobremente selecionado curtose $+0.073$ aproximadamente simetrica +0.899 platicurtico 
P4 $520-570$

$\begin{array}{rrrrr}\text { intervalo phi } & \text { valor abs } & \text { \%rel } & \% \text { cum } \\ -1.00 \text { a } & 0.00 & 4.00 & 11 & 11 \\ 0.00 \text { a } & 1.00 & 7.80 & 21 & 32 \\ 1.00 \text { a } & 2.00 & 7.90 & 21 & 53 \\ 2.00 \text { a } & 3.00 & 10.40 & 28 & 81 \\ 3.00 \text { a } & 4.30 & 6.90 & 19 & 100\end{array}$

Interpretacao do grafico (segundo Folk e Ward, 1957) : media grafica 1.757 desvio padrao 1.317 pobremente selecionado $\begin{array}{lll}\text { assimetria } & -0.107 & \text { assimetria negativa } \\ \text { curtose } & +0.826 & \text { platicurtico }\end{array}$

P4 $\quad 570-620$

$\begin{array}{rrrrr}\text { intervalo phi } & \text { valor abs } & \text { orel } & \text { ocum } \\ -1.00 \text { a } & 0.00 & 5.60 & 14 & 14 \\ 0.00 \text { a } & 1.00 & 9.40 & 23 & 37 \\ 1.00 \text { a } & 2.00 & 8.50 & 21 & 58 \\ 2.00 \text { a } & 3.00 & 8.00 & 20 & 78 \\ 3.00 \text { a } & 4.30 & 8.70 & 22 & 100\end{array}$

Interpretacao do grafico (segundo Folk e Ward, 1957) : media grafica desvio padrao assimetria 1.641 1.402 pobremente selecionado curtose $+0.013$ aproximadamente simetrica +0.750 platicurtico

P4 $620-650$

intervalo phi -1.00 a 0.00 0.00 a 1.00 1.00 a 2.00 2.00 a 3.00 3.00 a 4.30 valor abs

$$
4.60
$$$$
10.60
$$$$
10.00
$$$$
7.40
$$

8.00 \%rel \%cum

$11 \quad 11$

$26 \quad 37$

$25 \quad 62$

$18 \quad 80$

$20 \quad 100$

Interpretacao do grafico (segundo Folk e Ward, 1957) : media grafica desvio padrao assimetria 1.638

1.338 $+0.096$ pobremente selecionado curtose $+0.808$ aproximadamente simetrica platicurtico 
yara

Arquivo de entrada SMP5.DAT

Arquivo de saida SMP5. OUT

19-01-1998 09:26:36

P5 A $0-11$

intervalo phi

-1.00 a 0.00

0.00 a 1.00

1.00 a 2.00

valor abs

6.90

re1 $\div$ cum

10.60

15

15

8.30

24

39

2.00 a 3.00

10.70

19

58

3.00 a 4.30

8.30

$\begin{array}{rr}24 & 81 \\ 19 & 100\end{array}$

Interpretacao do grafico (segundo Folk e ward, 1957) :

media grafica

desvio padrao

assimetria

1.580

1.393

pobremente selecionado

curtose

$+0.007$

aproximadamente simetrica

$+0.768$

platicurtico

P5 BA 11-21

intervalo phi

-1.00 a 0.00

0.00 a 1.00

valor abs

\%rel 둥

4.50

$13 \quad 13$

$\begin{array}{lll}5.00 & 14 & 27\end{array}$

1.00 a 2.00

2.00 a 3.00

3.00 a 4.30

6.30

$18 \quad 45$

$11.90 \quad 34 \quad 80$

$\begin{array}{lll}7.10 & 20 \quad 100\end{array}$

Interpretacao do grafico (segundo Folk e Ward, 1957) : media grafica desvio padrao assimetria 1.840

1.346 pobremente selecionado curtose

$-0.271$ assimetria negativa (grosseiros) +0.871 platicurtico

P5 BTI 21-70

intervalo phi -1.00 a 0.00

0.00 a 1.00

1.00 a 2.00

2.00 a 3.00

3.00 a 4.30

valor abs \%rel \%cum 3.70

$12 \quad 12$

$5.40 \quad 18 \quad 30$

$5.10 \quad 17 \quad 46$

$\begin{array}{lll}9.50 & 31 & 77\end{array}$

$\begin{array}{lll}7.00 & 23 & 100\end{array}$

Interpretacao do grafico (segundo Folk e Ward, 1957) : media grafica 1.869 desvio padrao assimetria

1.362

pobremente selecionado curtose

$-0.238$ $+0.790$ assimetria negativa (grosseiros) platicurtico 
P5 BT2 70-

$\begin{array}{rrrrr}\text { intervalo phi } & \text { valor abs } & \text { \%rel } & \text { \%cum } \\ -1.00 \text { a } & 0.00 & 3.90 & 13 & 13 \\ 0.00 \text { a } & 1.00 & 5.80 & 20 & 33 \\ 1.00 \text { a } & 2.00 & 7.20 & 24 & 57 \\ 2.00 \text { a } & 3.00 & 6.90 & 23 & 80 \\ 3.00 \text { a } & 4.30 & 5.80 & 20 & 100\end{array}$

Interpretacao do grafico (segundo Folk e Ward, 1957) : media grafica 1.680 desvio padrao assimetria 1.363 $-0.036$ curtose

+0.811 platicurtico

pobremente selecionado

aproximadamente simetrica 
yara

Arquivo de entrada SMP6.DAT

Arquivo de saida SMP6.OUT

19-01-1998 09:27:38

P6 A $0-9$

intervalo phi

-1.00 a 0.00

0.00 a 1.00

valor abs

3.10

9.70

\%rel \%cum

1.00 a 2.00

14.60

$\begin{array}{rr}6 & 6 \\ 20 & 26\end{array}$

2.00 a 3.00

14.00

$30 \quad 57$

3.00 a 4.30

7.00

$29 \quad 86$

14100

Interpretacao do grafico (segundo Folk e Ward, 1957) : media grafica 1.768 desvio padrao 1.134 assimetria $\quad-0.024$ curtose $+0.958$

pobremente selecionado

aproximadamente simetrica mesocurtico

P6 AB $9-47$

intervalo phi valor abs \%rel \%cum

-1.00 a 0.00

0.00 a 1.00

4.10

$12 \quad 12$

1.00 a 2.00

7.90

$22 \quad 34$

2.00 a 3.00

7.50

21

55

3.00 a 4.30

10.50

$30 \quad 85$

$5.20 \quad 15 \quad 100$

Interpretacao do grafico (segundo Folk e Ward, 1957) : media grafica desvio padrao 1.652

1.288 assimetria $-0.103$ curtose $+0.847$

pobremente selecionado assimetria negativa (grosseiros) platicurtico

P6 BA $47-65$

intervalo phi valor abs \%rel \%cum

-1.00 a 0.00

3.00

$10 \quad 10$

0.00 a 1.00

4.10

1323

1.00 a 2.00

6.90

22

45

2.00 a 3.00

11.50

37

82

3.00 a 4.30

5.70

18100

Interpretacao do grafico (segundo Folk e Ward, 1957) : media grafica desvio padrao 1.908

1.245 assimetria $-0.240$ pobremente selecionado curtose $+0.991$ assimetria negativa (grosseiros) mesocurtico 
P6 BTI 65-104

$\begin{array}{rrrrr}\text { intervalo phi } & \text { valor abs } & \% \text { rel } & \% \text { cum } \\ -1.00 \text { a } & 0.00 & 3.80 & 12 & 12 \\ 0.00 \text { a } & 1.00 & 5.30 & 17 & 29 \\ 1.00 \text { a } & 2.00 & 6.20 & 20 & 49 \\ 2.00 \text { a } & 3.00 & 9.30 & 30 & 79 \\ 3.00 \text { a } & 4.30 & 6.40 & 21 & 100\end{array}$

Interpretacao do grafico (segundo Folk e Ward, 1957) : media grafica desvio padrao 1.827

1.342 pobremente selecionado assimetria $-0.197$ assimetria negativa (grosseiros) curtose +0.831 platicurtico

P6 BT2 104-150

intervalo phi

-1.00 a 0.00

0.00 a 1.00

1.00 a 2.00

2.00 a 3.00

3.00 a 4.30

valor abs 2.30 rel $\div$ cum

4.80

6.90

$15 \quad 22$

11.00

22

34

7.00

Interpretacao do grafico (segundo Folk e Ward, 1957) : media grafica desvio padrao 2.011

1. 221 assimetria $-0.193$ pobremente selecionado curtose $+0.927$ assimetria negativa (grosseiros) mesocurtico 
yara

Arquivo de entrada SMP7.DAT

Arquivo de saida SMP7. OUT

19-01-1998 09:28:12

P7 A $0-20$

intervalo phi valor abs \%rel \%cum

$\begin{array}{rrrrr}-1.00 \text { a } & 0.00 & 4.10 & 11 & 11 \\ 0.00 \text { a } & 1.00 & 4.60 & 12 & 23 \\ 1.00 \text { a } & 2.00 & 8.30 & 22 & 45 \\ 2.00 \text { a } & 3.00 & 14.60 & 39 & 84 \\ 3.00 \mathrm{a} & 4.30 & 5.80 & 16 & 100\end{array}$

Interpretacao do grafico (segundo Folk e Ward, 1957) : media grafica 1.862

desvio padrao 1.240 pobremente selecionado

assimetria

curtose

- 0.269 assimetria negativa (grosseiros)

+1.024 mesocurtico

P7 BA 20-46

intervalo phi valor abs \%rel \%cum

-1.00 a 0.00

0.00 a 1.00

2.60

$10 \quad 10$

1.00 a 2.00

2.90

$11 \quad 21$

2.00 a 3.00

4.40

$17 \quad 39$

3.00 a 4.30

10.90

$43 \quad 81$

$4.80 \quad 19 \quad 100$

Interpretacao do grafico (segundo Folk e Ward, 1957) : media grafica 1.983

desvio padrao 1.237 pobremente selecionado

assimetria $\quad-0.296$

curtose

$+1.052$

assimetria negativa (grosseiros)

mesocurtico

P7 BTI 46-95

$\begin{array}{rrrrr}\text { intervalo phi } & \text { valor abs } & \% \text { rel } & \% \text { cum } \\ -1.00 \text { a } & 0.00 & 3.20 & 10 & 10 \\ 0.00 \text { a } & 1.00 & 3.70 & 12 & 22 \\ 1.00 \text { a } & 2.00 & 7.90 & 25 & 47 \\ 2.00 \text { a } & 3.00 & 10.40 & 33 & 79 \\ 3.00 \text { a } & 4.30 & 6.50 & 21 & 100\end{array}$

Interpretacao do grafico (segundo Folk e Ward, 1957) : media grafica 1.936 desvio padrao assimetria

1.265 pobremente selecionado curtose

$-0.184$ $+0.975$ assimetria negativa (grosseiros) mesocurtico 
P7 BT2 95-160

$\begin{array}{rrrrr}\text { intervalo phi } & \text { valor abs } & \text { \%rel } & \text { \%cum } \\ -1.00 \text { a } & 0.00 & 4.30 & 14 & 14 \\ 0.00 \text { a } & 1.00 & 4.70 & 15 & 30 \\ 1.00 \text { a } & 2.00 & 6.50 & 21 & 51 \\ 2.00 \text { a } & 3.00 & 11.00 & 36 & 87 \\ 3.00 \text { a } & 4.30 & 4.00 & 13 & 100\end{array}$

Interpretacao do grafico (segundo Folk e Ward, 1957) : media grafica 1.663 desvio padrao assimetria

1. 290 $-0.260$ curtose $+0.885$

pobremente selecionado assimetria negativa (grosseiros) platicurtico

P7 $160-210$

intervalo phi

-1.00 a 0.00

0.00 a 1.00

1.00 a 2.00

2.00 a 3.00

3.00 a 4.30

$\begin{array}{rrr}\text { valor abs } & \% \text { rel } & \% \text { cum } \\ 2.70 & 10 & 10 \\ 7.00 & 27 & 37 \\ 5.20 & 20 & 57 \\ 7.20 & 28 & 85 \\ 4.00 & 15 & 100\end{array}$

Interpretacao do grafico (segundo Folk e Ward, 1957) : media grafica desvio padrao assimetria 1.636

1.262

$-0.015$ curtose

pobremente selecionado aproximadamente simetrica platicurtico

\section{P7 $210-260$}

intervalo phi

-1.00 a 0.00

0.00 a 1.00

1.00 a 2.00

2.00 a 3.00

3.00 a 4.30 valor abs 2.60

4.90

7.00

6.20

4.40

$\begin{array}{rr}\circ \text { rel } & \% \text { cum } \\ 10 & 10 \\ 20 & 30 \\ 28 & 58 \\ 25 & 82 \\ 18 & 100\end{array}$

Interpretacao do grafico (segundo Folk e Ward, 1957) : media grafica 1.725 desvio padrao 1.283 pobremente selecionado assimetria $-0.013$ aproximadamente simetrica curtose $+0.886$ platicurtico 


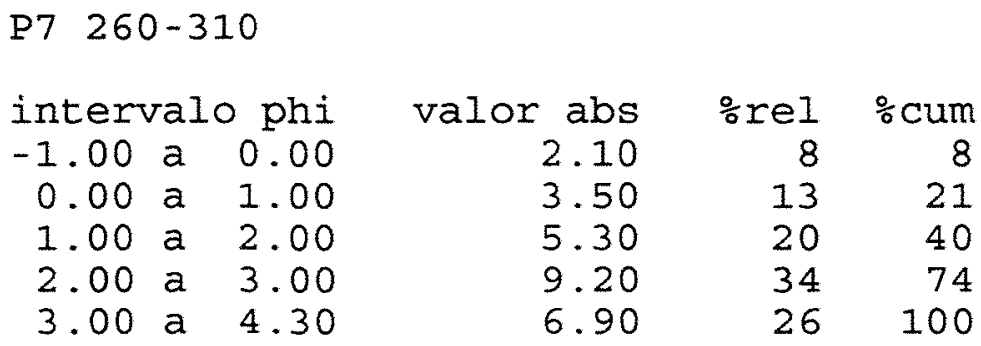

Interpretacao do grafico (segundo Folk e Ward, 1957) : media grafica desvio padrao assimetria curtose 2.080

1.258 pobremente selecionado

-0.248 assimetria negativa (grosseiros) +0.927 mesocurtico

\section{P7 $310-360$ \\ intervalo phi -1.00 a 0.00 0.00 a 1.00 1.00 a 2.00 2.00 a 3.00 3.00 a 4.30}

Interpretacao media grafica desvio padrao assimetria curtose

$\begin{array}{rrr}\text { valor abs } & \text { \%rel } & \% \text { cum } \\ 3.60 & 13 & 13 \\ 4.40 & 16 & 29 \\ 5.50 & 20 & 49 \\ 7.40 & 27 & 76 \\ 6.50 & 24 & 100\end{array}$

do grafico (segundo Folk e Ward, 1957) : 1.832

1.385 pobremente selecionado

-0.191 assimetria negativa (grosseiros)

+0.791 platicurtico

P7 $360-410$

intervalo phi valor abs \%rel \%cum

-1.00 a 0.00 3.10

4.10

11

15

0.00 a 1.00

4.20

16

2.00 a 3.00

8.50

31

7.10

26

11

27

42

3.00 a 4.30

$31 \quad 74$

Interpretacao do grafico (segundo Folk e Ward, 1957) : media grafica 1.963 desvio padrao 1.353 assimetria $-0.274$ pobremente selecionado curtose $+0.802$ assimetria negativa (grosseiros) platicurtico 
intervalo phi -1.00 a 0.00 0.00 a 1.00 1.00 a 2.00 2.00 a 3.00 3.00 a 4.30

Interpretacao media grafica desvio padrao assimetria curtose

$\begin{array}{rrr}\text { valor abs } & \text { \%rel } & \text { \%cum } \\ 4.90 & 15 & 15 \\ 4.40 & 14 & 29 \\ 5.10 & 16 & 45 \\ 10.10 & 32 & 77 \\ 7.50 & 23 & 100\end{array}$

do grafico (segundo Folk e Ward, 1957) : 1.814

1.419 pobremente selecionado

-0.280 assimetria negativa (grosseiros) +0.794 platicurtico

P7 460-510

intervalo phi -1.00 a 0.00 0.00 a 1.00 1.00 a 2.00 2.00 a 3.00 3.00 a 4.30 valor abs 7.40

3.40

4.90

10.10

9.00 rel \%cum

$21 \quad 21$

$10 \quad 31$

$14 \quad 45$

$29 \quad 74$

$26 \quad 100$

Interpretacao do grafico (segundo Folk e Ward, 1957) : media grafica desvio padrao assimetria curtose

1.771

1.504 pobremente selecionado

-0.302 assimetria muito negativa (grosseiros) +0.683 platicurtico

P7 $510-560$

intervalo phi -1.00 a 0.00 0.00 a 1.00 1.00 a 2.00 2.00 a 3.00 3.00 a 4.30 valor abs 2.30

3.20

4.50

9.00

11.10 rel :cum

$8 \quad 8$

$11 \quad 18$

$15 \quad 33$

$30 \quad 63$

$37 \quad 100$

Interpretacao do grafico (segundo Folk e Ward, 1957) : media grafica 2.280 desvio padrao 1.272 assimetria $\quad-0.355$ curtose $+0.983$

pobremente selecionado assimetria muito negativa (grosseiros) mesocurtico 
P7 560-610

$\begin{array}{rrrrr}\text { intervalo phi } & \text { valor abs } & \text { orel } & \text { \% cum } \\ -1.00 \text { a } & 0.00 & 0.50 & 2 & 2 \\ 0.00 \text { a } & 1.00 & 2.00 & 7 & 9 \\ 1.00 \text { a } & 2.00 & 4.80 & 17 & 26 \\ 2.00 \text { a } & 3.00 & 10.30 & 37 & 63 \\ 3.00 \text { a } & 4.30 & 10.50 & 37 & 100\end{array}$

Interpretacao do grafico (segundo Folk e Ward, 1957) : media grafica desvio padrao assimetria 2.529

0.982

$-0.237$ curtose $+1.062$

moderadamente selecionado assimetria negativa (grosseiros) mesocurtico

P7 $610-660$

intervalo phi -1.00 a 0.00 0.00 a 1.00 1.00 a 2.00 2.00 a 3.00 3.00 a 4.30 valor abs 0.20

1.70

5.30

10.30

8.90 rel cum

$\begin{array}{ll}1 & 1 \\ 6 & 7\end{array}$

$20 \quad 27$

$39 \quad 66$

$34 \quad 100$

Interpretacao do grafico (segundo Folk e Ward, 1957) : media grafica 2.517 desvio padrao 0.920 assimetria $-0.158$ curtose $+0.996$

moderadamente selecionado assimetria negativa (grosseiros) mesocurtico 
yara

Arquivo de entrada SMP8.DAT

Arquivo de saida SMP8. OUT

19-01-1998 09:28:52

P8 A $\quad 0-45$

intervalo phi
-1.00 a 0.00

0.00 a 1.00

1.00 a 2.00

2.00 a 3.00

3.00 a 4.30

valor abs \%rel \%cum

$\begin{array}{rrr}3.10 & 7 & 7 \\ 5.40 & 13 & 20 \\ 10.50 & 24 & 44 \\ 14.50 & 34 & 78 \\ 9.40 & 22 & 100\end{array}$

Interpretacao do grafico (segundo Folk e Ward, 1957) : media grafica 2.036

desvio padrao 1.202 pobremente selecionado

assimetria

curtose

$-0.180$

$+0.975$

assimetria negativa (grosseiros)

mesocurtico

P8 $A B \quad 45-62$

intervalo phi valor abs rel \%cum

\begin{tabular}{|c|c|c|c|c|c|}
\hline & & & & & \\
\hline & a & 0.00 & 3.80 & 9 & 9 \\
\hline 0.00 & a & 1.00 & 7.60 & 19 & 28 \\
\hline 1.00 & $\mathrm{a}$ & 2.00 & 10.80 & 27 & 55 \\
\hline 00 & a & 3.00 & 10.60 & 26 & 82 \\
\hline 3.00 & $\mathrm{a}$ & 4.30 & 7.20 & 18 & 100 \\
\hline
\end{tabular}

Interpretacao do grafico (segundo Folk e Ward, 1957) :

media grafica 1.784

desvio padrao 1.258 pobremente selecionado

assimetria $\quad-0.057$ aproximadamente simetrica

curtose $\quad+0.899$ platicurtico

P8 BT $62-90$

intervalo phi

valor abs :rel

-1.00 a 0.00

2.60

8 8 8

0.00 a 1.00

4.80

$15 \quad 23$

1.00 a 2.00

5.80

18

41

2.00 a 3.00

12.20

38

79

3.00 a 4.30

6.70

$21 \quad 100$

Interpretacao do grafico (segundo Folk e Ward, 1957) : media grafica 1.999 desvio padrao assimetria

1.239 pobremente selecionado curtose assimetria negativa (grosseiros) +0.934 mesocurtico 
P8 TRADAGEM 90-100

\begin{tabular}{rrrrr}
\multicolumn{1}{l}{ intervalo phi } & valor abs & \%rel & \%cum \\
-1.00 a & 0.00 & 2.30 & 8 & 8 \\
0.00 a & 1.00 & 4.40 & 15 & 22 \\
1.00 a & 2.00 & 5.40 & 18 & 40 \\
2.00 a & 3.00 & 11.00 & 37 & 77 \\
3.00 a & 4.30 & 6.80 & 23 & 100
\end{tabular}

Interpretacao do grafico (segundo Folk e Ward, 1957) : media grafica 2.037 desvio padrao 1.247 assimetria $-0.256$ curtose +0.940 mesocurtico

pobremente selecionado assimetria negativa (grosseiros) 
$\$$

yara

Arquivo de entrada SMP9.DAT

Arquivo de saida SMP9.OUT

19-01-1998 09:30:08

AP $\quad 0-34$

intervalo phi

-1.00 a 0.00

0.00 a 1.00

valor abs \%rel \%cum

1.00 a 2.00

2.80

9.50

$7 \quad 7$

$11.70 \quad 29 \quad 60$

2.00 a 3.00

11.80

$30 \quad 89$

3.00 a 4.30

4.20

$10 \quad 100$

Interpretacao do grafico (segundo Folk e ward, 1957) : media grafica 1.639

1.128 pobremente selecionado

$\begin{array}{ll}\text { desvio padrao } & 1.128 \\ \text { assimetria } & -0.019\end{array}$

aproximadamente simetrica

curtose

$+0.938$

mesocurtico

A2 $34-65$

intervalo phi

-1.00 a 0.00

valor abs \%rel \%cum

0.00 a 1.00

$1.80 \quad 6 \quad 6$

1.00 a 2.00

$\begin{array}{lll}6.90 & 23 & 29\end{array}$

2.00 a 3.00

$8.00 \quad 26 \quad 55$

3.00 a 4.30

9.70

$32 \quad 87$

$4.00 \quad 13 \quad 100$

Interpretacao do grafico (segundo Folk e Ward, 1957) :

media grafica

1.747

desvio padrao

assimetria

1.135

pobremente selecionado

curtose

$-0.068$

aproximadamente simetrica

mesocurtico

$\mathrm{AB} \quad 65-100$

intervalo phi

$\begin{array}{rrr}\text { valor abs } & \% \text { rel } & \% \text { cum } \\ 1.20 & 4 & 4 \\ 5.20 & 18 & 23 \\ 6.00 & 21 & 44 \\ 11.20 & 40 & 83 \\ 4.70 & 17 & 100\end{array}$

$\begin{array}{lll}0.00 & \text { a } & 1.00 \\ 1.00 & \text { a } & 2.00 \\ 2.00 & \text { a } & 3.00 \\ 3.00 & \text { a } & 4.30\end{array}$

$+0.903$

Interpretacao do grafico (segundo Folk e Ward, 1957) : media grafica desvio padrao assimetria 1.974

1.111 pobremente selecionado curtose

$-0.179$ $+0.889$

assimetria negativa (grosseiros)

platicurtico 
BA $\quad 100-142$

$\begin{array}{rrrrr}\text { intervalo phi } & \text { valor abs } & \text { \%rel } & \text { \% cum } \\ -1.00 \text { a } & 0.00 & 1.60 & 5 & 5 \\ 0.00 \text { a } & 1.00 & 6.00 & 20 & 25 \\ 1.00 \text { a } & 2.00 & 8.30 & 27 & 52 \\ 2.00 \text { a } & 3.00 & 9.80 & 32 & 85 \\ 3.00 \text { a } & 4.30 & 4.60 & 15 & 100\end{array}$

Interpretacao do grafico (segundo Folk e Ward, 1957) : media grafica 1.853

desvio padrao 1.119 pobremente selecionado

assimetria $\quad-0.086$ aproximadamente simetrica

curtose $\quad+0.907$ mesocurtico

BW $142-190+$

intervalo phi

-1.00 a 0.00

0.00 a 1.00

valor abs

1.20

rel $\div$ cum

1.00 a 2.00

4.00

44

2.00 a 3.00

6.60

$14 \quad 19$

3.00 a 4.30

11.70

$24 \quad 43$

$4.20 \quad 15 \quad 100$

Interpretacao do grafico (segundo Folk e Ward, 1957) : media grafica 1.992 desvio padrao 1.054 assimetria $\quad-0.189$ pobremente selecionado curtose $+1.015$ assimetria negativa (grosseiros) mesocurtico 
yara

Arquivo de entrada SMP10.DAT

Arquivo de saida SMP10. OUT

$19-01-1998 \quad 09: 30: 56$

AP $\quad 0-32$

intervalo phi

-1.00 a 0.00

valor abs \%rel \%cum

0.00 a 1.00

2.80

11.70

$6 \quad 6$

1.00 a 2.00

13.00

$25 \quad 32$

2.00 a 3.00

13.60

$28 \quad 60$

3.00 a 4.30

4.90

$30 \quad 89$

11100

Interpretacao do grafico (segundo Folk e ward, 1957) :

media grafica

1.642

desvio padrao

assimetria

1.109

$+0.007$

curtose

$+0.912$

pobremente selecionado

aproximadamente simetrica

mesocurtico

A2 $32-65$

intervalo phi

valor abs \%rel \%cum

0.00 a 1.00

1.40

44

$8.00 \quad 20 \quad 24$

1.00 a 2.00

11.00

$28 \quad 51$

2.00 a 3.00

14.70

$37 \quad 88$

3.00 a 4.30

4.60

12100

Interpretacao do grafico (segundo Folk e Ward, 1957) : media grafica desvio padrao assimetria

1.844

1.049 pobremente selecionado

curtose

$-0.130$

$+0.924$

assimetria negativa (grosseiros)

mesocurtico

\section{A3 $65-117$}

intervalo phi

-1.00 a 0.00

valor abs \%rel \%cum

0.00 a 1.00

1.10

33

$\begin{array}{lll}5.90 & 17 & 20\end{array}$

1.00 a 2.00

9.10

$26 \quad 46$

2.00 a 3.00

12.80

$37 \quad 83$

3.00 a 4.30

5.90

17100

Interpretacao do grafico (segundo Folk e Ward, 1957) : media grafica desvio padrao assimetria 1.995

1.066

$-0.114$

curtose

$+0.931$

pobremente selecionado

assimetria negativa (grosseiros)

mesocurtico 
intervalo phi -1.00 a 0.00 0.00 a 1.00 1.00 a 2.00 2.00 a 3.00 3.00 a 4.30 valor abs

1.10

5.10

7.60

11.00

4.50 orel \%cum

$\begin{array}{rr}4 & 4 \\ 17 & 21 \\ 26 & 47 \\ 38 & 85 \\ 15 & 100\end{array}$

Interpretacao do grafico (segundo Folk e Ward, 1957) : media grafica 1.944 desvio padrao 1.071 pobremente selecionado assimetria curtose $-0.145$ $+0.962$

assimetria negativa (grosseiros) mesocurtico

BA $152-185$

intervalo phi -1.00 a 0.00 0.00 a 1.00 1.00 a 2.00 2.00 a 3.00 3.00 a 4.30 valor abs

1.60

5.30

6.10

12.20

5.10 \%rel \%cum

$\begin{array}{rr}5 & 5 \\ 17 & 23 \\ 20 & 43 \\ 40 & 83 \\ 17 & 100\end{array}$

Interpretacao do grafico (segundo Folk e Ward, 1957) : media grafica 1.971 desvio padrao 1.134 assimetria $-0.210$ curtose $+0.915$

pobremente selecionado assimetria negativa (grosseiros) mesocurtico

BW $185-300$

intervalo phi -1.00 a 0.00 0.00 a 1.00 1.00 a 2.00 2.00 a 3.00 3.00 a 4.30

Interpretacao do grafico (segundo Folk e Ward, 1957) : media grafica desvio padrao assimetria curtose valor abs \%rel \%cum

$\begin{array}{rrr}1.30 & 4 & 4 \\ 5.90 & 20 & 24 \\ 6.80 & 23 & 47 \\ 10.60 & 36 & 83 \\ 5.20 & 17 & 100\end{array}$

\subsection{5}

1.117

$-0.138$

$+0.868$ pobremente selecionado assimetria negativa (grosseiros) platicurtico 
P1 BW 160-200

\begin{tabular}{rrrrr}
\multicolumn{2}{l}{ intervalo phi } & valor abs & \%rel & \%cum \\
-1.00 a & 0.00 & 2.00 & 7 & 7 \\
0.00 a & 1.00 & 3.60 & 13 & 21 \\
1.00 a & 2.00 & 7.80 & 29 & 50 \\
2.00 a & 3.00 & 8.40 & 31 & 81 \\
3.00 a & 4.30 & 5.00 & 19 & 100
\end{tabular}

Interpretacao do grafico (segundo Folk e Ward, 1957) : media grafica desvio padrao assimetria 1.941

1.185

$-0.103$

pobremente selecionado

curtose

$+0.994$

assimetria negativa (grosseiros) mesocurtico

P1 $380-400$

intervalo phi

-1.00 a 0.00

valor abs

단다 cum

0.00 a 1.00

4.20

13

5.30

$16 \quad 29$

1.00 a 2.00

8.00

$25 \quad 54$

2.00 a 3.00

9.50

$29 \quad 83$

3.00 a 4.30

5.40

$17 \quad 100$

Interpretacao do grafico (segundo Folk e Ward, 1957) : media grafica 1.704 desvio padrao 1. 322 pobremente selecionado assimetria $-0.133$ assimetria negativa (grosseiros) curtose +0.889 platicurtico 
yara

Arquivo de entrada SMP11.DAT

Arquivo de saida SMP11. OUT

19-01-1998 09:32:12

P1 AP $0-13$

intervalo phi

-1.00 a 0.00

0.00 a 1.00

valor abs \%rel \%cum

1.00 a 2.00

2.00 a 3.00

3.00 a 4.30

$\begin{array}{rrr}13.40 & 33 & 33 \\ 3.10 & 8 & 41 \\ 4.60 & 11 & 52 \\ 11.50 & 29 & 81 \\ 7.70 & 19 & 100\end{array}$

Interpretacao do grafico (segundo Folk e Ward, 1957) : media grafica 1.543

desvio padrao 1.505

assimetria

curtose

$-0.190$

$+0.616$

pobremente selecionado

assimetria negativa (grosseiros)

muito platicurtico

P1 A2 13-55

intervalo phi

-1.00 a 0.00

0.00 a 1.00

valor abs rel cum

1.00 a 2.00

3.00

6.30

8.00

2.00 a 3.00

11.30

4.10

$\begin{array}{rr}9 & 9 \\ 19 & 28 \\ 24 & 53 \\ 35 & 87 \\ 13 & 100\end{array}$

Interpretacao do grafico (segundo Folk e Ward, 1957) : media grafica 1.739

desvio padrao 1.191

assimetria

$-0.158$

curtose

$+0.939$

pobremente selecionado

assimetria negativa (grosseiros)

mesocurtico

\section{P1 A3 55-96}

intervalo phi

-1.00 a 0.00

0.00 a 1.00

valor abs

rel \%cum

1.00 a 2.00

5.90

20

17

20

5.00

15

37

2.00 a 3.00

10.70

32

52

3.00 a 4.30

5.50

16

84

100

Interpretacao do grafico (segundo Folk e ward, 1957) : media grafica 1.588

desvio padrao assimetria

1.409

$-0.213$

pobremente selecionado

curtose

$+0.734$

assimetria negativa (grosseiros)

platicurtico 
Arquivo de entrada SMP12.DAT

Arquivo de saida SMP12.OUT

19-01-1998 09:35:50

A $\quad 0-16$

$\begin{array}{rrrrr}\text { intervalo phi } & \text { valor abs } & \text { orel } & \text { \%cum } \\ -1.00 \text { a } & 0.00 & 43.30 & 54 & 54 \\ 0.00 \text { a } & 1.00 & 15.80 & 20 & 73 \\ 1.00 \text { a } & 2.00 & 7.30 & 9 & 82 \\ 2.00 \text { a } & 3.00 & 10.30 & 13 & 95 \\ 3.00 \text { a } & 4.30 & 4.10 & 5 & 100\end{array}$

Interpretacao do grafico (segundo Folk e Ward, 1957) : media grafica 0.539 desvio padrao 1.204 pobremente selecionado $\begin{array}{lll}\text { assimetria } & +0.658 & \text { assimetria muito positiva (finos) } \\ \text { curtose } & +1.002 & \text { mesocurtico }\end{array}$

$\mathrm{AB} \quad 16-40$

intervalo phi -1.00 a 0.00 0.00 a 1.00 1.00 a 2.00 2.00 a 3.00 3.00 a 4.30

Interpretacao media grafica desvio padrao assimetria curtose

$\begin{array}{rrr}\text { valor abs } & \% \text { rel } & \% \text { cum } \\ 14.80 & 30 & 30 \\ 15.40 & 31 & 60 \\ 6.30 & 13 & 73 \\ 9.30 & 19 & 92 \\ 4.20 & 8 & 100\end{array}$

do grafico (segundo Folk e Ward, 1957) : 0.965

1.286 pobremente selecionado

+0.332 assimetria muito positiva (finos)

+0.751 platicurtico

BA $\quad 40-80$

intervalo phi -1.00 a 0.00 0.00 a 1.00 1.00 a 2.00 2.00 a 3.00 3.00 a 4.30 valor $a b$

11.70

13.50

7.00

8.50

4.30

$\begin{array}{rr}\% \text { rel } & \% \text { cum } \\ 26 & 26 \\ 30 & 56 \\ 16 & 72 \\ 19 & 90 \\ 10 & 100\end{array}$

Interpretacao do grafico (segundo Folk e Ward, 1957) : media grafica desvio padrao assimetria curtose

1.063

1.313

$+0.289$ $+0.772$ pobremente selecionado assimetria positiva (finos) platicurtico 
BW 80-170+

intervalo phi

-1.00 a 0.00

0.00 a 1.00

1.00 a 2.00

2.00 a 3.00

3.00 a 4.30 valor abs

9.30

11.20

4.60

7.80

3.70 rel \%cum

$25 \quad 25$

$31 \quad 56$

$13 \quad 69$

2190

10100

Interpretacao do grafico (segundo Folk e Ward, 1957) : media grafica 1.086 desvio padrao assimetria

1.319

$+0.295$

pobremente selecionado

curtose

+0.743 platicurtico

assimetria positiva (finos) 
yara

Arquivo de entrada SMP13.DAT

Arquivo de saida SMP13.OUT

19-01-1998 09:36:33

A $\quad 0-10$

intervalo phi

-1.00 a 0.00

0.00 a 1.00

1.00 a 2.00

2.00 a 3.00

valor abs \%rel \%cum

3.00 a 4.30

0.60

1.40

0.80

$5 \quad 5$

$11 \quad 16$

$6 \quad 22$

$\begin{array}{lll}2.00 & 16 & 37\end{array}$

$8.10 \quad 63 \quad 100$

Interpretacao do grafico (segundo Folk e Ward, 1957) : media grafica 2.604

desvio padrao 1.263 pobremente selecionado

assimetria

$-0.614$

curtose

+1.281 leptocurtico

AC $\quad 10-70$

intervalo phi

$\begin{array}{rrr}\text { valor abs } & \text { orel } & \text { \%cum } \\ 0.60 & 4 & 4 \\ 2.50 & 18 & 22 \\ 1.90 & 14 & 36 \\ 3.50 & 25 & 62 \\ 5.30 & 38 & 100\end{array}$

Interpretacao do grafico (segundo Folk e Ward, 1957) : media grafica 2.252

desvio padrao 1.236 pobremente selecionado

assimetria $\quad-0.309$

curtose $\quad+0.769$ platicurtico

pobremente selecionado
assimetria muito negativa (grosseiros) 
yara

Arquivo de entrada SMPEX64.DAT

Arquivo de saida SMPEX64.OUT

19-01-1998 09:37:44

EX64 A $0-20$

intervalo phi valor abs \%rel cum

-1.00 a 0.00

0.00 a 1.00

5.40

5.30

$14 \quad 14$

1.00 a 2.00

11.00

$13 \quad 27$

2.00 a 3.00

12.20

$28 \quad 55$

3.00 a 4.30

5.40

$31 \quad 86$

14100

Interpretacao do grafico (segundo Folk e Ward, 1957) : media grafica 1.641

desvio padrao 1.295 pobremente selecionado

assimetria

curtose

$-0.168$

$+0.972$

assimetria negativa (grosseiros)

mesocurtico

EX64 ABI $20-35$

$\begin{array}{rrrrr}\text { intervalo phi } & \text { valor abs } & \text { \%rel } & \text { \%cum } \\ -1.00 \text { a } & 0.00 & 3.70 & 10 & 10 \\ 0.00 \text { a } & 1.00 & 5.80 & 15 & 25 \\ 1.00 \text { a } & 2.00 & 8.30 & 22 & 47 \\ 2.00 \text { a } & 3.00 & 12.30 & 32 & 79 \\ 3.00 \text { a } & 4.30 & 8.10 & 21 & 100\end{array}$

Interpretacao do grafico (segundo Folk e Ward, 1957) : media grafica 1.906

desvio padrao 1.288 pobremente selecionado

assimetria $\quad-0.198$

curtose +0.901

assimetria negativa (grosseiros)

mesocurtico

EX64 AB2 $35-60$

$\begin{array}{rrrrr}\text { intervalo phi } & \text { valor abs } & \text { \%rel } & \text { \%cum } \\ -1.00 \text { a } & 0.00 & 3.50 & 10 & 10 \\ 0.00 \text { a } & 1.00 & 6.50 & 19 & 30 \\ 1.00 \text { a } & 2.00 & 7.90 & 24 & 54 \\ 2.00 \text { a } & 3.00 & 10.50 & 31 & 85 \\ 3.00 \text { a } & 4.30 & 5.00 & 15 & 100\end{array}$

Interpretacao do grafico (segundo Folk e Ward, 1957) : media grafica 1.724 desvio padrao 1.244 assimetria $\quad-0.119$ curtose

$+0.897$

pobremente selecionado

assimetria negativa (grosseiros) platicurtico 
EX64 BA $60-105$

$\begin{array}{rrrrr}\text { intervalo phi } & \text { valor abs } & \% \text { rel } & \text { \% cum } \\ -1.00 \text { a } & 0.00 & 6.00 & 19 & 19 \\ 0.00 \text { a } & 1.00 & 6.30 & 20 & 38 \\ 1.00 \text { a } & 2.00 & 4.80 & 15 & 53 \\ 2.00 \text { a } & 3.00 & 10.20 & 32 & 85 \\ 3.00 \text { a } & 4.30 & 5.00 & 15 & 100\end{array}$

Interpretacao do grafico (segundo Folk e ward, 1957) : media grafica desvio padrao 1.560 assimetria

1. 387

$-0.183$

pobremente selecionado curtose $+0.749$ assimetria negativa (grosseiros) platicurtico

EX64 BW1 105-165

intervalo phi -1.00 a 0.00 0.00 a 1.00 1.00 a 2.00 2.00 a 3.00 3.00 a 4.30

Interpretacao media grafica desvio padrao assimetria curtose valor abs 4.20 4.60 5.00

9.60 5.50 \%rel \%cum $15 \quad 15$ $16 \quad 30$

$17 \quad 48$

$33 \quad 81$

19100

do grafico (segundo Folk e Ward, 1957) :

1.747

1.386

$-0.259$

$+0.823$ pobremente selecionado assimetria negativa (grosseiros) platicurtico

EX64 BW2 105-200+

intervalo phi -1.00 a 0.00 0.00 a 1.00 1.00 a 2.00 2.00 a 3.00 3.00 a 4.30 valor abs \%rel cum $3.30 \quad 12 \quad 12$

$3.70 \quad 13 \quad 24$

$5.60 \quad 20 \quad 44$

$8.90 \quad 31 \quad 75$

$\begin{array}{lll}7.10 & 25 & 100\end{array}$

Interpretacao do grafico (segundo Folk e Ward, 1957) : media grafica 1.940 desvio padrao 1.349 assimetria $-0.248$ pobremente selecionado curtose $+0.880$ assimetria negativa (grosseiros) platicurtico 
yara

Arquivo de entrada SMPEX65.DAT

Arquivo de saida SMPEX65. OUT

19-01-1998 09:38:14

A $\quad 0-48$

intervalo phi valor abs \%rel \%cum

$\begin{array}{rrrrr}-1.00 \text { a } & 0.00 & 2.20 & 5 & 5 \\ 0.00 \text { a } & 1.00 & 10.70 & 24 & 29 \\ 1.00 \text { a } & 2.00 & 14.40 & 32 & 61 \\ 2.00 \text { a } & 3.00 & 12.20 & 27 & 89 \\ 3.00 \mathrm{a} & 4.30 & 4.90 & 11 & 100\end{array}$

Interpretacao do grafico (segundo Folk e Ward, 1957) :

media grafica 1.672

desvio padrao 1.070 pobremente selecionado

assimetria $\quad+0.029$ aproximadamente simetrica

curtose +0.937 mesocurtico

$\mathrm{ABI} \quad 48-66$

$\begin{array}{rrrrr}\text { intervalo phi } & \text { valor abs } & \text { orel } & \text { \%cum } \\ -1.00 \text { a } & 0.00 & 5.60 & 14 & 14 \\ 0.00 \text { a } & 1.00 & 10.80 & 28 & 42 \\ 1.00 \text { a } & 2.00 & 8.80 & 22 & 64 \\ 2.00 \text { a } & 3.00 & 9.50 & 24 & 89 \\ 3.00 \text { a } & 4.30 & 4.50 & 11 & 100\end{array}$

Interpretacao do grafico (segundo Folk e Ward, 1957) : media grafica 1.397

desvio padrao 1.257 pobremente selecionado

assimetria +0.061 aproximadamente simetrica

curtose $\quad+0.851$ platicurtico

BA $\quad 66-75$

intervalo phi

-1.00 a 0.00

valor abs

\%rel \%cum

4.30

$11 \quad 11$

0.00 a 1.00

9.30

$25 \quad 36$

1.00 a 2.00

9.30

2560

2.00 a 3.00

10.10

27

87

3.00 a 4.30

4.90

13100

Interpretacao do grafico (segundo Folk e Ward, 1957) : media grafica 1.567 desvio padrao

1.243 pobremente selecionado assimetria

$-0.010$ aproximadamente simetrica curtose $+0.875$ platicurtico 
$2 \mathrm{~A} \quad 75-87$

intervalo phi

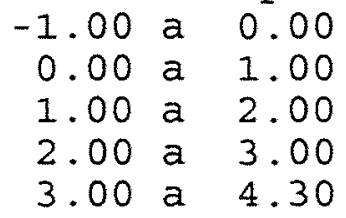

valor abs \%rel \%cum

$\begin{array}{rrr}3.40 & 9 & 9 \\ 11.60 & 30 & 39 \\ 9.00 & 23 & 62 \\ 9.40 & 24 & 87 \\ 5.00 & 13 & 100\end{array}$

Interpretacao do grafico (segundo Folk e Ward, 1957) : media grafica 1.547 desvio padrao assimetria

1.215 pobremente selecionado curtose +0.081 aproximadamente simetrica +0.871 platicurtico

BW $\quad 87-120$

intervalo phi -1.00 a 0.00 0.00 a 1.00 1.00 a 2.00 valor abs rel cum

$\begin{array}{rrr}5.10 & 14 & 14 \\ 10.30 & 29 & 43 \\ 7.60 & 21 & 64 \\ 8.40 & 23 & 87 \\ 4.70 & 13 & 100\end{array}$

Interpretacao do grafico (segundo Folk e Ward, 1957) : media grafica 1.418 desvio padrao 1.292 pobremente selecionado assimetria +0.104 assimetria positiva (finos) curtose $+0.839$ platicurtico 
Arquivo de entrada FALHA.DAT

Arquivo de saida FALHA. OUT

19-01-1998 09:39:23

\section{ESPELHO DE FALHA}

$\begin{array}{rrrrr}\text { intervalo phi } & \text { valor abs } & \text { \%rel } & \text { ocum } \\ -1.00 \text { a } & 0.00 & 0.70 & 2 & 2 \\ 0.00 \text { a } & 1.00 & 5.20 & 16 & 18 \\ 1.00 \text { a } & 2.00 & 7.80 & 24 & 41 \\ 2.00 \text { a } & 3.00 & 9.30 & 28 & 69 \\ 3.00 \text { a } & 4.30 & 10.10 & 31 & 100\end{array}$

Interpretacao do grafico (segundo Folk e Ward, 1957) : media grafica 2.199

desvio padrao 1.130 pobremente selecionado

$\begin{array}{lll}\text { assimetria } & -0.136 & \text { assimetria negativa (grosseiros) }\end{array}$

curtose $\quad+0.798$ platicurtico

\section{MATERIAL ADJACENTE A FALHA}

$\begin{array}{rrrrr}\text { intervalo phi } & \text { valor abs } & \% \text { rel } & \text { \%cum } \\ -1.00 \mathrm{a} & 0.00 & 0.40 & 1 & 1 \\ 0.00 \mathrm{a} & 1.00 & 6.70 & 17 & 18 \\ 1.00 \mathrm{a} & 2.00 & 10.30 & 25 & 43 \\ 2.00 \mathrm{a} & 3.00 & 10.80 & 27 & 70 \\ 3.00 \mathrm{a} & 4.30 & 12.30 & 30 & 100\end{array}$

Interpretacao do grafico (segundo Folk e Ward, 1957) : media grafica 2.178

desvio padrao 1.103 pobremente selecionado

$\begin{array}{lll}\text { assimetria } & -0.078 & \text { aproximadamente simetrica } \\ \text { curtose } & +0.765 & \text { platicurtico }\end{array}$ 